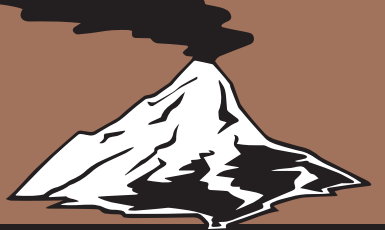

\title{
Geologic Field-Trip Guide to Long Valley Caldera, California
}

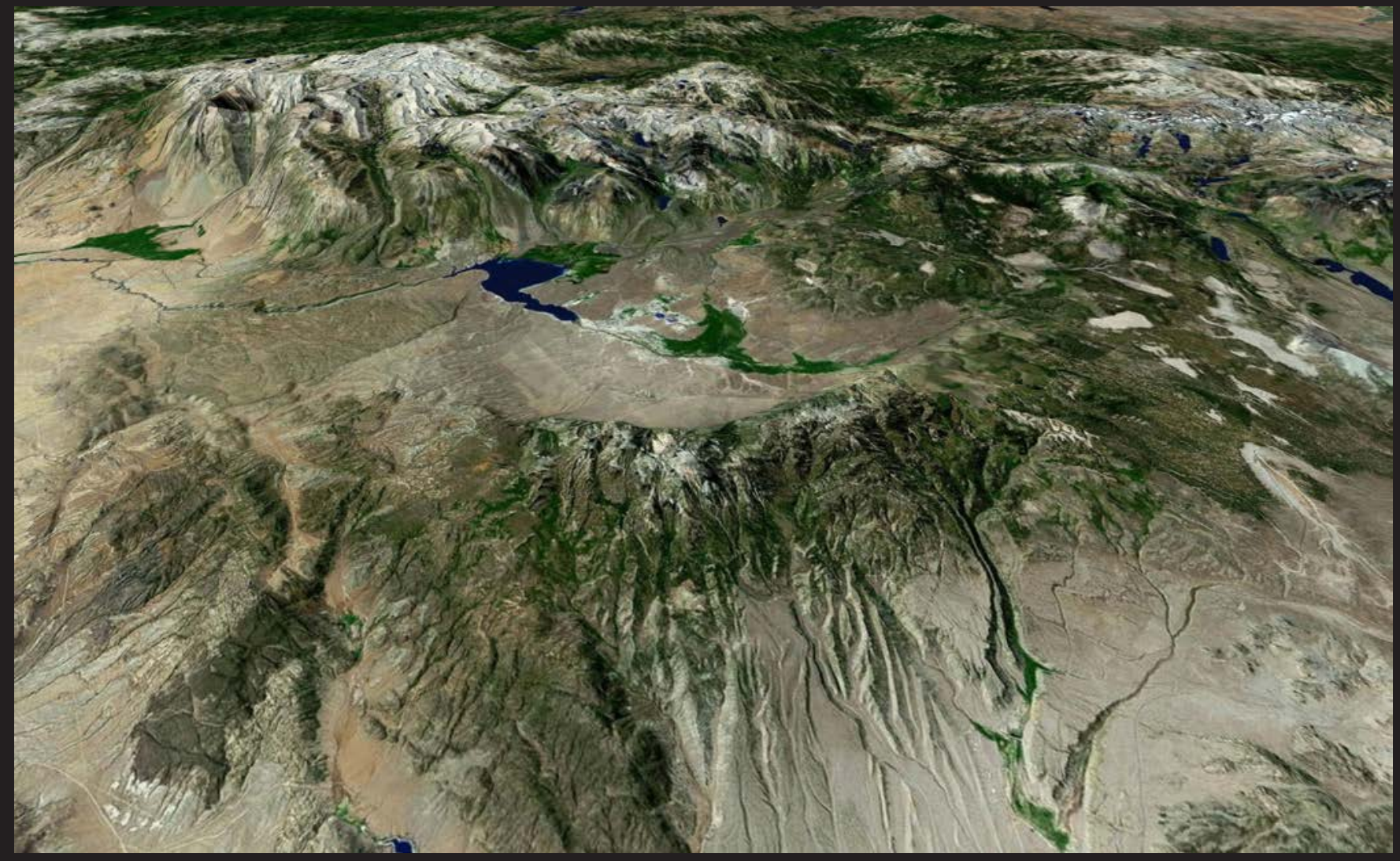

Scientific Investigations Report 2017-5022-L 
COVER

View southwestward across Long Valley Caldera and Sierra Nevada. Caldera depression, as wide as $30 \mathrm{~km}$, formed during eruption of Bishop Tuff at $767 \mathrm{ka}$. Sierra consists of Mesozoic plutonic rocks, Mesozoic metavolcanic rocks, and Paleozoic marine metasedimentary strata. Patchy white exposures in caldera are lacustrine siltstones of middle Pleistocene age that are the top of a 700-m-thick accumulation of intracaldera lake sediment. Sedimentation in the deep closed depression took 600,000 years to raise lake level to its threshold for overflow around $150 \mathrm{ka}$. Outlet arm of Lake Crowley reservoir leads into Owens River Gorge, which extends 30 $\mathrm{km}$ southeast across a welded Bishop Tuff outflow sheet. Overflow and draining of the caldera lake reincised a 200-m-deep precaldera gorge (in Mesozoic granodiorite) that had been diverted by 3.3-Ma basalt and later blanketed by the Bishop Tuff. Round Valley Fault is 2-km-high east-facing scarp at left. At lower center of image, precaldera Glass Mountain rhyolite edifice was truncated by caldera collapse and draped by complexly incised apron of Bishop Tuff. Photo is a NaturalVue satellite image mosaic, which has been extracted from a global dataset of natural-color Landsat-7 multispectral images compiled by MDA Information Systems, Inc. Cover image produced and processed by Joel E. Robinson. Imagery copyright 2010, MDA Information Systems, USGS, NASA. 


\section{Geologic Field-Trip Guide to Long Valley Caldera, California}

By Wes Hildreth and Judy Fierstein

With sections on

A Refreshing Overview of the Bishop Tuff

By Wes Hildreth

Concealed Ring-Fault Zone of Long Valley Caldera

By Wes Hildreth

Overview of the Long Valley Hydrothermal System After Decades of

Study

By William C. Evans

Scientific Investigations Report 2017-5022-L 


\title{
U.S. Department of the Interior RYAN K. ZINKE, Secretary
}

\section{U.S. Geological Survey William H. Werkheiser, Acting Director}

\author{
U.S. Geological Survey, Reston, Virginia: 2017
}

For more information on the USGS - the Federal source for science about the Earth, its natural and living resources, natural hazards, and the environment-visit http://www.usgs.gov or call 1-888-ASK-USGS.

For an overview of USGS information products, including maps, imagery, and publications, visit http://store.usgs.gov.

Any use of trade, firm, or product names is for descriptive purposes only and does not imply endorsement by the U.S. Government.

Although this information product, for the most part, is in the public domain, it also may contain copyrighted materials as noted in the text. Permission to reproduce copyrighted items must be secured from the copyright owner.

Suggested citation:

Hildreth, W. and Fierstein, J., 2017, Geologic field-trip guide to Long Valley Caldera, California: U.S. Geological Survey Scientific Investigations Report 2017-5022-L, 119 p., https://doi.org/10.3133/sir20175120L.

ISSN 2328-0328 (online) 


\section{Preface}

The North American Cordillera is home to a greater diversity of volcanic provinces than any comparably sized region in the world. The interplay between changing plate-margin interactions, tectonic complexity, intra-crustal magma differentiation, and mantle melting have resulted in a wealth of volcanic landscapes. Field trips in this series visit many of these landscapes, including (1) active subduction-related arc volcanoes in the Cascade Range; (2) flood basalts of the Columbia Plateau; (3) bimodal volcanism of the Snake River Plain-Yellowstone volcanic system; (4) some of the world's largest known ignimbrites from southern Utah, central Colorado, and northern Nevada; (5) extension-related volcanism in the Rio Grande Rift and Basin and Range Province; and (6) the spectacular eastern Sierra Nevada featuring Long Valley Caldera and the iconic Bishop Tuff. Some of the field trips focus on volcanic eruptive and emplacement processes, calling attention to the fact that the western United States provides opportunities to examine a wide range of volcanological phenomena at many scales.

The 2017 Scientific Assembly of the International Association of Volcanology and Chemistry of the Earth's Interior (IAVCEI) in Portland, Oregon, marks the first time that the U.S. volcanological community has hosted this quadrennial meeting since 1989, when it was held in Santa Fe, New Mexico. The 1989 field-trip guides are still widely used by students and professionals alike. This new set of field guides is similarly a legacy collection that summarizes decades of advances in our understanding of magmatic and tectonic processes of volcanic western North America.

The field of volcanology has flourished since the 1989 IAVCEI meeting, and it has profited from detailed field investigations coupled with emerging new analytical methods. Mapping has been enhanced by plentiful major- and trace-element whole-rock and mineral data, technical advances in radiometric dating and collection of isotopic data, GPS (Global Positioning System) advances, and the availability of lidar (light detection and ranging) imagery. Spectacularly effective microbeam instruments, geodetic and geophysical data collection and processing, paleomagnetic determinations, and modeling capabilities have combined with mapping to provide new information and insights over the past 30 years. The collective works of the international community have made it possible to prepare wholly new guides to areas across the western United States. These comprehensive field guides are available, in large part, because of enormous contributions from many experienced geologists who have devoted entire careers to their field areas. Early career scientists are carrying forward and refining their foundational work with impressive results.

Our hope is that future generations of scientists as well as the general public will use these field guides as introductions to these fascinating areas and will be enticed toward further exploration and field-based research.

Michael Dungan, University of Oregon Judy Fierstein, U.S. Geological Survey Cynthia Gardner, U.S. Geological Survey Dennis Geist, National Science Foundation Anita Grunder, Oregon State University John Wolff, Washington State University

Field-trip committee, IAVCEI 2017 


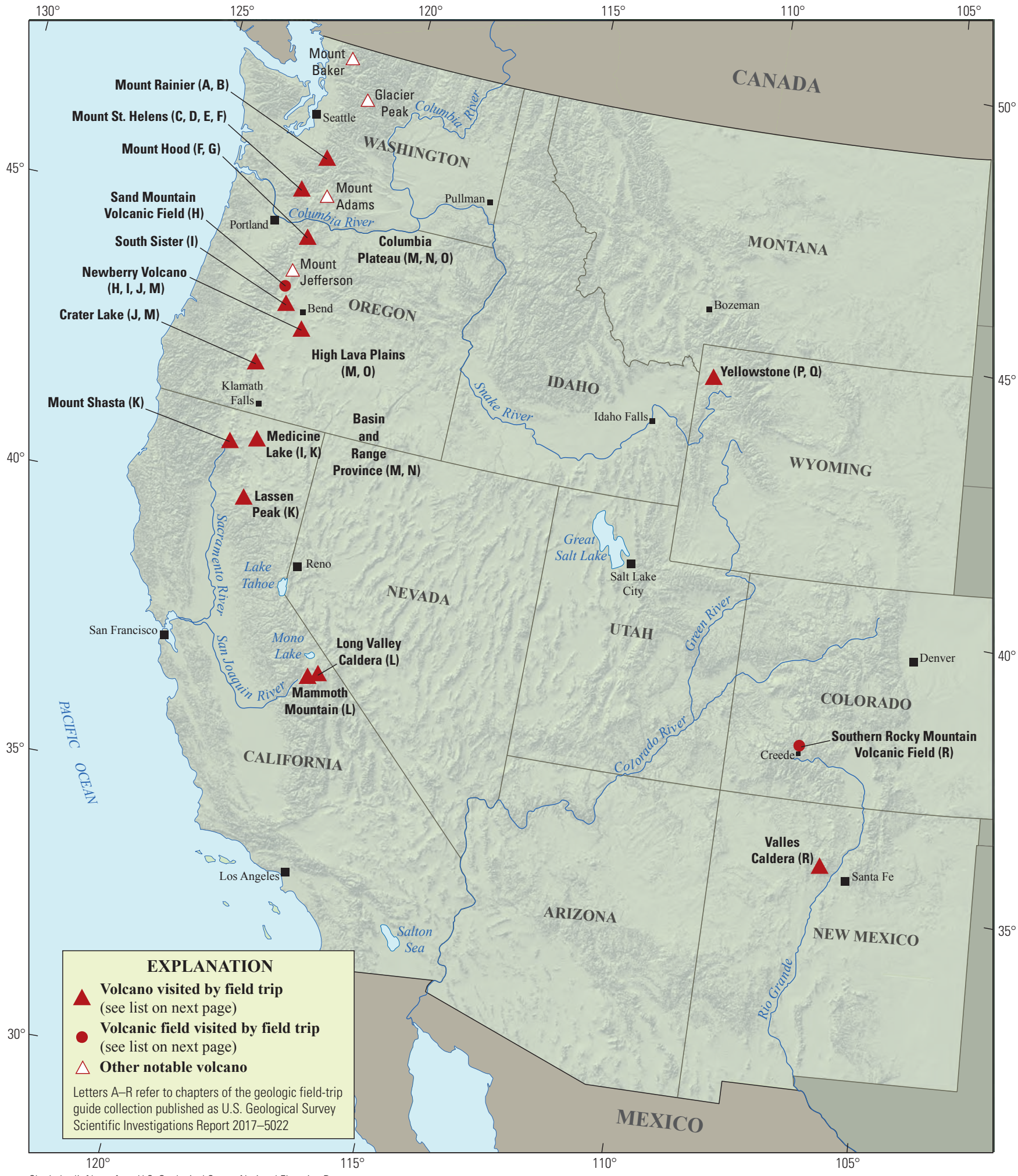

Shaded-relief base from U.S. Geological Survey National Elevation Dataset

30-meter digital elevation model data

Map of the western United States showing volcanoes and volcanic fields visited by geologic field trips scheduled in conjunction with the 2017 meeting of the International Association of Volcanology and Chemistry of the Earth's Interior (IAVCEI) in Portland, Oregon, and available as chapters in U.S. Geological Survey Scientific Investigations

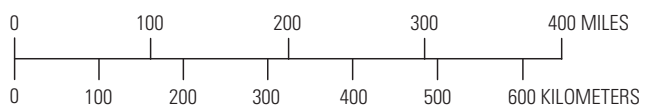
Report 2017-5022. 


\section{Chapter \\ letter Title}

A

B

C

D

E

F

G

H

I

J

K

$\mathrm{L}$

M

$\mathrm{N}$

0

P

0

R
Field-Trip Guide to Volcanism and Its Interaction with Snow and Ice at Mount Rainier, Washington

Field-Trip Guide to Subaqueous Volcaniclastic Facies in the Ancestral Cascades Arc in Southern Washington State-The Ohanapecosh Formation and Wildcat Creek Beds

Field-Trip Guide for Exploring Pyroclastic Density Current Deposits from the May 18, 1980, Eruption of Mount St. Helens, Washington

Field-Trip Guide to Mount St. Helens, Washington-An overview of the Eruptive History and Petrology, Tephra Deposits, 1980 Pyroclastic Density Current Deposits, and the Crater

Field-Trip Guide to Mount St. Helens, Washington-Recent and Ancient Volcaniclastic Processes and Deposits

Geologic Field-Trip Guide of Volcaniclastic Sediments from Snow- and Ice-Capped Volcanoes-Mount St. Helens, Washington, and Mount Hood, Oregon

Field-Trip Guide to Mount Hood, Oregon, Highlighting Eruptive History and Hazards

Field-Trip Guide to Mafic Volcanism of the Cascade Range in Central Oregon-A Volcanic, Tectonic, Hydrologic, and Geomorphic Journey

Field-Trip Guide to Holocene Silicic Lava Flows and Domes at Newberry Volcano, Oregon, South Sister Volcano, Oregon, and Medicine Lake Volcano, California

Geologic Field-Trip Guide to Mount Mazama, Crater Lake Caldera, and Newberry Volcano, Oregon

Geologic Field-Trip Guide to Volcanoes of the Cascades Arc in Northern California

Geologic Field-Trip Guide to Long Valley Caldera, California

Field-Trip Guide to a Volcanic Transect of the Pacific Northwest

Field-Trip Guide to the Vents, Dikes, Stratigraphy, and Structure of the Columbia River Basalt Group, Eastern Oregon and Southeastern Washington

Field-Trip Guide to Flood Basalts, Associated Rhyolites, and Diverse Post-Plume Volcanism in Eastern Oregon

Field-Trip Guide to the Volcanic and Hydrothermal Landscape of Yellowstone Plateau, Montana and Wyoming

Field-Trip Guide to the Petrology of Quaternary Volcanism on the Yellowstone Plateau, Idaho and Wyoming

Field-Trip Guide to Continental Arc to Rift Volcanism of the Southern Rocky Mountains-Southern Rocky Mountain, Taos Plateau, and Jemez Volcanic Fields of Southern Colorado and Northern New Mexico 


\section{Contributing Authors}

Boise State University
Brittany D. Brand
Nicholas Pollock
Colgate University
Karen Harpp
Alison Koleszar
Durham University
Richard J. Brown
Eastern Oregon University
Mark L. Ferns
ETH Zurich
Olivier Bachmann
Georgia Institute of
Technology
Josef Dufek
GNS Science, New
Zealand
Natalia I. Deligne
Hamilton College
Richard M. Conrey

Massachusetts Institute of Technology Timothy Grove

National Science

Foundation

Dennis Geist (also with

Colgate University and University of Idaho)

New Mexico Bureau of Geology and Mineral Resources

Paul W. Bauer

William C. McIntosh

Matthew J. Zimmerer

New Mexico State

University

Emily R. Johnson

Northeastern University

Martin E. Ross

Oregon Department of Geology and Mineral Industries

William J. Burns

Lina $\mathrm{Ma}$

Ian P. Madin

Jason D. McClaughry

Oregon State University

Adam J.R. Kent
Portland State University

Jonathan H. Fink (also

with University of British

Columbia)

Martin J. Streck

Ashley R. Streig

San Diego State University

Victor E. Camp

Smithsonian Institution

Lee Siebert

Universidad Nacional Autónoma

de San Luis Potosi

Damiano Sarocchi

University of California, Davis

Kari M. Cooper

University of Liverpool

Peter B. Kokelaar

University of Northern Colorado

Steven W. Anderson

University of Oregon

Ilya N. Binderman

Michael A. Dungan

Daniele McKay (also with Oregon

State University and Oregon

State University, Cascades)

University of Portland

Kristin Sweeney

University of Tasmania

Martin Jutzeler

Jocelyn McPhie

University of Utah

Jamie Farrell

U.S. Army Corps of

Engineers

Keith I. Kelson

\section{U.S. Forest Service}

Gordon E. Grant (also with

Oregon State University

Robert A. Jensen

U.S. Geological Survey

Charles R. Bacon

Andrew T. Calvert

Christine F. Chan

Robert L. Christiansen

Michael A. Clynne

Michael A. Cosca

Julie M. Donnelly-Nolan
Benjamin J. Drenth William C. Evans

Judy Fierstein

Cynthia A. Gardner

V.J.S. Grauch

Christopher J. Harpel

Wes Hildreth

Richard P. Hoblitt

Peter W. Lipman

Jacob B. Lowenstern

Jon J. Major

Seth C. Moran

Lisa A. Morgan

Leah E. Morgan

L.J. Patrick Muffler

James E. O'Connor

John S. Pallister

Thomas C. Pierson

Joel E. Robinson

Juliet Ryan-Davis

Kevin M. Scott

William E. Scott

Wayne (Pat) Shanks

David R. Sherrod

Thomas W. Sisson

Mark Evan Stelten

Weston Thelen

Ren A. Thompson

Kenzie J. Turner

James W. Vallance

Alexa R. Van Eaton

Jorge A. Vazquez

Richard B. Waitt

Heather M. Wright

U.S. Nuclear Regulatory

Commission

Stephen Self (also with University of California, Berkeley)

Washington State University Joseph R. Boro

Owen K. Neill

Stephen P. Reidel

John A. Wolff

\section{Acknowledgments}

Juliet Ryan-Davis and Kate Sullivan created the overview map, and Vivian Nguyen created the cover design for this collection of field-trip guide books. The field trip committee is grateful for their contributions. 


\section{Contents}

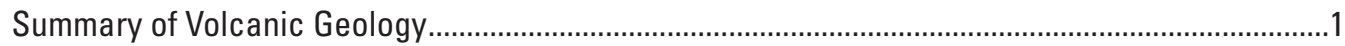

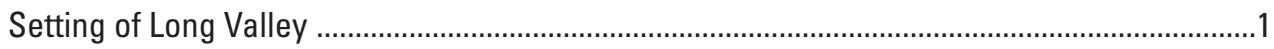

Precaldera Eruptions of Basalt to Dacite (4.0-2.6 Ma) ......................................................

Precaldera Eruptions of Glass Mountain Rhyolite (2.2-0.8 Ma) …........................................

Climactic Eruption and Caldera Formation ...........................................................................

Early Postcaldera Rhyolite (ER) .......................................................................................

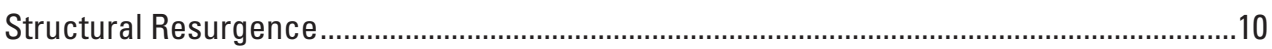

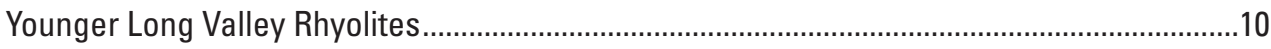

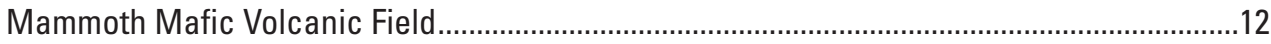

Mammoth Mountain Trachydacite Edifice ………..............................................................14

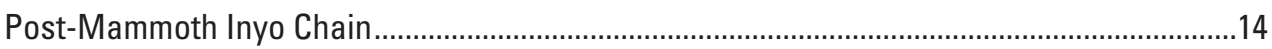

Long Valley Chronology: A Summary Timeline .....................................................................18

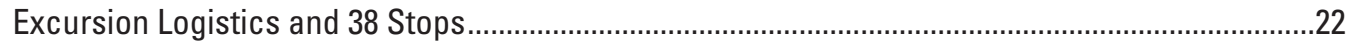

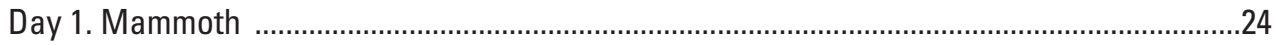

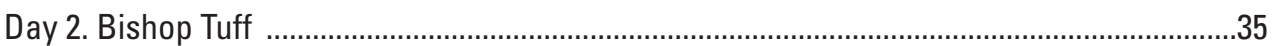

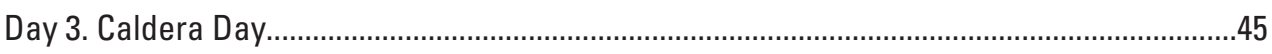

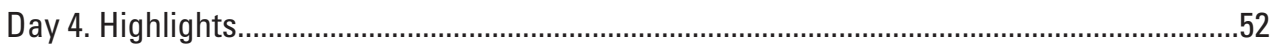

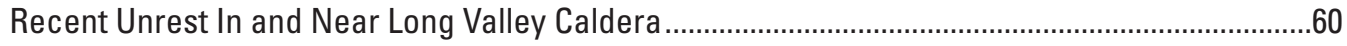

Long Valley Geophysical Puzzles .............................................................................................

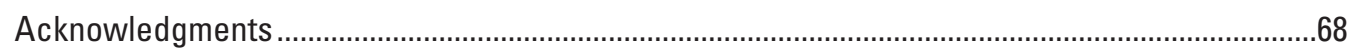

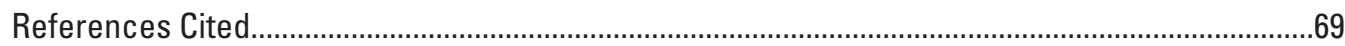

\section{Sections}

A Refreshing Overview of the Bishop Tuff

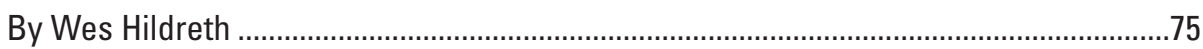

Concealed Ring-Fault Zone of Long Valley Caldera

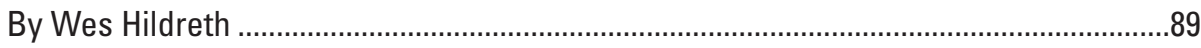

Overview of the Long Valley Hydrothermal System After Decades of Study

By Williams C. Evans. 


\section{Figures}

1. Shaded relief map of Long Valley Caldera region at western limit of Basin and Range Province

2. Regional location map indicating many geographic features mentioned in text........................

3. Precaldera volcanic vents and main Basin and Range extensional faults peripheral to later site of Long Valley Caldera.

4. Glass Mountain rhyolite dome field on northeast wall of Long Valley Caldera ...........................6

5. Generalized map of Glass Mountain extrusive units at northeast wall of Long Valley Caldera

6. Summary of stratigraphic relations and estimated emplacement durations of Bishop Tuff fall units and ignimbrite packages, updated from Wilson and Hildreth .................................

7. Map showing distribution of Long Valley postcaldera rhyolites ...........................................8

8. Comparison plot of compositional ranges of Bishop Tuff and early postcaldera rhyolite .........9

9. Map showing distribution of volcanic vents exposed on and near Mammoth Mountain at southwest margin of Long Valley Caldera .......................................................................11

10. Map of three major mafic lava-flow units in western half of Long Valley Caldera .................13

11. Plot showing silica content versus age: summary for all dated units of the Mammoth system — Mammoth Mountain and peripheral monogenetic eruptive units ...................14

12. Photo of east side of Mammoth Mountain, showing steep former glacial headwall and

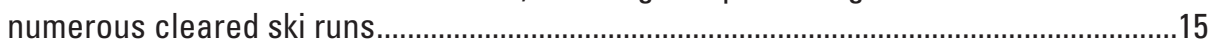

13. Geologic map of Mammoth Mountain …………................................................................17

14. Total alkalis versus $\mathrm{SiO}_{2}$ contents in weight percent for Mammoth Mountain dome complex and peripheral units of wider Mammoth magmatic system .............................................17

15. Plot of total alkalies versus $\mathrm{SiO}_{2}$ and plot of $\mathrm{Zr}$ versus $\mathrm{Ba}$, comparing Long Valley and Mammoth suites ………………….............................................................................19

16. Outline maps with all field-trip stops numbered ...................................................................

17. North side of Mammoth Mountain, viewed from caldera rim $5.5 \mathrm{~km}$ north-northwest of summit.

(3)

23

18. Geologic map of Lakes Basin, a large cirque at south foot of Mammoth Mountain ..............27

19. Peripheral vent cluster 5-9 km south of Mammoth Mountain ...........................................27

20. View northeastward from Mammoth Crest across Lakes Basin and Long Valley Caldera ...28

21. Geologic map of Devils Postpile area along Middle Fork of San Joaquin River .....................28

22. Stratigraphic logs of pumice-fall deposit in Highway 203 roadcut near foot of Mammoth Mountain and at quarry near Cashbaugh Ranch, 17 km east..........................................31

23. Schematic cross section across summit of Mammoth Mountain .........................................32

24. Southeast side of Mammoth Mountain above glaciated trough floored by Twin Lakes........32

25. Town of Mammoth Lakes and four adjacent late Pleistocene lava domes.............................33

26. Photo of outlet arm of Lake Crowley reservoir......................................................................

27. Bishop Tuff plinian fall deposit at Chalfant Valley pumice quarry..........................................36

28. Thin distal bilobate flow unit of Ig1Eb synchronous with deposition of fall unit F8,

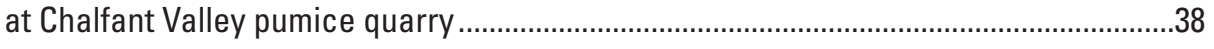

29. View of east wall of Owens River Gorge at UTM 03632/41469.............................................39

30. Entrenched hairpin meander in lower Owens River Gorge ................................................40

31. View upstream from right-bank rim of Owens River Gorge near Stop 19.............................42

32. Photo of zeolitized pillars in nonwelded Bishop Tuff, etched out by wave action at Lake 
33. Little Round Valley viewed southward from crest of knoll 2224 ...............................................44

34. Photo showing nonwelded Bishop Tuff roadcut in Little Round Valley...................................45

35. Map showing shoreline features and deposits of Pleistocene Long Valley Lake...................48

36. Photo of Owens River Bluff sedimentary section .................................................................50

37. Stratigraphic column and plots of microprobe data for Owens River Bluff section shown in

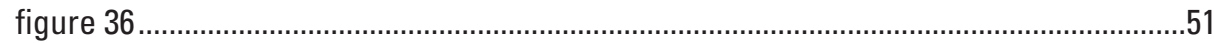

38. Map of early postcaldera rhyolite subdivided into 14 eruptive units .......................................55

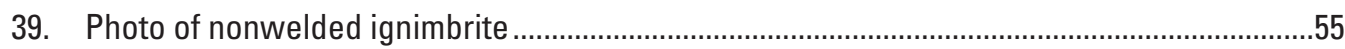

40. Photo of Glass Creek flow draping caldera's northwest wall, 3 km west of Highway 395 at

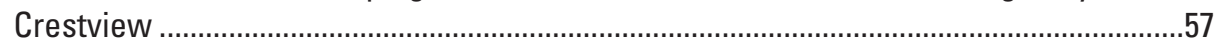

41. Sketch map of precaldera Bald Mountain complex on north-central rim of Long Valley Caldera 



\title{
Geologic Field-Trip Guide to Long Valley Caldera, California
}

\author{
By Wes Hildreth and Judy Fierstein
}

This guide to the geology of Long Valley Caldera is presented in four parts: (1) An overview of the volcanic geology; (2) a chronological summary of the principal geologic events; (3) a road $\log$ with directions and descriptions for 38 field-trip stops; and (4) a summary of the geophysical unrest since 1978 and discussion of its causes. The sequence of stops is arranged as a four-day excursion for the quadrennial General Assembly of the International Association of Volcanology and Chemistry of the Earth's Interior (IAVCEI), centered in Portland, Oregon, in August 2017. Most stops, however, are written freestanding, with directions that allow each one to be visited independently, in any order selected.

\section{Summary of Volcanic Geology}

\section{Setting of Long Valley}

Long Valley Caldera formed at $767 \mathrm{ka}$ by subsidence of a roof plate that consisted of deformed Paleozoic marine metasedimentary strata and subordinate Mesozoic granitoid plutons. The elliptical depression is 17 by $32 \mathrm{~km}$ wide (figs. 1, 2 ) and straddles the range-front boundary between the coherent Sierra Nevada microplate and the extended terrain of the Basin and Range Province. The caldera-producing magma body accumulated at a $15-\mathrm{km}$ left-stepping offset in the Sierran range-front fault system, which initiated here at about 2.5 Ma. Extensional subsidence of Mono Basin to the north also began about this time, and that of Owens Valley to the southeast a little earlier (by $\sim 3 \mathrm{Ma}$ ).

The east-dipping range-front faults of the west-tilted Sierran block have a counterpart, $30 \mathrm{~km}$ east of the caldera (fig. 1), in the west-dipping range-front fault zone of the east-tilted White Mountains block (Stockli and others, 2003). The two great ranges bookend a complexly extended region that includes Owens Valley, Chalfant-Hammil-Benton Valley, Adobe Valley, Round Valley, Long Valley, and Mono Basin (Stevens and others, 2013). Normal dip-slip displacement is large on both range fronts, but the White Mountains-Owens Valley Fault Zone has also been undergoing profound dextral slip as the major element of the Eastern California Shear Zone
(ECSZ). At the north end of the White Mountains, the Mina deflection (Oldow and others, 2008; Nagorsen-Rinke and others, 2013) is an east-northeast-trending right-stepping extensional relay zone that transfers the dextral slip $\sim 50 \mathrm{~km}$ northeast to the Walker Lane Belt (WLB).

The caldera thus lies within a broad zone of intracontinental transtensional deformation. Dextral shear across the ECSZ-WLB accounts for 20-25 percent of the relative motion between the Pacific and North American Plates, and the San Andreas Fault System the other 75-80 percent (Dixon and others, 2000). The Sierran block has moved about $250 \mathrm{~km}$ north-northwest with respect to the Colorado Plateau since $\sim 16 \mathrm{Ma}$, and the Basin and Range Province between may have more than doubled in width (Snow and Wernicke, 2000). Long Valley formed at the far western boundary of the Basin and Range. We have recognized a modest dextral component on the great (principally normal) Round Valley Fault just south of Long Valley (figs. 1, 2), but the range-front faults that were actually cut by caldera subsidence (the Hilton Creek and Hartley Springs Faults) appear to exhibit exclusively normal displacement. The caldera thus lies at the leading edge of the extensional region, but it formed just outside the dextral-slip region.

\section{Precaldera Eruptions of Basalt to Dacite (4.0-2.6 Ma)}

By about $4 \mathrm{Ma}$, decompressing upper mantle began leaking modest batches of alkalic mafic magma to the surface across a broad belt (Moore and Dodge, 1980) that extends from the later site of Long Valley $\sim 40 \mathrm{~km}$ southwest into the Sierra Nevada and $\sim 30 \mathrm{~km}$ northeast into the Adobe Hills (at the Mina deflection; figs. 1,2). Only close to Long Valley (fig. 3) were the precaldera mafic products accompanied by eruptions of trachydacite (3.75-2.6 Ma). Precaldera magmatism was reviewed by Bailey (2004), who observed that the mafic and dacitic magmas ceased erupting by $\sim 2.5 \mathrm{Ma}$, not long before the onset of rhyolitic eruptions at $\sim 2.2 \mathrm{Ma}$. For about $2 \mathrm{~m}$.y. thereafter, an increasingly molten deep-crustal environment evidently favored entrapment of mantle-derived basaltic magma, which, in turn, amplified crustal melting, initiating a prolonged interval of rhyolitic magmatism (which 
$119^{\circ}$

$118^{\circ} 30^{\prime}$

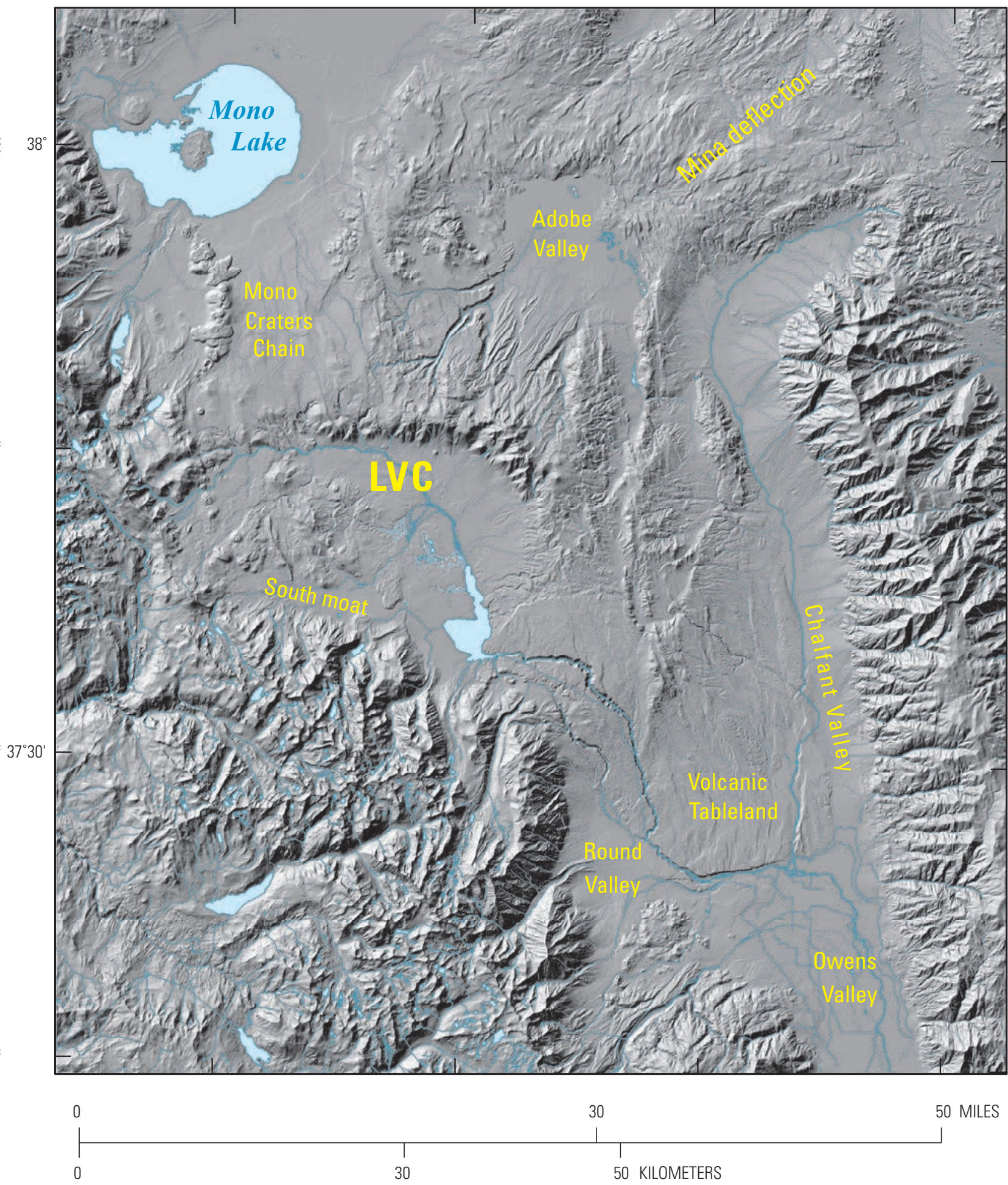

Figure 1. Shaded relief map of Long Valley Caldera (LVC) region at western limit of Basin and Range Province. Rugged Sierra Nevada to southwest and rugged White Mountains to the east. The Mina Deflection is a right-stepping relay zone of faults (many sinistral) that transfer dextral slip from the Eastern California Shear Zone (along the western toe of the White Mountains) to the Walker Lane Belt $\sim 50 \mathrm{~km}$ to the east. In contrast, the Sierran range-front normal fault system steps left 15-20 km across the site of the caldera, which it predates by $\sim 2$ m.y. Owens River Gorge drains Lake Crowley reservoir at southeast side of caldera. Volcanic Tableland is major southeast outflow sheet of Bishop Tuff, the 767-ka caldera-forming ignimbrite. Younger than Long Valley rhyolitic activity (2.2-0.1 Ma), Mono Craters is a separate discrete chain of $\sim 30$ high-silica rhyolite extrusions, many of them Holocene in age. 


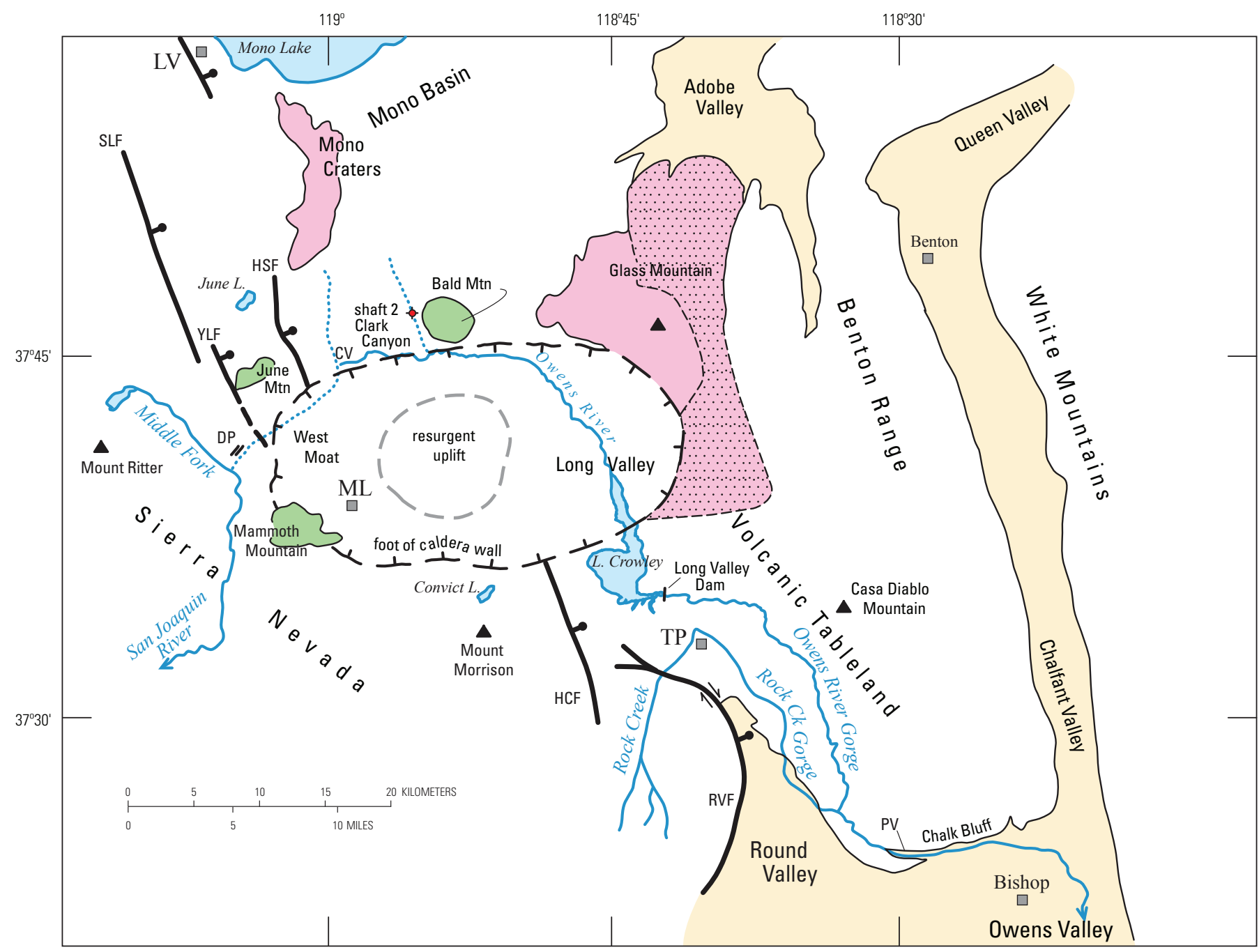

Figure 2. Regional location map indicating many geographic features mentioned in text. Eruption of $\sim 650 \mathrm{~km}^{3}$ of rhyolite magma as the Bishop Tuff at $767 \mathrm{ka}$ was accompanied by 2-3 km of caldera subsidence. Growth of a caldera lake began immediately, but resurgent structural uplift reduced the lake to the eastern half of the depression (Long Valley proper). Lacustrine deposition of $\sim 700 \mathrm{~m}$ of ashrich sediment took more than 600,000 years to raise the persistently shallow lake to its threshold for overflow. Ultimate overflow cut 30-km-long Owens River Gorge through the Bishop Tuff ignimbrite outflow sheet on the Volcanic Tableland. Dotted blue lines indicate two ancestral streams of Pliocene age: paleo-Owens River buried by Bishop Tuff north of Clark Canyon; and a paleo-tributary of the Middle Fork San Joaquin River, blocked by a stack of Pliocene basalts prior to range-front faulting. Precaldera gravels of paleo-Owens River were intersected at Clark Canyon in shaft 2 of Mono Craters tunnel (Jacques, 1940). Lake Crowley is a reservoir impounded by Long Valley Dam since 1941, not a remnant of the caldera lake. Precaldera Glass Mountain rhyolite dome complex is adjoined by its own pyroclastic fan (stippled), which contributed voluminous sediment to the Pleistocene lake. Abbreviations: CV, Crestview; DP, Deadman Pass; HCF, Hilton Creek Fault; HSF, Hartley Springs Fault; LV, town of Lee Vining; ML, town of Mammoth Lakes; PV, Pleasant Valley; RVF, Round Valley Fault; SLF, Silver Lake Fault; TP, Toms Place; YLF, Yost Lake Fault. 


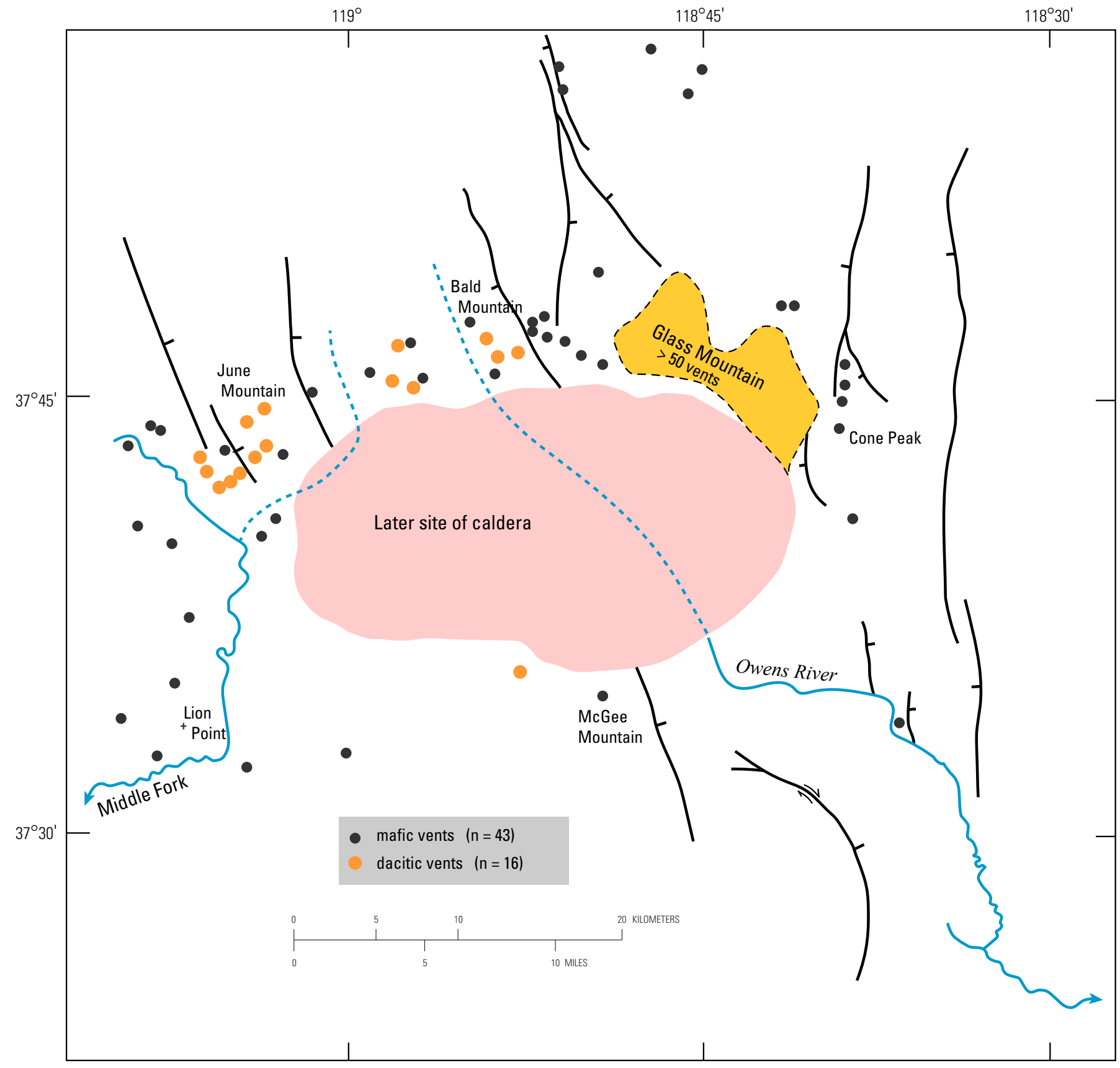

Figure 3. Precaldera volcanic vents and main Basin and Range extensional faults peripheral to later site of Long Valley Caldera. Basaltic, trachyandesitic, and trachydacitic vents are all Pliocene (4.0-2.6 Ma). Tightly clustered Glass Mountain high-silica-rhyolite vents are all early Pleistocene (2.2-0.8 Ma). Dotted blue lines indicate inferred courses of two Neogene streams: (1) northeast tributary canyon of Middle Fork of San Joaquin River was filled by $400 \mathrm{~m}$ of basaltic lava flows (3.7-3.3 Ma) and thereafter diverted to Owens River; (2) main course of upper Owens River was destroyed by caldera collapse at $767 \mathrm{ka}$, thereafter terminating in a large caldera lake, which took $\sim 600,000$ years to fill with more than $700 \mathrm{~m}$ of sediment before reaching its spillpoint. 
included caldera collapse at $767 \mathrm{ka}$ ). Not until $230 \mathrm{ka}$ did mafic eruptions resume, and even those are limited to a belt west of the structural caldera.

\section{Precaldera Eruptions of Glass Mountain Rhyolite (2.2-0.8 Ma)}

Glass Mountain (figs. 4, 5) is a sprawling precaldera complex (2.2-0.8 Ma) of $>60$ eruptive units, exclusively high-silica rhyolite (76.6-77.7 percent $\mathrm{SiO}_{2}$ ), at the northeast periphery of Long Valley caldera where the rhyolites are exposed to a thickness of more than $1,100 \mathrm{~m}$ on the caldera wall (Metz and Mahood, 1985, 1991; Metz and Bailey, 1993). At least $50 \mathrm{~km}^{3}$ of rhyolitic material is preserved as lava flows, domes, proximal tuff, and extensive fans of pyroclastic and reworked debris. Based on the pattern of intersection of caldera faults with the Glass Mountain edifice and the abundance of Glass Mountain lithic fragments in the Bishop Tuff (Hildreth and Mahood, 1986), we estimate that as much as $10 \mathrm{~km}^{3}$ more is downfaulted beneath the caldera floor. Numerous plinian events distributed Glass Mountain fallout from the Pacific Ocean to Utah (Izett and others, 1988), though the total volume is hard to estimate from the scattered remnants. The aggregate thickness of fall units is several meters in pumice quarries $15-20 \mathrm{~km}$ east of Glass Mountain (Sarna-Wojcicki and others, 2005). Along with preservation of ash layers as far as $470 \mathrm{~km}$ south and $550 \mathrm{~km}$ east, this suggests a dispersed volume of tephra in the range $50-100 \mathrm{~km}^{3}$ - or $25-50 \mathrm{~km}^{3}$ of hydrous high-silica-rhyolite magma. Total magma volume released by the Glass Mountain center may thus have been $100 \pm 20 \mathrm{~km}^{3}$ - all of it high-silica rhyolite. A few individual fall units may have reached $10 \mathrm{~km}^{3}$, whereas hardly any of the lavas are individually as voluminous as $1 \mathrm{~km}^{3}$.

Compositions of Glass Mountain lavas fall into two groups: (1) An older sequence (2.2-1.3 Ma) of at least 24 eruptive units, all high-silica rhyolite but chemically varied, tapped sporadically from several discrete bodies at different stages of evolution, including some units considerably more enriched than the Bishop Tuff in incompatible trace elements; and (2) a younger sequence (1.2-0.8 Ma) of at least 35 eruptive units, all of them geochemically similar to the more evolved end of the compositionally zoned Bishop Tuff array, and presumably tapped from a common, by-then-integrated, expanding magma chamber (Metz and Mahood, 1991; Metz and Bailey, 1993). Most of the Glass Mountain rhyolites are crystal-poor; a dozen have 6-8 percent phenocrysts, but the great majority have $0-5$ percent (fig. 5). Phenocryst abundances, species, and compositions resemble those of the evolved, first-erupted part of the zoned Bishop Tuff, most units having quartz, sanidine, plagioclase, biotite, allanite, zircon, apatite, and Fe-Ti oxides.

\section{Climactic Eruption and Caldera Formation}

The caldera-forming eruption of the Bishop Tuff at 767 ka began as a Plinian outburst along or near the Hilton Creek
Fault in the south-central part of what soon became the caldera (Hildreth and Mahood, 1986). The roof of the growing chamber, then about $5 \mathrm{~km}$ deep (Wallace and others, 1999), ultimately failed catastrophically, releasing $\sim 650 \mathrm{~km}^{3}$ of gasrich rhyolitic magma, compositionally and thermally zoned (Hildreth and Wilson, 2007), in a virtually continuous eruption about 6 days long (Wilson and Hildreth, 1997), thereby permitting 2-3 km subsidence of the roof plate, creating the caldera. About half the Bishop Tuff volume was emplaced radially as a set of sectorially distributed ignimbrite outflow sheets along with concurrent coignimbrite and plinian fallout. The other half ponded inside the subsiding caldera, where welded intracaldera ignimbrite is as thick as $1,500 \mathrm{~m}$ and was subsequently buried by $500-800 \mathrm{~m}$ of postcaldera rhyolite tuffs, lavas, and sedimentary fill (Bailey, 1989; Hildreth and Fierstein, 2016a, b). Pumice clasts in the Bishop Tuff are zoned from 1 to 25 weight percent phenocrysts and define a compositional continuum in the range 78-73 percent $\mathrm{SiO}_{2}$ and 2-600 ppm Ba (Hildreth and Wilson, 2007). The main suite of white pumice is accompanied by a sparse population of crystal-poor variant pumice that extends the range to 65 percent $\mathrm{SiO}_{2}$ and to $1,350 \mathrm{ppm} \mathrm{Ba}$ (Hildreth and Wilson, 2007). The sequence of lithologically distinguishable ignimbrite packages and the nine concurrently erupted plinian fall units (fig. 6) was worked out by Wilson and Hildreth (1997). Pre-eruptive magma temperatures recorded by pristine $\mathrm{Fe}-$ Ti-oxide pairs range from 700 to $820^{\circ} \mathrm{C}$ (Evans and others, 2016).

The 17-by-32-km depression called Long Valley Caldera owes its dimensions and the physiography of its walls to large-scale syneruptive slumping (see Lipman, 1997) and to subsequent erosion. As inferred from gravity, drillholes, and vent distribution (Carle, 1988; Suemnicht and Varga, 1988; Hildreth, 2004; Hildreth and Fierstein, 2016a), the ring-fault zone, which outlines the area of steep structural collapse of the cauldron (roof) plate into the magma reservoir, encloses a subsided oval 12 by $22 \mathrm{~km}\left(\sim 220 \mathrm{~km}^{2}\right)$, roughly 55 percent of the $400-\mathrm{km}^{2}$ floor of the topographic-hydrographic basin conventionally portrayed as Long Valley Caldera. The magma chamber had to be somewhat wider than the roof plate that sank into it. Nonetheless, clarity in definition of the structural caldera can help avoid misleading conceptualizations. For example, Mammoth Mountain is sometimes said to straddle the caldera rim, but it is actually an extracaldera volcano banked against a glaciated granite wall, well outside the ring fault zone, compositionally and spatially independent of the Long Valley magma reservoir (Hildreth, 2004; Hildreth and others, 2014).

Seismic refraction profiles (Hill, 1976; Hill and others, 1985) and gravity models (Carle, 1988) indicate that the caldera fill thickens substantially toward the north and east, as confirmed in drillholes that show the intracaldera Bishop Tuff thickening from $0.9-1.2 \mathrm{~km}$ centrally to $\sim 1.5 \mathrm{~km}$ in the eastern third of the caldera (Bailey, 1989). What fractions of the thickening may reflect precaldera topography, differential magma withdrawal, or tilting of the roof plate during collapse 


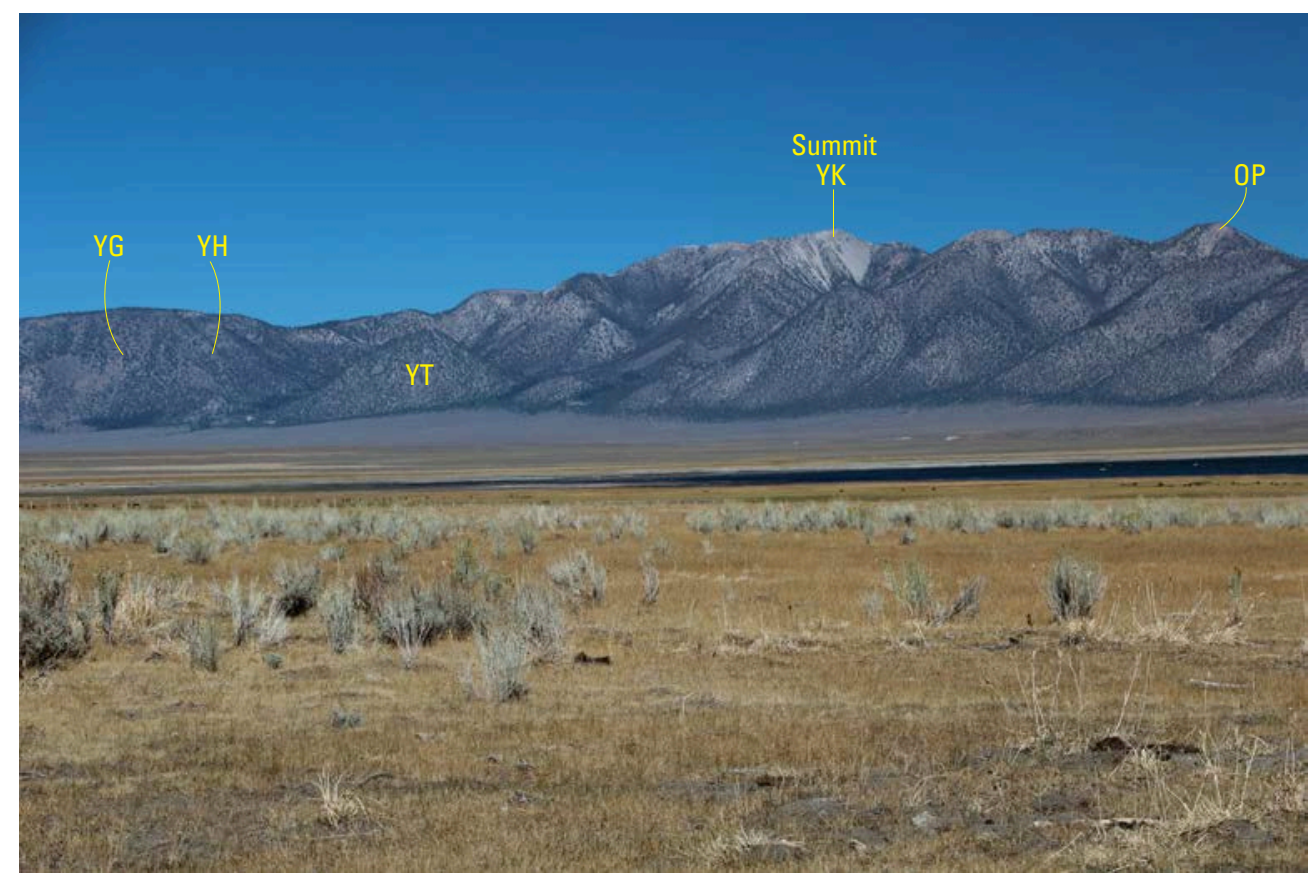

Figure 4. Glass Mountain rhyolite dome field on northeast wall of Long Valley Caldera. View is toward north-northeast from Long Valley lowland. The complex includes $\sim 60$ domes and coulees of high-silica rhyolite, all of early Pleistocene age (2.2-0.8 Ma). Five domes are labeled according to the comprehensive nomenclature of Metz and Bailey (1993) shown in figure 5. $0^{\prime}$ Harrel Canyon is to the left of Dome YT. Summit dome YK has an elevation of $3,390 \mathrm{~m}$. The head of the alluvial apron is at $~ 2,300 \mathrm{~m}$, giving $\sim 1,100 \mathrm{~m}$ of exposed relief on the rhyolitic edifice. Width of view is $\sim 8.5 \mathrm{~km}$ along base of edifice, which also extends $\sim 2 \mathrm{~km}$ farther to left and right of the image.

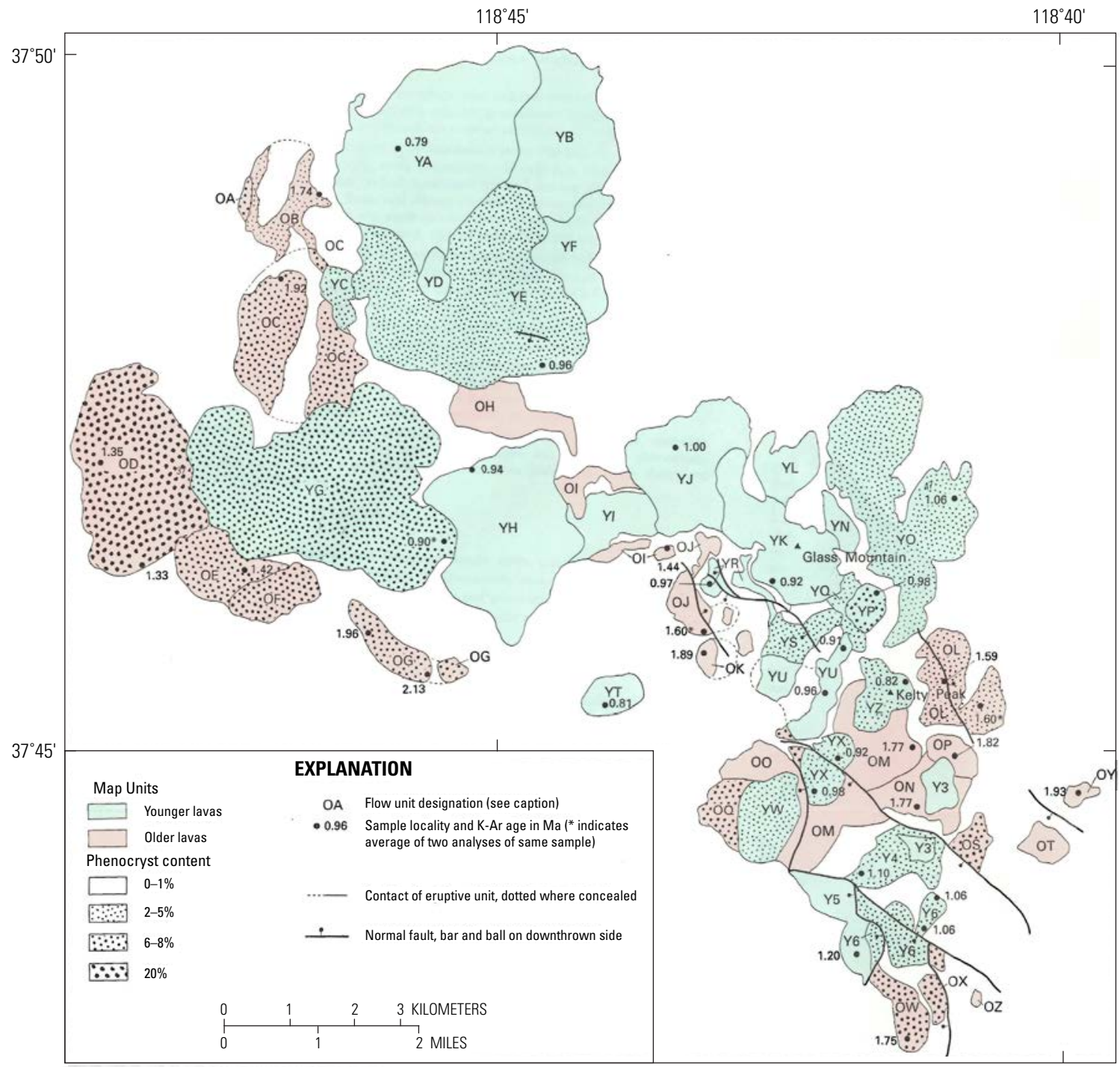

Figure 5. Generalized map of Glass Mountain extrusive units (2.2-0.8 Ma) at northeast wall of Long Valley Caldera (after Metz and Bailey, 1993). Map divides 59 lavas into older $(0)$ and younger $(\mathrm{Y})$ sets, portrays phenocryst contents for all (in percent, \%), and gives $\mathrm{K}$-Ar ages for many. All are high-silica rhyolite, as documented by Metz and Mahood (1985, 1991). 
remain uncertain. The Hilton Creek Fault (figs. 1, 2), where the caldera-forming eruption began, clearly had several hundred meters of east-facing precaldera relief. Where the caldera center lies now, a north-sloping ramp (Bailey, 1989) probably separated the en-echelon Hilton Creek and Hartley Springs Faults (figs. 1, 2). Greater subsidence in the north and east is also consistent with stratigraphic and petrological evidence that the final eruptive packages of the Bishop Tuff, which preferentially flowed toward those sectors (fig. 6), were withdrawn from deeper, hotter levels of the magma reservoir (Hildreth, 1979; Hildreth and Mahood, 1986; Wilson and Hildreth, 1997; Wallace and others, 1999; Hildreth and Wilson, 2007; Chamberlain and others, 2015).

\section{Early Postcaldera Rhyolite (ER)}

What Bailey and others (1976) termed the "early rhyolite" (fig. 7) consists of $\sim 100 \mathrm{~km}^{3}$ of fairly uniform, phenocryst-poor rhyolite (74-75 percent $\mathrm{SiO}_{2}$ ) that erupted during the 120,000-yr interval following caldera collapse. This enormous volume, locally thicker than $600 \mathrm{~m}$, is as great as that of precaldera Glass Mountain and an order of magnitude greater than the total of all subsequent Long Valley rhyolites erupted in the last half-million years. Released in many separate eruptions from at least 12 vents (Hildreth and others, 2017), the early rhyolite (ER) includes 11 exposed lava flows (and domes), several more intersected by drilling, and a

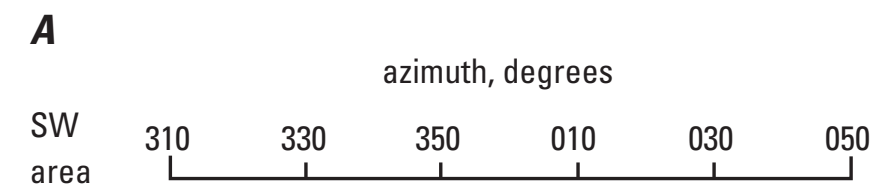

\section{B}

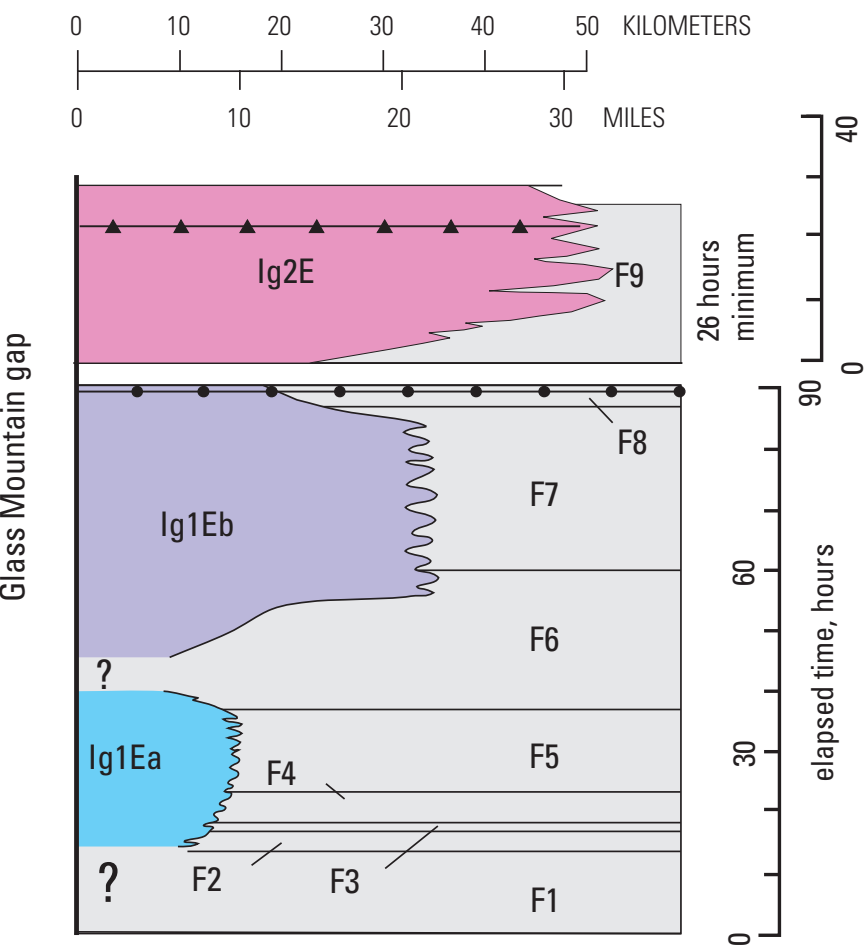

Figure 6. Summary of stratigraphic relations and estimated emplacement durations of Bishop Tuff fall units (F) and ignimbrite packages ( $\mathrm{g}$ ), updated from Wilson and Hildreth (1997). “Glass Mountain gap” represents the gap in information (inset map) on and northeast of Glass Mountain, where all Bishop Tuff deposits have been removed by erosion. Vertical distances are scaled to a composite timescale, which is separated by a short time break between F8 and F9. Left-hand side (A) shows a hypothetical west to east section along an arc from $310^{\circ}$ to $050^{\circ}$ (relative to grid north, as projected from an arbitrary origin in the center of Long Valley Caldera; see inset map), with the northern ignimbrite subpackages drawn to represent their projected dispersal sectors (horizontal scale) and relative stratigraphic positions (vertical scale). Right-hand side $(B)$ illustrates a section from proximal to distal areas, roughly along the line of Owens River Gorge; horizontal axis is distance from the initial vent area (Hildreth and Mahood, 1986). Fall deposits are shaded gray and labeled F1 through F9. The two sides of the figure are linked by a pair of inferred time-marker planes: (1) the first appearances of both Glass Mountain-derived (GM) rhyolite lithics (eastern ignimbrite and Ig2N) and pyroxene-bearing pumices (both sides); and (2) the first appearance of clasts of recycled intracaldera Bishop Tuff ignimbrite that itself contains rhyolite lithics. On inset map, cluster of small outcrops southwest of caldera are remnants of packages Ig1SW and Ig2SW along glaciated canyon of San Joaquin River. 


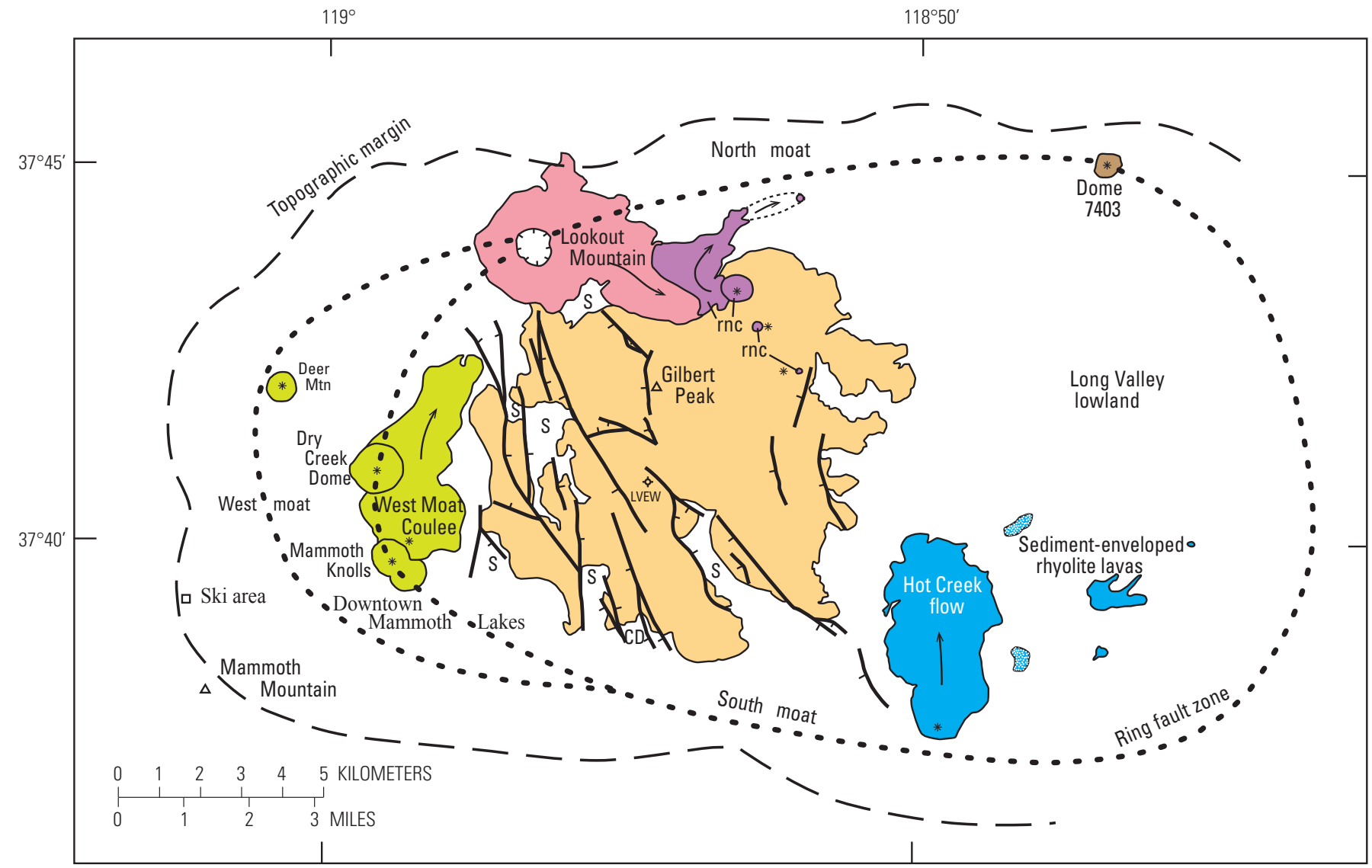

Figure 7. Map showing distribution of Long Valley postcaldera rhyolites. Early postcaldera rhyolite (750-640 ka) lavas, shown in orange, are cut by numerous faults associated with structural resurgent uplift. Lookout Mountain, in red, is also early rhyolite $(\sim 680$ ka) but is not deformed. Three sets of moat rhyolite lavas crop out in north (unit rnc, 570-505 ka, purple), southeast (362-328 ka, blue), and west (150-100 ka, green). The north and west sets are all crystal-rich, as are the two patterned lavas in the southeast set. Four (of the six) units in the southeast set and all of the early rhyolites are phenocryst-poor (0-3 weight percent). Rhyodacite Dome 7403 in the northeast moat is undated but younger than $\sim 150 \mathrm{ka}$. Arrows generalize lava flow directions. Estimated position of main ring-fault zone (dotted line) is 2-4 km inboard of topographic margin (dashed line), which receded by syncollapse landsliding and subsequent erosion. Complexly stepped structure of concealed faults in west moat, inferred from drillholes, is enclosed by pair of dotted lines. Abbreviations: CD, Casa Diablo geothermal plant; Ski area, Mammoth Mountain Ski Area; LVEW, Long Valley Exploratory Well, 3 km deep, located high on resurgent uplift; s, surficial deposits filling structural lows on resurgent uplift.

predominance of varied tuffs (mostly nonwelded pyroclasticflow deposits) that make up about three-quarters of the ER assemblage. About 35 radioisotopic ages range from $\sim 750 \mathrm{ka}$ to $\sim 640 \mathrm{ka}$. The ER extends far beyond its outcrop area (fig. 7), as documented in numerous wells (Suemnicht and Varga, 1988; Bailey, 1989; Hildreth and Fierstein, 2016a). At least $622 \mathrm{~m}$ thick near its center of outcrop, the ER assemblage is still 230 to $537 \mathrm{~m}$ thick in wells in the caldera's west moat where buried by younger units.

Because no correlative layers of distal ash are reported outside Long Valley, it seems likely that eruptions of ER tephra, though numerous, were subplinian and individually modest in volume. This might be interpreted to mean that the residual rhyolite magma had been relatively depleted in volatiles during the caldera-forming eruption, but, on the other hand, the observation that three-quarters of the biotitebearing ER is pyroclastic and nearly aphyric indicates that the ER magma was water-rich. Perhaps the abundance of medium-scale ER eruptions reflected relative ease of magma escape through the downfaulted and broken roof plate, thereby aborting, by frequent eruptive release (and perhaps also by passive degassing), any postcaldera recurrence of severe gas overpressure.

Compositions of ER are similar in most respects to the last-erupted part of the zoned Bishop Tuff, except that a few elements ( $\mathrm{Zr}$ and $\mathrm{Ba}$ ) extend the range of Bishop zoning (fig. 8 ). Phenocryst contents of the ER are low, only 0-3 percent, compared to $15-25$ percent in the directly preceding, lasterupted part of the Bishop Tuff. The dominating minerals in the Bishop Tuff, sanidine and quartz, are absent in ER, and the sparse crystals present are all new, euhedral to subhedral. These include plagioclase, orthopyroxene, Fe-Ti oxides, and (in most units) rare biotite, as well as traces of apatite, zircon, and pyrrhotite. Our microprobe analyses of eight Fe-Ti oxide pairs gave ranges of $752-844^{\circ} \mathrm{C}$ and $\Delta \mathrm{NNO}=-0.3$ to -0.65 . 


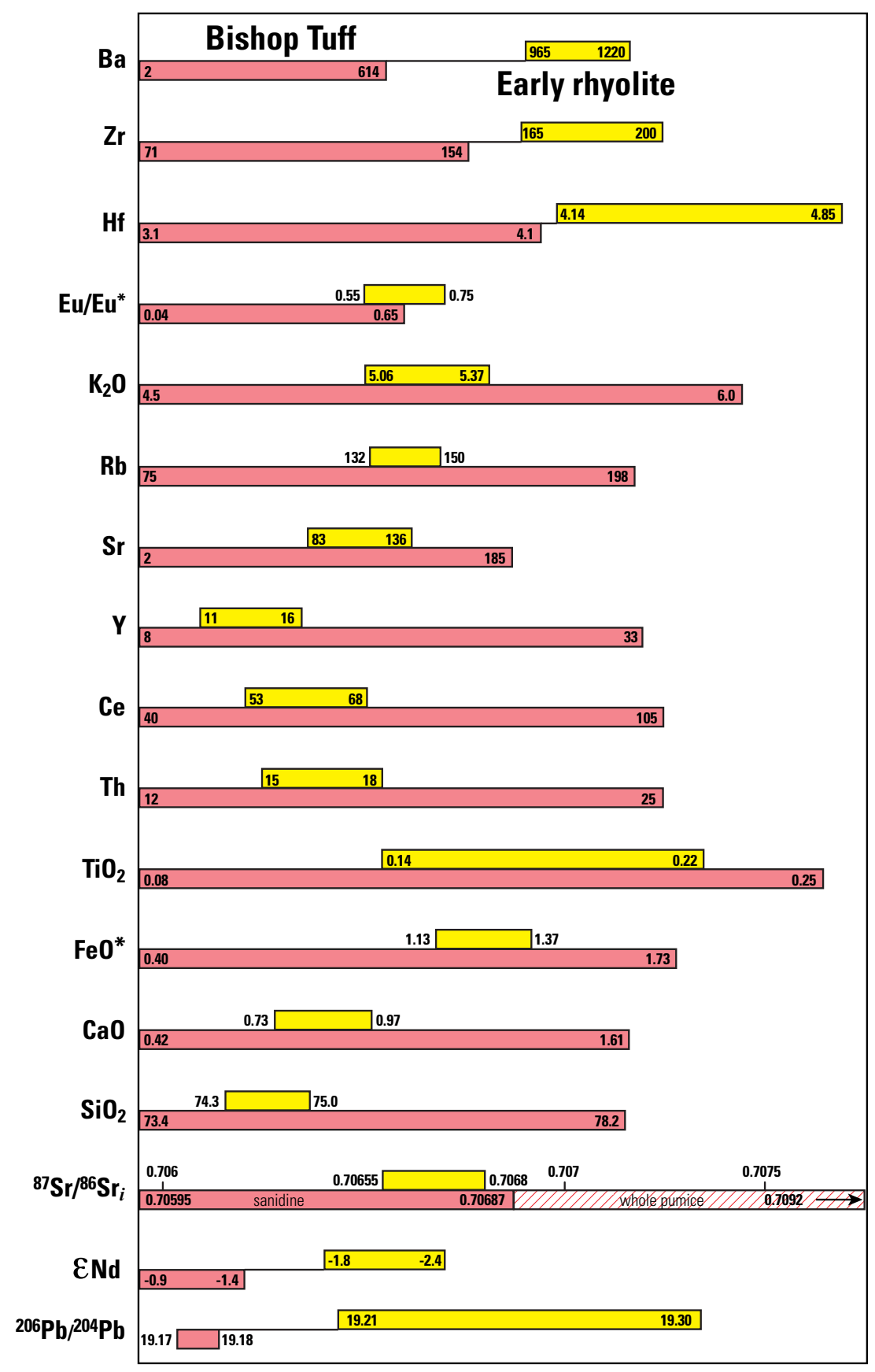

Figure 8. Comparison plot of compositional ranges of Bishop Tuff (BT, red) and early postcaldera rhyolite (ER, yellow). Major elements in weight percent; trace elements in parts per million. Lowest and highest concentrations are given for BT and ER along a common scale, which is unique for each element. Arrays represent 108 early rhyolite obsidians and fresh felsites and $>300$ discrete pumice clasts from the Bishop Tuff. Early rhyolite values are intermediate along arrays for continuously zoned Bishop Tuff for all entries except $\mathrm{Ba}, \mathrm{Zr}, \mathrm{Hf}, \mathrm{Eu} / \mathrm{Eu}^{*}$, and $\mathcal{E} \mathrm{Nd}$. BT data mainly from Hildreth and Wilson (2007); a few from Hildreth (1977), Halliday and others (1984), and Davies and Halliday (1998). ER data from Hildreth and others (2017); some from Heumann and Davies (1997), Heumann (1999), and Simon and others (2014). For BT initial Sr-isotope array, solid-red segment is for sanidine data only; shaded segment represents glass and whole-pumice ratios apparently modified by groundwater hydration along with some posteruptive radiogenic ingrowth in samples having as little as $2-30 \mathrm{ppm} \mathrm{Sr}$.

The contrast in crystal content between late Bishop Tuff and (compositionally similar) postcollapse ER might reflect (1) wholesale resorption of crystals in unerupted rhyolite magma during convective reorganization of the postcollapse reservoir, owing to heating by (and limited mixing with) hotter dacitic or mafic magma drawn up from deeper levels; or (2) pressure-release melting of the crystals in rhyolite magma that convectively rose several kilometers to replace the topmost zone of the reorganized chamber; or (3) resorption of phenocrysts in such magma (previously deeper and water-undersaturated) drawn to the top of the partially evacuated chamber and subsequently saturated with water, owing to bubble ascent and concentration near the roof of aqueous gas exsolved from still-deeper (untapped) parts of the reservoir during the climactic depressurization; or (4) similar resorption caused by $\mathrm{CO}_{2}$ exsolution (thereby raising $\mathrm{H}_{2} \mathrm{O}$ activity) during ascent of gas-saturated but formerly $\mathrm{CO}_{2}$-richer rhyolite magma from deeper in the reservoir; or (5) concentration at the top of the chamber (in response to depressurization and reorganization) of interstitial melt expelled from a great reservoir of crystal mush that had underlain the zoned magma lost as the Bishop Tuff (Hildreth, 2004; Hildreth and Wilson, 2007).

Similarities in composition (fig. 8) and temperature (Hildreth and others, 2017) between ER and late-erupted parts of the Bishop Tuff suggest that mixing with hotter, deeper magma was limited, while the relatively elevated $\mathrm{Ba}$ content 
of ER (fig. 8) suggests contributions either from dacitic or trachytic magma or from partial resorption of sanidine-rich cumulate mush. Sparse mafic enclaves (50-58 percent $\mathrm{SiO}_{2}$ ) reflecting recharge have been found in only two ER lavas and rare mafic blebs in two more.

\section{Structural Resurgence}

Long Valley's resurgent uplift is $\sim 10 \mathrm{~km}$ in diameter, has maximum topographic relief of $\sim 500 \mathrm{~m}$, and lies well west of the caldera's center (fig. 2). Exposed rocks uplifted by the resurgence are predominantly ER, but the deformation also affected fringes of lacustrine sandstone along the east margin of the uplift and mafic lava flows along the west and southwest margins, both of middle Pleistocene age and only mildly warped. Despite regional east-west tectonic extension and east-west elliptical elongation of the caldera, the resurgent uplift is equant in plan. Structural resurgence does not affect the ER of Lookout Mountain (unit rlm).

Intracaldera resurgence was defined by Smith and Bailey (1968) as structural uplift of the caldera floor by renewed buoyancy or intrusion of viscous magma remaining in the postcollapse reservoir; but the term has sometimes been inappropriately conflated with postcaldera eruptive activity that may or may not accompany such uplift. Bailey and others (1976) inferred that structural uplift at Long Valley was largely contemporaneous with the $\sim 110-k . y$. interval of ER eruptions and was probably largely over by $\sim 500 \mathrm{ka}$. The roughly circular area of uplift (fig. 2) dips radially outward at $10-25^{\circ}$ (Bailey, 1989). Lookout Mountain ( $\left.\sim 680 \mathrm{ka}\right)$, an ER shield in the northwest moat, is outside the uplift (fig. 2), as are thick sections of ER concealed by sediments and lavas beneath other sectors of the moat.

The high point of the uplift is Gilbert Peak (2,626 m asl; fig. 2) and, if ER thickness there is similar to that (622 m) in the Long Valley Exploratory Well (LVEW) $\sim 2 \mathrm{~km}$ south (fig. 7), then the top of the subjacent Bishop Tuff would be $\sim 2,000 \mathrm{~m}$ above sea level (asl), probably its maximum intracaldera elevation. This is $469 \mathrm{~m}$ higher than in well 44-16 in the west moat and $575 \mathrm{~m}$ higher than in well 66-29 in the southeast moat (fig. 9; Suemnicht and Varga, 1988; Bailey, 1989; Fournier, 1989). It seems likely that the fluidized primary surface of the kilometer-thick Bishop Tuff that ponded inside the caldera was nearly horizontal at the close of its eruption. Therefore, even though part of the excess elevation of the resurgent dome owes to the constructional pile of proximal ER, and part to differential compaction of the Bishop Tuff (which is thicker in the low eastern third of the caldera; Hill, 1976; Bailey, 1989), doming of the top surface of the Bishop Tuff clearly demonstrates central uplift of at least $400 \mathrm{~m}$. Most of the uplift appears to have been during ER time, but what fraction may have continued episodically is not clear. The 400-m total uplift in roughly $100 \mathrm{k} . \mathrm{y}$. ( $4 \mathrm{~mm} / \mathrm{yr}$ ) can be compared with $\sim 83 \mathrm{~cm}$ of ongoing uplift since 1980 (24 mm/yr) (Savage and Clark, 1982; Hill and others, 2002; Langbein, 2003; Montgomery-Brown and others, 2015).

Drillcore from well LVEW (virtually central to the uplift) revealed, within the 1.2-km-thick section of Bishop Tuff penetrated, some 10 phenocryst-poor intrusions, apparently sill-like and not present in wells drilled peripheral to the uplift (McConnell and others, 1995). Compositionally, the sills are Ba-rich rhyolite much like the ER and, with a cumulative thickness of $\sim 330 \mathrm{~m}$, they could account for most of the resurgent uplift. For a 10-km-wide domical uplift of $400 \mathrm{~m}$, the apparent volume of inflation is about $10 \mathrm{~km}^{3}$, merely 10 percent of the volume of ER erupted. The conventional model that a resurgent residual magma chamber buoyantly upwarps the cauldron block by reinflation or upward intrusion is, therefore, for Long Valley, no more compelling than a model of central uplift by injection of shallow sills or laccoliths into the thick intracaldera fill (McConnell and others, 1995).

Two main sets of extensional faults cut the ER (fig. 7). Associated with resurgent uplift of the western half of the floor of Long Valley Caldera, the faults frame two complex graben, here called the Fumarole Valley graben, which trends $\mathrm{N} 35^{\circ} \mathrm{W}$, and the Smokey Bear Flat graben, which trends N $20^{\circ} \mathrm{W}$. The former, $\sim 1.3 \mathrm{~km}$ wide, indents only the southeastern sector of the resurgent uplift. The latter, 1.5-2 km wide, transects the entire uplift across its western flank.

The fault system is dominated by trends nearly parallel to those of range-front faults north and south of the caldera (figs. 1,2 ), but also parallel to the strike of steeply dipping structures and bedding in metamorphic basement rocks (Rinehart and Ross, 1964). No radial or concentric faults, as might be associated with domical uplift, are present, and no strike-slip component of displacement is recognized on what appear to be exclusively normal faults. The structure of the uplift thus appears to have been influenced more by (1) regional precaldera structures and (2) susceptibility of the shallow, subhorizontally layered Bishop Tuff to sill injection rather than by chamber-wide buoyancy. Location of the uplift nonetheless surely reflects the main locus of the reorganized postcaldera magma reservoir, which so voluminously supplied the ER. For the last half-million years, however, despite paths provided by the complex fault system (fig. 7), there have been no further eruptions on the resurgent dome.

\section{Younger Long Valley Rhyolites}

After the final early rhyolite (ER) eruptions (about $640 \mathrm{ka}$ ), there ensued an extended hiatus before the first of several episodic sets of Long Valley rhyolite lavas was emplaced in the periphery of the resurgent uplift (fig. 7). First was a chain of three small domes and one coulee (570-505 ka) on the northeast flank of the ER. Second was a set of six domes and flows $(362-329 \mathrm{ka})$ in contact with caldera-lake sediment in the caldera's southeast moat. Third was the 150-ka West Moat Coulee, and fourth was a set of three small 115-100 ka domes in the west moat. The crystal-rich rhyolite component 


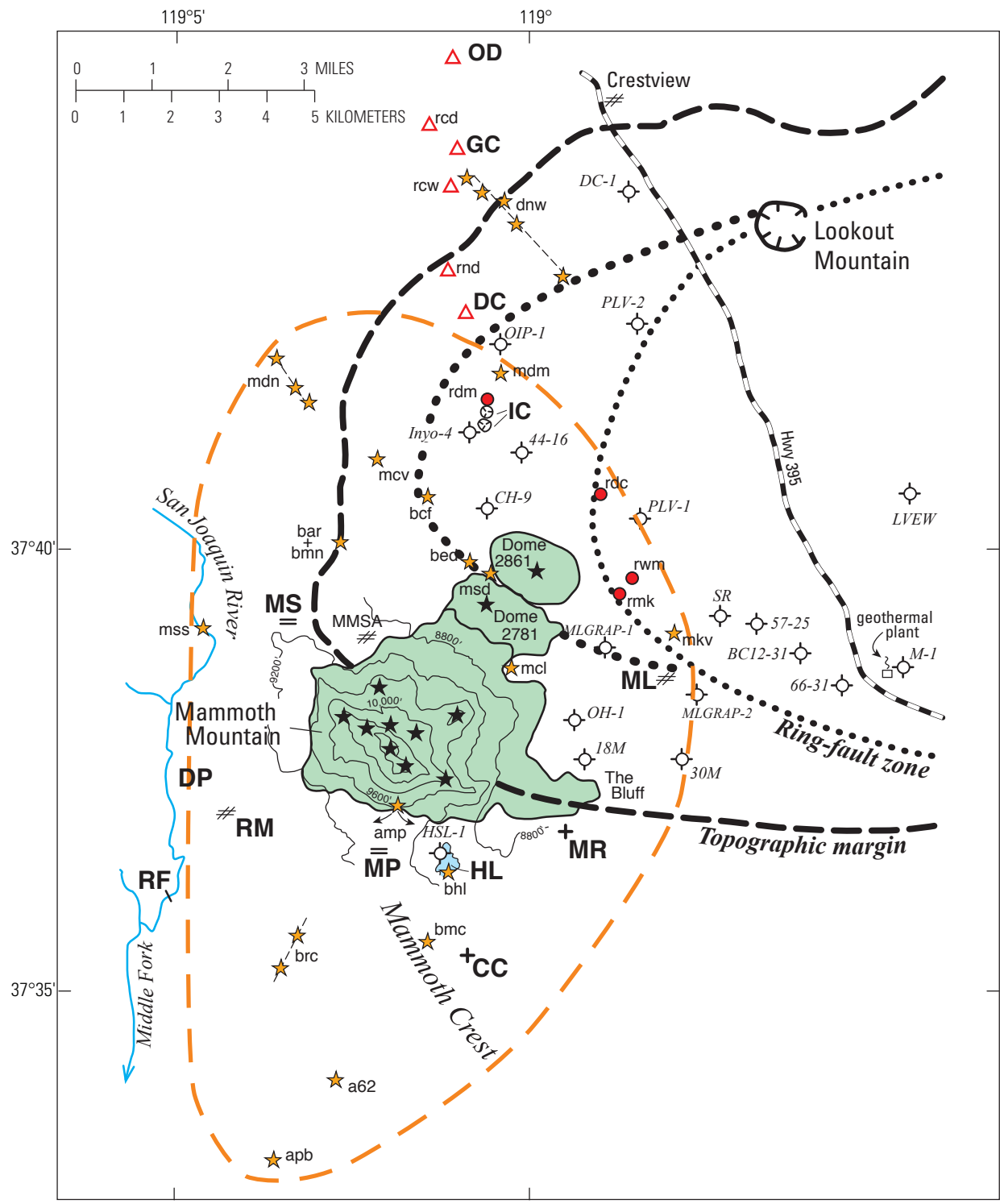

\section{EXPLANATION}

$\triangle$ Inyo chain

DC Deadman Creek flow

GC Glass Creek flow

OD Obsidian Dome

rcd rhyolite of Cratered Dome

rcw rhyolite of caldera wall

rnd rhyolite of North Deadman Creek Dome

$\star$ Vents of Mammoth Mountain trachydacites and alkalic rhyodacites

it Vents of basalts and trachyandesites a62 trachyandesite of Cone 2962

amp trachyandesite of Mammoth Pass

apb trachyandesite of Pumice Butte

bar trachybasalt of Arcularius Ranch

bcf trachybasalt south of Crater Flat

bed basalt east of Dry Creek

bhl basalt of Horseshoe Lake

bmc basalt of Mammoth Crest

bmn trachybasalt northeast of Minaret Summit

brc basalt of Red Cones

dnw trachydacites of Northwest Moat

mcl basaltic trachyandesite of Canyon Lodge

mcv basaltic trachyandesite south of Crestview

mkv basaltic trachyandesite of Knolls Vista

$\mathrm{mdm}$ basaltic trachyandesite of Deer Mountain mdn basaltic trachyandesite NE of Deadman Pass

msd basaltic trachyandesite scoria SE of Dry Creek mss basaltic trachyandesite of upper Soda Springs

- Long Valley rhyolites (160-100 ka)

rdc rhyolite of Dry Creek Dome

rdm rhyolite of Deer Mountain

rmk rhyolite of Mammoth Knolls

rwm rhyolite of West Moat Coulee

$-\phi$ - Drill sites, identified by well name

Figure 9. Map showing distribution of volcanic vents exposed on and near Mammoth Mountain at southwest margin of Long Valley Caldera. Mammoth Mountain edifice is colored green, and its exposed vents are indicated by black stars. Peripheral mafic and intermediate vents are represented by orange stars, and the ovoid volcanic field they represent is enclosed by an orange dashed line. Four subalkaline Long Valley rhyolites contemporaneous with the alkaline Mammoth system are indicated by red dots. Red triangles represent Holocene rhyolitic Inyo chain; of these, those indicated by bold letters erupted in 1350 C.E. All 3-letter unit labels identified and discussed by Hildreth and Fierstein (2016a). Other abbreviations: CC, Cathedral Crag; DP, Devils Postpile; HL, Horseshoe Lake; LM, Lookout Mountain; ML, downtown Mammoth Lakes; MP, Mammoth Pass; MR, Mammoth Rock; MS, Minaret Summit; RF, Rainbow Falls; RM, Reds Meadow. 
of the 1350 C.E. mixed eruption of the Inyo Chain is also residual Long Valley magma. Geochemical investigations of some of the younger rhyolites were published by Sampson and Cameron (1987), Reid and others (1997), Heumann and Davies (1997), Heumann and others (2002), and Simon and others (2014). Compositional and volcanological aspects of all 15 units were summarized by Hildreth (2004) and Hildreth and Fierstein (2016a), who also compiled radiometric ages determined in several laboratories.

Simon and others (2014) recently published new sanidine ${ }^{40} \mathrm{Ar} /{ }^{39} \mathrm{Ar}$ ages for the Hot Creek coulee (333 $\left.\pm 2 \mathrm{ka}\right)$ in the southeast moat and for North Dome (570 $\pm 9 \mathrm{ka})$ and its derivative coulee $(570 \pm 7 \mathrm{ka})$ in the northeast chain. Age clusters of $750-640 \mathrm{ka}, 570-505 \mathrm{ka}, 362-329 \mathrm{ka}$, and $150-100 \mathrm{ka}$ indicate discrete episodes of rhyolite eruption but uneven durations of the episodes and of the quiescent intervals between.

Although precaldera Glass Mountain rhyolites totaled $\sim 100 \mathrm{~km}^{3}$ of magma, Bishop Tuff rhyolite $\sim 650 \mathrm{~km}^{3}$, and ER $\sim 100 \mathrm{~km}^{3}$, the 15 units of younger Long Valley rhyolite add up to less than $8 \mathrm{~km}^{3}$ - similar to the rhyolitic magma volume released at Novarupta (Alaska) on one fine day in June 1912 (Fierstein and Hildreth, 1992; Hildreth and Fierstein, 2012). Despite the near-vertical structure of the stratified metamorphic rocks (Rinehart and Ross, 1964) that compose much of the foundered cauldron block, and despite the complex system of faults transecting the resurgent uplift, there has not been a single eruptive leak on the uplift itself in the last half-million years. Volumetric eruption rate of postcaldera rhyolite was $\sim 1 \mathrm{~km}^{3} / \mathrm{k}$.y. for the 100,000 -year-long ER interval, but it has been only $\sim 0.01 \mathrm{~km}^{3} / \mathrm{k}$.y. since $640 \mathrm{ka}$, a hundredfold decline. Most of the 15 younger rhyolites (and all those younger than $\sim 330 \mathrm{ka}$ ) were crystal-rich, low-temperature magmas, suggesting that prompt eruption of melt separating from crystal mush ceased after the 333-ka crystal-poor Hot Creek flow.

Abundant evidence that the Long Valley rhyolitic system is moribund and that the mantle-driven focus shifted southwestward by $\sim 230$ ka to the Mammoth Mountain trachybasalttrachydacite volcanic field was summarized in Hildreth (2004), Hildreth and others (2014), and Hildreth and Fierstein (2016a).

\section{Mammoth Mafic Volcanic Field}

The central dome complex at Mammoth Mountain was built between $100 \mathrm{ka}$ and $50 \mathrm{ka}$, an interval $\sim 50,000$ years long. The trachydacite edifice accumulated near the center of a distributed field of small monogenetic mafic and intermediate volcanoes that we mapped as 38 separate eruptive units (fig. 9), the eruptive volume of which we estimate to total between 7 and $12 \mathrm{~km}^{3}$. This peripheral monogenetic activity, which principally produced mildly alkalic basalt and its differentiates, began around $230 \mathrm{ka}$ and has continued sporadically into the Holocene. Growth of the trachydacitic Mammoth Mountain edifice thus started up near the middle of the basalt-driven volcanic field, in time as well as in space.
Vents for the monogenetic volcanics peripheral to Mammoth Mountain scatter within an ovate field $\sim 20$ by $10 \mathrm{~km}$ across, which evidently reflects a new, well-circumscribed domain for crustal penetration by postcaldera mantle melts. Before initiation of the Mammoth system, there had been no nearby eruptions other than Long Valley subalkaline rhyolite since the Pliocene.

The 38 peripheral units include 13 basalts, 16 mafic andesites, 6 andesites, and 3 dacites. Nine of them erupted before $\sim 150 \mathrm{ka}$. The oldest exposed unit dated is a phenocryst-poor apron of basaltic trachyandesite lava flows (unit mcl, 190-170 ka) that issued at Canyon Lodge scoria cone (fig. 10) and spread as far as $9 \mathrm{~km}$ northeast and $8 \mathrm{~km}$ east. In the Inyo-4 drill hole near Inyo Craters (Eichelberger and others, 1985, 1988), a set of flows compositionally identical to unit mcl (upper Group II of Vogel and others, 1994) yields a ${ }^{40} \mathrm{Ar} /{ }^{39} \mathrm{Ar}$ age of $186 \pm 2 \mathrm{ka}$. This set is underlain by a 170 -m-thick stack of $\sim 18$ mafic lava flows (Groups II to IV of Vogel), nowhere exposed, for which three ${ }^{40} \mathrm{Ar} /{ }^{39} \mathrm{Ar}$ ages are as old as $233 \pm 4 \mathrm{ka}$ (Hildreth and others, 2014). These unexposed mafic lavas below unit mcl are the oldest known products of the Mammoth volcanic system. Their vents are unknown but certainly buried in the west moat or beneath Mammoth Mountain.

The subsequent eruptive sequence is well-dated (fig. 11) and described in detail by Hildreth and others (2014) and Hildreth and Fierstein (2016a). The interval from $\sim 150$ ka to $\sim 100$ ka was marked by eruption of Long Valley's west moat rhyolites, the first extrusion of phenocryst-rich Mammoth Mountain trachydacite (Dome 2781; $100 \mathrm{ka}$ ), and nine more peripheral mafic and intermediate units. The next interval, from $100 \mathrm{ka}$ to $50 \mathrm{ka}$, included incremental construction of the Mammoth Mountain edifice and eruption of 14 more peripheral units - 5 basalts, 6 mafic andesites, 2 andesites, and 1 dacite. Four of them issued from vents later buried by the edifice. Scoria cones north and south of the edifice produced basaltic aprons that flowed $23 \mathrm{~km}$ and 18 $\mathrm{km}$, respectively, down the caldera's north and south moats (fig. 10). The famous colonnade called Devils Postpile is part of a 110-m-thick intracanyon flow of basaltic trachyandesite $(82 \pm 1 \mathrm{ka})$ preserved discontinuously along the floor of a 7-km-long reach of the Middle Fork of the San Joaquin River.

After the last silicic eruptions of Mammoth Mountain ( $\sim 50 \mathrm{ka})$, there were four mafic eruptions in its periphery as well as extrusion of a chain of five trachydacite lavas in the caldera's northwest moat. A large scoria cone of crystalpoor basaltic trachyandesite, $6 \mathrm{~km}$ north of the summit of Mammoth Mountain, produced a lava-flow apron ( $\sim 33 \mathrm{ka})$ that extends $9 \mathrm{~km}$ northeast to bank against the caldera wall at Crestview. Basaltic lava ( $\sim 31 \mathrm{ka})$ from the subsequently ice-excavated site of Horseshoe Lake banked against the southeast toe of Mammoth Mountain. A northwest-trending set of three glacially ravaged remnants of basaltic trachyandesite scoria, agglutinate, and fountain-fed lava (16 $2 \mathrm{ka})$ is the product of a vent alignment on the caldera's west wall, 5-6 km north of Mammoth Mountain. And the most recent 


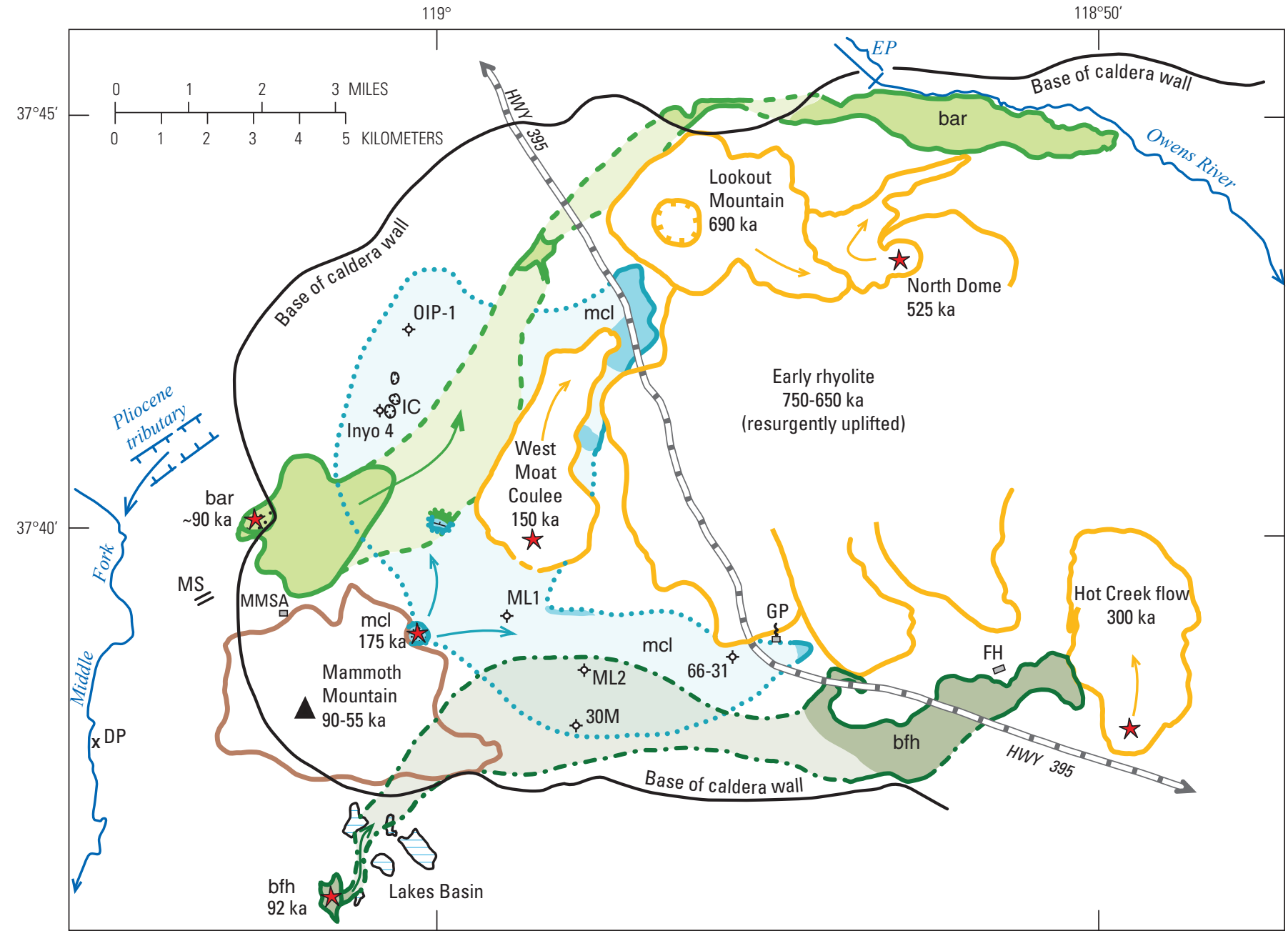

Figure 10. Map of three major mafic lava-flow units in western half of Long Valley Caldera. Because each is extensively covered by younger volcanic and glacial deposits, this diagram is provided to illustrate their original continuity. Colors are strong where unit is exposed but pale where unit is covered or eroded away. Scoria cone at source of each is starred: unit mcl, basaltic trachyandesite of Canyon Lodge ( $175 \mathrm{ka})$ in blue; bfh, basalt of Fish Hatchery ( 92 ka) in gray, and bar, basalt of Arcularius Ranch ( $90 \mathrm{ka})$ in green. Units are described in detail by Hildreth and Fierstein (2016a) and labeled using their schema. Six wells are shown in which one or more of the three mafic units has been identified in drill cores; five more wells located on the resurgently uplifted early rhyolite are mentioned in the concluding section that discusses gephysical unrest; well logs are published in Hildreth and Fierstein (2016a) and Hildreth and others (2017). Long Valley rhyolites outlined in orange predate the three mafic units, except that unit mcl is older than West Moat Coulee ( 150 ka). Trachydacitic Mammoth Mountain is largely younger than the three mafic flows, but its growth began quasi-contemporaneously with the two younger ones. On west rim of caldera, a Pliocene tributary of Middle Fork San Joaquin River (incised through pre-Cenozoic rocks) was filled and permanently blocked by 3.7-to-3.3-Ma stack of basaltic lava flows. Abbreviations: BC, "Blue Chert"; DP, Devils Postpile; EP, East Portal; FH, fish hatchery; GP, geothermal plant; IC, Inyo Craters; MMSA, Main Lodge of Mammoth Mountain Ski Area; MS, Minaret Summit road crossing from Mammoth Lakes township to Devils Postpile.

eruption in the Mammoth periphery is Red Cones ( $8 \mathrm{ka})$, a pair of 120-m-high basaltic scoria cones, 3-4 km southwest of Mammoth Mountain, that jointly produced a $1.2-\mathrm{km}^{2}$ fountainfed apron of thin scoriaceous lavas.

A nonglaciated chain of five comagmatic trachydacite domes and coulees crosses the caldera's northwest moat, 9-10 km north of Mammoth Mountain. All five are glassy and rich in phenocrysts of plagioclase, sanidine, hornblende, and biotite, but they are variably contaminated with mafic enclaves, microdioritic blebs, disequilibrated crystals, and granite-derived xenocrysts, thus ranging in bulk composition from 67.3 to 60.4 percent $\mathrm{SiO}_{2}$. The five vents are roughly aligned and yield nearly identical paleomagnetic directions (Hildreth and others, 2014), suggesting concurrent eruption, but their ${ }^{40} \mathrm{Ar}{ }^{39} \mathrm{Ar}$ ages range from $40 \pm 2 \mathrm{ka}$ to $27 \pm 1 \mathrm{ka}$. 


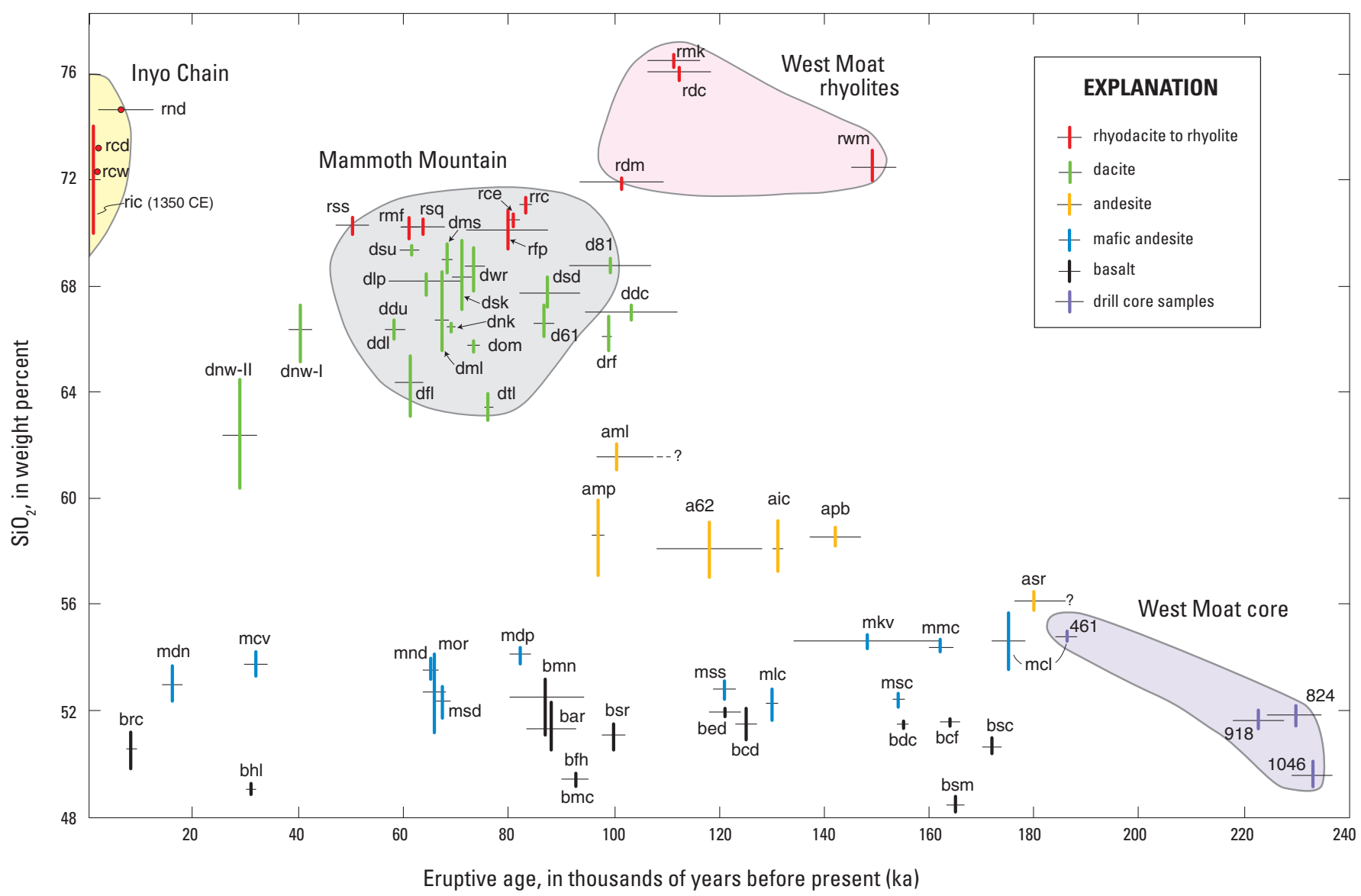

Figure 11. Plot showing silica content versus age: summary for all dated units (230-8 ka) of the Mammoth system-Mammoth Mountain and peripheral monogenetic eruptive units. Also plotted are Holocene Inyo chain and four subalkaline Long Valley rhyolites contemporaneous with alkaline Mammoth system. Unit labels as in Hildreth and Fierstein (2016a). Oldest four ages are core samples of lava flows from Inyo-4 drillhole (Eichelberger and others, 1985), identified by core depth in meters; nowhere exposed at surface, samples represent Groups II, III, and IV of Vogel and others (1994). ${ }^{40} \mathrm{Ar} /{ }^{39} \mathrm{Ar}$ ages from Hildreth and others (2014). Symbol sizes show ranges in unit compositions and uncertainties in ages.

\section{Mammoth Mountain Trachydacite Edifice}

Mammoth Mountain is a pile of overlapping phenocrystrich silicic domes and coulees that extruded from a vent cluster only $2 \mathrm{~km}$ across and spread laterally to form a $5-\mathrm{km}$-wide edifice with $\sim 850 \mathrm{~m}$ of relief (fig. 12). The edifice consists of 22 compositionally and morphologically distinguishable units of effusive lava (fig. 13), among which only five represent more than a single flow. Two additional extrusions of similar trachydacite built off-edifice Domes 2781 and 2861, centered respectively 3.5 and $4.5 \mathrm{~km}$ northeast of the summit of Mammoth Mountain (fig. 13). Every bit of the edifice was ice-covered and thus either surficially scoured or deeply excavated during the late Pleistocene glaciation. The only significant pyroclastic deposit preserved is a plinian pumice-fall deposit as thick as $5 \mathrm{~m}$, exposed north and east of the edifice. These 25 units range in $\mathrm{SiO}_{2}$ content from 63 to 71 percent, and all are mildly alkaline, widely glassy, and generally flowfoliated. All units contain Fe-Ti oxides, biotite, sanidine, and plagioclase, the last being the dominant phenocryst phase in every sample. Hornblende is present in 16 of the units and is the dominant mafic phase in seven of them. Pyroxene microphenocrysts are sparsely present in 20 of the 25 units. Despite uncertainties about glacial losses and depth of its concealed base, Mammoth Mountain erupted no more than $4 \pm 1 \mathrm{~km}^{3}$ of silicic lavas and pyroclastics, including the two off-edifice domes. The moderately alkaline nature of the greater Mammoth system is compared with postcaldera subalkaline rhyolites of the Long Valley system in figure 14.

\section{Post-Mammoth Inyo Chain}

Mammoth Mountain has sometimes been lumped loosely as part of the Inyo Craters volcanic chain, an association we regard as inappropriate and misleading. Although roughly on strike with the rhyolitic Inyo alignment (which is directed by the range-front fault system), the basalt-to-dacite Mammoth array is far broader and much older. The Inyo chain is linear and single-file north-south, whereas the footprint of the 
Mammoth multi-vent array is $10 \mathrm{~km}$ wide from east to west. The Inyo domes extruded along the range-front fault system, which ends beneath the west moat at a left step, jumps $15 \mathrm{~km}$ eastward, and resumes as the Hilton Creek Fault at the caldera's southeastern margin (figs. 1, 2). Mammoth Mountain lies $5 \mathrm{~km}$ outside the caldera's ring fault, banked against the granitic wall of a Pleistocene cirque; it overlies no range-front fault. Moreover, the Mammoth Mountain dome complex ended its period of eruptive activity (100-50 ka) long before inception of Inyo volcanism in the Holocene.

The 10-km-long Inyo chain (Bailey, 1989; Hildreth, 2004) consists of seven rhyolitic lava flows and domes, several phreatic craters, and a composite apron of pyroclastic fall and flow deposits (Miller, 1985; Sampson and Cameron, 1987; Nawotniak and Bursik, 2010). The oldest unit is North Deadman dome $\left(\sim 0.04 \mathrm{~km}^{3}\right)$, undated but probably mid-Holocene, followed by Wilson Butte $\left(\sim 0.05 \mathrm{~km}^{3}\right)$, which is thought to have erupted $\sim 1.3 \mathrm{ka}$. Both domes are aphyric glassy rhyolite. Wilson Butte (76.6 percent $\mathrm{SiO}_{2}$ ) is similar compositionally and petrographically to the Mono Craters domes (Kelleher and Cameron, 1990) and should be called a Mono dome were it not for its position on the north-south linear trend of the Inyo chain rather than the arcuate trend (fig. 1) of the Mono chain. North Deadman dome (74.7 percent $\mathrm{SiO}_{2}$ ) is compositionally intermediate between Wilson Butte and the crystal-poor lower-silica rhyolite (Sampson and Cameron, 1987) that dominated the youngest Inyo eruptive episode in 1350 C.E. Two phenocryst-poor mini-domes (each $<0.001 \mathrm{~km}^{3}$ ) just north and south of the large Glass Creek flow erupted after Wilson Butte but before the 1350 C.E. eruption, products of which they compositionally resemble (Sampson and Cameron, 1987).

Injection of the Inyo dike (Eichelberger and others, 1985) in late summer of 1350 C.E. (Millar and others, 2006) led to sequential eruption of the Deadman Creek, Obsidian, and Glass Creek flows, each preceded by substantial pyroclastic outbursts (Miller, 1985), the last of which was followed by phreatic eruptions at nearby Inyo Craters (Mastin, 1991).

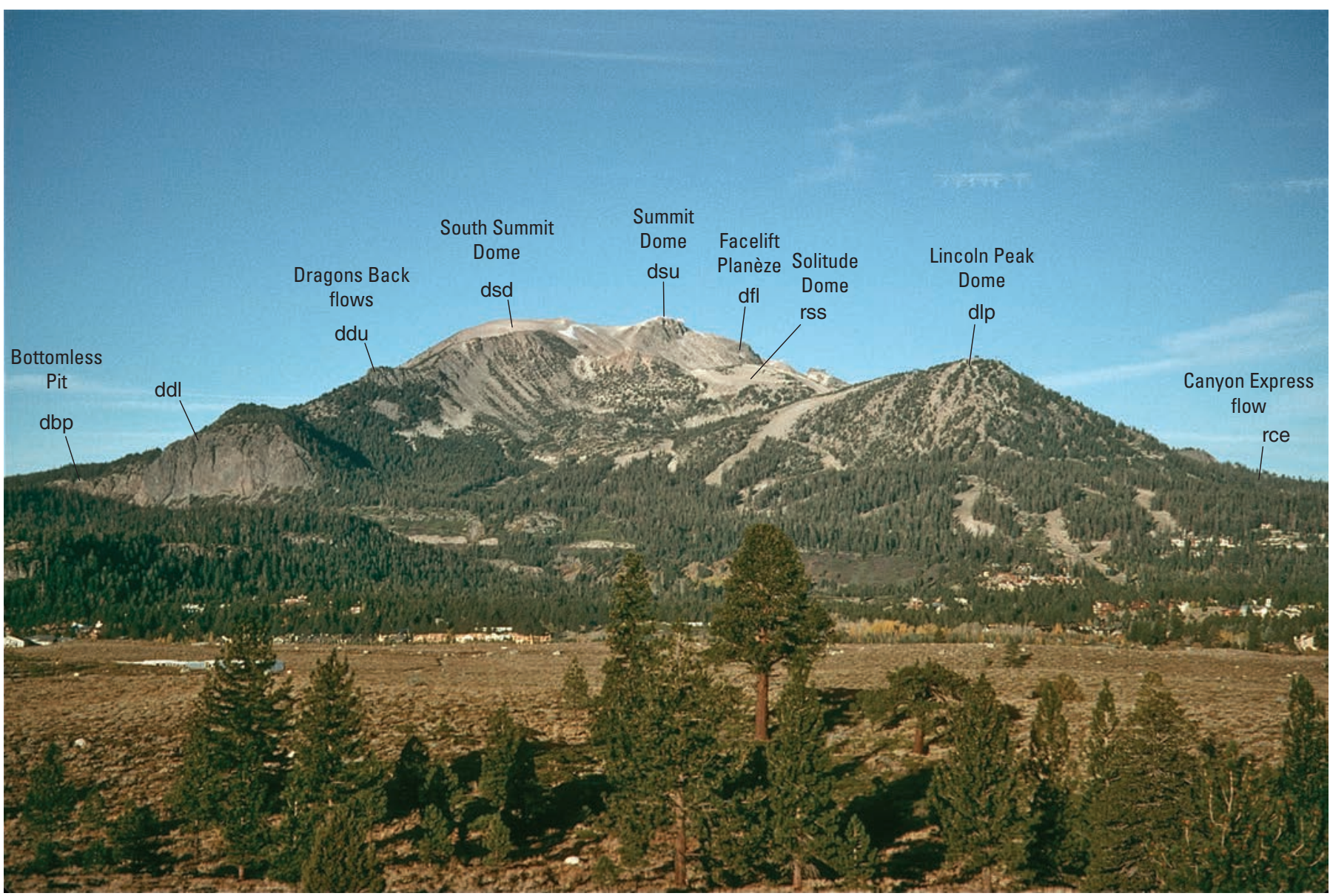

Figure 12. Photo of east side of Mammoth Mountain, showing steep former glacial headwall and numerous cleared ski runs. Several extrusive units are identified, as described by Hildreth and Fierstein (2016a). Lower and upper Dragons Back flows (units ddl, ddu) and Solitude Dome (rss) are youngest eruptive units on edifice $(\sim 58-50 \mathrm{ka}) .{ }^{40} \mathrm{Ar} /{ }^{39} \mathrm{Ar}$ ages include $64 \pm 7 \mathrm{ka}$ for Lincoln Peak dome (dlp); $61.4 \pm 2$ ka for Summit Dome (dsu); and $87 \pm 6$ ka for South Summit Dome (dsd), one of oldest and largest units on edifice. Subhorizontal roadcut across center of image is Lake Mary Road, which links residential neighborhood of Mammoth Lakes (at lower right) to Lakes Basin (out of view to left). Housing development at far right is built on forested coulee of rhyodacitic unit rce ( 80 ka). Total relief in image $\sim 970 \mathrm{~m}$. View is westward from moraine crest near Sherwin Creek. 


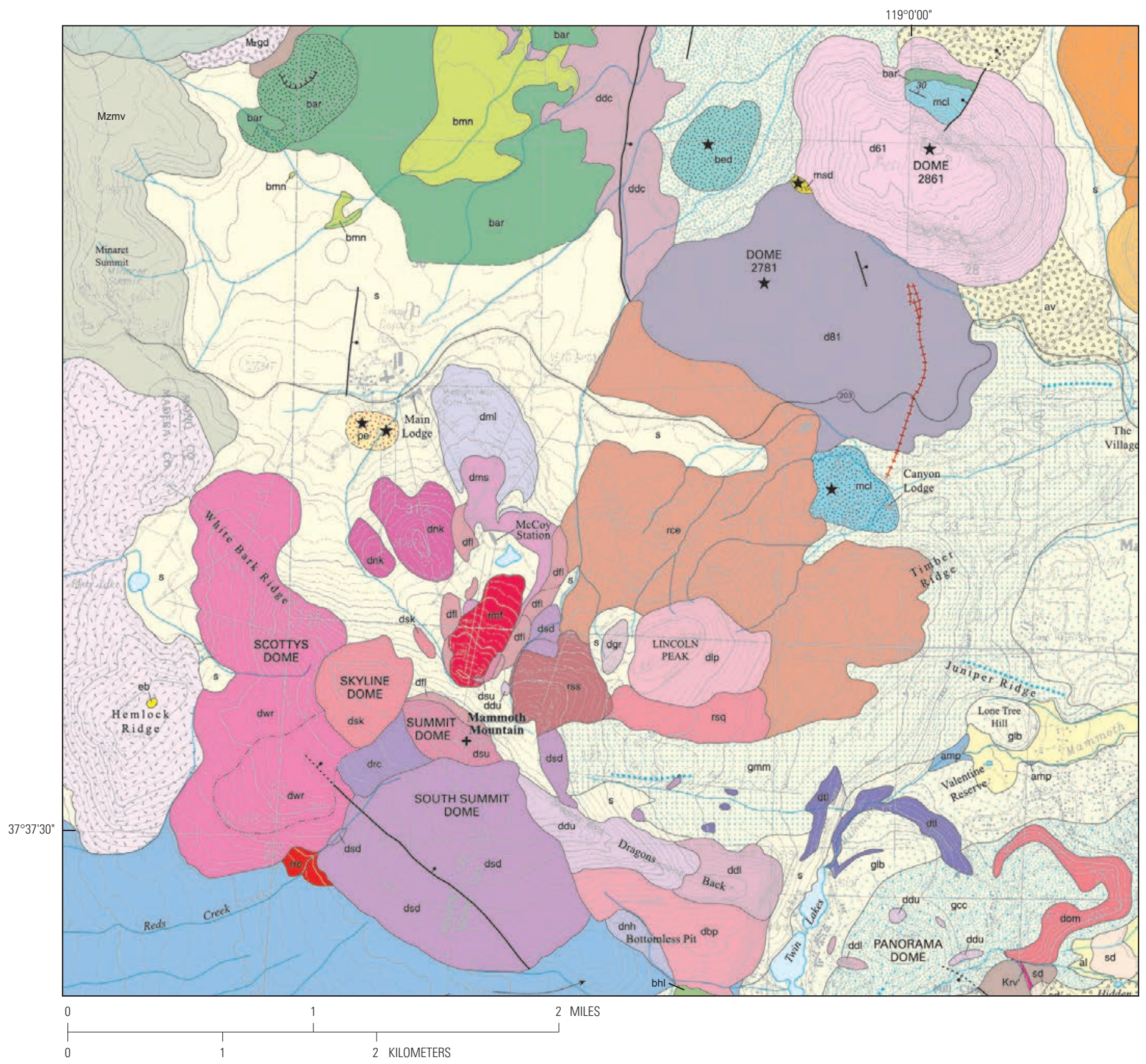

\section{EXPLANATION}

Wu Volcanic crater or partial crater rim

+ Surficial rift or fissure on lava flow (not a vent)

$\longrightarrow$ Lava flow direction

$+\quad$ Normal fault; dotted where concealed

... Moraine crests

$\star \quad$ Volcanic vent

al alluvium

amp trachydacite of Mammoth Pass

av rockfall avalanche deposits

trachybasalt of Arcularius Ranch

trachybasalt of Arcularius Ranch

basalt east of Dry Creek

basalt of Horseshoe Lake

trachybasalt northeast of Minaret Summit

explosion breccia

trachydacite of Dome 2861

trachydacite of Dome 2781

trachydacite of bottomless Pit trachydacite of Dry Creek trachydacite of lower Dragons Back trachydacite of upper Dragons Back trachydacite of Gold Rush Express trachydacite of Face Lift trachydacite of Lincoln Peak trachydacite of Main Lodge Coulee trachydacite of McCoy Station trachydacite north of Horseshoe Lake trachydacite of North Knob trachydacit of Old Mammoth trachydacite of upper Reds Creek trachydacite of South Summit Dome trachydacite of Skyline Dome trachydacite of Mammoth Mountain summit trachydacite of Twin Lakes outlet trachydacite of White Bark Ridge till of Cold Water Canyon till derived from Lakes Basin

till derived from Mammoth Mountain

Mono Creek Granite of the John Muir Intrusive Suite

Round Valley Peak Granodiorite

basaltic trachyandesite of Canyon Lodge

basaltic trachyandesite of scoria southeast of Dry Creek granodiorite northeast of Minaret Summit

metavolcanic rocks of Ritter Range pendant

phreatic ejecta

metasedimentary rocks of Mount Morrison pendant

alkali rhyodacite of Canyon Express

alkali rhyodacite of Mammoth Mountain fumarole

alkali rhyodacite of Reds Creek

alkali rhyodacite of Quicksilver ski run

alkali rhyodacite of Solitude ski run

surficial deposits, undivided

spring deposits

trachybasalt of Deadman Pass 
Figure 13. Geologic map of Mammoth Mountain. Exposed on the edifice are 22 discrete extrusive units, of which only 5 consist of more than one lava flow. Of these, 17 are phenocryst-rich hornblende-biotite trachydacites (63-69 percent $\mathrm{SiO}_{2}$ ) and 5 are alkalic rhyodacites (70-71 percent $\left.\mathrm{SiO}_{2}\right)$ that carry only half as many crystals. Domes 2781 and 2861 , just northeast of the main pile, are trachydacites similar to those of the edifice. Fissure cutting Dome 2781 (red hatched line) is the so-called "Earthquake Fault" of Benioff and Gutenberg (1939). Unit labels are identified in explanation; units are fully described in Hildreth and Fierstein (2016a). Eruptive ages range from $\sim 100 \mathrm{ka}$ to $\sim 50 \mathrm{ka}$. In blue and green are basaltic and intermediate units that slightly predate edifice trachydacites. Coulee unit ddc ( 103 ka) and extensive apron unit amp ( $\sim 97 \mathrm{ka})$, both phenocryst-poor, erupted from vents later covered by the edifice. Canyon Lodge scoria cone (unit mcl; $\sim 175 \mathrm{ka}$ ) was partly overrun by rhyodacitic coulee, unit rce ( $20 \mathrm{ka})$. Scoria cone northeast of Minaret Summit ( $90 \mathrm{ka}$; fig. 17) produced basaltic apron units bmn and bar, the latter extending as far as $23 \mathrm{~km}$ from vent (Stop 27). Steep trachydacite Dome 2861 lifted slab of mafic lavas (units $\mathrm{mcl}$ and bar) on its roof. Pale yellow surficial deposits include till, colluvium, and 1350 C.E. pumice-fall deposits. Dotted blue lines are moraine crests. Pair of stars southwest of Main Lodge marks late Holocene phreatic craters, surrounded by apron of phreatic ejecta. Map extracted and modified from Hildreth and Fierstein (2016a).

$\boldsymbol{A}$

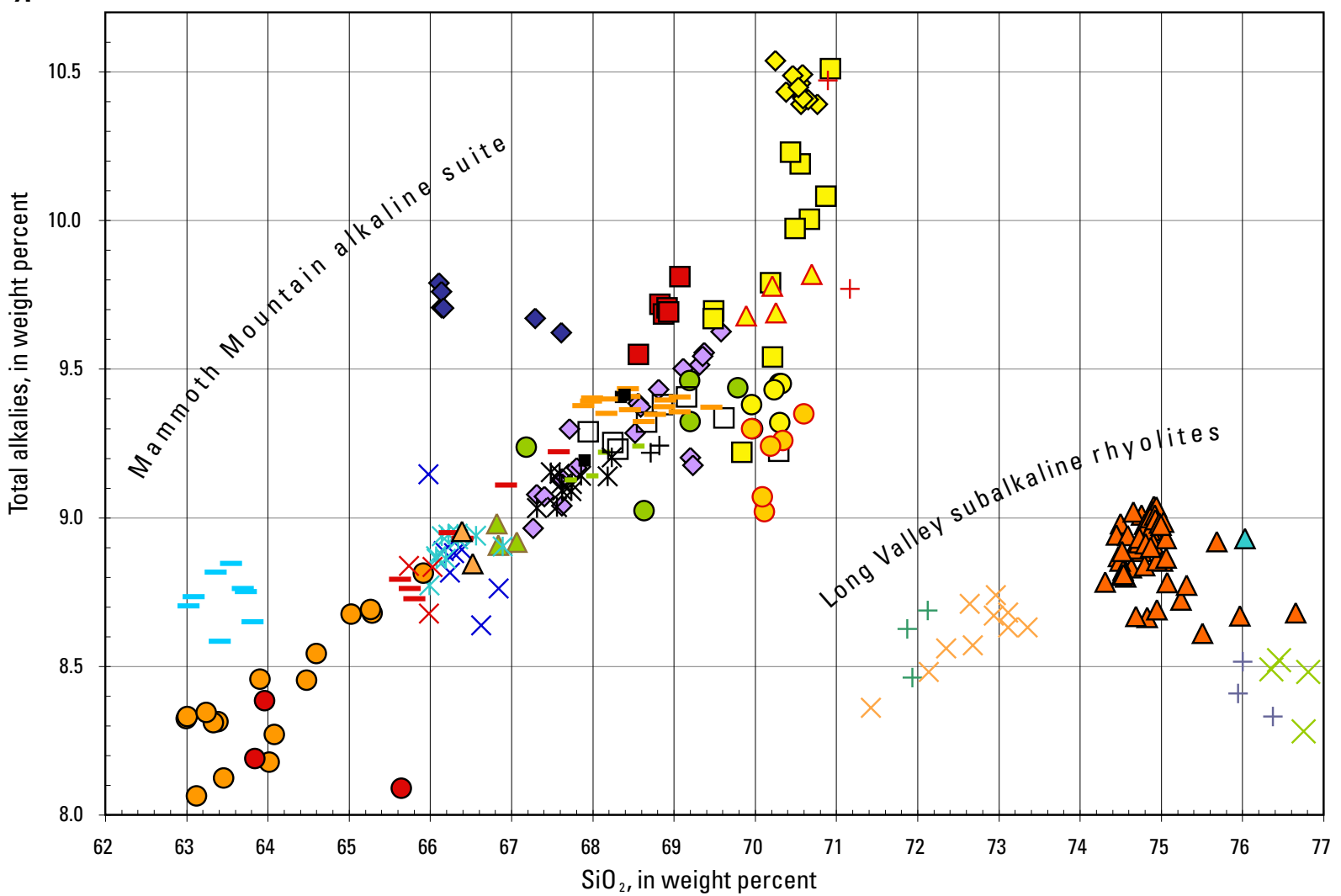

\section{EXPLANATION}

$\begin{array}{ll}\Delta d b p & \text { trachydacite of bottomless Pit } \\ X \mathrm{ddl} & \text { trachydacite of lower Dragons Back } \\ \text { X ddu } & \text { trachydacite of upper Dragons Back } \\ \text { Odfl } & \text { trachydacite of Face Lift } \\ +\mathrm{dgr} & \text { trachydacite of Gold Rush Express } \\ =\mathrm{dlp} & \text { trachydacite of Lincoln Peak } \\ -\mathrm{dml} & \text { trachydacite of Main Lodge Coulee } \\ \triangle \mathrm{dms} & \text { trachydacite of McCoy Station } \\ \mathbf{d} \mathrm{dnh} & \text { trachydacite north of Horseshoe Lake } \\ \Delta \mathrm{dnk} & \text { trachydacite of North Knob } \\ \mathbf{X} \text { dom } & \text { trachydacite of Old Mammoth }\end{array}$

$\begin{array}{ll}\Delta r m f & \text { alkalic rhyodacite of Mammoth Mountain fumarole } \\ + \text { rrc } & \text { alkalic rhyodacite of Reds Creek } \\ \text { Orsq } & \text { alkalic rhyodacite of Quicksilver ski run } \\ \text { Orss } & \text { alkalic rhyodacite of Solitude ski run } \\ + \text { rdc } & \text { rhyolite of Dry Creek Dome } \\ \Delta \text { rer } & \text { early rhyolite of Bailey } \\ + \text { rdm } & \text { rhyolite of Deer Mountain } \\ \Delta \text { rhc } & \text { rhyolite of Hot Creek flow } \\ \times \text { rmk } & \text { rhyolite of Mammoth Knolls } \\ \times \text { rwm } & \text { rhyolite of West Moat Coulee }\end{array}$

* dsd trachydacite of South Summit Dom

Odsk trachydacite of Skyline Dome

$\square$ dsu trachydacite of Mammoth Mountain summit

- dtl trachydacite of Twin Lakes outlet

- dwr trachydacite of White Bark Ridge

$\checkmark \mathrm{d} 61 \quad$ trachydacite of Dome 2861

$\square$ d81 trachydacite of Dome 2781

$\checkmark$ rce alkalic rhyodacite of Canyon Express

$\square$ rfp alkalic rhyodacite pumice fall of Hwy 203

Figure 14. Total alkalies $\left(\mathrm{Na}_{2} \mathrm{O}+\mathrm{K}_{2} \mathrm{O}\right)$ versus $\mathrm{SiO}_{2}$ contents in weight percent for $(A)$ Mammoth Mountain dome complex and $(B)$ peripheral units of wider Mammoth magmatic system. Unit labels as in Hildreth and Fierstein (2016a). Also plotted in panel $A$ are data for six units of subalkaline Long Valley system, four of which erupted 150-100 ka, contemporaneous with Mammoth system. Alkaline/ subalkaline boundary in panel B follows LeBas and others (1986). Dashed enclosure outlines field of Mammoth Mountain trachydacites shown in panel $A$. 


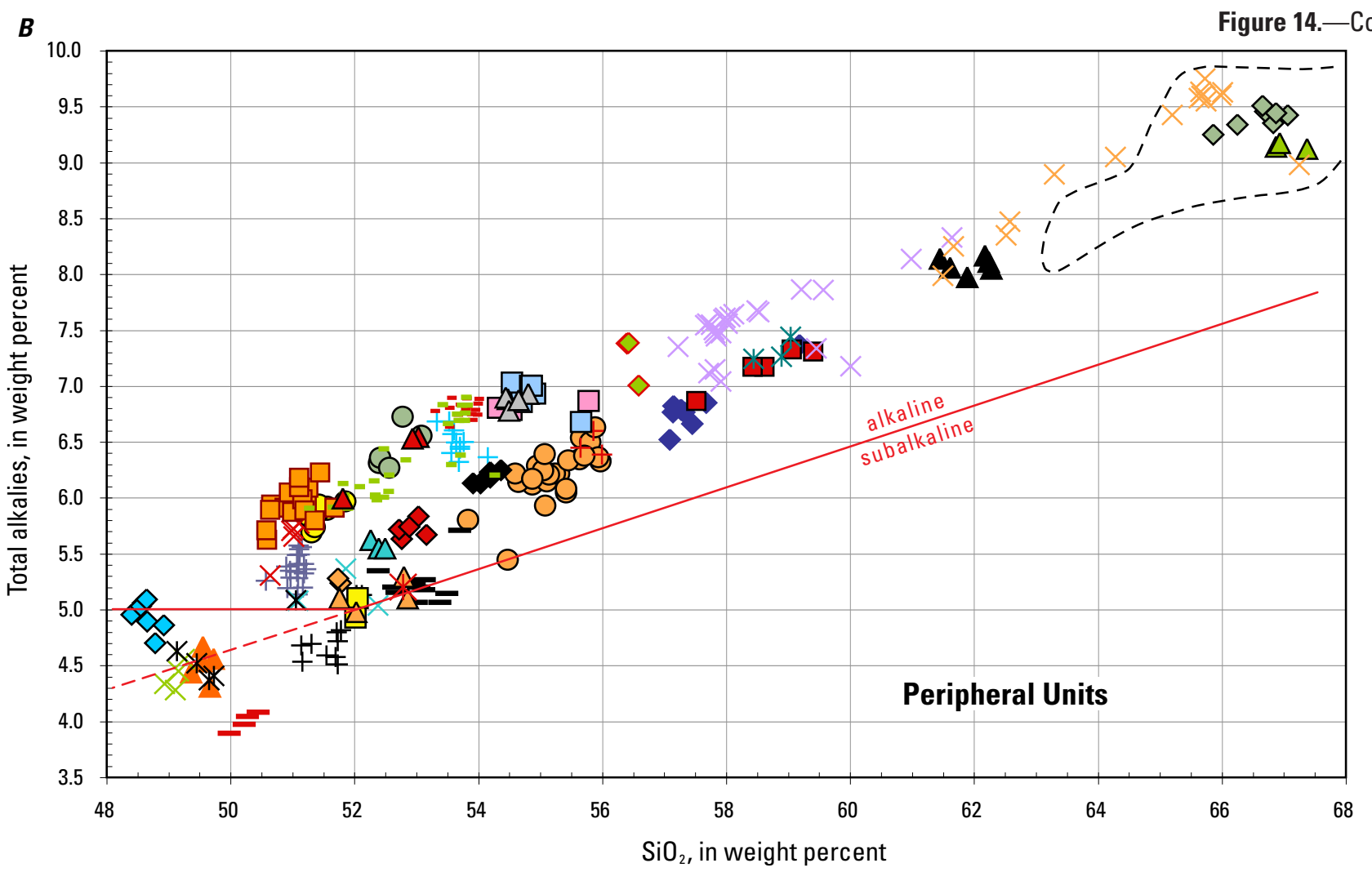

$\begin{array}{ll}\text { a62 } & \text { trachyandesite of Cone } 2962 \\ \square \text { aic } & \text { trachyandesite of Inyo Craters } \\ \mathbf{\Delta} \text { aml } & \text { trachyandesite of McLeod Lake } \\ \times \text { amp } & \text { trachyandesite of Mammoth Pass } \\ \text { * apb } & \text { trachyandesite of Pumice Butte } \\ \diamond \text { asr } & \text { trachyandesite of Shady Rest Campground } \\ + \text { bar } & \text { trachybasalt of Arcularius Ranch } \\ \times \text { bar' } & \text { trachybasalt of Arcularius Ranch } \\ + \text { bcd } & \text { basalt of Casa Diablo Hot Springs } \\ \diamond \text { bcf } & \text { trachybasalt south of Crater Flat } \\ \square \text { bed } & \text { basalt east of Dry Creek } \\ \Delta \text { bfh } & \text { basalt of Fish Hatchery } \\ \times \text { bhl } & \text { basalt of Horseshoe Lake }\end{array}$

\section{EXPLANATION}

* bmc basalt of Mammoth Crest

Obmn trachybasalt northeast of Minaret Summit

Obmn' trachybasalt northeast of Minaret Summit

- brc basalt of Red Cones

$X$ bsc trachybasalt of Sherwin Creek Road

$\diamond$ bsm basalt of Sawmill Cutoff

$\square$ bsr trachybasalt of Shady Rest

$\triangle d d c$ trachydacite of Dry Creek

$X$ dnw trachydacite of Northwest Moat

$\diamond$ drf trachydacite of Rainbow Falls

$\mathrm{O} \mathrm{mcl}$ basaltic trachyandesite of Canyon Lodge

+ mcv basaltic trachyandesite south of Crestview

$+\mathrm{mdm}$ basaltic trachyandesite of Deer Mountain
- mdn basaltic trachyandesite NE of Deadman Pass

- mdp basaltic trachyandesite of Devils Postpile

$\square$ mic mafic pyroclastic deposit of Inyo Craters

$\square$ mkv basaltic trachyandesite of Knolls Vista

$\triangle \mathrm{mlc}$ basaltic trachyandesite of lower Laurel Creek

$\Delta \mathrm{mmc}$ basaltic trachyandesite of Mammoth Creek

- mnd basaltic trachyandesite NW of Dry Creek

- mor basaltic trachyandesite of Owens River Road

$\triangle \mathrm{msc}$ basaltic trachyandesite of Sawmill Cutoff

$\Delta$ msd basaltic trachyandesite scoria SE of Dry Creek

* msj basaltic andesite of Scenic Loop Road junction

$\diamond \mathrm{mss}$ basaltic trachyandesite of upper Soda Springs
Total magma volume erupted during the 1350 C.E. episode was estimated by Miller (1985) to be $0.4 \mathrm{~km}^{3}$ as lava, $0.17 \mathrm{~km}^{3}$ as fallout, and $>0.05 \mathrm{~km}^{3}$ as pyroclastic density currents.

Compositionally, the mid-14th century Inyo eruption was extraordinarily complex (Sampson and Cameron, 1987; Vogel and others, 1989). As summarized by Hildreth (2004), at least four discrete magmas were confluent during the eruption: (1) crystal-poor rhyolite like that of Mono Craters; (2) crystalrich Long Valley rhyolite like that of some 150-100-ka west moat domes; (3) trachydacite like that of the 40-27-ka chain of flows and domes on the caldera's northwest margin; and (4) andesitic magmatic inclusions $\left(\sim 60\right.$ percent $\left.\mathrm{SiO}_{2}\right)$ found chilled in two of the 1350 C.E. lava flows (Varga and others, 1990). The compositional and petrographic similarity of the crystal-rich component to the nearby Long Valley rhyolite of Deer Mountain was pointed out by Sampson and Cameron (1987). Moreover, Reid and others (1997) identified, in both 1350 C.E. crystal-rich Inyo lava and 115-ka Deer Mountain lava, zircon populations with crystallization ages that cluster around $230 \mathrm{ka}$. Residual or thermally rejuvenated Long Valley magmatic crystal mush appears to have been involved - and $230 \mathrm{ka}$ is exactly when basaltic magmatism of the greater Mammoth system began in the western part of the caldera.

Figure 15 gives some key compositional contrasts between products of the Long Valley system (2.2 Ma to Holocene) and the more alkaline Mammoth system (230 ka to Holocene).

\section{Long Valley Chronology: A Summary Timeline}

Basement rocks are Paleozoic metasedimentary rocks, Mesozoic metavolcanic rocks, and Mesozoic granitoid plutons. No Paleogene rocks have been identified in the Long 

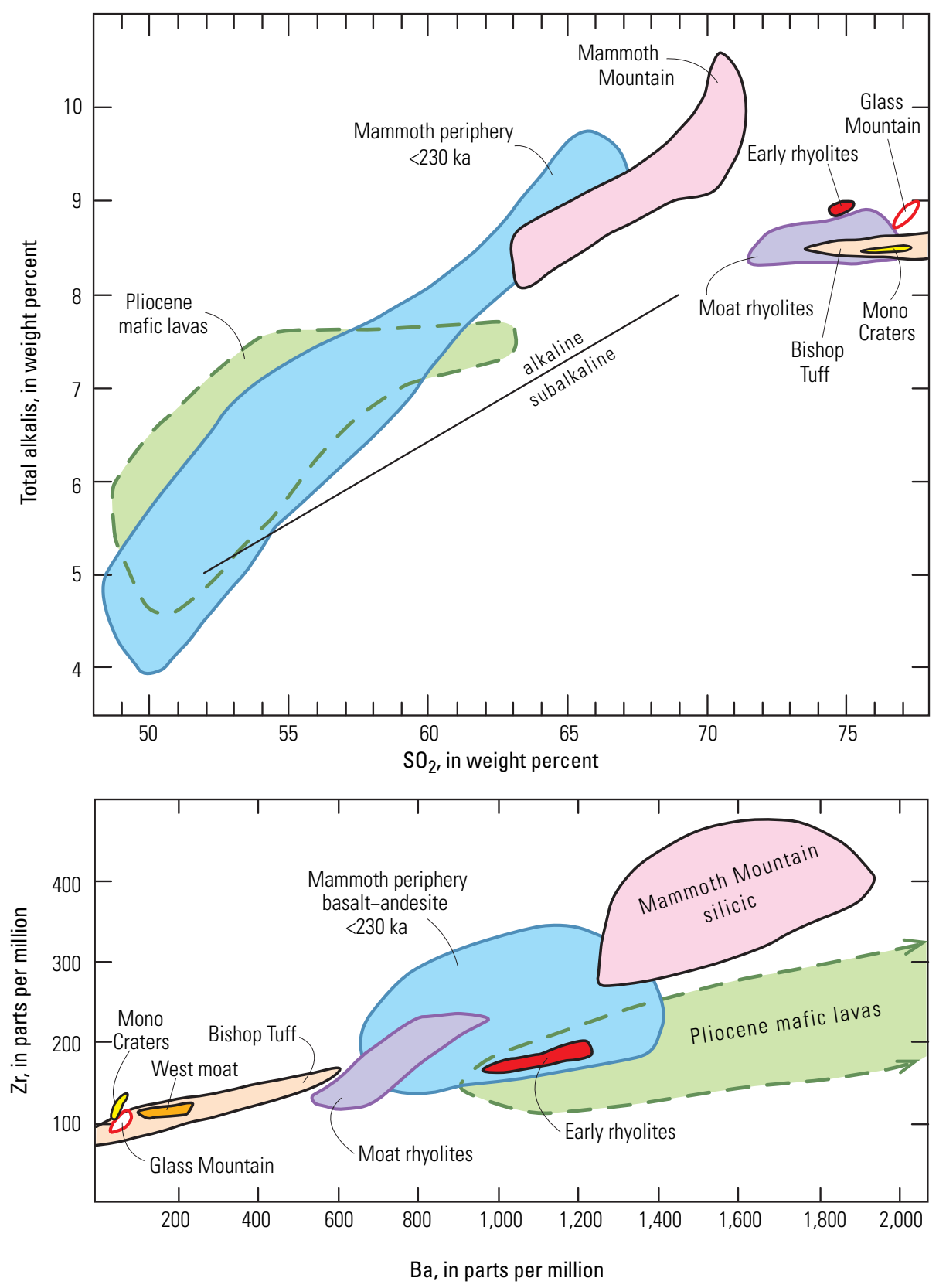

Figure 15. Top, plot of total alkalies $\left(\mathrm{Na}_{2} \mathrm{O}+\mathrm{K}_{2} \mathrm{O}\right)$ versus $\mathrm{SiO}_{2}$ (in weight percent) and bottom, plot of $\mathrm{Zr}$ versus $\mathrm{Ba}$ (in parts per million), comparing Long Valley and Mammoth suites. Alkaline/subalkaline divider after LeBas and others (1986). Bishop Tuff data from Hildreth and Wilson (2007); Glass Mountain data from Metz and Mahood (1985, 1991); Mono Craters data from Kelleher and Cameron (1990); early rhyolite data from Hildreth and others (2017); Mammoth, Pliocene, and moat rhyolites data from Hildreth and Fierstein (2016a). For moat rhyolites, low-Ba field represents Dry Creek and Mammoth Knolls Domes in west moat; higher-Ba field is for all 12 other rhyolite extrusions (north-central chain, southeast moat, and other west moat).
Valley region. Neogene volcanic rocks are widespread north and east of Mono Lake, but near Long Valley only two prePliocene vents have been identified. Magmatism around Long Valley resumed about $4 \mathrm{Ma}$ and has been essentially continuous since. The Pliocene episode of magmatism here was part of a regional pulse of moderately alkalic mafic volcanic activity, most active between 4 and $3 \mathrm{Ma}$, along what is today the Sierra Nevada and its eastern borderlands, extending from Mono Basin $250 \mathrm{~km}$ southward to the Coso Range (Manley and others, 2000).

4.0-2.6 Ma Eruption of widespread mildly alkalic basalts and trachyandesites. A zone with many vents is continuous from the Sierra Nevada in the west, extending across the north side of Long Valley, to the Adobe Hills in the northeast. A few vents are also scattered to the east and southeast of the later site of the caldera (fig. 3 ).

3.75 Ma Basalt of The Buttresses. A stack of phenocrystrich lavas with $475 \mathrm{~m}$ of preserved relief filled the north-south reach of the Middle Fork of the San Joaquin River to the present-day floor of its granite canyon, showing that the gorge was as deep in the Pliocene as it is today.

\section{7-3.3 Ma Paleotributary of Middle Fork filled by $450 \mathrm{~m}$} stack of basalt flows. A channel drained from the later site of Mono Basin via Crestview and flowed southwest across what is now the main drainage divide, $\sim 1 \mathrm{~km}$ south of Deadman Pass. The stack of numerous basaltic lavas completely filled the channel and diverted the drainage southeast toward the Owens River. The blockage predated range-front faulting. 


\subsection{Ma Small basaltic shield filled and blocked Owens} River Gorge. Owens River flowed from the later site of Mono Basin across what is now the eastern part of the caldera and by the middle Pliocene cut a gorge $200 \mathrm{~m}$ deep through a ridge of Triassic granodiorite just southeast of the later site of the caldera. Eruption near the gorge rim of a basaltic shield at 3.3 Ma completely filled a 5-km-long reach of the gorge, diverting the river into Rock Creek. At $767 \mathrm{ka}$, the rest of Owens River Gorge was filled by caldera-forming ignimbrite, the Bishop Tuff. Neither the basalt-filled segment nor any part of the 30-km-long gorge were reincised until after $150 \mathrm{ka}$ (Hildreth and Fierstein, 2016b).

\subsection{5-2.6 Ma Trachydacite and trachyandesite domes} and pyroclastic flows. At least 16 lava domes of intermediate composition, most of them containing hornblende and biotite, erupted in a zone northwest and north of the later site of the caldera (fig. 3). One additional trachydacite (3.6 Ma) is preserved high on the south rim of the caldera. Some northwestern domes were preceded by pumiceous pyroclastic flows and accompanied by dome-collapse block-and-ash flows.

\subsection{Ma Onset of range-front faulting northwest and} southeast of Long Valley. Trachydacite pyroclastic flows $(2.6 \mathrm{Ma})$ northwest of the caldera were emplaced on a lowrelief surface of basement rocks that was only later downfaulted. Basalts of McGee Mountain (2.6 Ma) southeast of the caldera were also emplaced on a low-relief surface adjacent to what later became a 900-m-high Hilton Creek Fault scarp. Subsidence of Owens Valley and Mono Basin, to the south and north, was also underway by $2.5 \mathrm{Ma}$.

\section{2-0.8 Ma Glass Mountain high-silica rhyolites. As} many as 60 eruptions released as much as $100 \mathrm{~km}^{3}$ of rhyolitic magma as region-wide fallout, extensive pyroclastic flows, and more than 50 extrusive lava domes and flows (fig. 5 ). The rhyolite pile is exposed to a thickness as great as $1,135 \mathrm{~m}$ where cut by the caldera's northeast wall (fig. 4).

900-866 ka Sherwin glaciation in the Sierra Nevada. Inferred to represent Marine Isotope Stage (MIS) 22, the first high-amplitude cold interval at the "Mid-Pleistocene Climatic Revolution" (Berger and others, 1993; Muttoni and others, 2003), the Sherwin ice advanced farther than that of any other glacial episode in the Sierra Nevada (Blackwelder, 1931). The piedmont lobe that spread out from the mouth of Rock Creek deposited a sheet of till as thick as $200 \mathrm{~m}$ that extends as far as $8 \mathrm{~km}$ eastward, crossing Owens River Gorge.

767 ka Caldera-forming eruption of the Bishop Tuff. A plinian eruption began in the south-central part of the subsequent caldera and released as much as $100 \mathrm{~km}^{3}$ of magma as continental-scale fallout, which is preserved as far as 1,800 $\mathrm{km}$ east. About $200 \mathrm{~km}^{3}$ more magma produced variably welded ignimbrite as radial outflow sheets, and $\sim 350 \mathrm{~km}^{3}$ more was trapped as welded tuff that filled the depression, which subsided 2-3 km. Deposition of fallout and ignimbrite were concurrent throughout the multi-package sequence, which continued for 5-6 days (fig. 6). As the roof of the magma chamber failed, propagating ring faults released zoned pyroclastic deposits that varied sectorially in proportions of juvenile pumice compositions and in suites of ventderived lithic fragments. The ring-faulted depression is 12 by $22 \mathrm{~km}$, but syneruptive slumping and secular erosion of the walls enlarged the topographic caldera to its present-day 17 by $32 \mathrm{~km}$ dimensions.

750-640 ka Early postcaldera rhyolites. About $100 \mathrm{~km}^{3}$ of phenocryst-poor high-silica rhyolite was erupted in the west-central part of the caldera during the $\sim 125$-kyr interval after the caldera-forming event. Ignimbrite predominated, but 11 separate extrusive lavas are exposed. The assemblage is as thick as $622 \mathrm{~m}$ and rests directly on intracaldera Bishop Tuff, as revealed in numerous geothermal exploratory wells. The "early rhyolite" is compositionally similar to last-erupted parts of the Bishop Tuff (fig. 8), although richer in Ba and Zr and devoid of quartz and sanidine. Some units are aphyric; others have $\sim 1$ percent plagioclase, biotite, and orthopyroxene. Most of the early rhyolite was later uplfted by structural resurgence, centrally by more than $400 \mathrm{~m}$.

570-500 ka North-central rhyolite chain. A chain of three high-silica rhyolite domes and one extensive lava flow erupted through the early rhyolite in the northeastern sector of the resurgent uplift. In contrast to the early rhyolite, these lavas are rich in hornblende, biotite, plagioclase, quartz, and sanidine. The 570-ka lava flowed downhill into the caldera's north moat, showing that resurgent uplift was by then underway and probably largely complete. The flow and domes contain chilled mafic enclaves, unlike most subsequent Long Valley rhyolites. The total volume erupted was only $\sim 1 \mathrm{~km}^{3}$, a drastic reduction from all preceding stages of Long Valley rhyolite magmatism.

362-329 ka Southeastern rhyolite cluster. Six separate high-silica rhyolite lavas erupted in the caldera's southeast moat, all of them extruding through sediments then accumulating in a large caldera lake. Two are phenocryst-rich and similar to the north-central chain, but four are poor in phenocrysts - including the Hot Creek flow (333 ka), which greatly dominates the total eruptive volume of $\sim 1.5 \mathrm{~km}^{3}$. Littoral sandstone and tufa subsequently lapped or partly buried all of them.

230 ka Onset of postcaldera mafic eruptions. There had been no mafic volcanism in the Long Valley region since 2.6 Ma, except for enclaves in the north-central chain and rare enclaves in the early rhyolite. Starting about $230 \mathrm{ka}$ and confined to the caldera's west moat and the adjacent Sierra Nevada, as many as 38 vents have produced basaltic and intermediate lavas and scoria cones in a compact area surrounding the trachydacitic edifice of Mammoth Mountain. There has since been at least one such peripheral eruption in almost every 10,000-year interval (fig. 11). Eruptions have been volumetrically modest but essentially continuous since $230 \mathrm{ka}$. The most recent mafic eruption produced the Red Cones at $8 \mathrm{ka}$. 
213 ka Pringle Falls geomagnetic excursion recorded in caldera lake sediment. Soon after caldera collapse, an intracaldera lake began filling, permitting transport of icebergrafted erratic boulders from the Sierra Nevada and their deposition upon early rhyolite lavas as old as $700 \mathrm{ka}$ (Hildreth and Fierstein, 2016b). The lake persisted throughout the middle Pleistocene, filling with more than $700 \mathrm{~m}$ of sediment that rests atop the intracaldera Bishop Tuff. Lake deposits include a littoral facies of shingle and pebbly sandstone and a central facies of siltstone and unconsolidated silt. A geomagnetic excursion was identified in the top few meters of the lake silt in central Long Valley (Liddicoat and others, 1998) and correlated with a complex excursion first defined at Pringle Falls, Oregon.

\section{0-130 ka Marine Isotope Stage 6, Tahoe glaciation} in the Sierra Nevada. Poorly preserved moraines known as "Casa Diablo Till" were deposited on both sides of Mammoth Creek as far downstream as $\sim 1 \mathrm{~km}$ beyond the outermost moraines of MIS 2 (Tioga) age. Stage 6 moraines are well preserved at Convict, McGee, Hilton, and Rock Creeks south of the caldera and near June Lake northwest of it.

\section{0-172 ka Beginning of caldera lake regression. A} 180-ka lava flow in the caldera's south moat is lapped by lake sediment, but another lava flow less than $1 \mathrm{~km}$ away, which is $20 \mathrm{~m}$ lower in elevation and ${ }^{40} \mathrm{Ar} /{ }^{39} \mathrm{Ar}$-dated at $172 \mathrm{ka}$, shows no evidence of lake sediment or wave erosion.

\section{0 ka Rhyolite eruption of West Moat Coulee and end} of caldera lake sedimentation. A 5-km-long coulee of lowsilica rhyolite (72-73 percent $\mathrm{SiO}_{2}$ ) erupted in the southwest part of the caldera from a vent marked by a 50-m-high halfring of pumiceous ejecta. The phenocryst-rich lava contains sanidine, plagioclase, quartz, biotite, hornblende, and Fe-Ti oxides. Tephra layers in the topmost silt deposits of the caldera lake, $17 \mathrm{~km}$ northeast of the vent, are correlated exclusively with the 150-ka coulee (and not with any of the other Long Valley rhyolites). The tephra-bearing silt is closely overlain by shoreface sand and then by fluvio-lacustrine pebbly alluvium, thus indicating extinction of the lake at about this time.

142 ka; 118 ka Trachyandesite scoria cones at Pumice Buttes. Two large cones, each $150 \mathrm{~m}$ high, erupted $7-8 \mathrm{~km}$ south of Mammoth Mountain. Built atop a high interfluve, the cones and their lava-flow aprons largely avoided erosion by the MIS 2 glaciers that filled adjacent canyons.

\section{5 ka Eruption of youngest basaltic lava flow cut by} graben faults on the uplift. Extensional faults that transect the western flank of the resurgent uplift cut this flow near the Casa Diablo geothermal plant. The same set of faults cuts other mafic lava flows that are ${ }^{40} \mathrm{Ar} /{ }^{39} \mathrm{Ar}$-dated to be $165 \mathrm{ka}$ and 170-190 ka elsewhere along the graben.

\section{5-100 ka Eruption of rhyolite domes in the west moat.} Deer Mountain (72 percent $\mathrm{SiO}_{2}$ ), Dry Creek Dome and Mammoth Knolls Dome (both 76 percent $\mathrm{SiO}_{2}$ ) erupted in the caldera's west moat, apparently along or near its ring-fault zone.
All are phenocryst-rich, Deer Mountain being the richest, each containing sanidine, plagioclase, quartz, biotite, hornblende, zircon, and Fe-Ti oxides.

121-82 ka Four sets of lava flows along floor of Middle Fork of San Joaquin River. Oldest of the four is a basaltic trachyandesite that erupted at a scoria cone near upper Soda Springs. The trachydacite of Rainbow Falls and the trachyandesite of Mammoth Pass both erupted at the later site of Mammoth Mountain. Youngest of the four is the basaltic trachyandesite of Devils Postpile, the spectacular colonnade of which inspired a national monument.

100-50 ka Mammoth Mountain trachydacite edifice built against caldera's southwest wall. The 5 -km-wide, 1-km-high, glacially scoured edifice consists of 22 extrusive domes and coulees of trachydacite (63-71 percent $\mathrm{SiO}_{2}$ ) rich in feldspars, biotite, hornblende, pyroxenes, and Fe-Ti oxides. Two similar domes extruded just northeast of the edifice (fig. 13). A single plinian pumice fall is the only significant pyroclastic deposit preserved. $\mathrm{CO}_{2}$ flux through the edifice is released from basalt at depth. Edifice products are alkalic, like the many mafic lavas erupted in its periphery (230-8 ka), but unlike the subalkaline rhyolites of the Long Valley magma system (figs. 14, 15).

100-90 ka Youngest basaltic lava flows in the caldera's north and south moats. The two flows erupted through basement rocks at vent cones north and south of Mammoth Mountain. They flowed $23 \mathrm{~km}$ and $18 \mathrm{~km}$ to their respective termini in the north and south moats (fig. 10).

$66 \mathrm{ka}$ Apron of basaltic trachyandesite in west moat. Erupted near the foot of Mammoth Mountain, the mafic lavas (51.2-54.2 percent $\mathrm{SiO}_{2}$ ) flowed $11 \mathrm{~km}$ northeastward to bank against the caldera's north wall. The apron's proximal half is largely concealed by till; its distal half, beyond the Pleistocene glacial limit, is a little-eroded steep-sided coulee.

40-27 ka Chain of trachydacite lavas in the northwest moat. Five discrete, nonglaciated domes and coulees of related but variably contaminated phenocryst-rich magma (60.4-67.3 percent $\mathrm{SiO}_{2}$ ) erupted $\sim 9 \mathrm{~km}$ north of Mammoth Mountain. The vents are aligned along a 2.5-km-long southeasterly trend, and the five yield similar paleomagnetic directions, suggestive of a brief extrusive episode that conflicts with the spread in their ${ }^{40} \mathrm{Ar} /{ }^{39} \mathrm{Ar}$ ages.

$33 \mathrm{ka}$ Scoria cone and lava-flow apron in west moat. A large cone west of Crater Flat issued lava flows (53.3-54.2 percent $\mathrm{SiO}_{2}$ ) that extended $9 \mathrm{~km}$ northeast to the caldera wall at Crestview.

31 ka Basalt of Horseshoe Lake. Phenocryst-rich basaltic lava (49 percent $\mathrm{SiO}_{2}$ ) on the floor of the Lakes Basin erupted from a vent that was later glacially excavated to form the bowl of Horseshoe Lake. Coarse scoria and streaky fountainfed lava are preserved on the east shore of the lake. Glacially 
transported clasts of the basalt are present in nearly all of the many moraines downstream along Mammoth Creek.

29-14 ka Marine Isotope Stage 2, Tioga glaciation in the Sierra Nevada. Separate glaciers from Lakes Basin and Mammoth Mountain deposited as many as 40 nested moraines in and near the Town of Mammoth Lakes. A few more moraines were deposited by contemporaneous ice that flowed northward from Sherwin and Laurel Creeks on the caldera's south wall. Stage 2 moraines are well preserved at the mouths of most Sierran canyons north and south of the caldera.

$16 \mathrm{ka}$ Chain of mafic vents erupted on caldera wall northeast of Deadman Pass. Glacially eroded remnants of phenocryst-rich scoria and agglutinate of basaltic trachyandesite (52.4-53.7 percent $\mathrm{SiO}_{2}$ ) erupted at a northwest-aligned chain of three vents at the head of Deadman Creek. Coerupted lava and monolithologic diamict crop out sparsely through surficial deposits on the caldera floor.

8 ka Basalt of Red Cones. A pair of postglacial scoria cones, agglutinate, and a fountain-fed apron of basaltic lava flows (49.9-51.2 percent $\mathrm{SiO}_{2} ; 7.9-8.3$ percent $\mathrm{MgO} ; 0.6-0.8$ percent $\mathrm{K}_{2} \mathrm{O}$ ), erupted $3-4 \mathrm{~km}$ southwest of the southern toe of Mammoth Mountain.

5-6 ka? North Deadman Dome. This undated lava dome (74.7 percent $\mathrm{SiO}_{2}$ ) at the foot of the northwest topographic wall of Long Valley Caldera, on the north bank of Deadman Creek, is estimated to be of middle Holocene age. The glassy aphyric dome is steep-sided, craggy, nearly circular in plan, $600 \mathrm{~m}$ in diameter, has $130 \mathrm{~m}$ relief, and is forested.

1.3 ka? Wilson Butte. This undated lava dome (76.6 percent $\mathrm{SiO}_{2}$ ) lies $\sim 5 \mathrm{~km}$ north of the caldera wall and $3 \mathrm{~km}$ south of the southernmost dome of the continuous Mono Craters chain. The glassy aphyric dome is steep-sided, craggy, circular in plan, $700 \mathrm{~m}$ in diameter, has $150 \mathrm{~m}$ relief, and is barren of vegetation. Although it is part of the north-south Inyo chain alignment controlled by the range-front fault, its magma composition is that of the arcuate Mono Craters chain.

1350 C.E. Inyo chain eruptions. Four subplinian pumice falls, three pancake coulees, and several phreatic craters erupted from a dike-fed vent chain that extends north-south across the caldera's northwest wall and into its west moat. Complexly mixed and mingled combinations of magma (70-74 percent $\mathrm{SiO}_{2}$ ) are thought to have been confluent from Mono Craters, Long Valley, and a silicic-alkalic reservoir. All are inferred to have ascended through a common dike that paralleled or utilized the range-front fault. The total volume of magma erupted was $\sim 0.6 \mathrm{~km}^{3}$. The eruption was dated by tree-ring investigations to late summer of 1350 C.E. (Millar and others, 2006).

1980 C.E. Four M6 earthquakes in the Sierran block. Four damaging shocks in May 1980 in the basement just south of the caldera heralded onset of decades of recurrent seismicity along the caldera's south moat and within a contiguous domain extending $20 \mathrm{~km}$ south in the Sierra Nevada. The unrest stimulated multifaceted geophysical monitoring that continues today (Hill and others, 2002; Hill, 2006). Tectonic disturbance of the vigorous hydrothermal system may account for most of the south moat unrest, but (controversially) some evoke magmatic intrusion beneath the caldera.

\section{C.E. Onset of tree-killing $\mathrm{CO}_{2}$ flux at Mammoth}

Mountain. Probably triggered by 1989 seismicity beneath the edifice, enhanced concentration of $\mathrm{CO}_{2}$ in soil gas started killing trees at 10 sites that define a half-ring around the western toe of the trachydacite edifice. $\mathrm{CO}_{2}$ flux has diminished but still fluctuates, and its impact on trees continues in 2017.

\section{Excursion Logistics and 38 Stops}

Distances between stops are given in miles, in accord with most vehicle odometers in use in California. [1 mile = $1.61 \mathrm{~km}]$. Stops are numbered in a potential sequence for the 2017 IAVCEI excursion, but descriptions and directions for most stops are written freestanding, allowing each to be visited independently in any order selected. Nearly all roads between stops are graded gravel or paved. For Stops 20 and 31, we recommend four-wheel drive. For Stops 19 and 23, a vehicle with high clearance would be useful, not essential. GPS locations to $100 \mathrm{~m}$ (easting/northing) are given. Note that we use the UTM grid, 1927 North American datum, zone 11, which is the grid printed on USGS topographic maps of the area. Figure 16 shows locations of Stops 0-38.

Stop 0. Caldera orientation from Highway 395 Vista Point (03455/41600). When driving from Toms Place toward Mammoth Lakes on Highway 395, a convenient pulloff is 0.6 mile west of the South Landing overpass. Alternatively, from the Convict Lake road at divided Highway 395, the South Landing overpass is $6.5 \mathrm{~km}$ southeast (toward Toms Place and Bishop); cross over at the overpass and return 0.6 miles to the Vista Point pulloff on the right (Crowley Lake) side of the northwest-bound lanes. The sweeping caldera view here provides an easy opportunity for an introductory orientation. It could be done during Day 0 arrival or at the beginning of Day 1 .

Features visible include: Lowland eastern half of Long Valley Caldera; precaldera Glass Mountain and the caldera's east wall; evidence of the middle Pleistocene caldera lake; raggedly eroded Bishop Tuff untouched by caldera-lake wave action contrasting with smooth lake-planed equivalent; modern Lake Crowley reservoir and its outlet into Owens River Gorge; Sierra Nevada range front, McGee Mountain, and the Hilton Creek Fault; moraines from McGee Creek and Hilton Creek.

McGee Mountain, 5-6 km west of here and 1,200 m higher, is capped by a low-relief Pliocene surface, upon which early Pleistocene glacial moraines were deposited. The McGee Till is by far the oldest glacial deposit yet recognized in the American West. Its dominantly granodiorite boulders were 

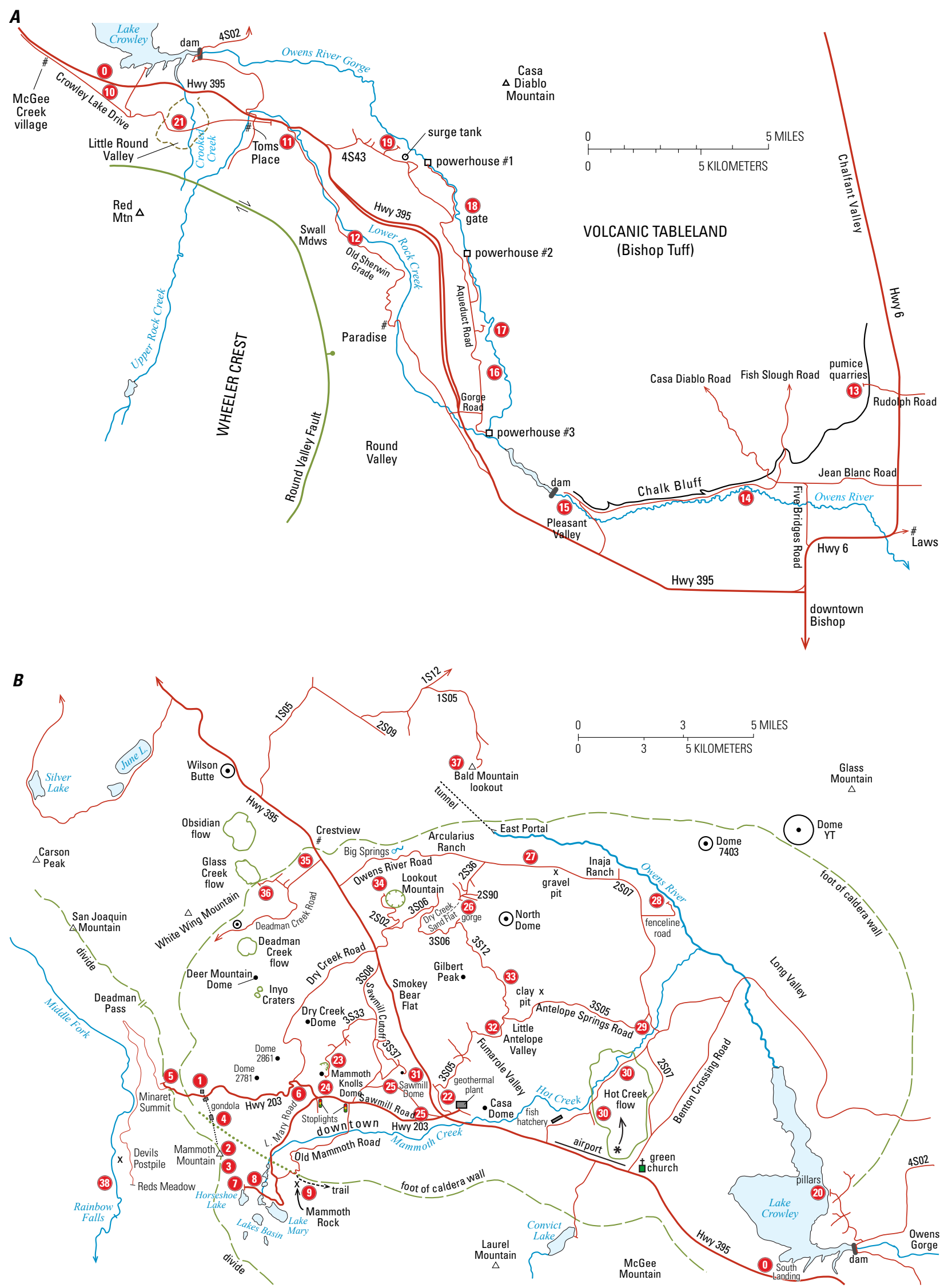

Figure 16. Outline maps with all field-trip stops numbered. $A$, Owens River Gorge area, from Toms Place to Bishop. B, Caldera and vicinity. Roads shown in red. 
carried northward from upper McGee Creek and dropped on the Pliocene surface before the northeast-trending lower canyon of McGee Creek was incised. The base of the McGee Till slopes gently northward from an elevation of 3,260 m to $2,900 \mathrm{~m}$ at the rim of the plateau, and it rests on two different basaltic lava flows for which we have ${ }^{40} \mathrm{Ar} /{ }^{39} \mathrm{Ar}$ ages of 2.8 and 2.6 Ma. Where the MIS 6 and MIS 2 moraines (Tahoe and Tioga glaciations in the Sierra Nevada) emerge from the mouth of present-day McGee Creek canyon, their bases are at $\sim 2,300 \mathrm{~m}$. At least $600 \mathrm{~m}$ of the rangefront relief developed since deposition of the McGee Till, principally by normal slip on the east-dipping Hilton Creek Fault. At Rock Creek, $7 \mathrm{~km}$ southeast of the Vista Point, moraine deposits of Sherwin Till (MIS 22; 900-866 ka) emerge from the canyon mouth at a basal elevation of 2,400 $\mathrm{m}$. This suggests that most of the post-McGee Till rangefront relief was produced well before $900 \mathrm{ka}$, implying an age for the undated till closer to $2 \mathrm{Ma}$ than to $1 \mathrm{Ma}$.

\section{Day 1. Mammoth}

\section{Stop 1. North foot of Mammoth Mountain}

(03202/41689). Adventure Center and bronze mammoth are adjacent to the gondola terminal and across the road from the Main Lodge of the Mammoth Mountain Ski Area.

Each knoll and ledge on the mountain is one of 22 separate domes or coulees of phenocryst-rich trachydacite that built the edifice between $100 \mathrm{ka}$ and $50 \mathrm{ka}$. Two more contemporaneous trachydacite domes lie just off the edifice to its northeast. The lavas range continuously in $\mathrm{SiO}_{2}$ from 63 to 71

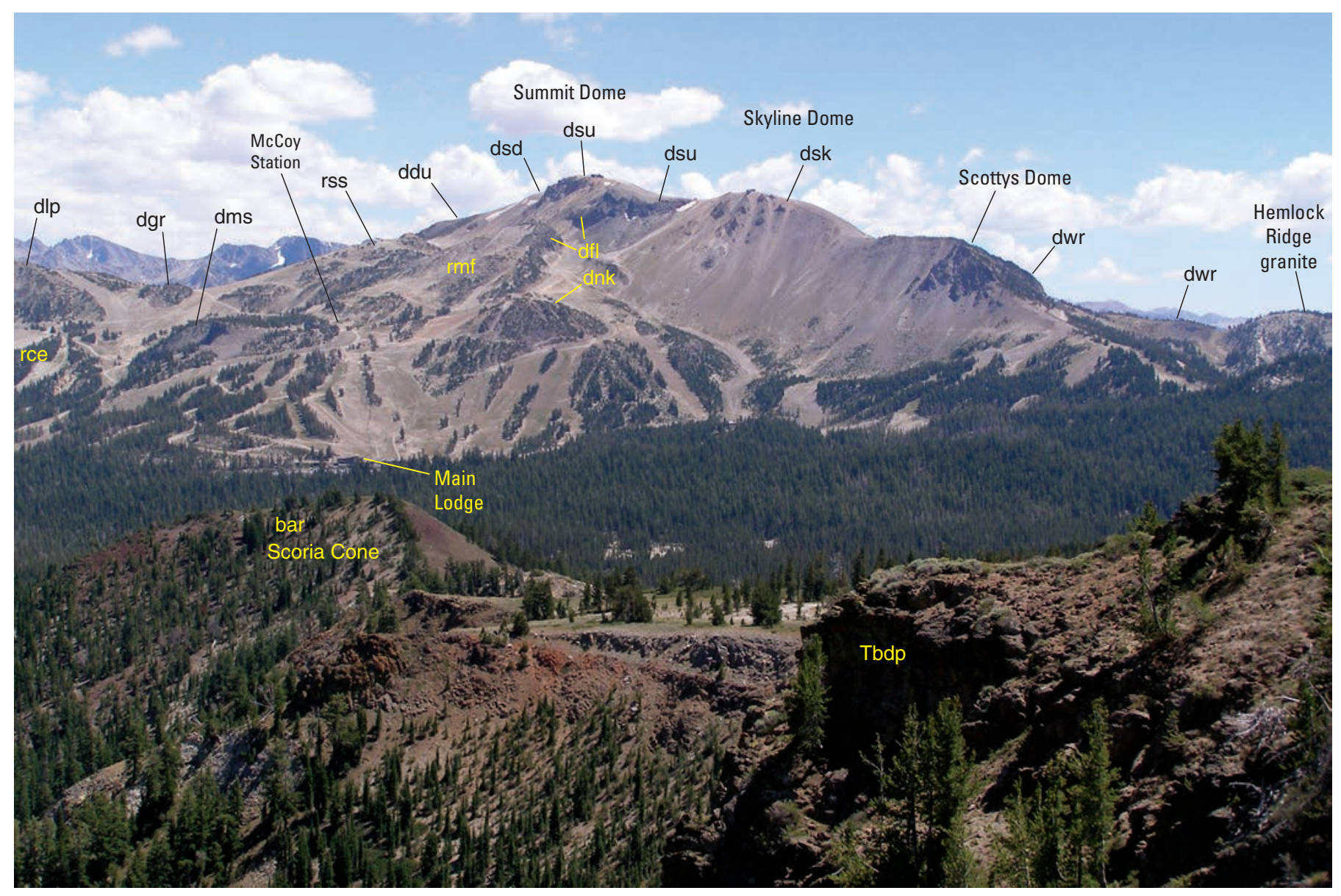

Figure 17. North side of Mammoth Mountain, viewed from caldera rim $5.5 \mathrm{~km}$ north-northwest of summit. Northwest-trending dome alignment supports crest, and several more silicic domes and flows are identified by unit label on northeast slope. All units are described in detail by Hildreth and Fierstein (2016a); all those visible here erupted in interval 90-50 ka. In left foreground, red scoria cone, source of extensive lava flows of unit bar (see Stop 27), erupted $\sim 90 \mathrm{ka}$. Cliffs in near foreground are precaldera stack of Pliocene basalts (unit Tbdp). Summit of Mammoth Mountain is $650 \mathrm{~m}$ higher than ski area's Main Lodge (assembly site for Stop 1), which can be seen at foot of edifice where ski runs meet forest. Scottys Dome marks vent for an extensive set of lava flows. Skyline Dome is widely acid-altered, as is notch below Summit Dome. From left to right, Mammoth eruptive units shown are rce, alkaline rhyodacite of Canyon Express; dlp, trachydacite of Lincoln Peak; dgr, trachydacite of Gold Rush Express; dms, trachydacite of McCoy Station; rss, alkali rhyodacite of Solitude ski run; ddu, trachydacite of upper Dragons Back; rmf, alkali rhyodacite of Mammoth Mountain fumarole; dsd, trachydacite of South Summit Dome; dfl, trachydacite of Face Lift; dnk, trachydacite of North Knob; dsu, trachydacite of Mammoth Mountain summit; dsk, trachydacite of Skyline Dome; and dwr, trachydacite of White Bark Ridge. 
percent, and all are mildly alkaline, flow-foliated, and widely glassy. Most contain 13-35 percent phenocrysts, but the five most silicic have only 5-15 percent. All contain Fe-Ti oxides, biotite, sodic sanidine, and plagioclase, the last always the most abundant. Hornblende is present in 18 of the 24 effusive units and sparse pyroxenes in 20 (table 1 of Hildreth and others, 2014). The entire edifice was ice-covered during MIS 2 (called the Tioga glaciation in the Sierra Nevada), and its ice-transported debris now forms moraines in downtown Mammoth Lakes. Pyroclastic deposits were stripped by glaciation (or concealed by colluvium) except for one plinian pumice fall $(\sim 80 \mathrm{ka})$, which is preserved at several off-edifice sites (Stop 6). The summit is $\sim 650 \mathrm{~m}$ above the Main Lodge at an elevation of 3,362 $\mathrm{m}$ (fig. 17). The edifice is outside the structural caldera and was constructed against a steeply glaciated wall of Cretaceous granite. Mammoth Mountain has not erupted for 50,000 years.

Stop 2. Summit of Mammoth Mountain (03207/41665). The upper terminal of the gondola contains an interpretive center and a café. Outdoors, the summit is commonly cool and windy, and the 3,362-m altitude may affect some visitors with light-headedness or headache.

To the west lies the glaciated canyon of the Middle Fork of the San Joaquin River and beyond it the serrate Ritter Range, a Mesozoic metavolcanic terrane intruded by Cretaceous granitoid plutons of the Sierra Nevada batholith. To the north lies the west wall of Long Valley Caldera, consisting of metamorphic rocks overlain by Pliocene basaltic lavas, which are in turn capped by late Pliocene trachydacite domes and pyroclastic deposits. The east-facing range-front fault system, which is younger than $2.6 \mathrm{Ma}$, is here embayed by the $0.767-\mathrm{Ma}$ caldera wall but continues far to the north. Several mafic cinder cones and rhyolite domes on the forested floor and walls of the caldera's west moat range in age from $\sim 125$ ka to late Holocene. To the east lies the town of Mammoth Lakes, a sagebrush-covered belt of $\sim 40$ nested moraine ridges of MIS 2, several mafic lava flows (180-92 ka) along the seismically active south moat, and a forested highland of early postcaldera rhyolite $(750-640 \mathrm{ka})$ that has been lifted $\sim 400 \mathrm{~m}$ as the caldera's resurgent dome. The distant eastern lowland is Long Valley proper, site of a middle Pleistocene caldera lake, and beyond it rises the caldera's east wall.

For the view to the south, walk $500 \mathrm{~m}$ southward to the brink of the Lakes Basin for Stop 3.

\section{Stop 3. Lakes Basin rim overlook from South Summit Dome (03209/41660).}

Trachydacite of the summit dome at the upper gondola terminal yielded a ${ }^{40} \mathrm{Ar} /{ }^{39} \mathrm{Ar}$ age of $61 \pm 2 \mathrm{ka}$, whereas the South Summit Dome now underfoot is the largest and one of the oldest $(87 \pm 6 \mathrm{ka})$ extrusions on the edifice. Although widely acid altered on top, the dome is generally fresher on its lower slopes. The cirque basin that holds the lakes (fig. 18) was excavated by ice that flowed away from the granite wall of Mammoth Crest on the west and from the canyon of Cold Water Creek on the south, which is largely walled by Mesozoic metavolcanic rocks. This lithologic contrast is maintained in discrete moraines that extend downstream into the town of Mammoth Lakes. Of the several lakes in the basin below, the largest is Lake Mary, which lies at an elevation of $2,720 \mathrm{~m}, \sim 600 \mathrm{~m}$ below our viewpoint. In the near corner of the basin is Horseshoe Lake and an adjacent $\mathrm{CO}_{2}$-killed forest, which will be visited at Stop 7.

In the periphery of the Mammoth Mountain edifice (and some from beneath it), at least 25 mafic and intermediate eruptions took place between $230 \mathrm{ka}$ and $8 \mathrm{ka}$. A few of the vents can be seen from here. In the woods 4-5 km southwest are the Red Cones, a pair of basaltic scoria cones (50-51 percent $\mathrm{SiO}_{2}$ ) only $\sim 8,000$ years old, the youngest nonrhyolitic eruptive unit in the region. Beyond them rise two forested scoria cones (fig. 19), each $\sim 150 \mathrm{~m}$ high and both trachyandesitic (57-59 percent $\mathrm{SiO}_{2}$ ). Cone 2962, on the left, gave a ${ }^{40} \mathrm{Ar} /{ }^{39} \mathrm{Ar}$ age of $118 \pm 10 \mathrm{ka}$, and Pumice Butte on the right gave $142 \pm 5 \mathrm{ka}$. Neither is badly eroded because they erupted on an interfluvial granite plateau that stood above the nearby MIS 2 glaciers.

Closer at hand, only $3.5 \mathrm{~km}$ south of our rim viewpoint, glaciated remnants of a red basaltic spatter/scoria cone (4950 percent $\mathrm{SiO}_{2}$ ) stand atop the granite wall of Mammoth Crest. In common with the ejecta, derivative lava flows are distinctive in containing abundant large plagioclase crystals (1-22 mm). The lavas have been traced $18 \mathrm{~km}$ in wells and outcrops to a terminus at Hot Creek and correlated chemically, petrographically, and paleomagnetically. The cone and distal lava yielded independent ${ }^{40} \mathrm{Ar} /{ }^{39} \mathrm{Ar}$ ages of $92.5 \pm 2.5 \mathrm{ka}$.

Part of the floor of Lakes Basin is an ice-scoured sheet of phenocryst-rich basalt ( 49 percent $\mathrm{SiO}_{2}$ ) that erupted at the site of glacially excavated Horseshoe Lake, as shown by coarse ejecta and agglutinate along the eastern lakeshore. The lava contains 18-24 percent olivine, clinopyroxene, and plagioclase and gave a ${ }^{40} \mathrm{Ar} /{ }^{39} \mathrm{Ar}$ age of $31 \pm 1 \mathrm{ka}$. Its distinctive erratics are present in all of the many moraines sourced from the Lakes Basin, even the most distal along Mammoth Creek, proving that the entire set of $\sim 40$ moraine ridges was deposited during MIS 2.

The overlook also provides a fine view of high-elevation low-relief Pliocene surfaces that have so far survived the erosive encroachment induced by Quaternary range-front faulting and caldera collapse. Atop Red Mountain, the ridge of Mesozoic metavolcanic rocks that forms the steep eastern wall of Lakes Basin above Lake Mary (fig. 20), an extensive rolling plateau is a partly unglaciated remnant of such a precaldera surface. Dark-gray olivine-rich basalt (51.5 percent $\left.\mathrm{SiO}_{2} ; 3.15 \pm 0.1 \mathrm{Ma}\right)$ that fills a shallow channel cut into the north rim of the plateau (fig. 20) is the type locality of the Mammoth Reversed-Polarity Subchron of the geomagnetic polarity timescale. Another basalt flow (50 percent $\mathrm{SiO}_{2}$; $3.20 \pm 0.01 \mathrm{Ma}$ ) is preserved as remnants along the west rim of the plateau. Scattered sparsely on the plateau surface are blocks of andesite, dacite, and low-silica rhyolite and pebbles of high-silica obsidian, none of certain provenance. Atop granitic Mammoth Crest, the southwest wall of Lakes Basin, 


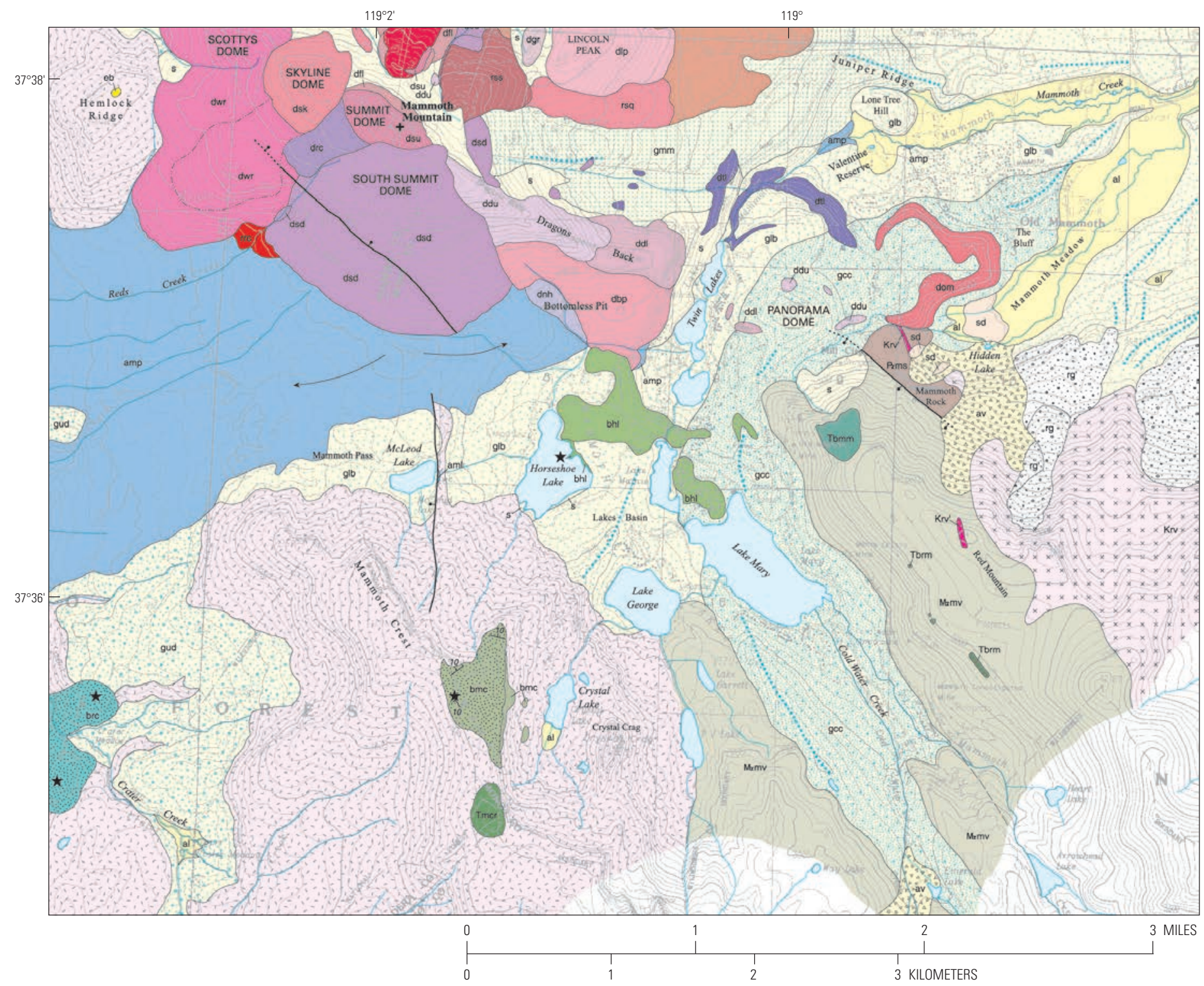

\section{EXPLANATION}

- Normal fault; dotted where concealed .... Moraine crests

$\star$ Volcanic vent

al alluvium

Trachyandesite of McLeod Lake trachydacite of Mammoth Pass basalt of Horseshoe Lake basalt of Mammoth Crest basalt of Red Cones trachydacite of Bottomless Pit trachydacite of Dry Creek trachydacite of lower Dragons Back trachydacite of upper Dragons Back trachydacite of Face Lift trachydacite of Gold Rush Express trachydacite of Lincoln Peak trachydacite north of Horseshoe Lake trachydacite of Old Mammoth trachydacite of upper Reds Creek trachydacite of South Summit Dome trachydacite of Skyline Dome trachydacite of Mammoth Mountain summit trachydacite of Twin Lakes outlet trachydacite of White Bark Ridge explosion breccia till of Cold Water Canyon till derived from Lakes Basin till derived from Mammoth Mountain

Kmo Mono Creek Granite of the John Muir Intrusive Suite Krr
Krv' leucogranitic dikes that issued from Round Valley Peak Granodiorite pluton

Mzmv metavolcanic rocks of Ritter Range pendant

$\mathrm{P}_{z \mathrm{~ms}}$ metasedimentary rocks of Mount Morrison pendant

rce alkali rhyodacite of Canyon Express

r.r. o. rock glacier deposits

rg' - inactive rock glacier deposits

alkali rhyodacite of Reds Creek

alkali rhyodacite of Quicksilver ski run

alkali rhyodacite of Solitude ski run

surficial deposits, undivided

spring deposits

Trachybasalt of Mammoth Mine

Basalt of Red Mountain

Basaltic trachyandesite of Mammoth Crest 
Figure 18. Geologic map of Lakes Basin, a large cirque at south foot of Mammoth Mountain. Crystal-poor andesite of Mammoth Pass (unit amp; $97 \pm 1 \mathrm{ka}$ ) erupted on Sierran drainage divide beneath later site of Mammoth Mountain, flowing $9 \mathrm{~km}$ east and $>7 \mathrm{~km}$ southwest. Basaltic scoria cone (unit bmc; $92 \pm 2 \mathrm{ka}$ ) on top of Cretaceous granite on Mammoth Crest fed phenocryst-rich lava flows that extended $18 \mathrm{~km}$ east to Hot Creek. Horseshoe Lake is glacially scoured vent for phenocryst-rich basalt (unit bhl; $31 \pm 1$ ka) preserved only on the floor of the Lakes Basin. Undated hornblende andesite of McLeod Lake (unit aml) is exposed only as a glaciated lava ledge near the east shore of the lake, but it underlies unit amp in drillholes 1-7 km farther east. Three mafic lavas that rim the Lakes Basin (units Tbmm, Tbrm, and Tmcr) are Pliocene units that predate glacial excavation of the cirque. Basement rocks include Cretaceous granitoid plutons (units Kmo and Krv, light pink) and Mesozoic metavolcanics (unit Mzmv, tan). For full map of Mammoth Mountain, see figure 13. Pale colored surficial units include alluvium (al), rock glaciers (rg), and glacial deposits of different provenances (units gcc, glb, gmm, gud). Rim of South Summit Dome is site of Stop 3. All units described in detail by Hildreth and Fierstein (2016a).

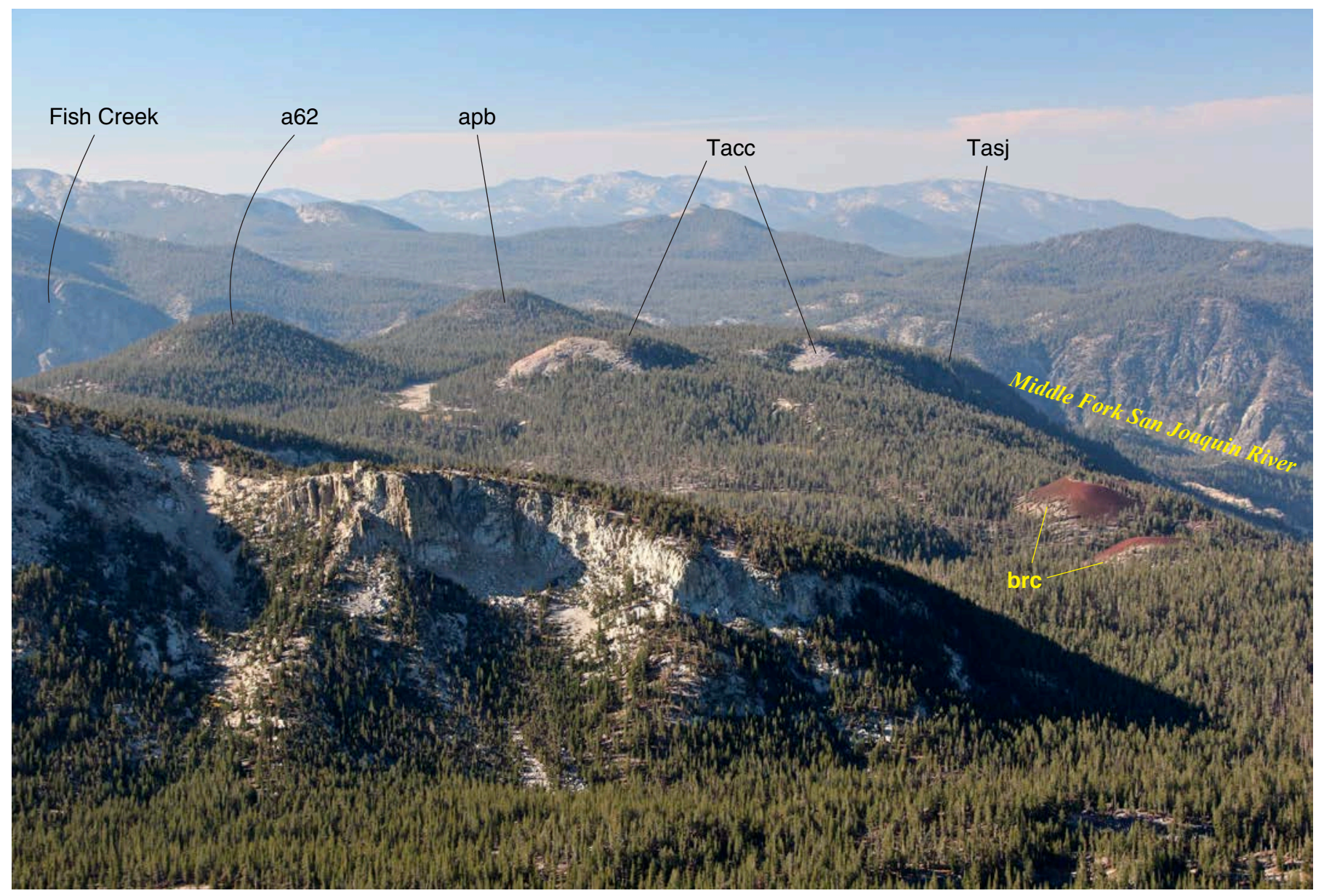

Figure 19. Peripheral vent cluster 5-9 km south of Mammoth Mountain. Pair of small red scoria cones (unit brc, basalt of Red Cones) erupted in early Holocene ( $8 \mathrm{ka}$ ). Pair of large forested scoria cones (units a62 and apb, trachyandesites of Cone 2962 and Pumice Butte) erupted in interval 150-110 ka. Pair of pale gray lava domes (unit Tacc, trachyandesite of Crater Peak) erupted in the Pliocene. Low-relief forested foreground is Mammoth Pass, which is floored by lava-flow apron of trachyandesite of Mammoth Pass (unit amp; 97 ka). Canyon of Fish Creek is hidden behind Pumice Butte (unit apb); its confluence with Middle Fork San Joaquin River is at right. Canyon walls and glacially excavated nose at left center (northwest end of Mammoth Crest) are Mesozoic granite. View south from summit of Mammoth Mountain. 


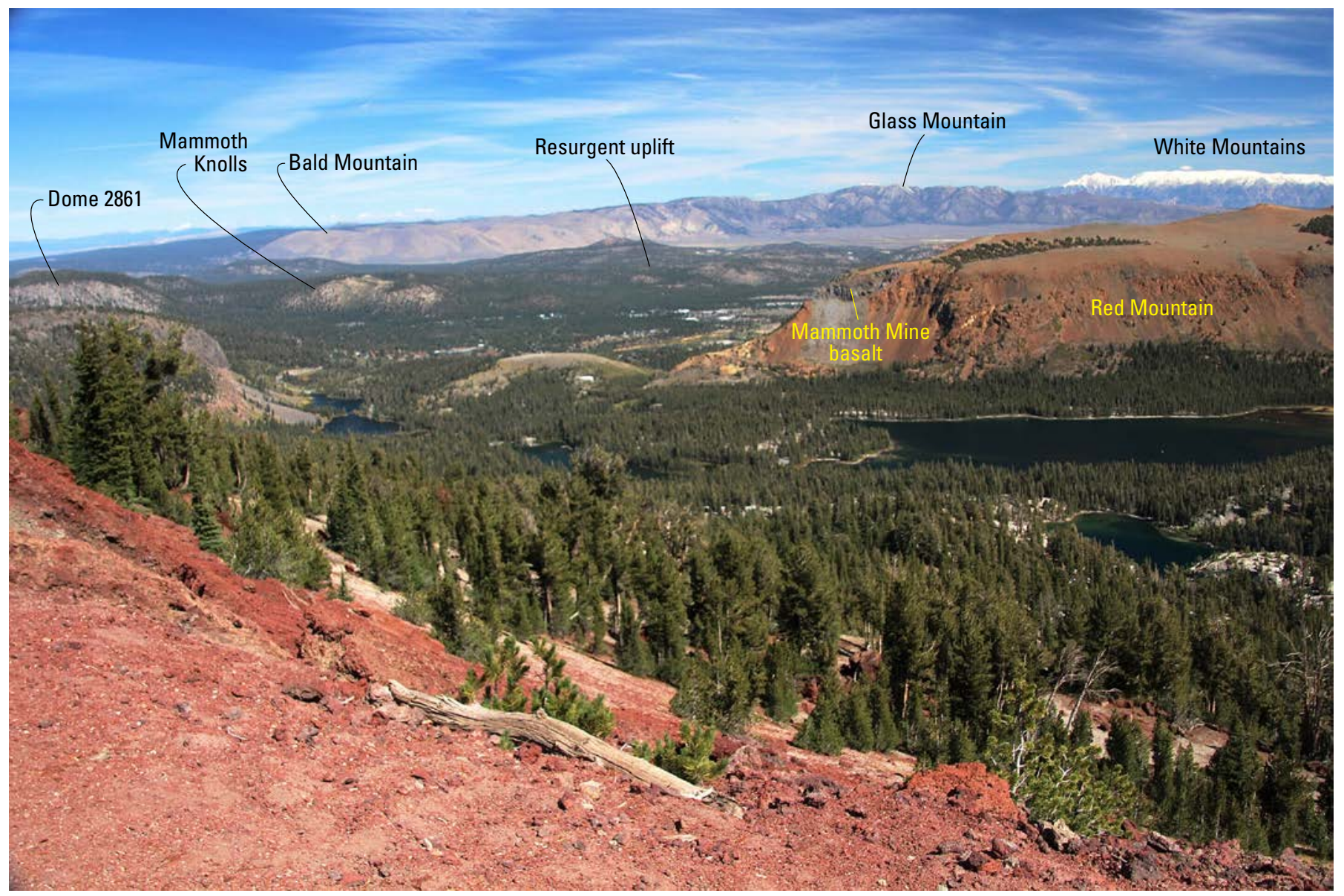

Figure 20. View northeastward from Mammoth Crest across Lakes Basin and Long Valley Caldera. Glass Mountain on the northeast wall of the caldera is $33 \mathrm{~km}$ away. Larger lake at right is Lake Mary; Twin Lakes at left. Red Mountain consists of acid-altered Mesozoic metavolcanic rocks. Much of its flat upland surface was high enough to avoid Pleistocene glaciation. At its left end, the gray basalt of Mammoth Mine, occupying a shallow swale, is the type locality of the 3.1-Ma Mammoth Reversed-Polarity Subchron of the Gauss Normal-Polarity Chron (Doell and others, 1966). Steep Dome 2861 is 87-ka trachydacite. Bilobate Mammoth Knolls dome is 100-ka rhyolite. The camera is on the Mammoth Crest basaltic scoria cone (92 ka).

a smaller relict surface $\left(\sim 1 \mathrm{~km}^{2}\right)$ is capped by another olivinerich lava flow (52-53 percent $\left.\mathrm{SiO}_{2} ; 3.30 \pm 0.01 \mathrm{Ma}\right)$ and strewn with the same varied suite of erratic blocks as on Red Mountain, which is $4 \mathrm{~km}$ northeast across the deep Lakes Basin cirque.

Stop 4. Trachydacite of McCoy Station. From the midway chalet (03209/41679) along the gondola cableway, walk $150 \mathrm{~m}$ northeast through the woods to the cliffy margin of one of Mammoth Mountain's well-exposed coulees (03210/41680).
The glacially scoured plateau-forming flow surface exposes flow-foliated vitrophyre in which dense black layers alternate with partly devitrified lenses and layers, some of them spherulitic or lithophysal. The flow has 68.5-69.6 percent $\mathrm{SiO}_{2}$, contains 10-12 percent feldspars, 2-4 percent biotite, $\sim 1$ percent pyroxene, common Fe-Ti oxides, and sparse hornblende, mafic blebs, and multi-phase crystal clots. Feldspar from this unit gave $\mathrm{a}^{40} \mathrm{Ar} /{ }^{39} \mathrm{Ar}$ age of $68 \pm 1 \mathrm{ka}$; the

Figure 21. Geologic map of Devils Postpile area along Middle Fork of San Joaquin River, which flows from north to south through middle of map. Four late Pleistocene intracanyon lava-flow units ponded on canyon floor and extended downstream: (1) unit mss ( 121 ka) erupted at a scoria cone near upper Soda Springs Campground; (2) unit drf ( 98 ka), a single dacite coulee, probably erupted beneath the later site of Mammoth Mountain; (3) unit amp ( 97 ka), an apron of many andesitic flows, did erupt at the later site of Mammoth Mountain and flowed both west into the Middle Fork and east down Mammoth Creek; (4) basaltic trachyandesite of Devils Postpile (unit mdp; 82 ka) ponded as thick as $110 \mathrm{~m}$ on the canyon floor. A pair of postglacial scoria cones (Red Cones; unit brc; 8 ka), fed a lava-flow apron $2.5 \mathrm{~km}$ long. Multi-unit Mammoth Mountain, at right center, is shown in full on figure 13. The Bishop Tuff, calderaforming ignimbrite unit rbt, which originally filled the canyon to welded thicknesses as great as $250 \mathrm{~m}$, was glacially reduced to a few remnants. Pliocene basaltic units Tbld, Tbtb, and Tmcw are likewise small remnants of formerly extensive lavas. All map units except Red Cones are glacially eroded. Light pink is Cretaceous Mono Creek Granite of the John Muir Intrusive Suite (unit Kmo). Bedrock at Stop 5 carpark near Minaret Summit is Mesozoic metavolcanic assemblage (Mzmv, tan). Map extracted and modified from Hildreth and Fierstein (2016a), which gives full desriptions of all units. 


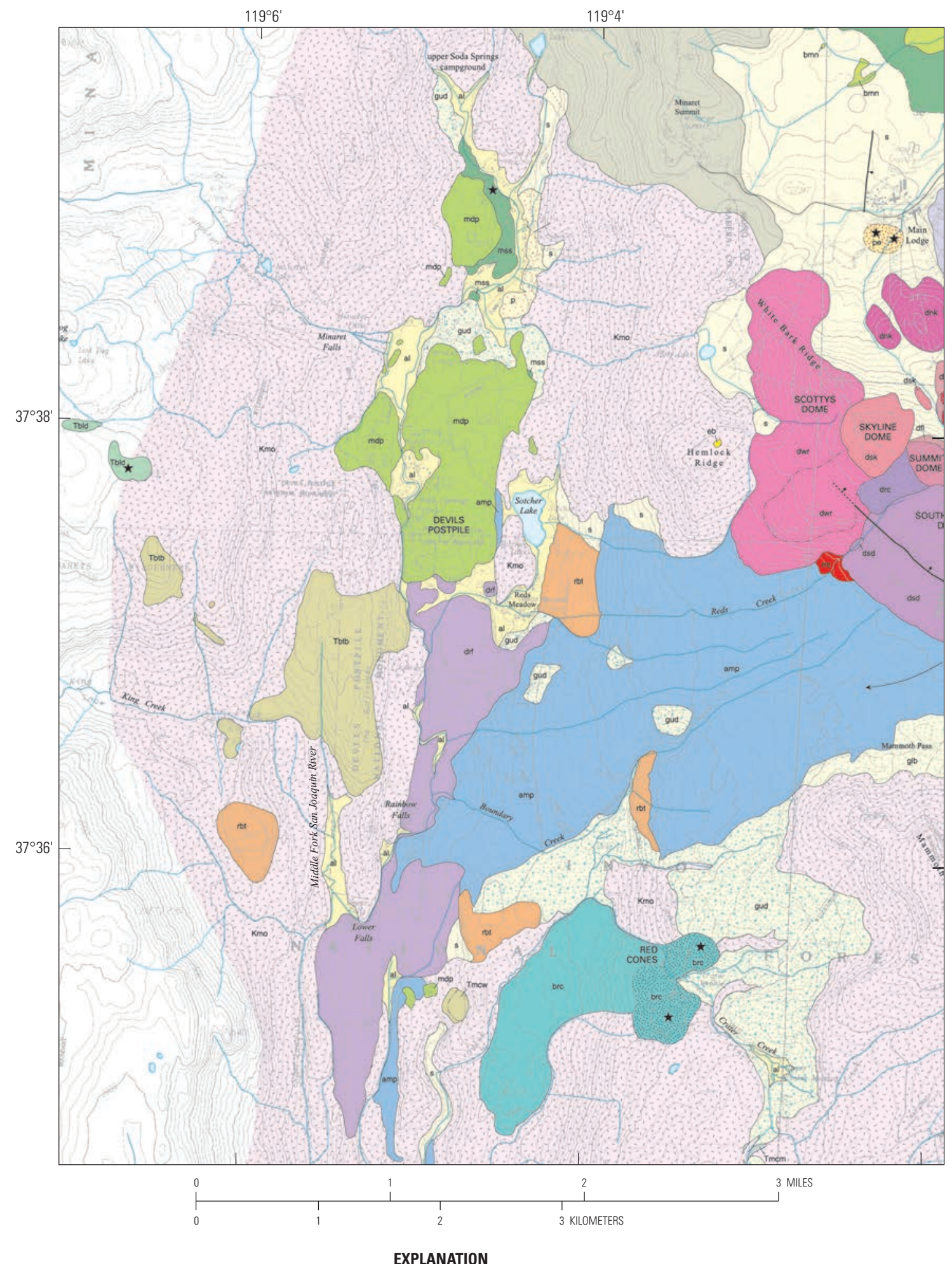

\begin{tabular}{|c|c|}
\hline$\vec{\varphi}$ & $\begin{array}{l}\text { Normal fault; dotted where concealed } \\
\text { Volcanic vent }\end{array}$ \\
\hline al & alluvium \\
\hline amp & trachydacite of Mammoth Pass \\
\hline$\nabla a v^{\prime}$ & rockfall avalanche deposits \\
\hline bar. & trachybasalt of Arcularius Ranch \\
\hline bmn & trachybasalt northeast of Minaret Summit \\
\hline brc: & basalt of Red Cones \\
\hline dfl & trachydacite of Face Lift \\
\hline dnk & trachydacite of North Knob \\
\hline
\end{tabular}

\begin{tabular}{|c|c|}
\hline $\mathrm{drc}$ & trachydacite of upper Reds Creek \\
\hline drf & trachydacite of Rainbow Falls \\
\hline dsd & trachydacite of South Summit Dome \\
\hline dsk & trachydacite of Skyline Dome \\
\hline dsu & trachydacite of Mammoth Mountain summit \\
\hline dwr & trachydacite of White Bark Ridge \\
\hline $\mathrm{eb}$ & explosion breccia \\
\hline glb & till derived from Lakes Basin \\
\hline -gụd & undivided glacial deposits \\
\hline $\mathrm{Kmo}$ & $\begin{array}{l}\text { Mono Creek Granite of the John Muir } \\
\text { Intrusive Suite }\end{array}$ \\
\hline mdp & basaltic trachyandesite of Devils Pos \\
\hline
\end{tabular}

mss Basaltic trachyandesite of upper Soda Springs $\mathrm{Mzmv}$ metavolcanic rocks of Ritter Range pendant p. pumice deposits pe phreatic ejecta

Pzms metasedimentary rocks of Mount Morrison pendant

rbt Bishop Tuff alkali rhyodacite of Reds Creek surficial deposits, undivided Tbld basalt south of Lost Dog Lake Tbtb basalt of The Buttresses

Tmcw basaltic trachyandesite west of Crater Creek 
underlying coulee that extends to the Main Lodge gave $67 \pm 1 \mathrm{ka}$, and two overlying flows gave $61 \pm 3 \mathrm{ka}$ and $61 \pm 1.5 \mathrm{ka}$ (Mahood and others, 2010; Hildreth and others, 2014).

From the bronze mammoth at the lower gondola terminal, drive 1.2 miles west on Highway 203, uphill to a kiosk on the divide and turn right onto a paved side road that ends in $\sim 500$ $m$ at a carpark on the rim of the canyon of the Middle Fork of the San Joaquin River.

Stop 5. Minaret Vista (03181/41693). The schistose metavolcanic rocks underfoot at Minaret Summit belong to a steeply southwest-dipping homoclinal section (Huber and Rinehart, 1965; Bateman, 1992) that overlies Paleozoic metasedimentary rocks and youngs westward from Triassic through Jurassic stratified volcanogenic rocks to a mid-Cretaceous ( $\sim 100 \mathrm{Ma})$ caldera-filling ignimbrite (Fiske and Tobisch, 1994) that forms the serrate Ritter Range 10-13 km to our west. Just below the vista point, the metavolcanic section is intruded by the Mono Creek Granite (one of four enormous Late Cretaceous porphyritic plutons of the Sierra Nevada), which forms Mammoth Crest, walls much of the Middle Fork downstream from here, and extends more than $50 \mathrm{~km}$ southeast (fig. 21).

About $3 \mathrm{~km}$ to our right, a 450-m-thick stack of basaltic lava flows filled and permanently blocked a paleotributary of the Middle Fork. Cut deeply through metamorphic rocks of the canyon's east wall, the kilometer-wide channel had drained a large region later downfaulted to become Mono Basin. ${ }^{40} \mathrm{Ar} /{ }^{39} \mathrm{Ar}$ ages for the base and top of the basalt stack are 3.70 and 3.28 Ma. The basalts erupted before initiation of Sierran range-front faulting east of the modern divide but after the Middle Fork canyon had here been cut to almost its presentday depth. Neogene incision of the Middle Fork canyon is confirmed $\sim 7 \mathrm{~km}$ downstream where the basalt of The Buttresses $(3.75 \mathrm{Ma})$ rests on granite at the modern riverbank (fig. 21). The basaltic trachyandesite of Devils Postpile ( $82 \mathrm{ka}$ ) and glaciated remnants of three other late Pleistocene lava flows (97-121 ka; Hildreth and others, 2014) also rest on granite along the canyon floor just downstream (fig. 21).

Following this stop, consider going down canyon to Stop 38, Devils Postpile and Rainbow Falls, which would require half a day.

Return eastward on Highway 203 and continue downhill $\sim 3$ miles beyond the gondola terminal and $\sim 0.6$ miles beyond a left turnoff for the "Earthquake Fault." Park on the right shoulder of a tight left-bending hairpin curve, and appoint traffic monitors before exiting the vehicles.

Stop 6. Pumice fall in Highway 203 roadcut (03241/41691).

The roadcut exposes $>5 \mathrm{~m}$ of the only surviving pumicefall deposit known to have erupted at Mammoth Mountain. As logged in figure 22, the coarser upper $4 \mathrm{~m}$ is separated from $1.6 \mathrm{~m}$ of stratified lapilli falls by a weak paleosol. The deposit overlies one of the trachydacitic off-edifice lava domes ( $99 \pm 7 \mathrm{ka}$ ). Maximum pumice diameter is $\sim 25 \mathrm{~cm}$, its $\mathrm{SiO}_{2}$ content is $70-71$ percent, it is chemically identical to a lava dome high on Mammoth Mountain that gave a ${ }^{40} \mathrm{Ar}{ }^{139} \mathrm{Ar}$ age of
$80 \pm 1 \mathrm{ka}$, and its own feldspar yielded an age of $80 \pm 8 \mathrm{ka}$. The pumice contains 4-6 percent plagioclase and sodic sanidine, $\sim 1$ percent biotite, and tiny Fe-Ti oxides. Lithic fragments are 94 percent Mammoth Mountain lavas, 4 percent mafic lavas, and 2 percent metavolcanic basement rocks. Partial sections of the deposit are preserved elsewhere along Highway 203 and in downtown Mammoth Lakes, and a section $91 \mathrm{~cm}$ thick is exposed at a quarry $17 \mathrm{~km}$ east of here (fig. 22).

From Stop 6, continue down Highway 203 to the stoplight at The Village and turn right onto Lake Mary Road. Drive 5 miles to Horseshoe Lake carpark at road's end, ignoring several turnoffs en route.

Stop 7. Horseshoe Lake (03216/41646). The 800-m-long basin holding the lake is the glacially excavated vent site of the distinctive basalt of Horseshoe Lake (49 percent $\mathrm{SiO}_{2}, 10$ percent $\mathrm{MgO}, 12-15$ percent plagioclase, 5-7 percent clinopyroxene, 1-2 percent olivine). Proximal scoria fall along the east side of the lake includes bombs as big as $50-80 \mathrm{~cm}$ and is locally armored by agglutinate and streaky block-jointed lava. The volcanic outcrops and the sandy lake floor are strewn with granitic erratics. The lava gave $\mathrm{a}^{40} \mathrm{Ar} /{ }^{39} \mathrm{Ar}$ age of $31 \pm 1 \mathrm{ka}$. Because clasts of the basalt are present in all late Pleistocene moraines derived from Lakes Basin, their presence shows that the entire set of nested moraines along Mammoth Creek were emplaced during MIS 2.

Tracts of dead trees just north of the lake are among 10 such areas around the western base of the Mammoth Mountain edifice. First noticed in 1990, the year after an 11-month-long seismic swarm beneath the mountain, the tree kills were soon recognized to be caused by concentrations of $\mathrm{CO}_{2}$ in the soil gas in the range 20-95 percent (Farrar and others, 1995). Tree-kill sites are absent around the eastern half of the edifice. Their distribution coincides with an arcuate scallop in the basement-rock cirque wall against which Mammoth Mountain was built. The cross-section in figure 23 depicts how permeable rubble along the inward-sloping contact could distribute centrally ascending $\mathrm{CO}_{2}$ to sites along the arcuate surface trace of that contact (Hildreth and others, 2014). A fumarole high on the edifice has long been monitored for its flux of isotopically magmatic $\mathrm{CO}_{2}$ and $\mathrm{He}$ (Sorey and others, 1998). It is inferred that magmatic $\mathrm{CO}_{2}$ degasses from basaltic magma lodged in the middle crust, as suggested by persistent long-period earthquakes at depths of $10-18 \mathrm{~km}$.

From Horseshoe Lake, drive 0.5 mile east, park along the road, and find an unobstructed view toward the glacially incised outlet of the Lakes Basin. The view is probably best from $250 \mathrm{~m}$ west of the Twin Falls outlet of Lake Mamie.

Stop 8. Twin Falls overlook (03244/41644). The icescoured rimrock underfoot is the 31-ka basalt of Horseshoe Lake, accessible on both sides of the road. Across the canyon (fig. 24) to the left are stacked three coulees of Mammoth Mountain trachydacite (each $\sim 67$ percent $\mathrm{SiO}_{2}$ ), which make up the skyline arête called Dragons Back and the wall above Twin Lakes. The middle flow that drapes the reddish lower 


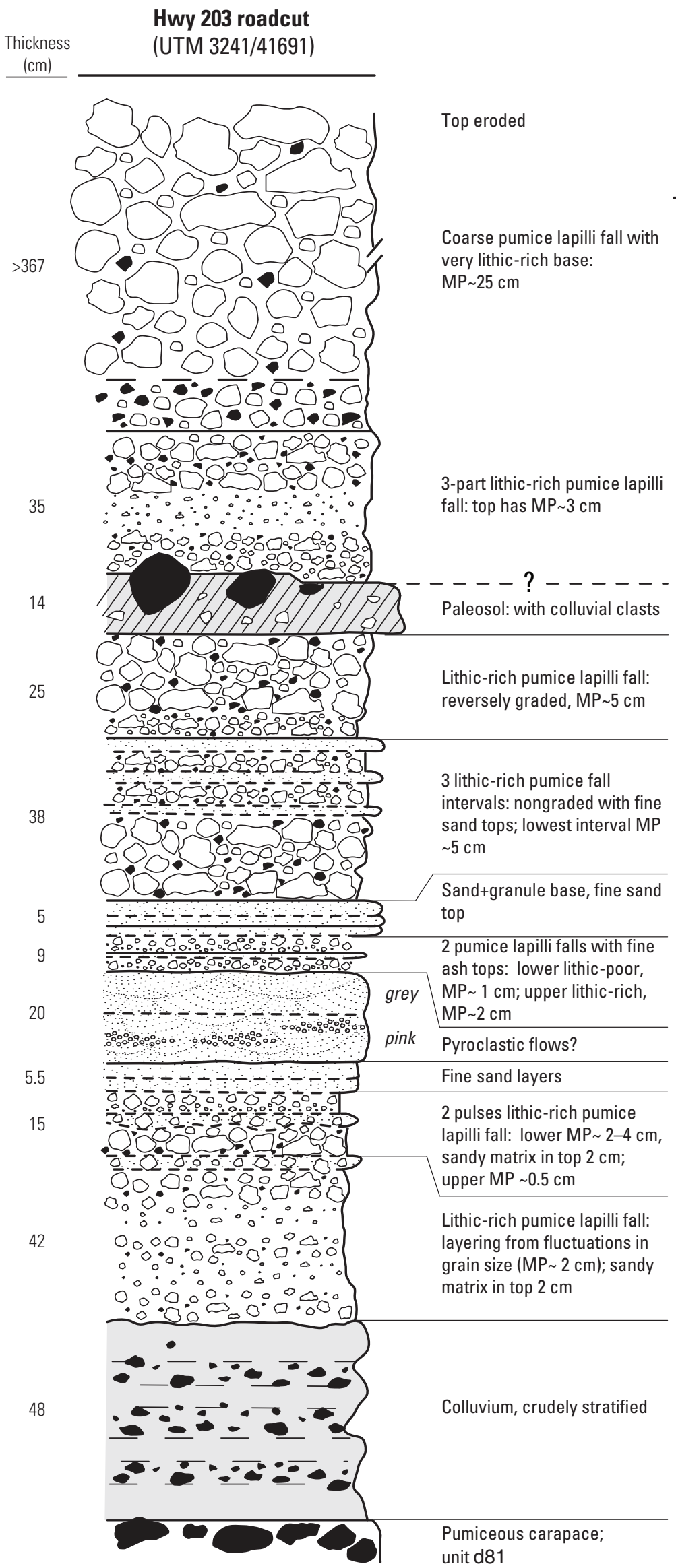

\section{Gravel pit south of Cashbaugh Ranch (UTM 34038/417186)}

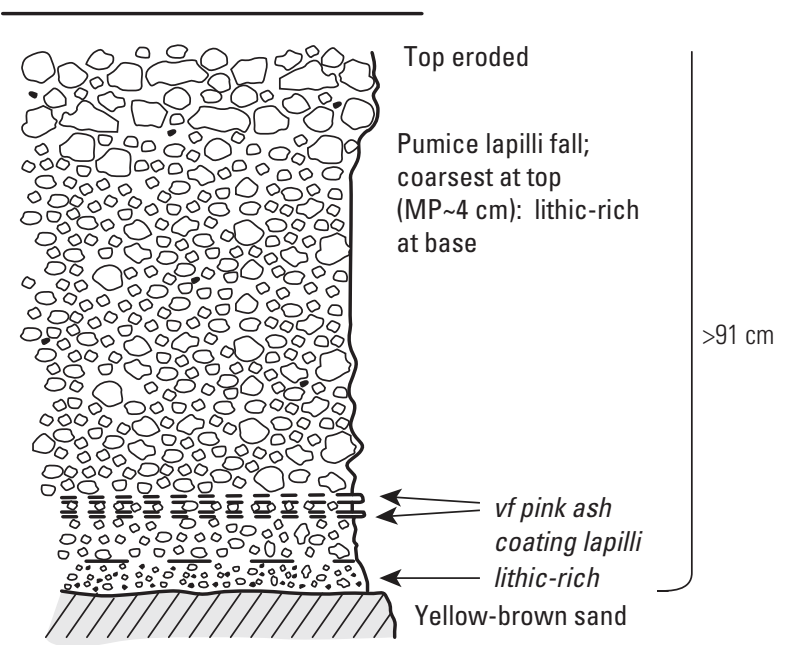

Figure 22. Stratigraphic logs of pumice-fall deposit in Highway 203 roadcut near foot of Mammoth Mountain and at quarry near Cashbaugh Ranch, $17 \mathrm{~km}$ east. Principal fall unit thins eastward from $>4 \mathrm{~m}$ to $\sim 1 \mathrm{~m}$. Large pumice clasts from Cashbaugh site and from $15-\mathrm{cm}$, $25-\mathrm{cm}, 35-\mathrm{cm}$, and thick topmost fall layers at Highway 203 site are all compositionally similar: 70.2-70.7 percent $\mathrm{SiO}_{2} ; 0.20-0.28$ percent $\mathrm{MgO}$; 99-114 parts per million (ppm) Rb; and 372-430 ppm Zr. Lithic fragments throughout fall deposits are nearly all Mammoth Mountain lavas. MP, maximum pumice size-average diameter of five largest clasts found in layer. 
SOUTHWEST

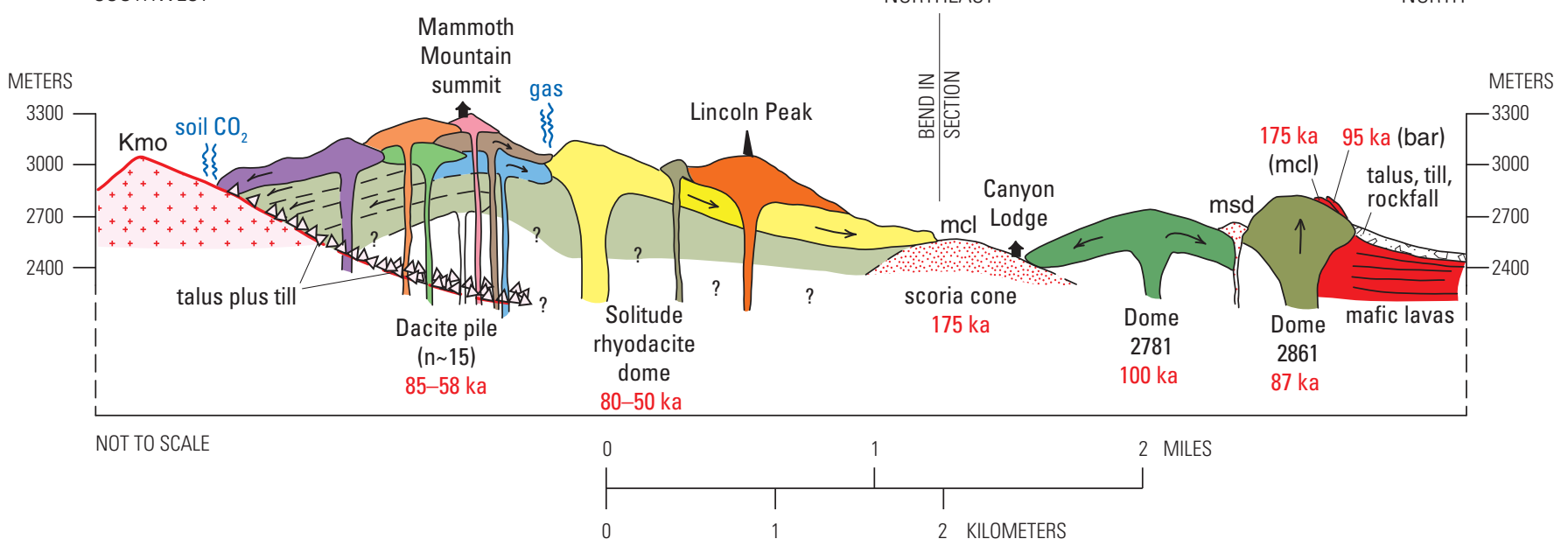

Figure 23. Schematic cross section across summit of Mammoth Mountain, simplifying surface units and hypothesizing a permeable layer of buried rubble that draped the granitic caldera wall against which the edifice was constructed. Some fraction of the $\mathrm{CO}_{2}$ ascending from a deep basalt-fed reservoir toward near-summit fumaroles is diverted laterally toward the half-ring of tree-kill areas, which are limited to the basement half of the edifice, as discussed further in Hildreth and Fierstein (2016a). Section bends northward at Canyon Lodge scoria cone to transect the two off-edifice domes of Mammoth Mountain lithology shown in figure 13. No vertical exaggeration. Unit symbols shown, from left to right, are Kmo, Mono Creek Granite of the John Muir Intrusive Suite; mcl, basaltic trachyandesite of Canyon Lodge; msd, basaltic trachyandesite of scoria southeast of Dry Creek; bar, trachybasalt of Arcularius Ranch.

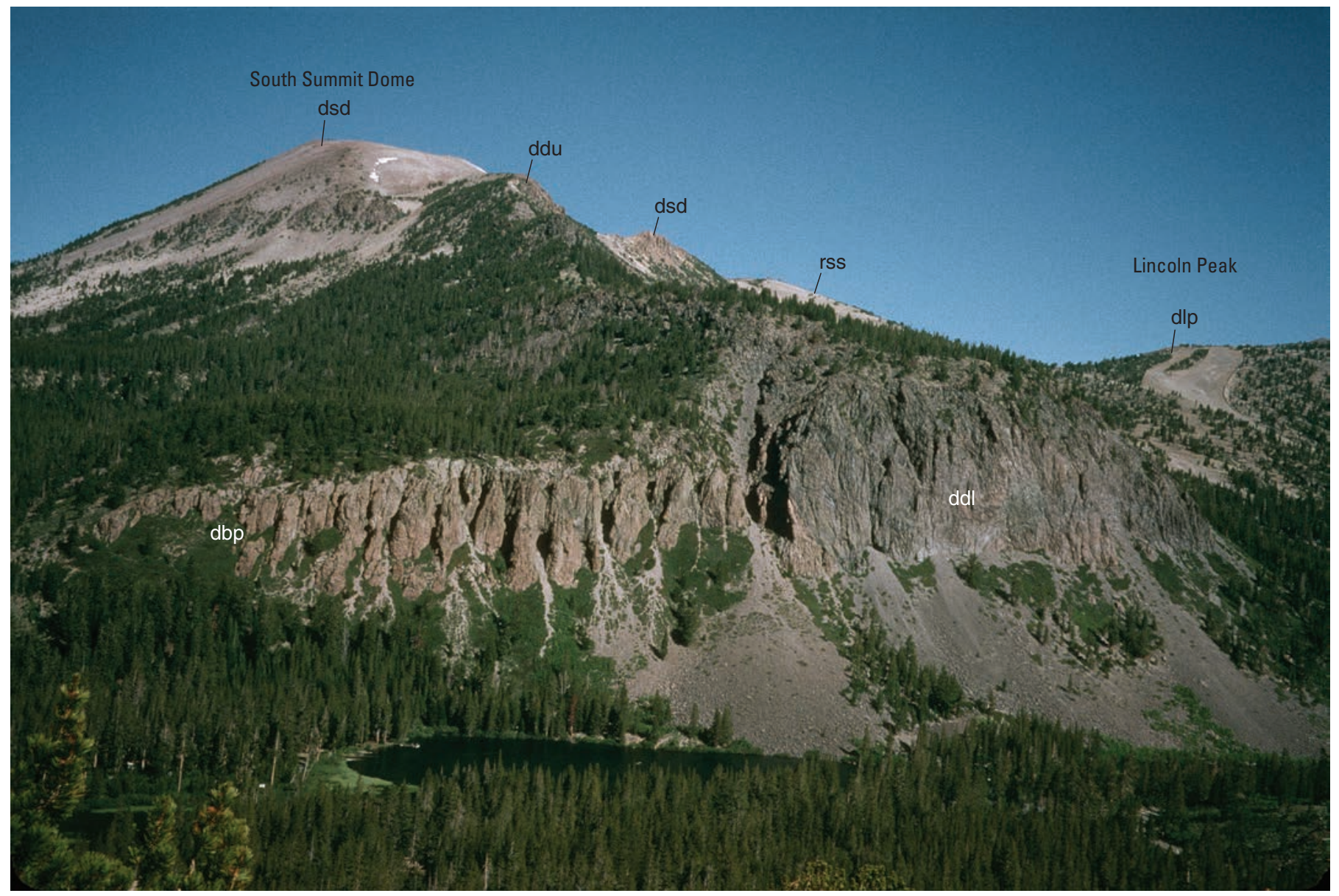

Figure 24. Southeast side of Mammoth Mountain above glaciated trough floored by Twin Lakes. Pervasively oxidized Bottomless Pit flow (unit dbp) is overrun by lower Dragons Back flow (unit ddl), which is here as thick as $180 \mathrm{~m}$. Forested arete near timberline is upper Dragons Back flow (unit ddu), youngest of the three compositinally similar coulees. Units rss and dlp are also among the youngest domes on the edifice (Hildreth and Fierstein, 2016a). On high skyline, pale-colored scree-mantled South Summit Dome (unit dsd), one of the largest and oldest units on the edifice (see Stop 3), is widely altered hydrothermally. 
one gave $\mathrm{a}^{40} \mathrm{Ar} /{ }^{39} \mathrm{Ar}$ age of $58 \pm 2 \mathrm{ka}$ (Mahood and others, 2010). Each of the three flows is as thick as 160-180 m, and all contain 12-15 percent feldspar, 3-5 percent hornblende, and 1-2 percent biotite as well as Fe-Ti oxides and traces of pyroxene. To the right of the Twin Lakes trough, the broad swell called Panorama Dome is trachydacite heavily mantled by metavolcanic till from Cold Water Creek, whereas till transported from the Lakes Basin cirque headwall down the trough and on toward downtown Mammoth Lakes is dominantly granitic (with subordinate but ubiquitous basalt of Horseshoe Lake and trachydacite of Mammoth Mountain). To the east, the 300-m-high wall that confines the Lakes Basin is Red Mountain, Mesozoic metavolcanic rocks capped locally by remnants of the Pliocene basalts described at Stop 3 .

From Stop 8, continue east down Lake Mary Road, ignoring a right turn to Lake Mary after $\sim 0.9$ mile, and, after another 0.6 mile, turn right (east) down Old Mammoth Road (03233/41648). In $\sim 0.6$ mile, a trailhead is marked on the right at the second switchback (03242/41652). Park below that switchback, walk back to the trailhead, and follow the trail for 300 $m$ to a fine viewpoint directly below Mammoth Rock, a white monolith of Late Paleozoic marble.

Stop 9. View from the base of Mammoth Rock (03244/41650). A few hundred meters north, the easternmost coulee of Mammoth Mountain trachydacite rises $90 \mathrm{~m}$ above Mammoth Meadow. Locally called "The Bluff," the flow forms a till-strewn flat-topped bench and is the topographically lowest of four coulees east of Twin Lakes. A feldspar-rich biotite-hornblende trachydacite typical of Mammoth Mountain, the flow has 66 percent $\mathrm{SiO}_{2}$ and gave a ${ }^{40} \mathrm{Ar} /{ }^{39} \mathrm{Ar}$ age of $73 \pm 1 \mathrm{ka}$. Farther north, several late Pleistocene domes can be seen (fig. 25). To the northeast, a belt of nested Tioga (MIS 2)

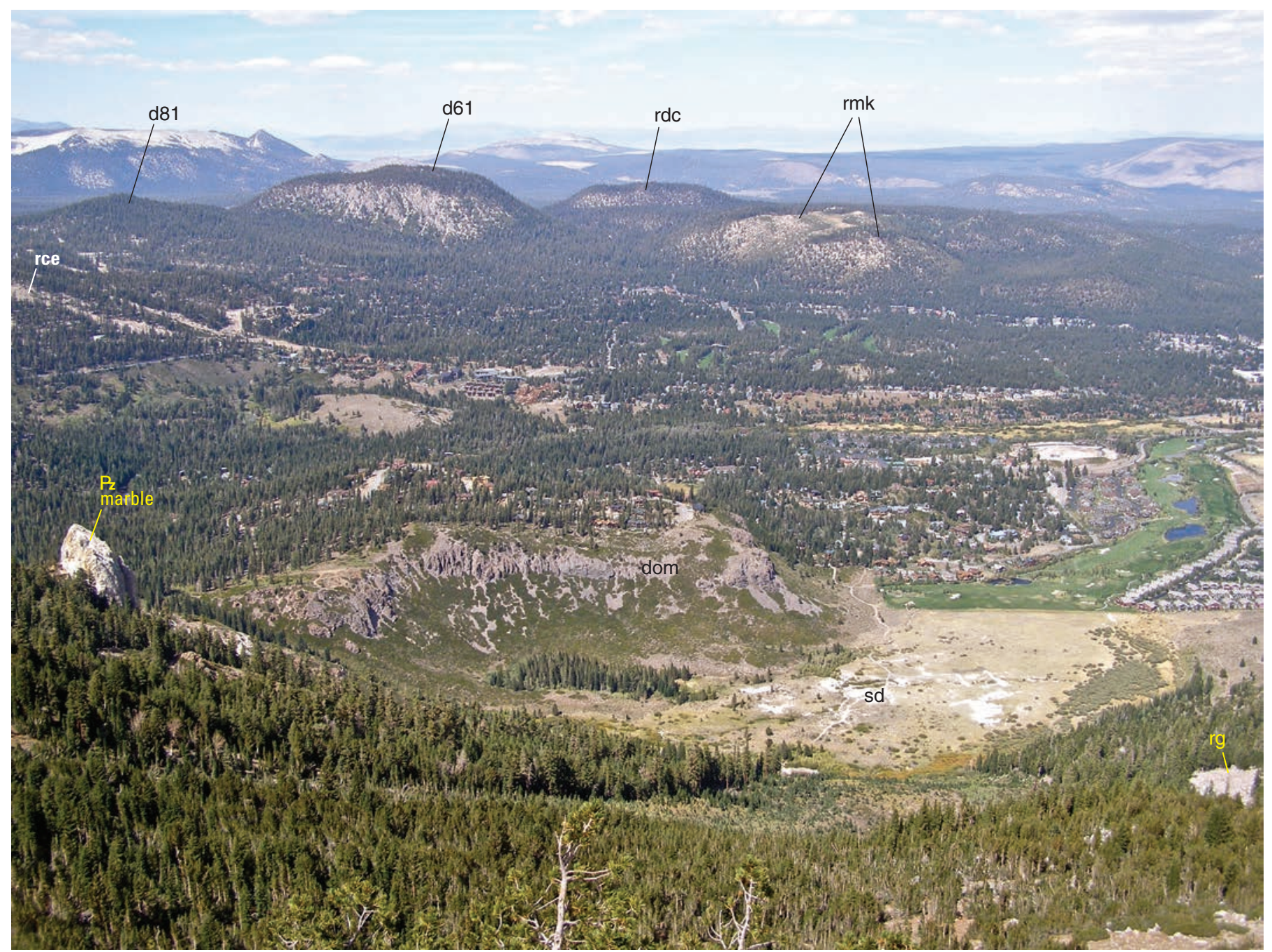

Figure 25. Town of Mammoth Lakes and four adjacent late Pleistocene (110-87 ka) lava domes. Domes 2781 (unit d81) and 2861 (unit d61) consist of Mammoth Mountain trachydacite, whereas the Dry Creek and Mammoth Knolls domes are Long Valley highsilica rhyolite. Background scarp is northwest wall of Long Valley Caldera, in the west moat of which the four domes erupted. In left foreground, Mammoth Rock is white spire of Paleozoic marble. In lower center is 90-m-high scarp (called "The Bluff"), which is easternmost coulee of Mammoth Mountain trachydacite ( 73 ka). Barren part of Mammoth Meadow in center-right foreground is partly covered by postglacial travertine and sinter. View northward from surface of Red Mountain (see fig. 20). 
moraines begins in town and extends beyond it. In the northeast distance is the forested resurgent uplift, which consists almost completely of early postcaldera rhyolite (750-640 ka). The marble of Mammoth Rock overlies stratified hornfelsed siltstone and quartzite of Mississippian age, and the marble is in steep fault contact with Mesozoic metavolcanic rocks on its southwest. Just below the trail, a leucogranite dike (70 percent $\mathrm{SiO}_{2}$ ) $20 \mathrm{~m}$ thick intrudes the hornfelsed strata. The dike may be an offshoot of the Round Valley Peak Granodiorite, a Late Cretaceous pluton that crops out boldly on the mountain wall southeast of Mammoth Rock and extends $15 \mathrm{~km}$ southeast, separating thick sections of deformed Paleozoic metasedimentary and Mesozoic metavolcanic rocks (Rinehart and Ross, 1964). Patches of travertine are preserved along and just below the trail here, as well as on the meadow floor below.

This is the last stop in the Mammoth area. Return to Convict Lake, Toms Place, or your campsite or lodging of choice. We recommend visiting Stop 10 at this time because afternoon light is much better than morning light for this view. From Toms Place, drive 3.8 miles west on Crowley Lake Drive to its intersection (03463/41584) with South Landing Road (which provides alternative access from Highway 395). Alternatively, from the Convict Lake road at Highway 395, the South Landing overpass is $6.5 \mathrm{~km}$ southeast; turn right there and drive 0.9 mile uphill through the village of Lake Crowley on South Landing Road to its T-intersection with Crowley Lake Drive. Continue 0.8 mile west on Crowley Lake Drive from the South Landing Road intersection and park at Crowley Lake Park playground or (just beyond) near the firehouse.

Stop 10. Caldera vista, paleoshorelines, and Bishop Tuff knolls from Crowley Lake Park (034535/41592). On both sides of the outlet arm of Lake Crowley, gently sloping smooth terraces contrast with the raggedly eroded Bishop Tuff (fig. 26). The terraces were wave-planed during the late middle Pleistocene highstand of the caldera lake, and they are mantled by sheets of well-rounded beach gravels, both loose shingle and carbonate-cemented sandy-pebbly beachrock. A wave-cut shoreline scarp of Bishop Tuff stands as high as $50 \mathrm{~m}$ above the terrace and extends several kilometers north of the outlet arm. Highstand lake gravels are continuous for $13 \mathrm{~km}$, as far as Wilfred Canyon at the foot of Glass Mountain, beyond which the shoreline features are obliterated by younger alluvial fans. Near Wilfred Canyon the continuous highstand shoreline is $\sim 185$ $\mathrm{m}$ higher in elevation than at the outlet arm, showing that the

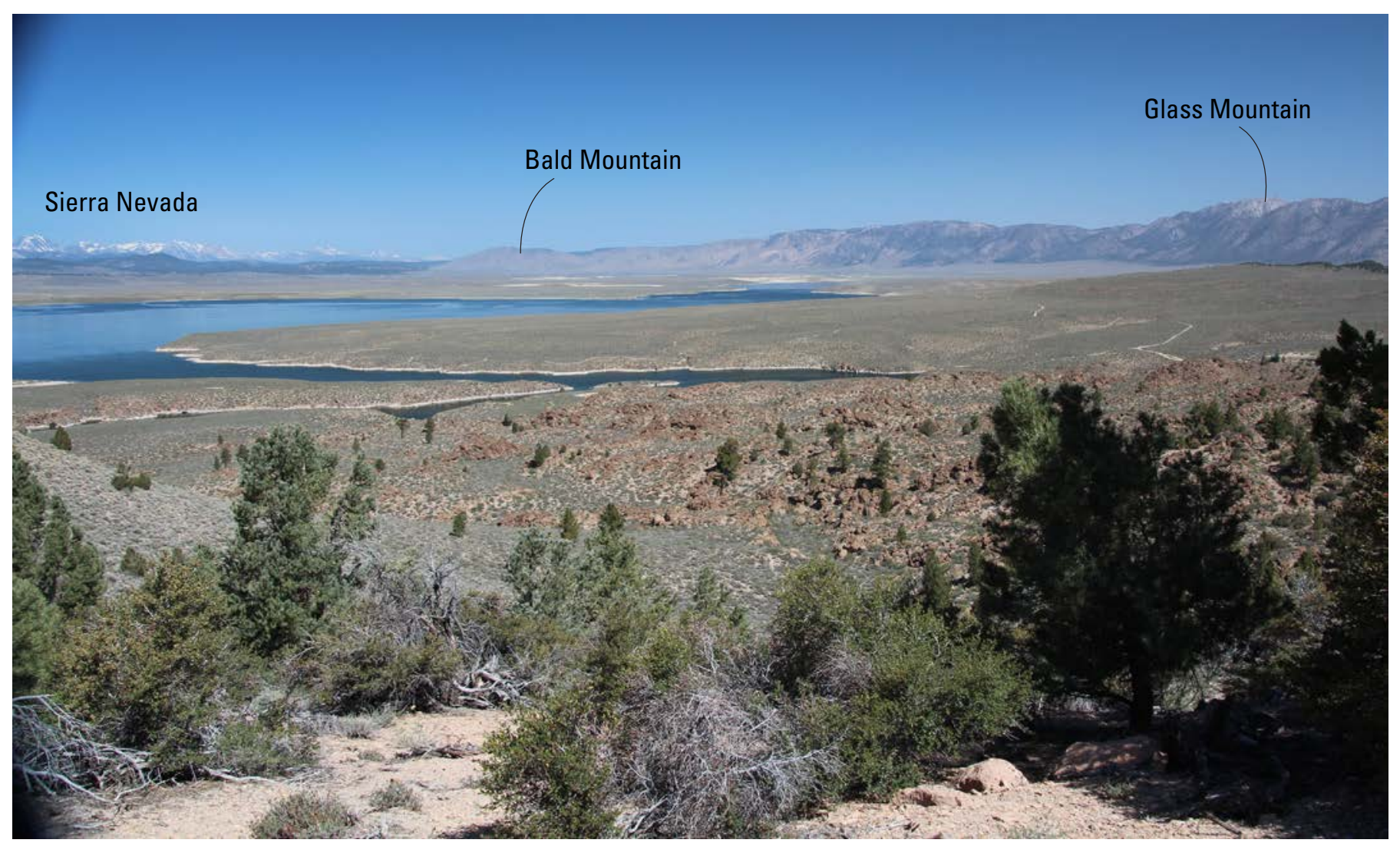

Figure 26. Photo of outlet arm of Lake Crowley reservoir. View northward from knoll 2224 at north rim of Little Round Valley. Outlet arm trends east toward dam at head of Owens River Gorge, along the very same channel that drained Long Valley's Pleistocene caldera lake $\sim 150 \mathrm{ka}$. Raggedly eroded Bishop Tuff in right foreground contrasts with smooth wave-planed terraces that were submerged by the caldera lake on both sides of the outlet arm. White exposures beyond reservoir in Long Valley lowland are lake-silt deposits of the Pleistocene caldera lake, more than 700 m thick in the subsurface. At lower left, the lower end of the Crooked Creek tributary is drowned by the reservoir (as it also had been by the Pleistocene lake). Bald Mountain and Glass Mountain rise above the north-tonortheast wall of the caldera. 
shoreline has been tectonically tilted $\sim 0.8^{\circ} \mathrm{S}$. since the lake drained soon after $150 \mathrm{ka}$ (Hildreth and Fierstein, 2016b). The southward tilting is toward the Round Valley Fault, which farther south trends north-south and has 2,000 m of steep range-front relief. Here, the fault wraps around to trend N. $65^{\circ} \mathrm{W}$., exhibits both normal and dextral displacement, and dips less steeply.

To the right, a chain of ignimbrite knolls consists mostly of Bishop Tuff package Ig1E but is capped by thin remnants of Ig2E. [For Bishop Tuff stratigraphic terminology, see figure 6.] Much of Ig2E shingled off downslope over the smooth, hot, gassy surface of Ig1E, thickening southward to as much as $115 \mathrm{~m}$ at Pleasant Valley (Stop 15). Stripping of nearly all of Ig2E and part of Ig1Eb from the proximal region suggests at least $50 \mathrm{~m}$ of erosive reduction of the primary ignimbrite surface on the caldera-facing slope. The chain of knolls also suggests an ignimbrite slope of $\sim 2^{\circ}$ NNE. toward the head of Owens River Gorge, opposing the southward slope of the tilted highstand north of the gorge. The slope suggested by the knolls could reflect primary run-up of the ignimbrite against the granitic range front or, alternatively or additionally, differential compaction of thicker ignimbrite that filled the precaldera drainage axis.

\section{End of Day 1}

\section{Day 2. Bishop Tuff}

\section{Stop 11. Sherwin Till at Rock Creek Gorge (03538/41576). On Highway 395 from the turnoff for Toms Place, drive 0.9 mile east, turn right on Lower Rock Creek Road (03534/415785), continue 0.3 mile, and park at a wide left-side pullout where Rock Creek takes a big meander.}

The roadcut is in Sherwin Till (MIS 22; 900-866 ka). Glacial erosion in the Sierra Nevada is likely to have been most profound during the Sherwin glaciation. Not only was the Sherwin advance greater than any subsequent glacial advance in the Sierra, but MIS 22 was the first of five great global episodes of ice accumulation (along with MIS 16, 12, 6 and 2) that followed the "Mid-Pleistocene Revolution" (Berger and others, 1993; Muttoni and others, 2003), which was the transition from higher-frequency loweramplitude climatic oscillations to lower-frequency higheramplitude glacio-eustatic fluctuations. In the Sierra Nevada, glacial deposits of MIS 6 (regionally called the Tahoe glaciation) and 2 (Tioga glaciation) are well preserved, those of MIS 22 scattered and erosively subdued, and those of MIS $16(\sim 630 \mathrm{ka})$ and $12(\sim 410 \mathrm{ka})$ glaciations unreported and presumed obliterated during MIS 6 .

Sherwin Till is as thick as $200 \mathrm{~m}$ and derived almost entirely from granitic rocks. The glacier that carried it emerged from the canyon of Rock Creek only $4 \mathrm{~km}$ southwest of here. From the canyon's narrow mouth, the ice spread out 5-8 km eastward into a piedmont lobe at least $7 \mathrm{~km}$ wide. Locally it crossed Owens River Gorge, a $5-\mathrm{km}$ reach of which had been completely filled by Pliocene basalt, thus depositing till on both rims (see Stop 19). After the Sherwin episode, normal and dextral displacement on the Round Valley range-front fault promoted redirection of Rock Creek, which cut a northeast-trending canyon through a downdropped granitic buttress. Dextral offset of the apex of Sherwin deposits near the canyon mouth is at least $500 \mathrm{~m}$, giving an average strike-slip rate of $>0.6 \mathrm{~mm} / \mathrm{yr}$ since MIS 22. The piedmont lobe of Sherwin Till was thus displaced and bypassed, whereas emplacement of Tahoe and Tioga (MIS 6 and 2) glacial deposits was controlled by the new northeast drainage toward Toms Place. A long history of erosion has destroyed primary morainal landforms and reduced the Sherwin deposit to a rolling hill-and-gully terrain.

Stones in the till are $\sim 98$ percent granitic and range from pebbles to boulders as large as $2.5 \mathrm{~m}$, many of them grussy. Many of the subordinate metamorphic clasts $(10-50 \mathrm{~cm})$ are blocky and angular. The till matrix is rich in crystal sand, not unexpected for so proximal a granite-derived glacial deposit. We sieved 2-kg samples of till matrix (excluding clasts larger than $8 \mathrm{~mm}$, which make up at least half by weight of the bouldery till) from two roadcut exposures of the type Sherwin Till along Rock Creek. Both matrix samples are dominated by sand and granules (median diameter 1.5 and $1.7 \mathrm{~mm}$, respectively), and both are poor in fines ( 0.5 and 1.7 weight percent finer than 1/16th mm). Eroded scarps of Bishop Tuff overlie Sherwin Till deposits north and east of here.

As one continues south down Rock Creek, the canyon walls are in Sherwin Till for 2.2 miles before the road and creek enter a granodiorite gorge. About 0.3 mile into the granodiorite gorge, the road crosses back to the right bank of the creek (03555/41541). Here a large pullout on the right permits parking for access to a foot trail that follows Rock Creek $\sim 7 \mathrm{~km}$ downhill to the next road crossing at Paradise Camp. The hike would take 2-3 hours for this reach, which has fine exposures of granitic and metasedimentary rocks and a range of welding styles in the Bishop Tuff. Vehicles can be sent ahead to pick up one-way trail hikers at Paradise Camp.

From the trailhead carpark and stream crossing, continue southward (now uphill on Lower Rock Creek Road) for 0.7 mile to a roadcut in the Bishop Tuff at the road's high point; continue 0.1 mile farther to a carpark on the right (03560/41529). Then cross the road and walk $150 \mathrm{~m}$ north to the gorge rim. Be alert for traffic!

Stop 12. Rock Creek gorge high rim viewpoint (03561/41531). Thin nonwelded tuff wedges out against the granodiorite hill here. The gorge is $160 \mathrm{~m}$ deep, cut through Triassic granodiorite with pendants of Paleozoic marble and fine-grained hornfels. The ignimbrite steeply drapes the ridge of basement rocks, thickening from nil to $160 \mathrm{~m}$ within $600 \mathrm{~m}$ downstream. Black columns of densely welded vitrophyre crop out near stream level 1-3 km downstream. 
Sherwin Till blankets the granodiorite along the west rim of the gorge and on the east rim upstream. On the lower east wall of the gorge $\sim 800 \mathrm{~m}$ upstream from our viewpoint, a wedge of Sherwin Till $\sim 35 \mathrm{~m}$ thick extends to within $20 \mathrm{~m}$ of present-day stream level, preserved beneath a talus of ignimbrite blocks. The till remnant shows that Rock Creek gorge was incised nearly to its present depth before the Sherwin glaciation. That the same is true for Owens River Gorge will be demonstrated at Stop 19.

Back to the vehicles, and continue south down Lower Rock Creek Road across the Volcanic Tableland, the eroded and warped surface of Bishop Tuff, which here slopes $4^{\circ} \mathrm{SW}$. toward Round Valley and 1-2 ${ }^{\circ}$ S. toward Bishop. About half of the gradient appears to have been imposed by tectonic steepening since the eruption at $767 \mathrm{ka}$. Owens Valley and Round Valley have been subsiding since the late Pliocene, and the Round Valley range-front fault on your right has 2,000 $\mathrm{m}$ of relief. The tableland surface here is studded with fumarolic mounds where thick sections of devitrifying welded tuff supplied gas to overlying zones of vapor-phase crystallization (Bateman, 1965; Sheridan, 1970). The fumarolically indurated mounds rise 5-15 m (and rarely as much as $30 \mathrm{~m}$ ) above the surrounding plateau surface of moderately welded tuff, giving a minimum measure of the long-term reduction of such surfaces by deflation and sheetwash.

Pick up Rock Creek gorge hikers at Paradise Camp trailhead and carpark, about halfway down the grade. While waiting for hikers, postcaldera alluvial deposits can be examined in roadcuts near Paradise Camp; and residential side roads afford fine vistas of Owens and Round Valleys and the Sierra Nevada.

In the city of Bishop, turn left from Highway 395 onto Highway 6 (03765/41373), reset odometer, bypass the town of Laws at 3.6 miles, and 4 miles farther north turn left (at 7.6 miles) onto Rudolph Road (03807/41461), which in 1 mile leads straight into a big white pumice quarry.

Stop 13. Chalfant Valley pumice quarry (03792/41466). Excavations here provide fine exposures of plinian pumice-fall

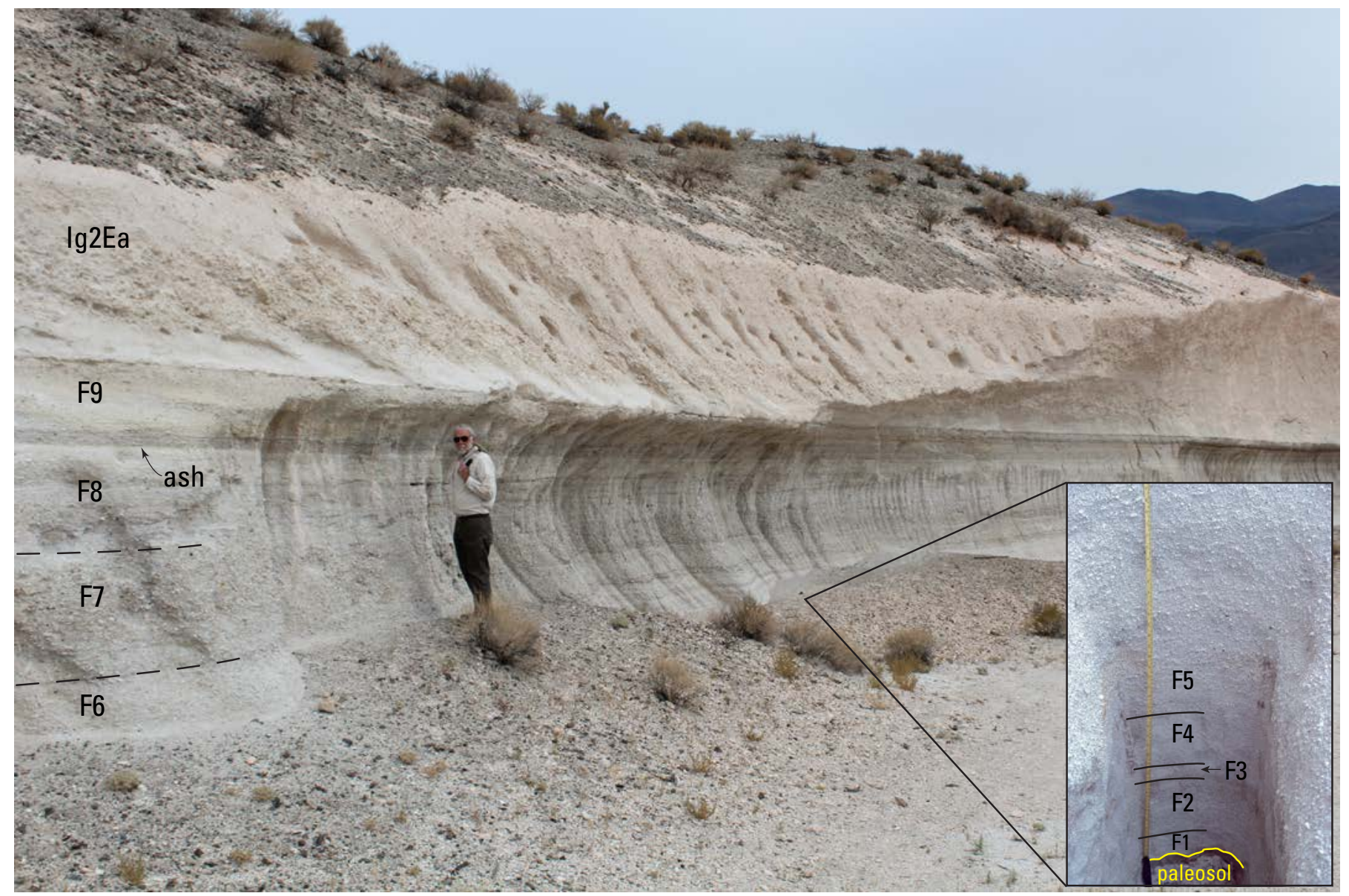

Figure 27. Bishop Tuff plinian fall deposit at Chalfant Valley pumice quarry (Stop 13). Subdivision into nine fall units (F1-F9) is widely recognizable east and southeast of the caldera (Wilson and Hildreth, 1997). Thickness of F6-F9 part of section continuously exposed in quarry is $\sim 3.5 \mathrm{~m}$. F8 and F9 are separated by a few centimeters of white fines-bearing ash that accumulated during a short break in plinian deposition; see also figure 28 . Where excavated to base of F1 (inset), complete fall section here is $5.4 \mathrm{~m}, \sim 42 \mathrm{~km}$ southeast of the initial vent site. Fall deposit is overlain by several meters of nonwelded ignimbrite package Ig2Ea, in which faint stratification reflects episodic deposition as a series of pulses. Spade work and photo for inset by C.J.N. Wilson, master excavator. 
deposits and distal nonwelded ignimbrite. The fall deposits, here $5.4 \mathrm{~m}$ thick (fig. 27), were subdivided by Wilson and Hildreth (1997) into nine units (F1-F9), most of which are identifiable at all exposures west of the White Mountains (fig. 6). The underlying paleosol and F1-F5 are beneath the floor of the quarry. Layer-by-layer deposition was from an eruption plume estimated to have increased in height from 18 to $45 \mathrm{~km}$ and to have lasted 5-6 days, most of the material having been blown eastward as ashfall. Little fine ash is present in the fall deposits here, $42 \mathrm{~km}$ southeast of the opening vent site, owing to winnowing in the eruption plume. Vertical changes in pumice-clast size reflect to a first order the power of the eruption. The sparser, smaller and denser, lithic fragments are equivalent aerodynamically to co-deposited pumice. Unlike the flow deposits, the only opportunity for lithics to be incorporated in the fallout was at the vent. Scrutiny of the lithic assemblage in the fall deposits has thus been used to identify the initial vent site in the south-central part of the caldera and to recognize changing vent sites later in the eruptive sequence (Hildreth and Mahood, 1986). Recognition of the first appearance of rhyolite lithics just below the F8-F9 contact, for example, signals vent migration eastward into the Glass Mountain pyroclastic fan. The first appearance and subsequently increasing proportion of rhyolite in the lithic suite provided key stratigraphic markers for both fall and flow deposits (Wilson and Hildreth, 1997).

Crystal content of the fall deposits increases upward, although this is not generally true of the co-deposited pumices. This reflects the expectation and inference that, with increasing column height, the mean sizes of all clast types increases, and, for F6-F9, the range in fall velocities represented by deposition at this particular distance and azimuth from the vent coincided with that of the mode $(0.5-2 \mathrm{~mm})$ of the phenocryst population. Low-angle cross-bedding in some of the fall deposits is interpreted as induced by strong swirling winds during deposition of the falling pyroclasts (Wilson and Hildreth, 1998), as promoted by atmospheric inflow toward buoyant thermal updrafts above concurrent pyroclastic flows.

No break is recognized in the F1-F8 sequence. The fineash-bearing layer a few centimeters thick at the F8-F9 contact may represent the only hour-long pause in the eruption. By comparing accumulation rates of historic eruptions with thickness and lithic-dispersal characteristics comparable to each of the Bishop fall units, we estimated that the F1-F8 sequence took $\sim 90$ hours and F9 an additional $\sim 26$ hours (Wilson and Hildreth, 1997, tables 3, 4; Hildreth and Wilson, 2007).

The ignimbrite is manifestly ill-sorted, with grain sizes ranging from dust to blocks, reflecting transport in concentrated pyroclastic flows that provided little opportunity for mixing with air or consequent winnowing of fine and low-density components. Pumice clasts can be rafted buoyantly to far greater distances than their size equivalents in the fallout. The concentrated deposits also retain sufficient heat that thermal oxidation is common and welding is typical of thicker, more proximal sections. The ignimbrite here was deposited in a series of pulses that produced meter-scale layering commonly defined by trains of pumice clasts. Accumulation was seldom slow enough to allow formation of clear flow-unit boundaries nor continuous enough to produce homogeneous material. In contrast to the fall deposits, stratification cannot be traced for more than tens to hundreds of meters around the quarry. Correlation of ignimbrite between different exposures was done by defining multi-flow packages (fig. 6) that share distinguishable populations of pumice and lithics (Wilson and Hildreth, 1997; Hildreth and Wilson, 2007).

A distal flow of package Ig1Eb, only 1-2 m thick, is intercalated here in F8 (fig. 28). Like the fall layers below, it contains no rhyolite lithics, no pyroxene-bearing pumice, and no crystal-rich pumice. All three of these components are present in F9, however, and in package Ig2Ea, which here overlies part of F9. North of here, Ig1Eb thickens into a wedge of similar material $>80 \mathrm{~m}$ thick, much of which is densely welded. West of here, Ig2Ea forms the lower part of the Volcanic Tableland and crops out along the Chalk Bluff escarpment for $\sim 10 \mathrm{~km}$ (as far as Stop 15).

Elsewhere, F9 is as thick as $207 \mathrm{~cm}$ (4 times as thick as here) and is thought to have erupted synchronously with all the radial sectors of Ig2. Since Ig1E was entirely coeval with F1-F8 and Ig2 with F9, then the entire eruption took less than six days. The importance of the chronostratigraphic framework is threefold (Wilson and Hildreth, 1997, 2003; Hildreth and Wilson, 2007; Chamberlain and others, 2015). (1) Because much of the Bishop Tuff underwent devitrification and vapor-phase crystallization, many phenocrysts are exsolved, oxidized, or otherwise altered. Understanding of the emplacement sequence allows sampling of pumice from fresh glassy parts of every package.

(2) Proportions of pumice clasts of different characteristics or composition can be estimated by clast counts of each eruptive subunit, permitting assessment of the time-volumecompositional progress of the eruption. (3) Understanding the opening and migration of successive vents around the caldera and the changing proportions of different compositions that erupted from each vent segment provides evidence important for attempting to reconstruct the distribution of magma in the pre-eruptive reservoir and to model dynamic processes of magma withdrawal.

Return to Highway 6 and turn right (south); after 2.5 miles, turn right (west) on Jean Blanc Road (03806/414205) and go another 2.5 miles to its merger with Five Bridges Road (037636/41421). Pass through the gravel extraction plant and turn left on Chalk Bluff Road, which follows the Owens River and the south-facing scarp of Ig2E (Chalk Bluff) for $\sim 6$ miles to Pleasant Valley. The fall deposit can be dug out along this road but is scree-covered in all but two places. After $\sim 1.2$ miles on Chalk Bluff Road, prominent roadcuts expose fluvio-lacustrine sediments beneath the Bishop Tuff. Park at the meadow beyond and walk back to the roadcuts.

Stop 14. Precaldera lake sediments and Glass Mountain tephras below Chalk Bluff (03736/41420). Altogether, $27 \mathrm{~m}$ of sediments separate the base of the Bishop Tuff from the active Owens River. The Matuyama-Brunhes polarity transition ( $\sim 780 \mathrm{ka})$ was recorded (Liddicoat, 1993) in the sediments $2 \mathrm{~m}$ 
below the base of the Bishop fall deposit (767 ka). Above and below road level, several layers and lenses of rhyolitic pumice and ash, mostly water-reworked, have been compositionally correlated (Sarna-Wojcicki and others, 2005) with products of the large precaldera Glass Mountain edifice that forms the northeast wall of Long Valley Caldera. They reported laserfusion ${ }^{40} \mathrm{Ar}{ }^{\beta 9} \mathrm{Ar}$ ages of $1.13 \pm 0.19$ and $0.88 \pm 0.17 \mathrm{Ma}$ for sanidine from two of the layers.

Continue west along Chalk Bluff Road to Pleasant Valley where the Owens River emerges from the mouth of Owens River Gorge. Drive past the campground to a turn-around at the upper end of Pleasant Valley below Pleasant Valley Dam.

Stop 15. Pleasant Valley (03660/41415). In driving along the foot of Chalk Bluff, the fall deposit is only locally exposed and package Ig1 is absent, not having flowed this far. The ignimbrite scarp, which grows westward from $80 \mathrm{~m}$ to $115 \mathrm{~m}$, consists entirely of Ig2E. The top of an intermittently exposed ledge in midslope is the contact between packages Ig2Ea and b. Numerous field counts show the percentage of rhyolite fragments in the lithic fraction of the lower package to range from 11 to 22 percent and in the upper package from 38 to 57 percent. Much of the section is nonwelded but is capped by a welded zone in which material was emplaced at high enough temperature that cohesion of glassy particles ensued. Welding only at the top of the section is inconsistent with cooling of a package emplaced at uniform temperature. It is thus inferred that later flows were hotter, while earlier flows were cooler and failed to weld even though under greater load stress. Pleasant Valley exposes the thickest known section of Ig2E, which thins both eastward toward Chalfant Valley (Stop 13) and northwestward toward its caldera source, even though its welding intensity increases toward source. Water wells near Bishop show that Ig2E extends in the subsurface at least $15 \mathrm{~km}$ farther south than the Chalk Bluff scarp. The same plinian fall sequence (F1F9) visited at the pumice quarry at Stop 13 crops out beneath

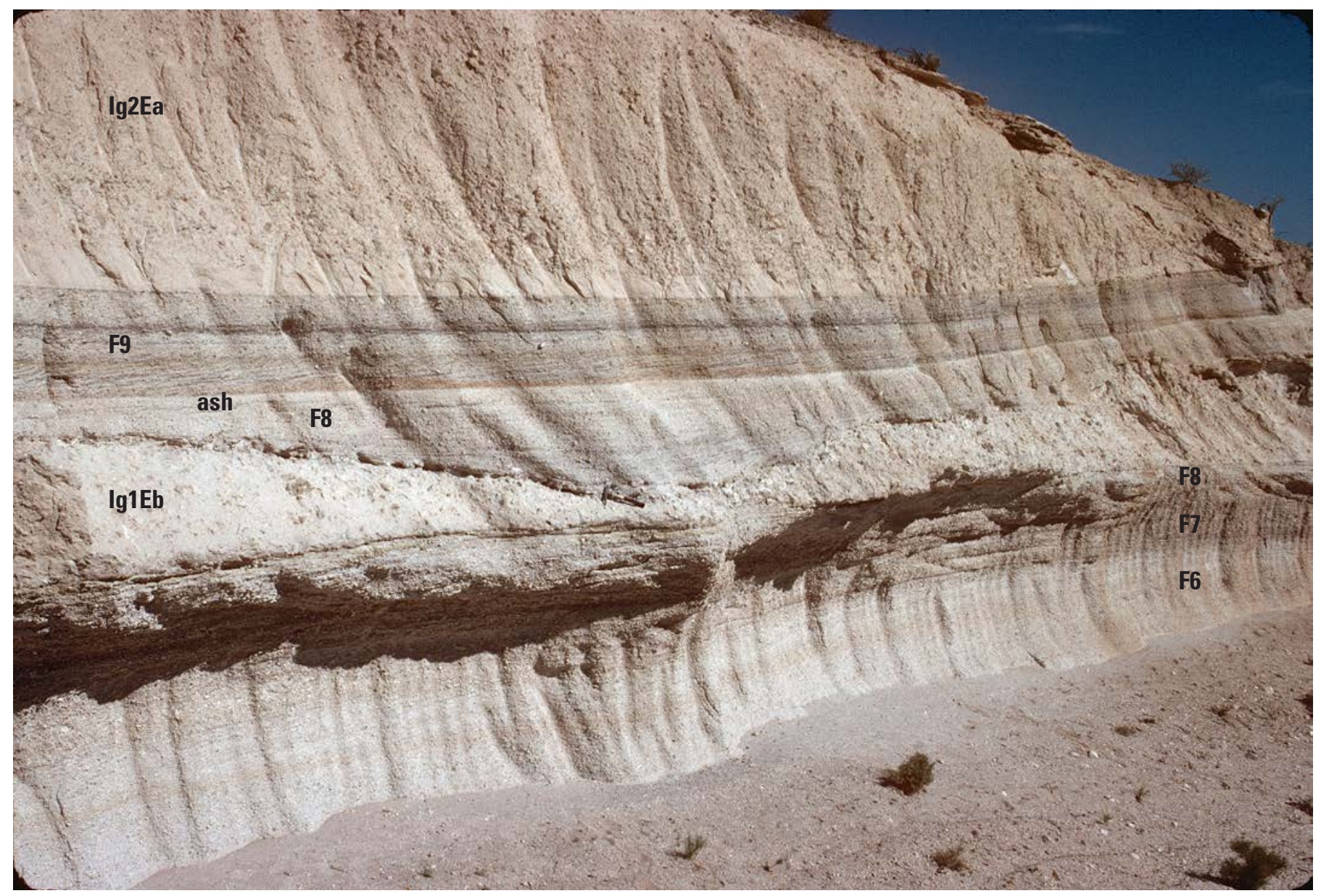

Figure 28. Thin distal bilobate flow unit of Ig1Eb synchronous with deposition of fall unit F8, at Chalfant Valley pumice quarry (Stop 13). Accumulation rates of fall deposits in comparably powerful historic eruptions inform an estimate of three hours for deposition of F8 (Wilson and Hildreth, 1997). As ignimbrite flowed $\sim 42 \mathrm{~km}$ from the vent area, many pumice clasts were buoyantly rafted, leading to preferential accumulation of low-density pumice at distal edges of flow units, as represented by the pumice rubble at margins of the Ig1Eb flow lobes intercalated here. Darker F9 is $65 \mathrm{~cm}$ thick and overlies a $3-5 \mathrm{~cm}$ layer of white ash that represents the only time break ( 1 hour?) recognized in accumulation of Plinian falls F1 through F9. Streaky to weakly cross-bedded aspect of F8 and F9 is attributed to penecontemporaneous mobilization of falling pyroclasts by swirling winds associated with concurrent pyroclastic flows (called hybrid fall deposits by Wilson and Hildreth, 1998). Note the pumice-poor 20-cm fine-grained basal layer of Ig2Ea above F9. 
Ig2Ea across the river, where it is $4.6 \mathrm{~m}$ thick ( 87 percent as thick as at more easterly Stop 13). The elevated terraces south of the river are thought to represent increased fluvial deposition during MIS 6 and 2 (Pinter and others, 1994; Hildreth and Fierstein, 2016b).

Follow paved Pleasant Valley Dam Road $\sim 1$ mile southward to Highway 395 and turn right. The highway skirts the margin of the Bishop Tuff for $\sim 5.5$ miles, and where it begins to climb the long ignimbrite slope from Round Valley toward the caldera, turn right on Gorge Road (03610/41453). After $\sim 1$ mile, turn left (north) at a T-intersection onto Aqueduct Road. Drive 1.1 miles north and park near a fumarolic mound on the left (03620/41470) and 200 $\mathrm{m}$ downslope from another mound on the right. The dams, aqueduct, and power houses along Owens River Gorge were built for the Los Angeles Department of Water and Power (LADWP) in the 1940s and 1950s. Crawl under the aqueduct pipe and walk $\sim 900 \mathrm{~m}$ east to the rim of Owens Gorge (03629/41470).
Stop 16. Welded fall deposit between packages of welded ignimbrite. On the east wall of Owens River Gorge, fall unit F9 (fig. 29) separates densely welded Ig1Eb (below) from Ig2E, which continues $75 \mathrm{~m}$ up to the rim. Ig2E contains rhyolite lithics, pyroxene phenocrysts, and common crystalrich pumice, unlike Ig1. F9 is here $\sim 35 \mathrm{~cm}$ thick, consists of coarse ash and medium lapilli, and, like the base of Ig2, is weakly to moderately welded. The paler lower part of Ig2 has a density minimum $\sim 1.65 \mathrm{~g} / \mathrm{cm}^{3}$, and the darker zone above attains a maximum of $\sim 2.3 \mathrm{~g} / \mathrm{cm}^{3}$ halfway up to the rim (fig. 10 of Wilson and Hildreth, 1997; fig. 9 of Wilson and Hildreth, 2003). Based on proportions of rhyolite in the lithic fraction, the lower $\sim 4 \mathrm{~m}$ of Ig2 here is Ig2Ea ( $\sim 15$ percent rhyolite) and the upper $\sim 70 \mathrm{~m}$ is $\operatorname{Ig} 2 \mathrm{~Eb}$ ( $\geq 40$ percent rhyolite).

Return to the vehicles. Continue uphill, bending around a large hill and descending a fault; then after 1.3 miles turn right onto a dirt road at 03617/41491, and park at the gorge

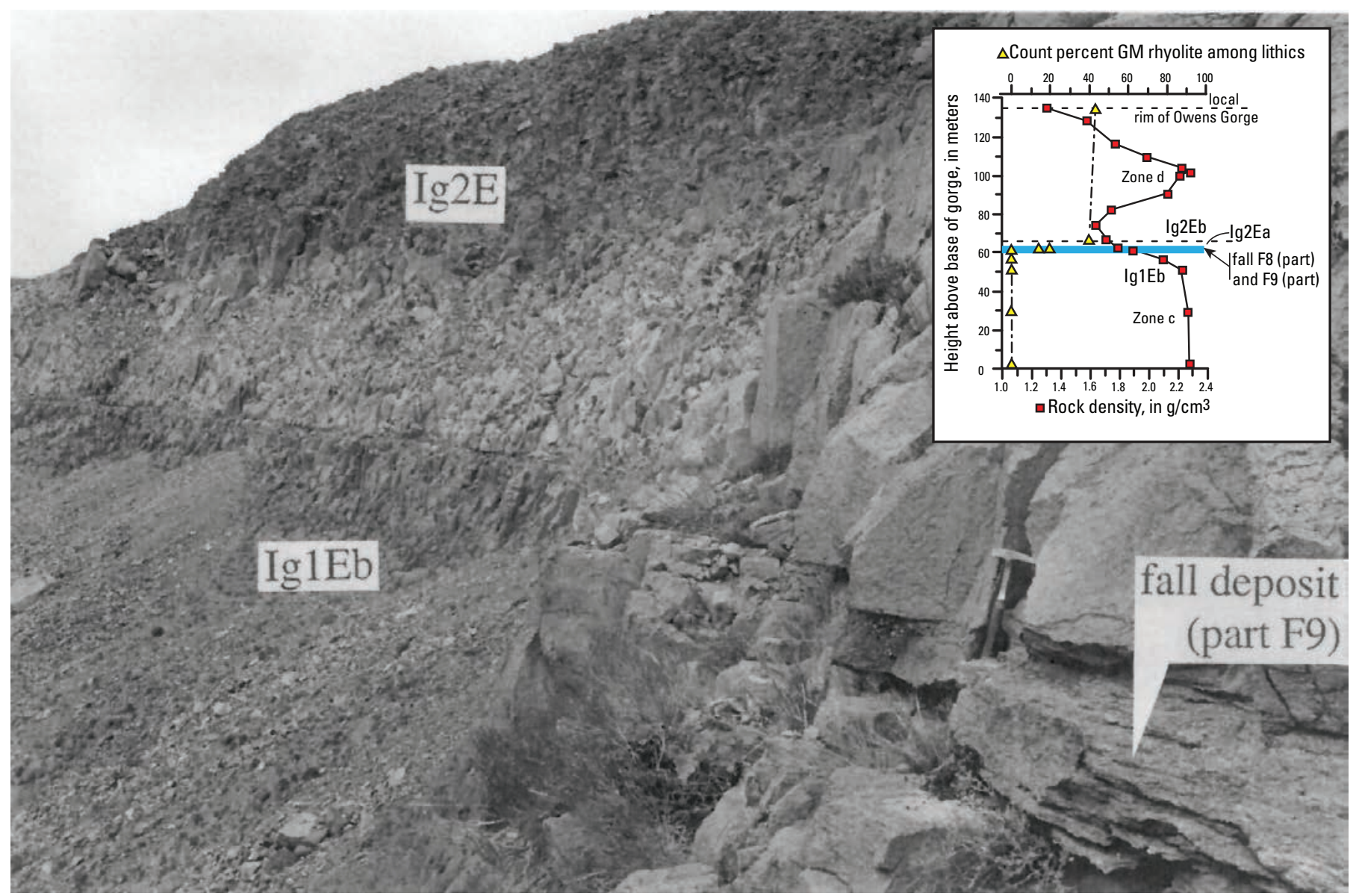

Figure 29. View of east wall of Owens River Gorge at UTM 03632/41469, showing 35-cm-thick remnant of Plinian fall unit F9, partly scoured, separating densely welded ignimbrite package Ig1Eb, below, from Ig2E, above. F9 is crudely stratified, moderately welded, and consists of coarse ash and medium pumice lapilli. Inset plot gives density profile and the percent of Glass Mountain (GM) rhyolite clasts in the lithic population counted for each sample. Interval $\sim 4 \mathrm{~m}$ thick with only 15 percent GM rhyolite in its lithic fraction is Ig2Ea. Density minimum $\left(1.65 \mathrm{~g} / \mathrm{cm}^{3}\right)$ is $\sim 10 \mathrm{~m}$ above the fall parting, in the pale lower part of $\mathrm{lg} 2 \mathrm{E}$, which is moderately welded and underwent vapor-phase crystallization. Dark-colored zones of $\lg 1 \mathrm{~Eb}$ (zone c) and middle of lg2E (zone d) are both densely welded (up to $2.3 \mathrm{~g} / \mathrm{cm}^{3}$ ). Photo from Wilson and Hildreth (1997); density profile is section $\mathrm{H}$ of Wilson and Hildreth (2003). 


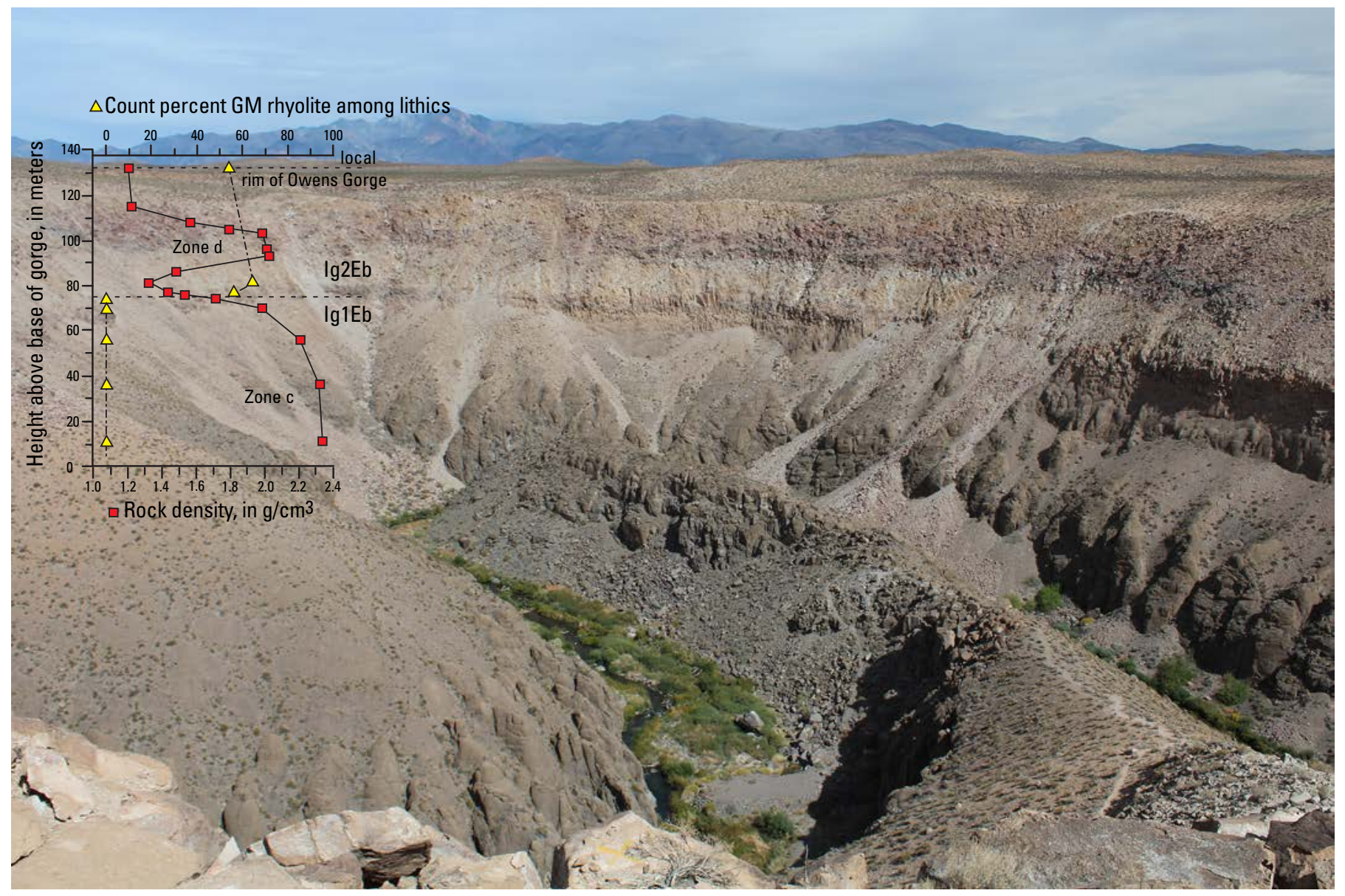

Figure 30. Entrenched hairpin meander in lower Owens River Gorge, here $130 \mathrm{~m}$ deep, is evidence that a formerly low-relief stream became deeply incised in response to southward tilting and steepening of the Volcanic Tableland. Inset plot gives density profile and the percent of Glass Mountain (GM) rhyolite clasts in the lithic population counted for each sample. Density minimum near base of pale central zone is $\sim 5 \mathrm{~m}$ higher than the lithologic change from package Ig1Eb to package lg2Eb (section $\mathrm{G}$ of Wilson and Hildreth, 2003). Fraction of Glass Mountain (GM) rhyolite in the lithic suite jumps abruptly at contact between ignimbrite packages. See additional discussion in text for Stop 17.

\section{rim (03621/41491). Tailings were left during aqueduct construction.}

Stop 17. Welding complexity and gorge incision. A hairpin meander in Owens River Gorge (fig. 30), here $130 \mathrm{~m}$ deep, is evidence of entrenchment of a formerly low-relief stream in response to southward tilting and steepening of the Volcanic Tableland. In addition to the arid climate and the weak drainage pattern elsewhere on the ignimbrite surface, the meandering course of the gorge weighs against its origin by headward erosion and, instead, by overflow of the Pleistocene caldera lake.

The ignimbrite section on the east wall is similar to that at Stop 16, except that the fallout interval was scoured away. At the Ig1/Ig2 contact, the percentage of rhyolite in the lithic fraction jumps abruptly from 0 to $\sim 50$ percent, implying that Ig2Ea is also absent, having shingled off southward. At Stop 16 (2 km south), Ig2Ea is $\sim 4 \mathrm{~m}$ thick and at Stop $15(10 \mathrm{~km}$ south) it is $>40 \mathrm{~m}$ thick.

The welding zones here are not what might be expected from superposition of two isothermal sheets of hot material, with a time break accounting for a lesser degree of welding around their interface. The minimum density level here does not correspond to any particular stratigraphic level nor with a plausible time break long enough to have permitted significant cooling. The dark-colored, most densely welded zones here have maximum densities of $2.35 \mathrm{~g} / \mathrm{cm}^{3}$ in $\operatorname{Ig} 1$ and $2.05 \mathrm{~g} / \mathrm{cm}^{3}$ in Ig2. Density at the contact is $\sim 1.7 \mathrm{~g} / \mathrm{cm}^{3}$ but decreases upward to as low as $1.35 \mathrm{~g} / \mathrm{cm}^{3}$ a few meters higher. The density minimum is thus $\sim 5 \mathrm{~m}$ higher than the base of $\operatorname{Ig} 2$, as was also true at Stop 16 (figures 8 and 9 of Wilson and Hildreth, 2003). We infer that residual heat from underlying $\operatorname{Ig} 1$ was sufficient to enhance the degree of welding in the most basal part of Ig2.

From Stop 17, return to paved Aqueduct Road and turn right (uphill). Drive 3.5 miles to a paved right turn (036075/415385) on road to LADWP Upper Powerhouse. The route passes a side road to the Middle Powerhouse at 0.7 mile and swings right across a large arroyo at 3.0 miles. Park near the gate (usually locked) after 0.2 mile on the Upper Powerhouse Road (03609/41541). 
Stop 18. Columnar jointing and unique intra-ignimbrite erosion. In a roadcut opposite the carpark, a laminated interval of wind-disturbed fallout as thick as $40 \mathrm{~cm}$ occupies a shallow swale scoured into the underlying ignimbrite and has itself been scoured by the overlying one. No other evidence of erosion or reworking within the ignimbrite sequence has been found elsewhere in the entire Bishop Tuff. Sparse rhyolite lithics are present in the fall bed and trace amounts in the top $5 \mathrm{~m}$ of the ignimbrite below it. Beneath this is $140 \mathrm{~m}$ of rhyolite-free Ig1. Within the $\sim 14 \mathrm{~m}$ of Ig2 above the fall bed, rhyolite lithic abundance increases to as much as 65 percent of the lithic suite at the rim. The brief time break indicated by the erosive interval is therefore at roughly the same time-stratigraphic position as the fineash layer seen between F8 and F9 in the Chalfant Valley quarry at Stop 13.

The upper tens of meters of ignimbrite are strongly vapor-phase altered and recrystallized here (affecting both packages), a result of vigorous fluid flux from the thick section of densely welded devitrified Ig 1 below. Across the gorge, vertical, inclined, horizontal, and rosette columns are well developed in the ignimbrite. The wide vertical columns exposed on the lower walls formed in densely welded tuff that cooled slowly in the interior of the sheet at a considerable distance above the unexposed base. Higher columns are narrower and curve with respect to fractures that transported hot gas during rapid cooling and pervasive ${ }^{18} \mathrm{O}$ depletion of the groundmass (Warner Holt and Taylor, 1998).

One can walk down the road below the gate, descending through the vapor-phase zone into devitrified eutaxite, eutaxite with glassy fiamme, and monotonous densely welded devitrified tuff.

Return to paved Aqueduct Road and go right (north) for 2.1 miles to a complex junction near a concrete surge tank (keeping left at an earlier fork at 1.8 miles at 03588/41559). From the surge tank junction (03586/41564), go left on a rough road over a low hill and, after 0.6 mile, turn right onto a dirt road $(035765 / 41567)$ that climbs through ignimbrite outcrops to the gorge rim (03582/41569). There is one narrow rough spot midway up this road, but (with caution) ordinary cars have made it. Park at road's end near the gorge rim.

Stop 19. Basement high draped by Bishop Tuff. Across the gorge, which is here $\sim 250 \mathrm{~m}$ deep, a wall of Triassic granodiorite is $180 \mathrm{~m}$ high and is draped by a Pliocene stack of $\sim 15$ basaltic lava flows that dip $\sim 20^{\circ} \mathrm{WSW}$., all the way to the modern gorge floor (fig. 31). Just up-canyon, the basalt is as thick as $190 \mathrm{~m}$ and is overlain by $60-100 \mathrm{~m}$ of Bishop Tuff, which extends to the rim on both sides. Both basalt and ignimbrite thin markedly where they drape over the granodiorite high, but both thicken again farther downstream. Between the 3.3-Ma basalt and the 767-ka Bishop Tuff, exposures of white granitic boulders on both walls represent deposits of Sherwin Till $\sim 25 \mathrm{~m}$ thick, which were deposited by a Sierran glacier during MIS 22 (900-866 ka) and (or) 20 (814-790 ka) (Lisiecki and Raymo, 2005). Because most of 30-km-long Owens River Gorge is walled only by Bishop Tuff, it has not been widely appreciated that the gorge dates from the Miocene (Hildreth and Fierstein, 2016b). The Owens River had crossed the later site of the caldera from sources farther north and had cut the deep granodiorite gorge before the 3.3-Ma basalt filled it from floor to rim. Because the Sherwin glacier crossed this reach of the gorge and because the Bishop Tuff is nowhere inset against either the granodiorite or the rubbly basalt, it is clear that the 5-km-long basalt-blocked reach of the gorge was not re-excavated until after emplacement of the Bishop Tuff. Between 3.3 Ma and $767 \mathrm{ka}$, the Owens River was diverted to nearby Rock Creek along a channel later buried by the Bishop Tuff. The earliest ignimbrite, distinctive subpackage Ig1Ea, as thick as $80 \mathrm{~m}$, was completely blocked by the basement high, confirming that the basalt-filled reach had not, by then, been re-excavated. Several thin fall beds are intercalated within Ig1Ea, which overlies only $44 \mathrm{~cm}$ of fall deposits (F1 and lower F2), showing that pyroclastic flows began very soon after onset of the eruption (Wilson and Hildreth, 1997). After the caldera collapse, the upper Owens River terminated in an intracaldera lake that slowly filled a profound depression initially more than $700 \mathrm{~m}$ deep. Only after the lake filled with $700 \mathrm{~m}$ of sediment, reaching its spillpoint $\sim 150 \mathrm{ka}$, was the gorge reincised through the ignimbrite and the basalt (Hildreth and Fierstein, 2016b).

Return to the main dirt road, turn right (northwest), drive 0.8 mile to a 3-way junction (03565/415735), and turn left. With ragged Bishop Tuff on the right and a 100-m-high hill of Sherwin Till on the left, drive one mile to Highway 395 at Sherwin Summit and turn right. Either proceed to Stop 21 via Toms Place or plan on 2-3 hours for Stop 20.

To reach Stop 20, a high-clearance vehicle, preferably one with 4-wheel drive, is necessary. From Toms Place intersection, cross Highway 395 northward. In $100 \mathrm{~m}$ turn left at the mailboxes and stay on sinuous Owens Gorge Road for 4 miles to Long Valley Dam (03494/416125), which has impounded Lake Crowley reservoir since 1941. Where the road crosses the dam, indurated layers of beachrock on the left-bank rim of the gorge mark the edge of the highstand terrace of the middle Pleistocene caldera lake. Drive 0.25 mile beyond the dam and turn sharply left (034975/41615) onto a winding dirt road. Now on a wave-planed highstand lake terrace, keep right at minor intersections and cross two big arroyos (the second one rutted and somewhat challenging), and after $\sim 1$ mile, zigzag left-then-right at a complex intersection (03489/416265). Continue north for another 0.45 miles (with a Pleistocene beach cliff of Bishop Tuff on the right), go straight across an intersection, and proceed 0.2 mile farther to the road's end (034835/416345) at the cliff rim above Lake Crowley. Walk down a trail to the modern beach and find numerous pillars of indurated nonwelded ignimbrite etched out by wave 

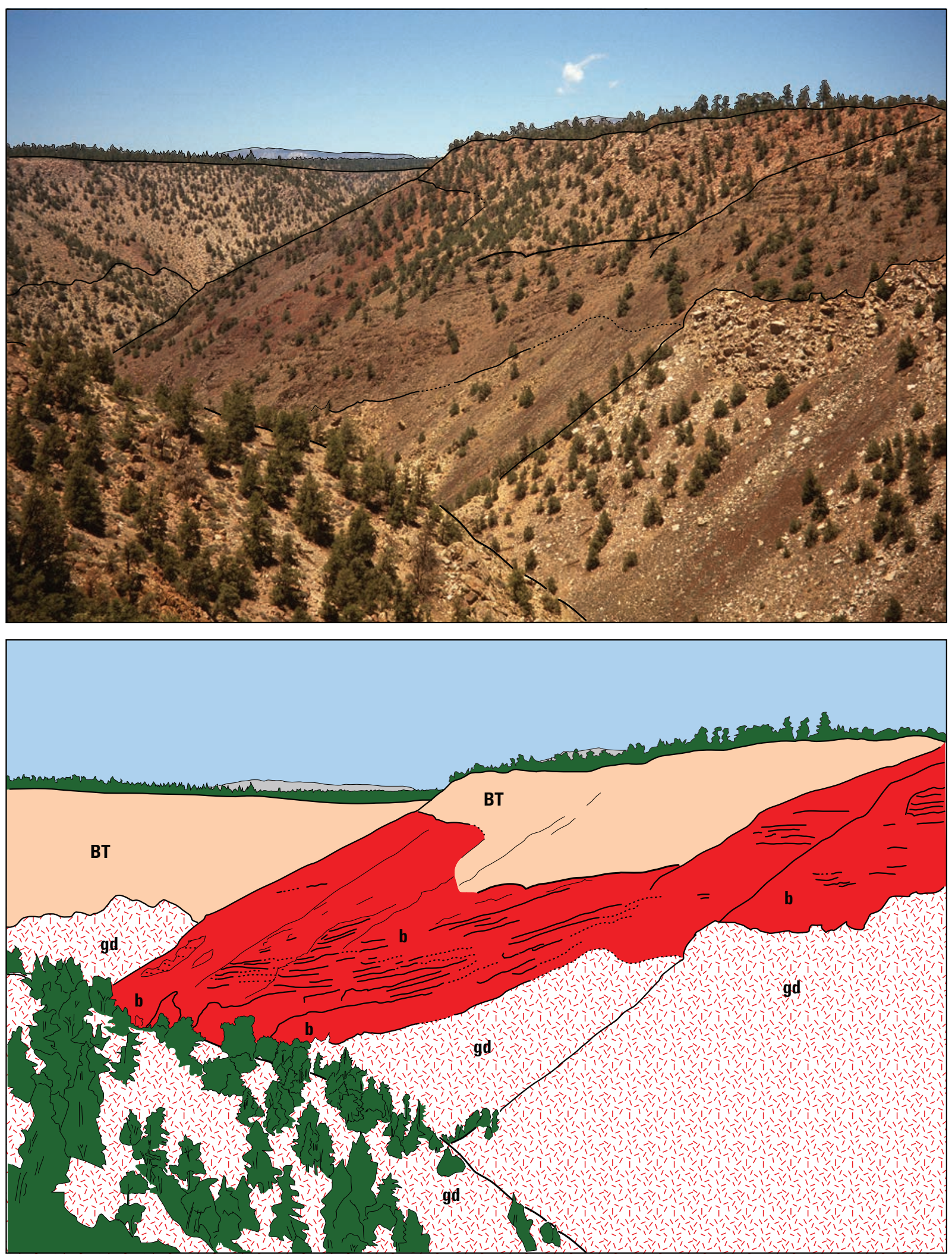

Figure 31. View upstream from right-bank rim of Owens River Gorge near Stop 19. Gorge depth here is $\sim 250 \mathrm{~m}$. On opposite (left-bank) side, granodiorite wall in right foreground is $180 \mathrm{~m}$ high and is draped by stack of $\sim 15$ basaltic lava flows that dip $\sim 20^{\circ}$ WSW, all the way to gorge floor. Canyon-filling basalt is as thick as $190 \mathrm{~m}$ at left center and overlain by 60-100 m of Bishop Tuff, which extends to rim on both sides. Basalt (b) and Bishop Tuff (BT) thin markedly to right where they drape over the granodiorite (gd) high, but both thicken again farther downstream. From Hildreth and Fierstein (2016b). 


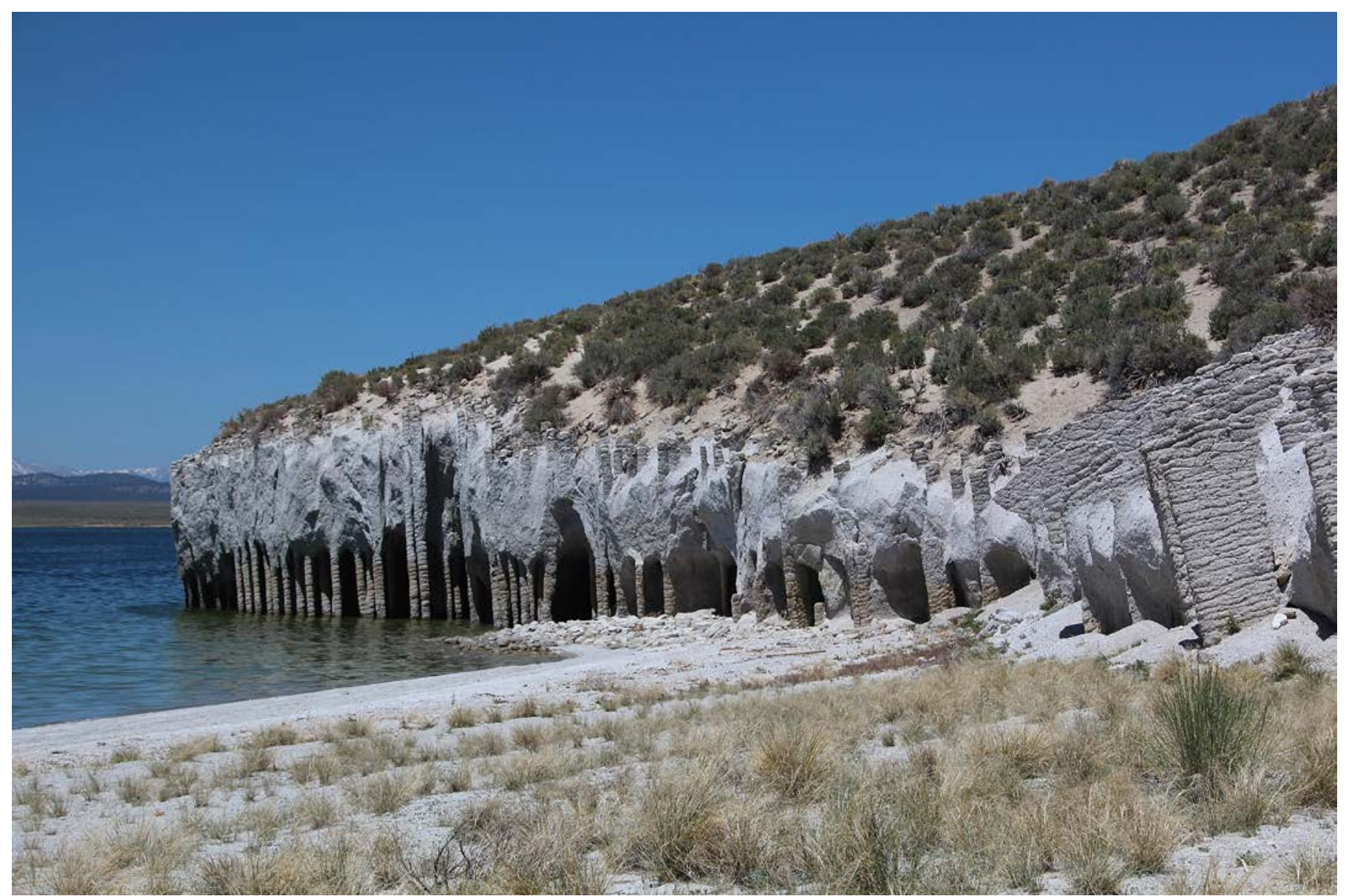

Figure 32. Photo of zeolitized pillars in nonwelded Bishop Tuff, etched out by wave action at Lake Crowley reservoir (which dates from 1941). Most pillars are near vertical, $20-50 \mathrm{~cm}$ in diameter, and 3-8 m high. Some sets are inclined, and tabular sheets of similarly indurated tuff (as at right) are also common. The features are recognized only in near-basal exposures of nonwelded ignimbrite, here in the earliest package emplaced, Ig1Ea of Wilson and Hildreth (1997).

action of Lake Crowley. If all this is too complicated, hire a boat at South Landing and visit the pillars from the reservoir.

Stop 20. Ignimbrite pillars at Lake Crowley (03482/41637). Thousands of closely spaced pillars (fig. 32) lightly indurated by a zeolite, mordenite, are developed in structureless ignimbrite of the earliest package (Ig1Ea) of the Bishop Tuff. The base is not exposed here but is thought to lie less than a few tens of meters below the beach level exposed. The area is well outside the structural caldera, and granodiorite is exposed beneath the Bishop Tuff in many places a few kilometers away. Thin intercalations of plinian fallout are common in Ig1Ea, and one is prominent near beach level in the area containing the pillars. Most pillars are vertical, $20-50 \mathrm{~cm}$ in diameter, and exposed for 3-8 $\mathrm{m}$ above the beach. Most are circular in cross-section, and none are polygonal. However, several sets of pillars are inclined, and tabular sheets (fig. 32) of similarly indurated material are developed locally. We observed no lithic-enriched degassing channels or lithic-concentration zones. Apart from the effective induration that stabilizes the pillars, there is little obvious contrast in composition, texture, or sorting between the pillars and the nonwelded tuff matrix that separates them; the pillars have not been elutriated by degassing. Most pillars are segmented by horizontal cracks spaced 5-40 cm apart. Zeolitization may have been promoted during cooling of the tuff by periodically spaced plumes of warm fluid rising slowly from marshy ground of the river valley buried by the ash flows. Similar pillars are exposed in Ig1E in nearby roadcuts at Highway 395 (03474/41598) and Lake Crowley Drive (03477/41586), but they are less well defined than those cleaned off by wave action at the lakeshore.

From Toms Place, go 2.2 miles west on Crowley Lake Drive and park at an isolated roadcut through nonwelded Bishop Tuff near the scattered settlement of Aspen Springs at the head of Little Round Valley. Alternatively, from Highway 395, take South Landing Road south to its T-junction with Crowley Lake Drive (03463/41584), then go 1.6 miles east (left), crossing a ridgecrest roadcut in nonwelded Bishop Tuff, descending into Little Round Valley, and parking at the isolated roadcut in the Bishop Tuff.

\section{Stop 21. Little Round Valley roadcut (03482/41578).}

Fringes of nonwelded ignimbrite survive on all sides of the 2,070-m meadow that today floors the nearly enclosed bowl. A ridge of Ig1 as high as 2,224 $\mathrm{m}$ borders the bowl on the north, 


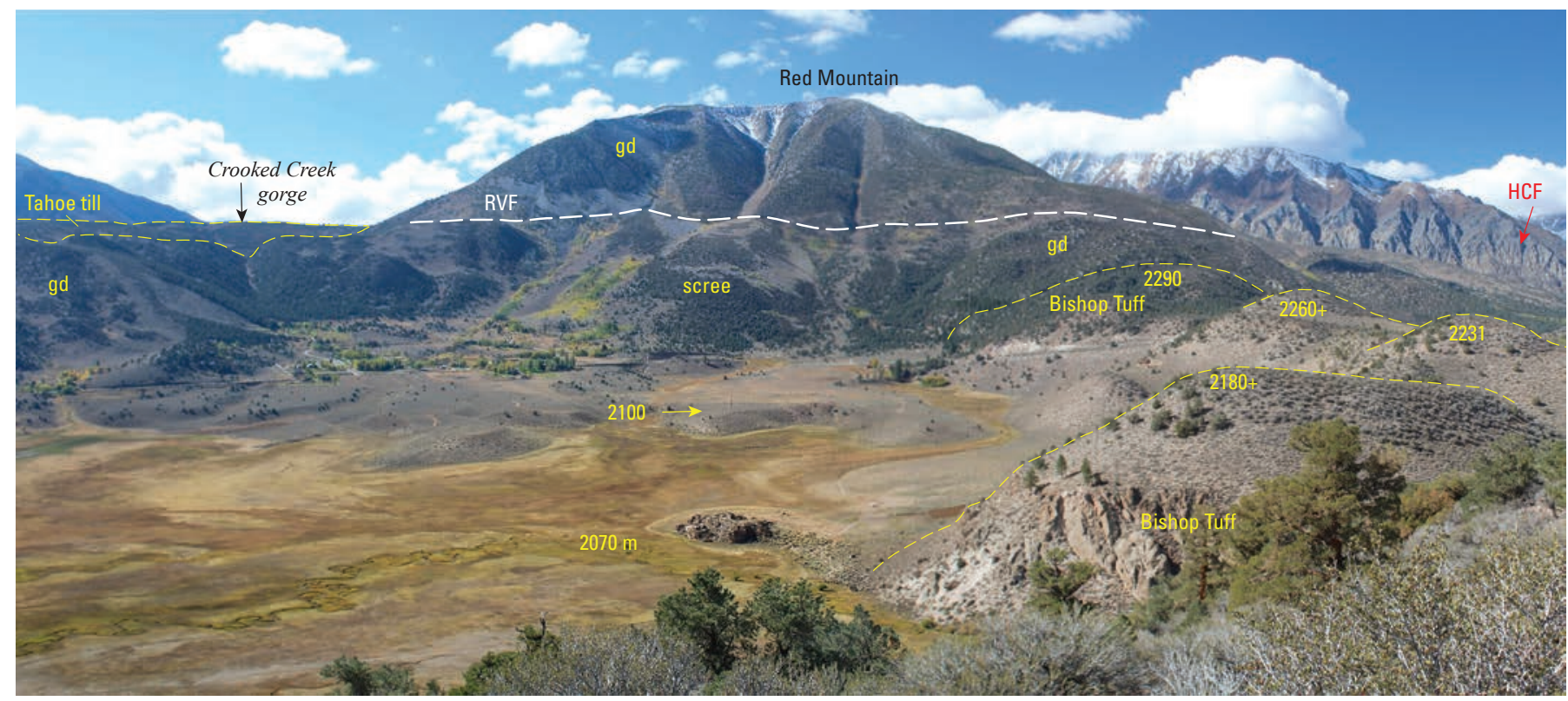

Figure 33. Little Round Valley viewed southward from crest of knoll 2224. Bishop Tuff fringes most of valley floor as low as 2,070 $\mathrm{m}$ above sea level, but at right it also forms four eroded knolls (outlined) that rise southward from $\sim 2,180 \mathrm{~m}$ to 2,290 $\mathrm{m}$, showing that more than $200 \mathrm{~m}$ of ignimbrite was eroded away in excavating Little Round Valley. Removal of as much as $1 \mathrm{~km}^{3}$ of ignimbrite was accomplished principally by Crooked Creek, which cut a granodiorite gorge at upper left and was a major distributary of Rock Creek until its permanent blockage by a Tahoe moraine during Marine Isotope Stage 6. At its highstand (but not before), Pleistocene Long Valley Lake then shallowly inundated Little Round Valley, producing a wave-planed terrace at $\sim 2,100 \mathrm{~m}$, atop nonwelded Bishop Tuff, that has subsequently been veneered by alluvium and colluvium. Before and after the lake's highstand, Crooked Creek drained from Little Round Valley to Long Valley via a gorge just below lower right edge of the image. Red Mountain and valley wall at left consist of Triassic Wheeler Crest Granodiorite of Scheelite Intrusive Suite (labelled gd; Bateman, 1992). In upper-right distance, triangular facets on Paleozoic metasedimentary rocks mark the north-striking Hilton Creek (normal) Fault (HCF). Three major ravines that descend face of Red Mountain have together deposited an enormous apron of granodioritic scree, and all three have been displaced dextrally $150 \mathrm{~m}$ by the oblique-slip Round Valley Fault (RVF). Little Round Valley was never glaciated. From Hildreth and Fierstein (2016b); photo by Fierstein in October 2015.

and the west wall of the bowl is a ridge of Bishop Tuff that rises southward from $\sim 2,180$ to $2,290 \mathrm{~m}, 220 \mathrm{~m}$ higher than the meadow. The ridge is mostly Ig1, but four knolls along its crest are capped by remnants of Ig2. If the tuff that filled $5-\mathrm{km}^{2}$ Little Round Valley had on average been $200 \mathrm{~m}$ thick, then $1 \mathrm{~km}^{3}$ is missing. Crooked Creek, which flows northward through a granodiorite gorge into uppermost Little Round Valley (fig. 33), is likely to have been the major agent of erosion. Its course was aligned with the main north-flowing reach of upper Rock Creek, a major Sierran canyon, from which it became separated only by emplacement of a large Tahoe (MIS 6) moraine (Rinehart and Ross, 1957). Before the Tahoe-age blockage, streams had more than half a million years to erode $200 \mathrm{~m}$ of Bishop Tuff out of Little Round Valley. The excavation took place before Long Valley's caldera lake filled deep enough to spill over into Little Round Valley. When it did so at the time of the lake's highstand ( $180 \mathrm{ka})$, the Little Round Valley embayment was confined to the floor of the bowl and no deeper than $\sim 30 \mathrm{~m}$. Its strandline at present-day elevation of $\sim 2,100 \mathrm{~m}$ reflects post-lake southward tilting by $\sim 50 \mathrm{~m}$ relative to the 2,150-m elevation of the highstand at the Owens River Gorge rim, only $3 \mathrm{~km}$ north. Had the lake embayment in Little Round Valley ever reached a pre-tilt level of 2,150 m, it would have overflowed eastward into Rock Creek, which it did not do. Were it not for the large alluvial fan constructed in the middle Pleistocene at Toms Place, Long Valley Lake could have drained to Rock Creek and postcaldera Owens Gorge need never have been reincised.

After withdrawal of the lake from Little Round Valley ( $\sim 150 \mathrm{ka})$, talus, alluvium, and avalanche tongues of angular granite blocks have covered much of the southern fringe of Bishop Tuff and locally encroached beyond it onto the meadow floor. The granitic debris is the lower end (at 2,100 m) of an enormous talus apron that spans the entire south slope of Little Round Valley (fig. 33) and extends up the Sierran front to as high as 2,800 $\mathrm{m}$ (Rinehart and Ross, 1957). The roadcut at hand displays incorporation of some of the overrun talus by the nonwelded base of the ignimbrite and later scour of the ignimbrite surface by avalanche sheets from higher parts of the talus apron (fig. 34). Others have speculated that features in this exposure reflect emplacement of the Bishop Tuff atop a glacier postulated to have occupied Little Round Valley at the time of the eruption, but abundant evidence compels rejection of the suggestion. Nonwelded Bishop Tuff survives as fringes around 


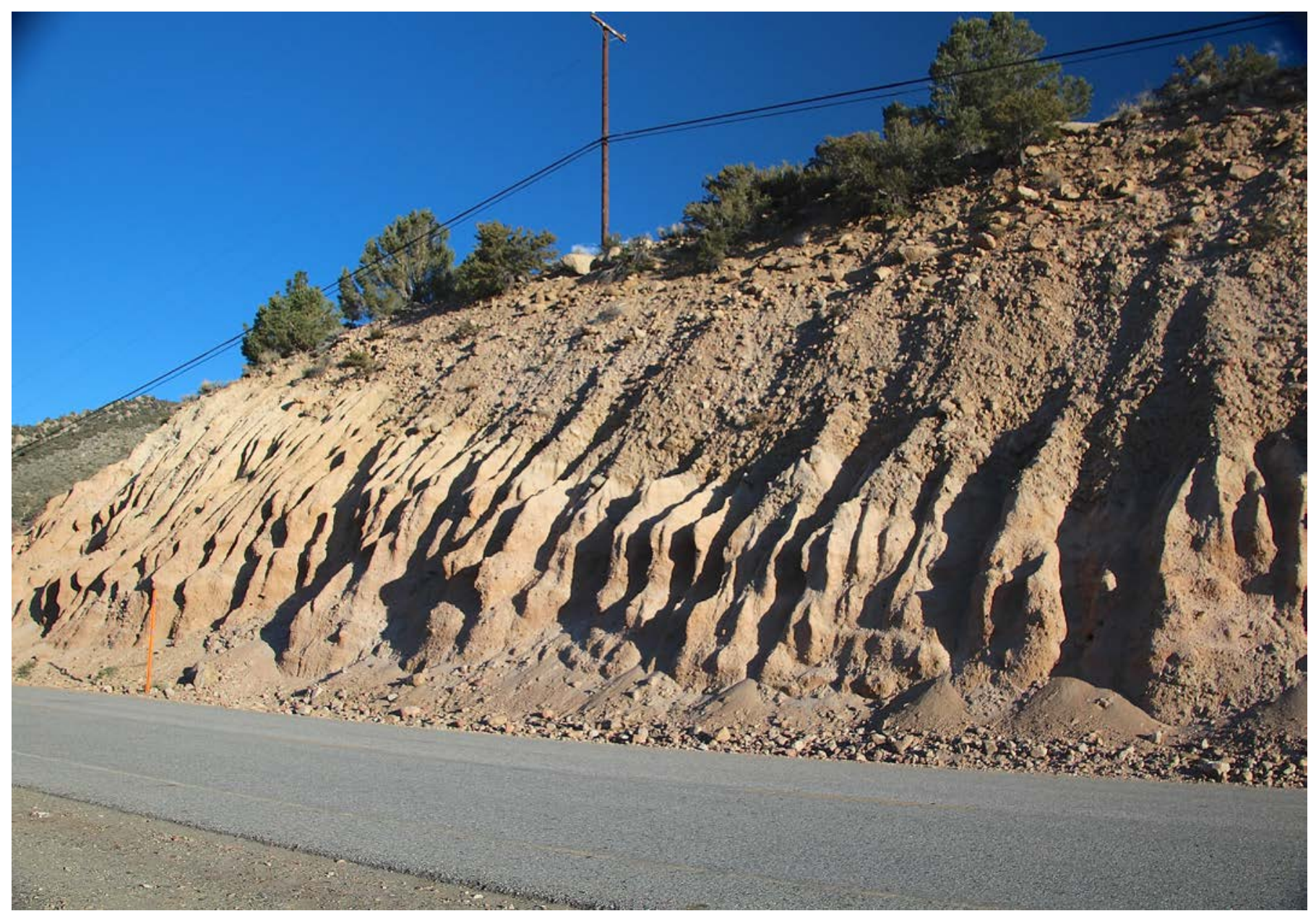

Figure 34. Photo showing nonwelded Bishop Tuff roadcut in Little Round Valley. Ignimbrite ran up slope of granitic scree on face of Red Mountain (fig. 33), incorporating distributed clusters of angular granitic clasts. Much later, after most Bishop Tuff had been removed from Little Round Valley, an avalanche of the same scree scoured a broad swale across the secularly eroded surface of the ignimbrite deposit, which is still at least $150 \mathrm{~m}$ thick on the nearby valley wall. The poorly sorted avalanche deposit is $5-8 \mathrm{~m}$ thick and overlain by a few meters of coarser granitic colluvium.

much of the meadow floor, and moraines are not present anywhere within the nearly closed bowl. There are fluid-indurated pipes in nonwelded tuff in the roadcuts but no pervasive vapor-phase alteration. There is no till at all but, instead, an enormous talus slope that drapes the Sierran granitic wall for $>700 \mathrm{~m}$ above the floor of Little Round Valley, showing that there had been no glaciation here, at least since the precaldera Sherwin glaciation (MIS 22).

\section{End of Day 2}

\section{Day 3. Caldera Day}

\section{Stop 22. Geothermal plant at site of Casa Diablo Hot}

Springs. From the cloverleaf intersection of Highways 203 and 395, drive 200 m east of the overpass and turn left on a poorly paved road. Proceed 0.4 mile, bypassing the plant entrance, and turning right onto a dirt road that ascends a rhyolite hill (03308/41681) that provides a panorama of the geothermal facility.

Casa Diablo Hot Springs was long used by Native Americans and pioneers, and it was a stagecoach station from 1878 to 1881 . Tourism took over by the 1920 s, and it was variously the site of a trading post, spa, tavern, gas station, hardware store, and lumber yard until 1983, when geothermal development began. The north-trending fault just east of the plant is a major component of the graben that cuts early postcaldera rhyolite of the resurgent uplift; the white zone of hydrothermal alteration along the fault was prospected for kaolinite. Boiling springs, fumaroles, and mudpots were numerous at the site of the plant, and geysers as high as $20 \mathrm{~m}$ were reported in 1937 and 1959. Geothermal exploration wells were drilled as early as 1959, but a power plant first began operation in 1984 . Stepwise expansion has provided capacity for 40 megawatts of electricity from three generating units. Production wells tap $170{ }^{\circ} \mathrm{C}$ water from an aquifer at a depth of 135-200 m in permeable early rhyolite that overlies the Bishop Tuff. Aquifer flow is laterally eastward from beneath the caldera's 
west moat, where drilling encountered temperatures as high as $218^{\circ} \mathrm{C}$ (Suemnicht, 1987; Suemnicht and others, 2006; Sorey and others, 1991). Natural discharge is largely at Hot Creek 7-8 km east of the plant and at numerous springs farther east in the Long Valley lowland.

A binary closed-loop generating system employs heat exchangers in which the heat of the geothermal fluid is transferred to a lower-boiling-point fluid (isobutane), which is thereby vaporized and drives turbine generators. A hybrid air-water cooling system re-liquifies the isobutane, which is collected and recirculated through the heat exchanger. The geothermal water is reinjected into the Bishop Tuff at depths greater than $600 \mathrm{~m}$, far beneath the hot-water aquifer. In principle, there is thus no net withdrawal of geothermal water, but the USGS hydrologic program monitors water chemistry and discharge at springs downstream and in several wells. The power is sold to Southern California Edison, which operates a substation concealed in the woods just north of the plant.

The knoll on which we stopped provides good examples of varied textures and flow foliation in the early postcaldera rhyolite (750-640 ka) that forms much of the resurgent uplift. Down the road, just south of the entrance gate to the geothermal plant, patches of bare ground are warm to the touch.

From stoplight at Shell gas station at junction of Old Mammoth Road and Highway 203, go 150 m east on Highway 203 (Main Street) and turn left on Sawmill Cutoff. Where pavement ends after 0.7 mile, continue straight on bumpy dirt road, ignoring paved right turn toward Shady Rest Park. After 2.0 additional miles, at the hilltop high point of Sawmill Cutoff, turn left onto road 3S33. This road ascends a poorly exposed basaltic unit (48.5 percent $\mathrm{SiO}_{2} ; 165 \mathrm{ka}$ ), but at a cross road after 0.7 mile it ascends more steeply straight ahead onto the extensive West Moat Coulee (73 percent $\mathrm{SiO}_{2} ; 150 \mathrm{ka}$ ). After an additional 0.7 mile, keep right on road $3 S 33$ at a four-way intersection with road 3S48. After 0.2 mile farther, stay straight ahead onto road 3 S34 at a fork where road $3 S 33$ swings right and is signed toward the Scenic Loop. In 0.5 mile, road $3 S 34$ bends left through a roadcut (032563/41717) in the ejecta ring of the West Moat Coulee. After 0.2 mile more, at the high point on the main road, turn steeply left on road $3 S 34 B$ and park in line atop the ejectaring ridge at a fine viewpoint (032585/41699). There will be no need to turn around.

Stop 23. Ejecta ring of the West Moat Coulee $\mathbf{( 0 3 2 5 8 5 / 4 1 6 9 9 )}$. The coulee is the oldest (150 ka) and most voluminous of the west moat rhyolites. The others, Deer Mountain, Dry Creek dome, and Mammoth Knolls dome, all erupted $\sim 115-100 \mathrm{ka}$. The half-ring of ejecta crossed by the road here is the source of the coulee, but part of the ring was destroyed by extrusion of the adjacent Mammoth Knolls dome. As neither unit was glaciated, they remain cloaked in finely vesicular glassy carapace, though the knobby rolling surface of the older coulee does expose patches of dense felsite. The coulee, in common with Deer Mountain dome, has 72-73 percent $\mathrm{SiO}_{2}$ and 2.1 percent $\mathrm{FeO}^{*}$, in contrast to the Mammoth Knolls and Dry Creek domes, which have 76.5 percent $\mathrm{SiO}_{2}$ and 0.9 percent $\mathrm{FeO} *$. The coulee and domes all contain quartz and biotite, so the best field distinction here is the greater size and abundance of hornblende and feldspar in the coulee. The coulee is $5 \mathrm{~km}$ long, $1.5-2.5 \mathrm{~km}$ wide, and has margins 50-80 m high, whereas the bilobate Mammoth Knolls dome is 1.5 by $0.8 \mathrm{~km}$ wide and has $\sim 200 \mathrm{~m}$ of steep-sided relief. The 50-m-high half-ring of ejecta is $500-800 \mathrm{~m}$ across but only $300 \mathrm{~m}$ wide along its rim. Among the ejecta are dense cognate rhyolite blocks (both vitrophyric and flow-foliated felsite) and fragments of mafic lavas that we correlate with adjacent and subjacent units with ages of 150-190 ka (Hildreth and Fierstein, 2016a). The ring is also lightly sprinkled with pumice from the younger Mammoth Knolls dome.

The hilltop stop provides fine views from the Sierra Nevada to Glass Mountain and the White Mountains, including the caldera (and its walls, resurgent uplift, and south moat), Mammoth Mountain, and numerous moraine loops east of town.

Without turning around, this side road permits an anticlockwise loop back onto the entry road 3S34. On completing the circle, drive 0.1 mile downhill (south) and turn right on road $3 S 34 C$. After an additional 0.1 mile, bear left on $3 S 34 D$, which ends in another 0.1 mile at a geophysical monitoring station (03254/41699) with carpark, room to turn around, and good exposures of Mammoth Knolls rhyolite lava.

Stop 24. Vista point at summit of Mammoth Knolls. The steep-sided bilobate dome rises $200 \mathrm{~m}$ above the business district of Mammoth Lakes. Exposures are nonglaciated, glassy, finely vesicular to micropumiceous, and white to pale gray, weathering tan. The 76.5 percent $\mathrm{SiO}_{2}$ rhyolite contains $\sim 15$ percent feldspar phenocrysts (more sanidine than plagioclase); 2-3 percent quartz (many embayed), 1-2 percent biotite, sparse hornblende, and trace amounts of Fe-Ti oxides, zircon, apatite, and allanite. Both lobes gave ${ }^{40} \mathrm{Ar} /{ }^{39} \mathrm{Ar}$ ages of $\sim 110 \mathrm{ka}$. The rolling knobby surface of the dome affords fine views of Mammoth Mountain, the MIS 2 moraine belt, preCenozoic Sierran rocks of the Mount Morrison pendant on the steep south wall of the caldera, and Mammoth Rock in all its marmoreal splendor.

Return the way you came to Sawmill Cutoff, Highway 203, and downtown Mammoth Lakes. Consider an hour-long side trip to Stop 31 (early rhyolite obsidian of Sawmill dome) when you return to Sawmill Cutoff.

Stop 25. Casa Diablo Till via Sawmill Road. Drive eastward downhill on Highway 203 almost to Highway 395, but turn left on Sawmill Road $(033065 / 416745) \sim 0.25$ mile before the overpass. On ascending $\sim 0.4$ mile on Sawmill Road, a dirt road to the left leads to a concrete barrier across an arroyo (03300/41676); this provides access across the draw to the metavolcanic-dominant right-lateral moraine described below. The granite-dominant left-lateral is best seen by driving an 
additional 1.4 miles west up Sawmill Road and walking $\sim 150$ m north from a geothermal well $(032835 / 416905)$ to a low morainal ridge (03284/41691).

Before growth of Mammoth Mountain (100-50 ka), ice from the Lakes Basin and Sierran crest had advanced $\sim 1.5 \mathrm{~km}$ farther east than the distal Tioga (MIS 2) moraines along Mammoth Creek, depositing poorly preserved moraines called "Casa Diablo Till” by Curry (1968). Kesseli (1941) and Curry (1968, 1971) recognized that mafic lava flows separate the tills and that the older deposit lacks clasts from Mammoth Mountain. A phenocryst-poor lava flow that underlies the older till has now been precisely dated at $162 \pm 2 \mathrm{ka}$, and a phenocryst-rich flow that overlies it yielded an age of $125 \pm 2 \mathrm{ka}$, confirming that the till represents MIS 6 (Mahood and others, 2010; Hildreth and others, 2014). Boulders in the till correlate with six different mafic lavas dated between $175 \mathrm{ka}$ and $153 \mathrm{ka}$. Former speculations on older ages for the Casa Diablo Till were based on K-Ar ages, far too old, for xenocryst-bearing mafic lavas and for Mammoth Mountain biotite that contains excess Ar (Mahood and others, 2010). The till was thus deposited during the glaciation responsible for Sierran moraines elsewhere called Tahoe till.

Casa Diablo Till crops out in two swaths separated by younger lava flows. The northerly one extends for $3 \mathrm{~km}$ along and north of Sawmill Road and includes a low moraine crest; boulder counts yield 80 percent granitoids, 9 percent metavolcanics, and 11 percent mafic lavas. The southeasterly swath extends $1.2 \mathrm{~km}$ across Highway 203 and Mammoth Creek and is eroded and topographically irregular; counts of its boulders at two sites gave 5-27 percent granitoids, 56-85 percent metavolcanics, and 10-17 percent mafic lavas. The left-lateral moraine carried debris mostly from Lakes Basin, while the right-lateral debris came predominantly from Cold Water Canyon and Red Mountain (seen from Stop 3). Similar lithologic asymmetry characterizes the Tioga (MIS 2) moraines on opposite sides of the Mammoth Creek corridor down which the ice repeatedly advanced.

From the cloverleaf intersection of Highways 203 and 395, drive 7.3 miles north to a right turn onto paved Owens River Road. (At 6.2 miles, Highway 395 ascends the east slope of an extensive 66-ka basaltic flow field; at 7.0 miles, a roadside rest area with toilets is on the left). Heading east on Owens River Road, good views of the caldera's north wall on the left include a forested basaltic cone and a barren trachydacite dome, both $\sim 3.4 \mathrm{Ma}$, atop lower scarps of Mesozoic granodiorite. At 2.0 miles, there is a left turn for Big Springs campground and Alpers Canyon, and at 3.7 miles the pavement ends just beyond entrances to Arcularius Ranch. After a total of 4.4 miles on Owens River Road, turn right on dirt road 2 S36 and follow it south for 1.0 mile to a T-junction with road 2S90, where you turn right (west). Go 0.2 mile west (ignoring road $2 S 91$ on the left) and park at the mouth of Dry Creek gorge where road $2 S 90$ swings right and a road into the gorge is fenced off. Walk $\sim 250 \mathrm{~m}$ south into the gorge and scramble $\sim 30 \mathrm{~m}$ up the east wall (on your left) to a rim-forming ledge.
Stop 26. Moat rhyolite and early rhyolite at Dry Creek gorge. The ledge is the base of a phenocryst-rich rhyolite coulee that contains sanidine, plagioclase, biotite, hornblende, Fe-Ti oxides, and sparse rounded quartz. The slope beneath it is aphyric early rhyolite, some of it obsidian, as is the entire west (left-bank) wall of the gorge. The aphyric rhyolite incised by the gorge is a coulee that flowed $2 \mathrm{~km}$ east from the Lookout Mountain edifice and here yielded a K-Ar age of $692 \pm 14 \mathrm{ka}$ (Mankinen and others, 1986). The crystal-rich rhyolite above it gave $\mathrm{a}^{40} \mathrm{Ar} /{ }^{39} \mathrm{Ar}$ age of $570 \pm 8 \mathrm{ka}$ (Simon and others, 2014) and is the largest component of the north-central rhyolite chain (Hildreth, 2004). The $3-\mathrm{km}^{2}$ coulee ( 74.3 percent $\mathrm{SiO}_{2}$ ) extends $2 \mathrm{~km}$ west from Dome 2415 (its vent site), then 4 km northeastward, descending the north slope of the caldera's resurgent uplift into its north moat. The slope shows that most of the resurgent uplift had taken place by $570 \mathrm{ka}$. Maximum relief exposed on the coulee is $\sim 60 \mathrm{~m}$ just west of the dome and $\sim 40 \mathrm{~m}$ here. Like other Long Valley rhyolites, the coulee is subalkaline, contrasting with the mildly alkaline trachydacite domes of Mammoth Mountain (fig. 14).

The lower $10 \mathrm{~m}$ of the coulee exposed here at Dry Creek is coarse lava-flow breccia (not agglutinated spatter as interpreted by Bailey, 1989). Milled during flow, the rhyolite blocks are angular to subrounded, commonly $10-50 \mathrm{~cm}$ across, and as big as $1 \mathrm{~m}$. Blocks are separated by crush breccia of smaller angular clasts, which are generally weakly to moderately adherent but locally strongly healed to ghost-breccia texture. Mafic enclaves (53.3-54.7 percent $\mathrm{SiO}_{2}$ ) are abundant within the rhyolite blocks, in interblock breccia, and widely throughout the coulee, whether locally brecciated or massive. The enclaves are angular to rounded, 1-25 cm across, and contain sparse plagioclase and olivine crystals.

\section{Turn around and retrace the route to Owens River Road.}

\section{Stop 27. North moat basalt from Minaret Summit scoria} cone.

Turn right (east) on Owens River Road, drive 1.2 miles east, and pull off where a pair of basaltic lava flows are close to the road on your left (03348/41789).

These phenocryst-rich trachybasalts are part of a package that flowed $\sim 23 \mathrm{~km}$ from the scoria cone (figs. $10,17)$ on the caldera's west wall just northeast of Minaret Summit. They are exposed discontinuously beneath till and younger lavas along the west moat, but they re-emerge at Big Springs and then parallel the Owens River for $10 \mathrm{~km}$ to a terminus at Inaja Ranch, $4 \mathrm{~km}$ east of here. Each flow here is 5-6 m thick, partly massive but mostly vesicular, locally jointed prismatically, and ruggedly scoriaceous everywhere outside the glacial limit (which is in the west moat). Plagioclase and olivine are abundant, while clinopyroxene is sparse and even sparser distally. Six sites - proximal, medial, and distal (here) - yield the same paleomagnetic direction (Hildreth and others, 2014). Seventeen samples 
range from 50.9 to 51.2 percent $\mathrm{SiO}_{2}$, from 5.1 to 5.8 percent $\mathrm{MgO}$, and from 1.53 to 1.75 percent $\mathrm{K}_{2} \mathrm{O}$. Like the 18 -km-long basalt that flowed down the south moat from Mammoth Crest to Hot Creek, this set of flows illustrates how the caldera's resurgent uplift confined and directed fluid lavas to long narrow paths along the moats.

Reset odometer and continue east on Owens River Road. A rhyolite knob on the right after 0.3 mile is the terminus of the 570-ka enclave-bearing coulee seen at Stop 26 but buried medially by Pleistocene alluvium along the moat. A minor dirt road on the right at 0.7 mile leads to a quarry in the Pleistocene alluvium. A gate on the left at 2.6 miles leads to Inaja Ranch. Pass under a powerline at 3.7 miles and turn left 0.2 mile farther south onto a dirt road along a fenceline through sagebrush. Drive 1.0 miles east to a corral beside a meadow; open and close an unlocked gate on the left, and go 0.2 mile to a carpark at the end of the road. Walk $200 \mathrm{~m}$ north along a streamside path at the foot of a bluff of white silt.

\section{Stop 28. Tephras intercalated in lake silt at Owens River} bluff (03414/41769). Pleistocene Long Valley Lake (fig. 35 ) occupied the east half of the caldera for $\sim 600,000$ years before draining through Owens River Gorge soon after $150 \mathrm{ka}$. Drilling shows the lake sediments that overlie the intracaldera Bishop Tuff to be at least $700 \mathrm{~m}$ thick. Pebbly sandstone and loose shingle form peripheral littoral facies, whereas fine sand, silt, and clay, rich in rhyolitic ash, ostracods, and diatoms, form the central facies. The 16-m-high cutbank here may contain the stratigraphically highest, youngest, and apparently terminal outcrop of the central facies (fig. 36). The lower $6 \mathrm{~m}$ of white silt grades up into a $2.5-\mathrm{m}$ sand-richer shoreface interval with reworked lenses of early rhyolite pumice. The top $7.5 \mathrm{~m}$ of the section is fluvio-lacustrine sandy pebble gravel. The silt section exposes 12 thin ash layers, some of which were probably reworked. Most of the 11 ash layers we collected in the bluff silt section are rhyolitic, contain biotite and hornblende, and are well correlated by microprobe mineral analyses (fig. 37) with the 150-ka West Moat Coulee, the vent for which is marked by a pumice-rich ejecta ring (Stop 23) $17 \mathrm{~km}$ west of here. The microprobe data exclude correlation with all of the many other postcaldera Long Valley rhyolites (fig. 7) and with the eruptive products of Mammoth Mountain. The lacustrine tephra here thus indicates that silt deposition along the lake axis persisted until a time only slightly younger than the 150-ka ashfalls.

Across the Owens River meadows, $3 \mathrm{~km}$ north-northeast, a rhyodacite lava dome $110 \mathrm{~m}$ high rises above the alluvial fan at the base of the caldera wall. The undated dome rises steeply from its base at $\sim 2,145 \mathrm{~m}$ asl to its summit at 2,256 m (7,403 ft), and it shows no evidence of lake action. Its surface is everywhere glassy and mostly finely pumiceous, and it exhibits no tufa, erratics, shoreline shingle, or wave-rounding of its fringing talus, despite highstand gravels as high as $2,265 \mathrm{~m}$ asl on the two granitic spurs that flank the dome at the caldera wall $<1 \mathrm{~km}$ away.

The lower part of the caldera's north wall, as seen from here, is mostly granitic, overlain by forested Glass Mountain rhyolite to the east and a sagebrush plateau of Pliocene basalts to the west. Highstand shoreline features are preserved locally on the granite, but for $9 \mathrm{~km}$ southeast along the base of Glass Mountain they are obliterated by rhyolite-dominant post-lake alluvial fans.

Reset odometers and continue south on Owens River Road. Ignore right turns for Little Hot Creek after 2.0 miles and for Antelope Springs Road after 3.1 miles. About 0.6 mile farther (after a total of 3.7 miles), turn right just before a bridge and park right away alongside Hot Creek.

Figure 35. Map showing shoreline features and deposits of Pleistocene Long Valley Lake. Elevation 2,250 and 2,500 m contours indicate lower part of caldera wall, delimiting caldera floor. Area underlain by siltstone facies (st, central part of ancient lake), shown in yellowish tan, is actually exposed discontinuously, widely veneered by post-lake alluvium. Shown in green is present-day outcrop of littoral facies (ss) - pebble conglomerate and sandstone. Both facies are in some places overlain by alluvial fans that have encroached from north, east, and southwest since draining of the lake. Lake Crowley reservoir, dammed in 1941, is unrelated to the Pleistocene lake but shares its outlet. Red line segments with elevations are mapped remnants of highstand shoreline (sh), mostly wave-rounded pebbles and shingle. Dotted circle $10 \mathrm{~km}$ in diameter encloses postcaldera resurgent uplift, which lifted intracaldera early rhyolites $>400 \mathrm{~m}$ and mildly tilted sandstones deposited against its eastern slope; elevations (in meters above sea level) of sandstone contacts are indicated. Hot Creek flow is rhyolite coulee that flowed north into lake at $333 \mathrm{ka}$. Three smaller rhyolite lavas east of Hot Creek flow, all sediment-mantled, are likewise colored pink. Isolated patches of indurated sandstone (ss), loose shoreline gravel (sh), and tufa (t) are indicated by dots colored as in map explanation. Gray dots mark clusters of erratics (many larger than 1 $\mathrm{m}$ ) ice-rafted across the Pleistocene lake from Sierran glaciers. Well $\mathrm{OH}-1$ in town of Mammoth Lakes penetrated lake sediments at elevations 2,078-2,135 m above sea level. Wells $\mathrm{CH}-1$ and 66-29, near center of diagram, penetrate ash-rich lake sediments 305 $\mathrm{m}$ and $700 \mathrm{~m}$ thick, respectively. Dash-dot gray line traces eastern drainage divide separating Long Valley from Owens Valley that was breached when Long Valley Lake overflowed its threshold and cut modern Owens River Gorge. Saddles 2293 and 2297 on the divide remained slightly higher than highstand of lake, which never overflowed eastward toward Chidago Canyon. Abbreviations: AR, Arcularius Ranch; BC, Benton Crossing bridge; CBR, Cashbaugh Ranch; CR, Chance Ranch; CV, Crestview; EP, East Portal of Mono Craters tunnel; FV, Fumarole Valley; GP, geothermal plant at site of former Casa Diablo Hot Springs; HC, Hilton Creek; IR, Inaja Ranch; LAV, Little Antelope Valley; LHC, Little Hot Creek; LRV, Little Round Valley; hachures outline bowl eroded in Bishop Tuff; LS, Layton Springs; MC, McGee Creek; ML, downtown Mammoth Lakes; PH-1, power house \#1; SL, South Landing; TP, Toms Place; WC, Whisky Creek. For shaft 2, see figure 2. Tunnel \#1 brings reservoir water to power house \#1 of Los Angeles Department of Water and Power. 


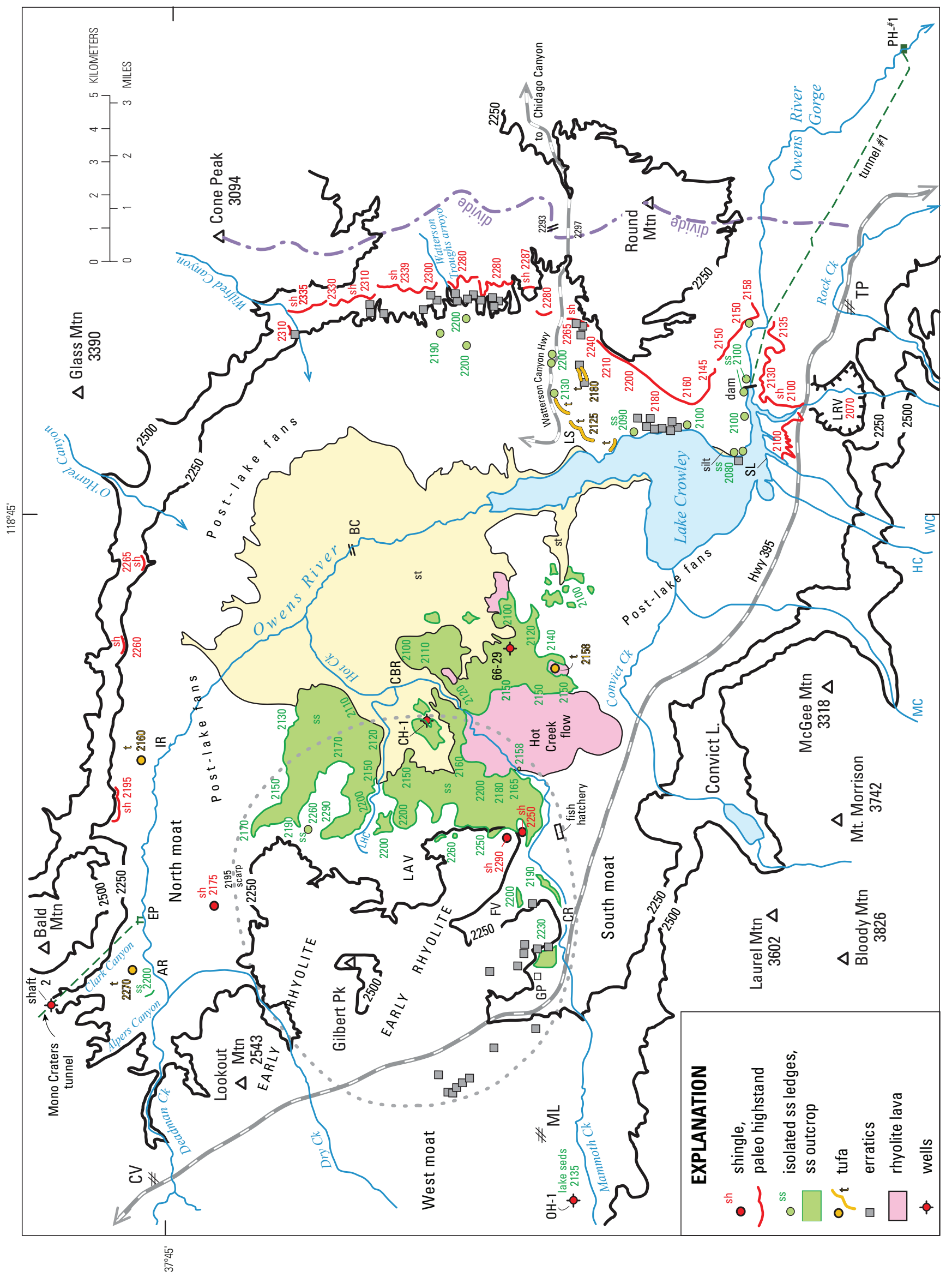




\section{Stop 29. Deltaic sandstone at Hot Creek bridge}

(03406/417115). Scarps $\sim 10 \mathrm{~m}$ high on both sides of the creek consist of fine, medium, and coarse grained sandstone, laminated to thin bedded and silica-cemented, that splits platy to flaggy. The sandstone is part of the littoral facies of Pleistocene Long Valley Lake and is here deltaic where ancestral Hot Creek debouched into the lake. The sandy subhorizontal topsets were probably not far below water level, and the foresets that dip $15-20^{\circ} \mathrm{NE}$. have amplitudes of $\sim 7 \mathrm{~m}$, providing an estimate of minimum water depth at the site of deposition. Hot Creek is a segment of Mammoth Creek, which heads in the Sierra, so the sand consists of granite-derived quartz as well as material locally derived from rhyolite. Most sandstone on the east side of the Pleistocene lake is carbonate cemented, but here on the west side most of it is silica cemented, reflecting a long history of thermal springs and rhyolitic volcanism. Much of the sandstone on both sides of the Pleistocene lake is pebbly, but here the deltaic contribution of ancestral Hot Creek was better sorted, the gravel load having been dropped farther west. The rim of the sandstone plateau here is at an elevation of $2,120 \mathrm{~m}$. The plateau rises gently $\left(\sim 1^{\circ}\right)$ for $1.7 \mathrm{~km}$ southwest to where the sandstone banks against the 333-ka Hot Creek rhyolite coulee at $2,150 \mathrm{~m}$. The extensive sandstone plateau is little eroded and may be among the youngest parts of the littoral facies preserved along the west side of the basin. The prograded sandstone sheet thins and terminates over the central siltstone facies just north and east of here.

Cross the Hot Creek bridge and in 0.1 mile turn right on Whitmore Tubs Road. After 0.6 miles turn right on Hot Creek Hatchery Road. In another 0.6 mile, the road passes from the sandstone plateau onto the 333-ka Hot Creek rhyolite coulee. After another 0.5 mile, stop at a carpark with toilets and a trailhead into the gorge. Prepare for an easy hour-long walk along the gorge floor.

Stop 30. Hot Creek geothermal area $(\mathbf{0 3 3 8 9} / \mathbf{4 1 6 9 6 )}$. The phenocryst-poor Hot Creek flow (76.0-76.2 percent $\mathrm{SiO}_{2}$ ), as wide as $2.5 \mathrm{~km}$ and $5 \mathrm{~km}$ long in the south moat of Long Valley Caldera, erupted at a subaerial vent and flowed northward where much of it invaded Pleistocene Long Valley Lake, producing widespread flow breccia and perlite. As the lake receded between 180 and $150 \mathrm{ka}$, the gorge was cut through

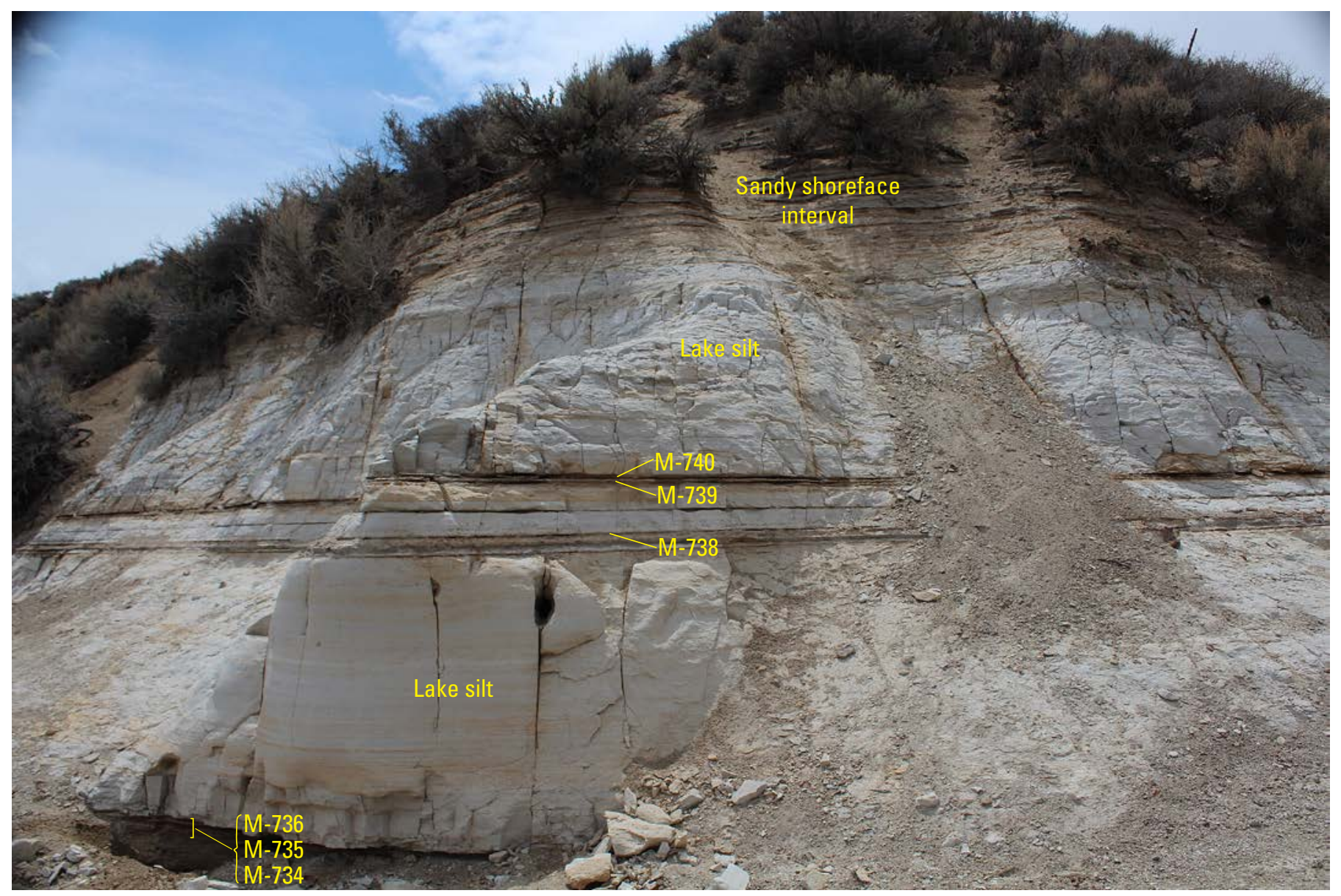

Figure 36. Photo of Owens River Bluff sedimentary section (UTM 03415/41769): ash layers interbedded at top of lacustrine silt deposit, more than 700 m thick, which is central facies of Pleistocene Long Valley Lake. Exposed 6-m white silt section grades up into 2.5-m sandy shoreface interval, overlain by $7.5 \mathrm{~m}$ of fluviolacustrine sandy pebble gravel. Locations of samples M-734 through M-740 are shown here; see figure 37 for stratigraphic log and microprobe data that correlate most of these tephras with the 150-ka West Moat Coulee, $17 \mathrm{~km}$ southwest of the bluff. 

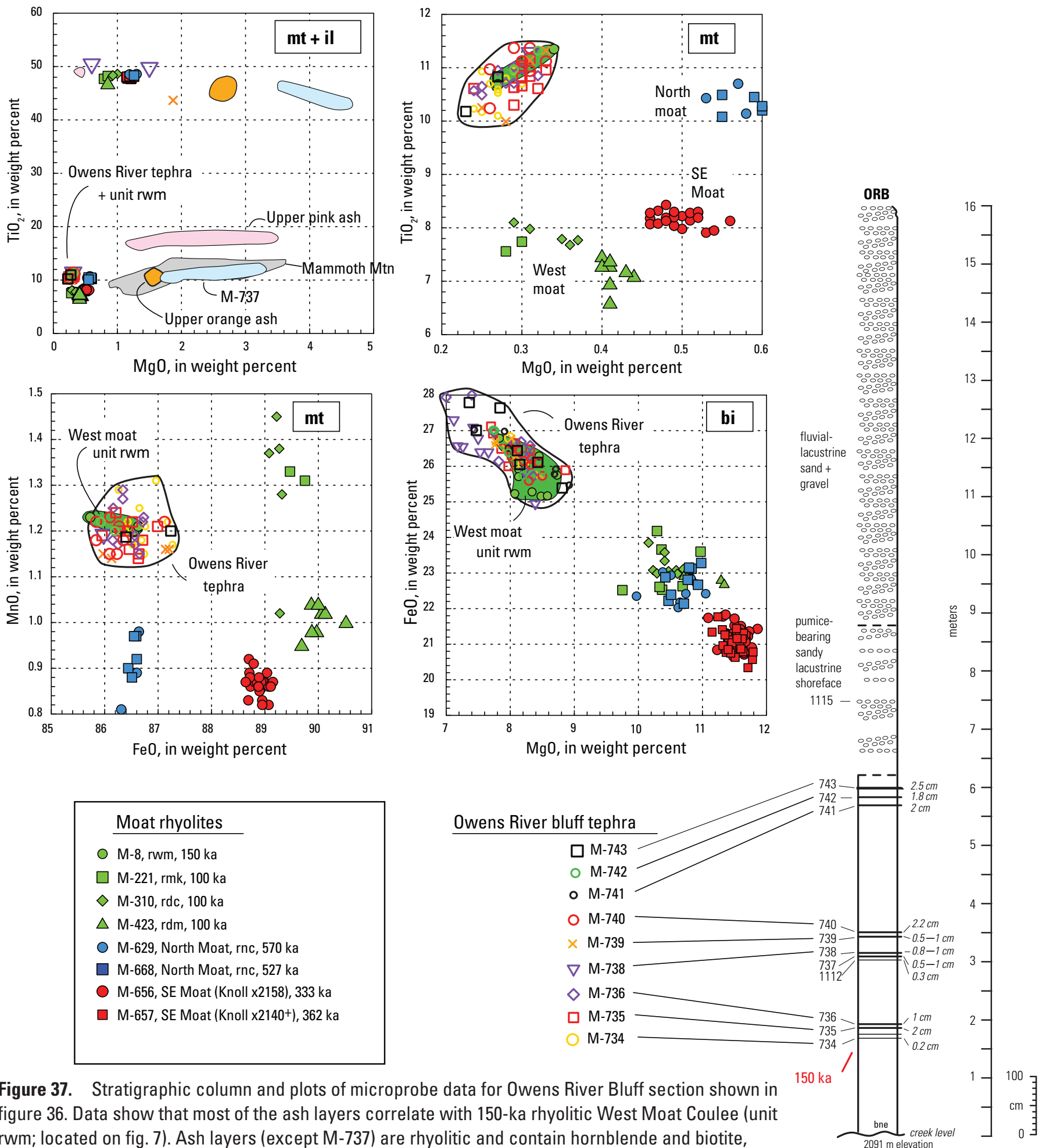

Figure 37. Stratigraphic column and plots of microprobe data for Owens River Bluff section shown in figure 36. Data show that most of the ash layers correlate with 150-ka rhyolitic West Moat Coulee (unit rwm; located on fig. 7). Ash layers (except M-737) are rhyolitic and contain hornblende and biotite, unlike the numerous mafic ash layers that predominate in Long Valley Lake silt exposures elsewhere (Hildreth and Fierstein, 2016b). Data plotted for magnetite (mt), ilmenite (il), and biotite (bi) exclude OWENS RIVER BLUFF correlation of these ashes with all other postcaldera rhyolites in north, southeast, and west moats of Long Valley Caldera (fig. 7) and with hornblende-biotite trachydacite products of Mammoth Mountain. Labels rmk, rdc, and rdm represent west-moat rhyolites of Mammoth Knolls, Dry Creek Dome, and Deer Mountain (fig. 7), which are described in detail by Hildreth and Fierstein (2016a). Tephras labelled "upper orange" and "upper pink" are orthopyroxene-bearing ash layers ( 211 ka) exposed in lake silts near Benton Crossing ( $\sim 5 \mathrm{~km}$ southeast of here; labeled BC on fig. 35), of probable Cascadian origin, as is layer M-737 (Hildreth and Fierstein, 2016b). 
the flow in response to dropping base level. The steep-sided coulee has $100 \mathrm{~m}$ of relief proximally, and its upper surface is hilly and craggy, but distal exposures have low relief and are partly lapped by younger lake sediments. Lithologically, the rhyolite is flow-foliated, locally vuggy, and variously includes pale-gray to black vitrophyre, bluish-gray resinous perlite, gray to pink felsite, coarsely pumiceous carapace, dark brown spherulitic zones, and flow breccia. Cream-white domains can be either felsite, finely vesicular glass, or silicified. Strongly oxidized and hydrothermally altered exposures are common along the gorge, which incises the coulee to a depth of $35 \mathrm{~m}$ and remains the present-day site of boiling pools, geysers, and fumaroles. Travertine terraces line creek banks in the thermal areas. The rhyolite contains only $\sim 1$ percent phenocrysts, of which half are plagioclase, accompanied by trace amounts of sanidine, biotite, and clinopyroxene, as well as microphenocrysts of Fe-Ti oxides, zircon, and apatite. The base is not exposed, but a drillhole entered lake sediments beneath the north-distal part of the flow at a depth of $60 \mathrm{~m}$.

Hot Creek is a segment of Mammoth Creek, which heads in the Sierra and remains cold and dilute for most of its course. Warm springs begin $\sim 4 \mathrm{~km}$ upstream of here near the fish hatchery, and many more discharge in the Long Valley lowlands north and east of here. The hottest springs and pools, boiling at $93{ }^{\circ} \mathrm{C}$, occur along this reach of the gorge, discharging from fractures in the rhyolite and releasing an estimated 240 liters per second of hot water, which is enriched in $\mathrm{NaHCO}_{3}, \mathrm{As}, \mathrm{B}$, and F. Fumaroles and the gases from bubbling pools are steam-dominated but rich in $\mathrm{CO}_{2}$ and carry minor $\mathrm{H}_{2} \mathrm{~S}$. Nearly all the thermal water is transported in shallow aquifers from the caldera's west moat, rather than ascending from depth near here, as discussed at Stop 22. The vigor, location, and configuration of the hot springs have been observed to change abruptly, sometimes in response to local earthquakes. Boiling geysers spurting to heights of 1-3 m in $1973,1978,1980$, and again in 2006 ultimately prompted the land-management agency to close the thermal area to swimming.

After continuing 1.5 miles southwest from the geothermal area carpark, consider another stop in the Hot Creek flow near a sharp right turn (03375/41676) onto the paved Fish Hatchery Road, adjacent to the (private) "Hot Creek Fly Fishing Ranch." From the road junction, upright fins of steeply foliated rhyolite rich in spherulites and lithophysae can be reached in a short uphill walk.

Follow the paved road past the fish hatchery to Highway 395 and return to Convict Lake or your alternative lodgings.

\section{End of Day 3}

\section{Day 4. Highlights}

From stoplight at Shell gas station at junction of Old Mammoth Road in downtown Mammoth Lakes, go 150 m east on
Highway 203 (Main Street) and turn left on Sawmill Cutoff (road 3S08). Where pavement ends after 0.7 mile, continue straight on bumpy dirt road, ignoring paved right turn toward Shady Rest Park. After 1.6 additional miles, turn right on road 3S37. Four-wheel drive is recommended but probably not necessary for this bumpy, rutted road. After 0.2 mile, bear sharp right, remaining on road $3 S 37$ (not straight on 3S37A). After 1.0 mile farther, turn left uphill on road 3S124. At a fork after another 0.5 mile, go sharply right and then wind around for an additional 0.3 mile to the summit of the obsidian dome (03292/41696). [If time and interest permit, this stop could conveniently be undertaken right after descending from Stop 24. From the junction of road $3 S 33$ with Sawmill Cutoff (3S08), side road $3 S 37$ (as just described) is only 0.4 mile downhill to the south.]

\section{Stop 31. Early rhyolite obsidian of Sawmill dome and} elevated erratics (03292/41696). Exposed rocks on the caldera's resurgent uplift are almost entirely the phenocryst-poor postcaldera rhyolite (74-75 percent $\mathrm{SiO}_{2}$ ) that Bailey (1989) named the "early rhyolite" (750-640 ka). Erupted from several vents, the early rhyolite has a known eruptive volume as great as $100 \mathrm{~km}^{3}$ (McConnell and others, 1995; Hildreth and others, 2017). Drilling has shown the assemblage to be as thick as $622 \mathrm{~m}$ near the center of the uplift and $537 \mathrm{~m}$ beneath the caldera's West Moat where it is deeply buried by younger units (Hildreth and Fierstein, 2016a).

We remapped the early rhyolite at a scale of 1:24,000 and subdivided its exposures into 14 eruptive units (fig. 38) on the basis of composition, lithology, and field relations (Hildreth and others, 2017). The lavas include coulees and domes that consist of four main lithologies - felsite (partly to wholly devitrified stony lava), perlite (hydrated dense glassy lava), pumiceous carapace (finely vesicular glassy exterior zones of lavas, also hydrated), and obsidian (mostly dense, black, and nonhydrated or weakly so). All four lithologies are typically flow foliated and commonly folded convolutely, most prominently so in felsites. Felsite is by far the most extensive of the four, but scattered outcrops of the other three are abundant and widespread. Obsidian and felsite are widely interlaminated. The pyroclastic facies of the early rhyolite (Stops 32, 33), although predominant volumetrically, is pervasively hydrated, widely silicified, argillized, or otherwise altered, poor in pumice larger than $1 \mathrm{~cm}$, and poorly exposed. It too is phenocryst-poor high-silica rhyolite. Two lava units and most of the pyroclastic deposits are aphyric, while other units contain only $0.2-2.5$ weight percent small phenocrysts. These units all contain plagioclase, orthopyroxene, and Fe-Ti oxides. Biotite is recognized in seven units but is very sparse in some of them and absent in others. Trace amounts of zircon, apatite, and sulfide blebs are present, but quartz, sanidine, clinopyroxene, and amphibole are absent.

Sawmill Dome and Lookout Mountain are the two strictly aphyric early rhyolite lavas. Two obsidians from Sawmill Dome separated in heavy liquids yielded zero crystals in one and $\sim 50 \mathrm{ppm}$ plagioclase and orthopyroxene microphenocrysts in the other. The dome rises $160 \mathrm{~m}$ above 
Sawmill Road at the southwest end of the resurgent uplift, where it overlies a sparsely porphyritic early rhyolite coulee. Altogether $2 \mathrm{~km}$ long and $1 \mathrm{~km}$ wide, the unit consists of an obsidian-capped summit vent dome (elevation 2,507 m; BM 8224) from which flow lobes extend northwest and southeast. Its northeast margin is a 200-m-high boundary fault of the Smokey Bear Flat graben. Its 150-m-high southwest scarp was glacially eroded during one or more glacial advances, the penultimate of which deposited the MIS-6 Casa Diablo Till (Stop 25) against its lower slope. Obsidian collected here at the summit gave a K-Ar age of $694 \pm 17 \mathrm{ka}$ (Mankinen and others, 1986).

Clusters of basement erratics, many $50-150 \mathrm{~cm}$ across, are common on Sawmill Dome and on the subjacent coulee along the ridge that forms the west-facing flank of the resurgent uplift. Here, one cluster is at a bend in the road just east of the summit. Erratics are common at $\sim 2,450 \mathrm{~m}$ elevation, but some are as high as 2,470-2,490 m. Four Mesozoic lithologies predominate (Hildreth and Fierstein, 2016a, b) - equigranular Round Valley Peak Granodiorite, porphyritic Mono Creek Granite, leucogranite, and metavolcanic rocks, all well exposed in the glacially eroded Sierra Nevada a few kilometers to the south and west. Absence of accompanying clasts of Bishop Tuff shows that the blocks were not explosively entrained from older glacial deposits buried in the caldera fill. Absence of erratics of Mammoth Mountain trachydacite (100$50 \mathrm{ka})$ and the many glaciated mafic lavas (230-16 ka) widely exposed on the western floor of the caldera (Hildreth and others, 2014) shows that the basement erratics were emplaced relatively early in middle Pleistocene time. In common with numerous clusters of similar erratics east of the graben, above the geothermal plant, also on a west-facing ridge, it is inferred that the blocks were rafted across an early postcaldera lake by icebergs that grounded against windward shorelines prior to resurgent uplift of the rhyolite. Their present elevations require uplift of 220-260 m relative to littoral sandstone (exposed only as high as 2,230 m near the geothermal plant $\sim 2.5 \mathrm{~km}$ southeast) that marks the middle Pleistocene $(\sim 180 \mathrm{ka})$ highstand of intracaldera Long Valley Lake (Hildreth and Fierstein, 2016b).

From the cloverleaf intersection of Highways 203 and 395, drive 200 m east of the overpass and turn left on a poorly paved road. Proceed $\sim 1.0$ mile north and turn right on Antelope Springs Road. Go 1.5 miles uphill on the winding road, and at a five-way fork in the road (03319/417025), take it (Berra, 2001). The main road stays on contour, bending around the head of Fumarole Valley, which lies below on the right. After another $\sim 1.5$ miles, stop at a big white roadcut in nonwelded ignimbrite (03333/41710).

Stop 32. Early rhyolite ignimbrite roadcut at head of Fumarole Valley (03333/41710). Lava flows dominate exposed parts of the early rhyolite (fig. 38), but drillholes indicate that pyroclastic deposits are volumetrically far predominant. Exposure of the tuffs is generally poor because they are poorly indurated at near-surface levels and they degrade readily into slopes mantled in thick colluvium. The early rhyolite pyroclastic deposits consist predominantly of white nonwelded high-silica-rhyolite ignimbrite, massive to vaguely stratified, but they locally include intervals a few meters thick in which thin pumice-fall, surge, or hybrid-fall layers are intercalated. The deposits are mapped over an area of $21 \mathrm{~km}^{2}$ and extend continuously for $8 \mathrm{~km}$ southeast from Dry Creek to Hot Creek (fig. 38). The map pattern and drillhole data show, however, that the tuff is present over a far greater subsurface area (in all directions), buried by early rhyolite and younger rhyolitic lava flows, by various mafic lava flows, and by lacustrine siltstones that were in part reworked from the tuff itself. Outcrop relief nowhere exceeds $40 \mathrm{~m}$, but total relief on the tuff surface is $230-250 \mathrm{~m}$. The base of the early rhyolite tuff is nowhere exposed but is shown by drilling to rest on intracaldera Bishop Tuff in several wells (Hildreth and Fierstein, 2016a; Hildreth and others, 2017). Along the eastern limits of its outcrop, near the Clay Pit Mine and Little Hot Creek, the tuff is overlapped by and interfingers with sedimentary pumice breccia and ash-grade lacustrine siltstone, both of exclusively rhyolitic derivation. The tuff is not directly dated but is bracketed by the Bishop Tuff ( $767 \pm 2 \mathrm{ka}$ ) and an early rhyolite obsidian flow (751 $\pm 16 \mathrm{ka})$.

Outcrops are white to cream, weakly to moderately indurated but locally case-hardened or pervasively silicified, and uncommonly medium-gray or greenish-gray where altered. Exposures are nonwelded, but partial welding is reported at depth in some cores (McConnell and others, 1995). The tuff is poorly sorted, ash-dominant, and rich in small pumice fragments - mostly $0.2-2 \mathrm{~cm}$ and rarely $3-5 \mathrm{~cm}$. Where the tuff is not massive, vague gradational layers, 3-150 cm thick, are defined by alternating pumice-poor and pumice-bearing intervals (fig. 39). Pumice lapilli and granules are only locally concentrated into lenses or thin layers. Locally exposed within otherwise massive tuff sections, however, are packages 1-2 m thick that consist of many thin $(2-20 \mathrm{~cm})$ planar beds rich in pumice granules, separated by laminae of medium ash typically only $1-2 \mathrm{~cm}$ thick.

All pumice is aphyric or nearly so, containing trace amounts of orthopyroxene, biotite, and plagioclase at only a few exposures. The few pumice clasts analyzed are similar to the early rhyolite lavas in major and trace elements, but they yield low totals (92.8-94.5 percent) and low $\mathrm{Na}_{2} \mathrm{O}(2.5-3.0$ percent) owing to $\mathrm{Na}$ loss on hydration. Lithic fragments are typically sparse to rare, and nearly all are cognate aphyric rhyolite lava - dense, glassy, and mostly smaller than $2 \mathrm{~cm}$.

The stratified nonwelded ignimbrite in the roadcut here occupies a saddle between Fumarole Valley and Little Antelope Valley. Although both valleys are in part structural, much of their depth owes to erosive removal of nonwelded tuff. The exposure, $10 \mathrm{~m}$ high, is ash-dominant and poor in pumice fragments, most of which are $2-15 \mathrm{~mm}$, rarely $30 \mathrm{~mm}$. Pumice ranges from frothy to moderately dense and is sparser and smaller than in many other exposures. No lithics were observed except bits of dense cognate glass. Vaguely defined layers 


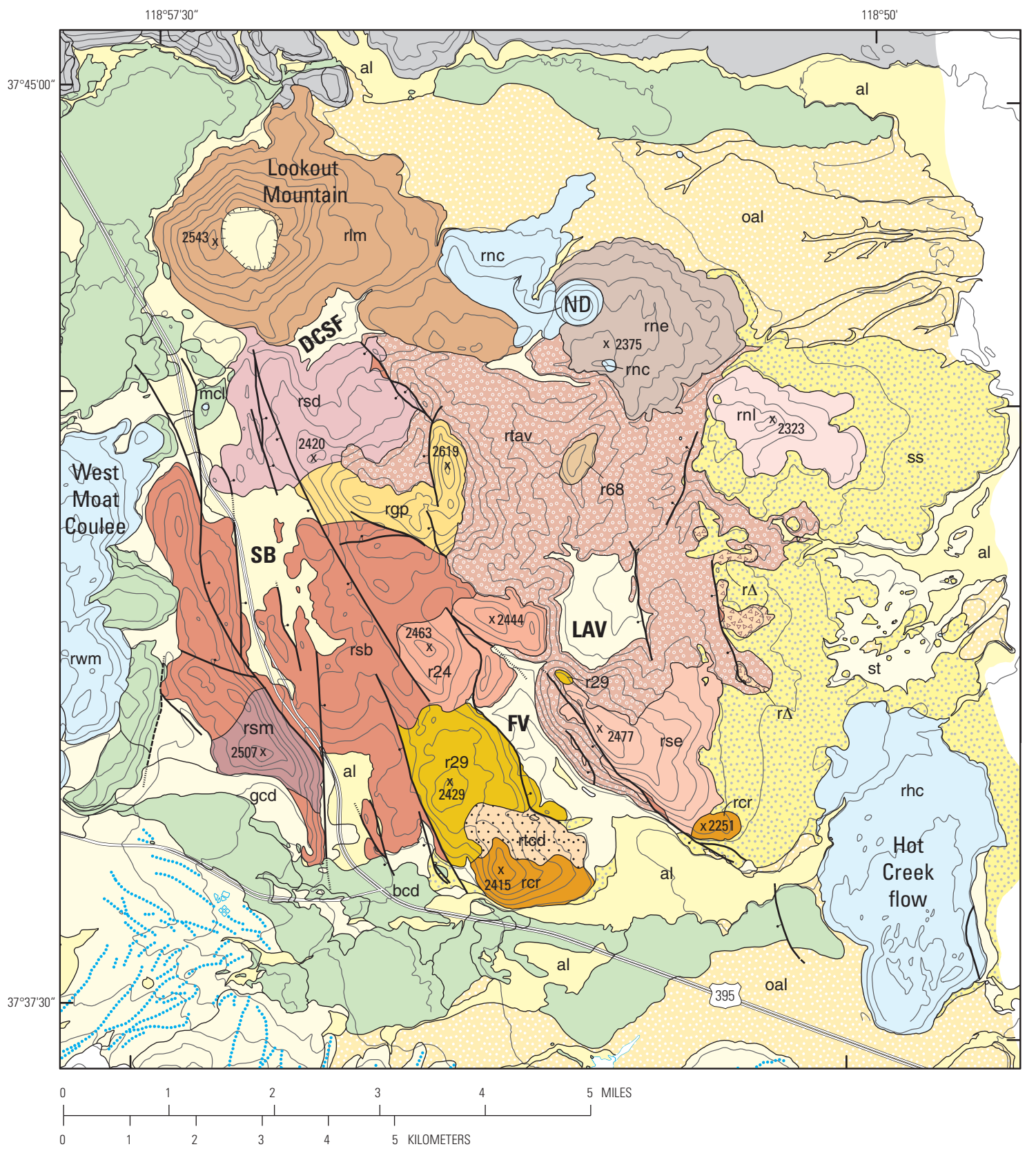

EXPLANATION

\begin{tabular}{|c|c|}
\hline+ & Normal fault; dotted where concealed \\
\hline & Volcanic crater or partial crater rim \\
\hline .... & Moraine crests \\
\hline al & active alluvium \\
\hline bcd & basalt of Casa Diablo Hot Springs \\
\hline gcd & Casa Diablo Till \\
\hline $\mathrm{mcl}$ & basaltic trachyandesite of Canyon Lodge \\
\hline oal & Pleistocene alluvium \\
\hline $4 A^{\circ}$ & early rhyolite breccia \\
\hline r24 & rhyolite of Dome 2463 \\
\hline r29 & rhyolite of Dome 2429 \\
\hline r68 & pumice cone 2368 \\
\hline $\mathrm{rcr}$ & rhyolite north of Chance Ranch \\
\hline rgp & rhyolite of Gilbert Peak \\
\hline rhc & Hot Creek flow \\
\hline
\end{tabular}

\begin{tabular}{|c|c|}
\hline $\mathrm{rlm}$ & rhyolite of Lookout Mountain \\
\hline rnc & rhyolite of north-central chain \\
\hline rne & rhyolite of Northeast Coulee \\
\hline $\mathrm{rnl}$ & rhyolite north of Little Hot Creek \\
\hline $\mathrm{rsb}$ & rhyolite of Smokey Bear Flat \\
\hline rsd & rhyolite south of Dry Creek sand flat \\
\hline rse & rhyolite of Southeast Coulee \\
\hline rsm & rhyolite of Sawmill dome \\
\hline rtav & tuff of Little Antelope Valley \\
\hline$\therefore$ itcd: & tuff east of Casa Diablo \\
\hline rwm & rhyolite of West Moat Coulee \\
\hline ss & littoral deposits of Pleistocene caldera lake \\
\hline st & siltstone of Long Valley caldera lake \\
\hline
\end{tabular}


Figure 38. Map of early postcaldera rhyolite subdivided into 14 eruptive units, labelled as described by Hildreth and others (2017). Two units (rtav, the tuff of Little Antelope Valley, and rtcd, tuff east of Casa Diablo) are pyroclastic; unit r68 is pumice cone 2368; and the other 11 are lavas. All were deformed by structural resurgent uplift except unit rlm (rhyolite of Lookout Mountain) in the caldera's northwest moat. For unlabelled peripheral units, see geologic map of Hildreth and Fierstein (2016a). Moat rhyolites in blue (ND, North Dome; also see fig. 7) and mafic lavas in green are all younger than early rhyolite (750-640 ka). Older units of precaldera north wall are in gray. Surficial units: ss, littoral deposits of Pleistocene caldera lake; oal, Pleistocene alluvium; al, active alluvium; Marine Isotope Stage 2 (Tioga glaciation) moraine crests are dotted blue in southwest corner. Abbreviations: DCSF, Dry Creek sand flat; FV, Fumarole Valley graben; LAV, Little Antelope Valley; SB, Smokey Bear Flat graben. Selected elevations in meters above sea level are indicated by $\mathbf{x}$. Knoll x2507 in unit rsm (rhyolite of Sawmill dome) is site of Stop 31. West rim of crater on Lookout Mountain (unit rlm, rhyolite of Lookout Mountain) is site of Stop 34. Graben faults cut many early rhyolite units but not Lookout Mountain.

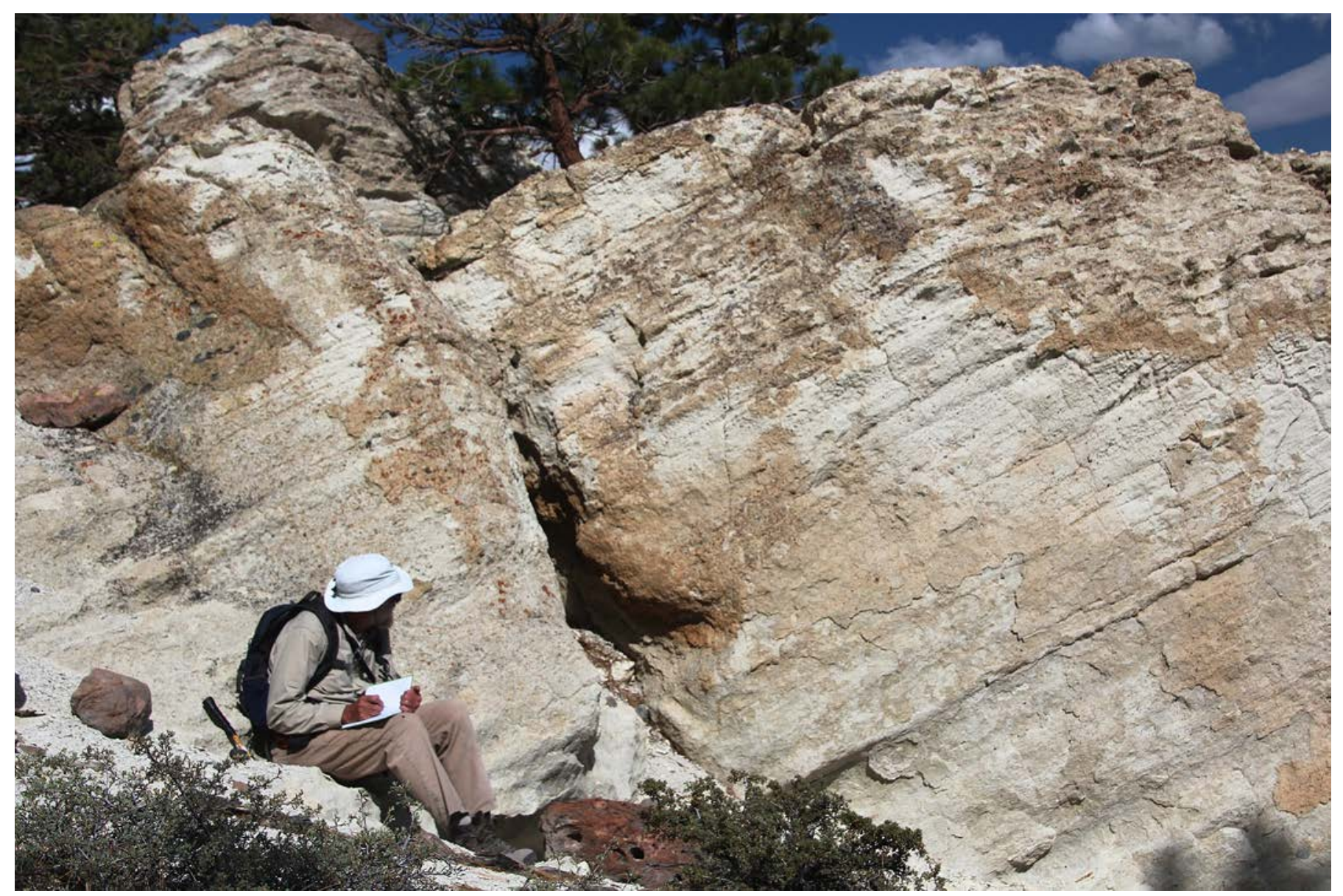

Figure 39. Photo of nonwelded ignimbrite - massive to vaguely stratified, weakly indurated rhyolite tuff typical of early rhyolite (750-640 ka). Exposure is at UTM 03325/41729, 1 km southeast of Gilbert Peak. Layers are planar or low-angle lenticular, 1-5 cm thick, and ash-dominant but defined by varied abundance of small distributed lithics; less common are fines-dominant layers $20-50 \mathrm{~cm}$ thick. Most lithics are angular rhyolite lava, 3-50 mm, along with rare larger clasts of Bishop Tuff and basalt. Lithic content ranges from $<1$ percent to as much as 5 percent and is seldom concentrated in stringers or lithic-enriched layers. Rounded pumice (1-10 mm) is $10-15$ percent of most layers, rarely as much as 30 percent. The section strikes northwest and dips $\sim 25^{\circ} \mathrm{NE}$. 
3-50 cm thick reflect variations from pumice-free to pumicepoor. The section dips $10^{\circ} \mathrm{W}$.

From the roadcut at Stop 32, continue downhill toward Little Antelope Valley and at an intersection after 0.8 mile (033365/41719), stay left on road 3 S12 toward Chalk Bluffs. Continue north for $\sim 1.2$ miles and park beside the road (033375/41735) below a slope marked by eroded spires of white tuff.

Stop 33. Chalk Bluffs hoodoos in early rhyolite ignimbrite. This is the same voluminous unit visited at Stop 32. Eroded cones of vaguely stratified nonwelded ignimbrite crop out on a tuff slope altogether $80 \mathrm{~m}$ high. Gradational layers reflect variation of pumice abundance in the ash-dominant matrix, ranging from pumice-rich to pumice-poor. Most pumice is $2-30 \mathrm{~mm}$, rarely $40-55 \mathrm{~mm}$. Systematic separation of a kilogram of pumice lapilli from this site yielded 12 ppm plagioclase, no mafics, and 99.9988 weight percent glass. Most of the vaguely defined layers are 5-25 cm thick, but some are as thick as $150 \mathrm{~cm}$. A few sets of thinner $(1-5 \mathrm{~cm})$ layers form intervals $1-2 \mathrm{~m}$ thick that are slightly oblique to enclosing bedsets that are generally plane-parallel. Cross bedding is uncommon. Lithics are sparse, mostly cognate felsite or obsidian, few $>2 \mathrm{~cm}$ and only rarely $5 \mathrm{~cm}$. The tuff exposed is poorly indurated, hydrated but not silicified or otherwise altered. The section dips $10^{\circ}-20^{\circ} \mathrm{NE}$., probably tilted during structural resurgence. A second set of similar hoodoos, $600 \mathrm{~m}$ northwest $(03333 / 41740)$ has a higher proportion of layers rich in pumice, a few ash-dominant layers as thick as $1-2 \mathrm{~m}$, more rhyolite lithics (2-3 percent), and sparse fragments of welded Bishop Tuff (5-25 cm).

From Stop 33, continue northwest on road 3 S12 for $\sim 2.5$ miles until it bends left into road 3S06. This road crosses Dry Creek sand flat and after $\sim 1.5$ miles makes a hairpin turn to the left.

After another $\sim 1.5$ miles, it merges with road 2S02, onto which a sharp right turn leads you up Lookout Mountain. Alternatively, from Stop 33, return to Highway 395 and follow the route described next.

From the cloverleaf intersection of Highways 203 and 395, drive 5.2 miles north on 395 and turn right on a gravel road across the highway from the junction of the paved "Scenic Loop." The road starts eastward beside Dry Creek, which marks the structural and topographic boundary between the resurgent uplift and the Lookout Mountain edifice. After 0.6 mile, keep left at a fork in the road, and after another 0.35 mile, keep left again on road 2S02. This road winds $\sim 2.1$ miles to a carpark loop on the west summit (elevation 2,543 m) of Lookout Mountain (03284/41773). [Unless you have special interest, ignore right turn $2 S 02 \mathrm{~A}, \sim 0.6$ mile before the summit, which leads onto the forested crater floor of the edifice.]

Stop 34. Lookout Mountain (03284/41773). Lookout Mountain is extraordinary for a rhyolite volcano in having a $1-\mathrm{km}-$ wide summit crater and in having shield-like flanks armored by obsidian lava flows. Outcrops around the circular crater rim are predominantly obsidian that forms a series of knolls and ridges separated by five shallow saddles and notches. No pyroclastic deposit is exposed that might account for the crater; the edifice was not glaciated, the crater floor is not gullied, and narrow rim notches are only weakly incised, rendering unlikely an erosional origin for the crater. A thick lava-flow lobe that extends $2 \mathrm{~km}$ southeast from the 4-km-wide edifice raises the speculation that the summit depression reflects subsurface magma withdrawal, but that would be an unexpected mechanism for a rhyolite volcano. (Cratered dome at nearby Glass Creek may record a similar process [Hildreth and Fierstein, 2016a]).

Like Sawmill Dome (Stop 31), all eruptive products of Lookout Mountain are aphyric. Mafic enclaves were sought but none found. The 12 obsidians analyzed, representing all parts of the edifice, are remarkably uniform chemically; their range, for example, in $\mathrm{SiO}_{2}$ is $74.88-74.93$ percent, in $\mathrm{Na}_{2} \mathrm{O}$ is $3.84-3.88$ percent, and in $\mathrm{Sr}$ is $85-87 \mathrm{ppm}$. Obsidian yielded K-Ar ages of $692 \pm 14 \mathrm{ka}$ and $677 \pm 14 \mathrm{ka}$ (Mankinen and others, 1986), whereas several glass and plagioclase experiments gave a range of ${ }^{40} \mathrm{Ar} /{ }^{39} \mathrm{Ar}$ ages, $680-610 \mathrm{ka}$ (Hildreth and others, 2017).

If one walks around to avoid trees, the summit area provides good views across much of the caldera. Southward, the Smokey Bear Flat graben transects the western part of the resurgent uplift. Beyond the south moat, Paleozoic marine strata make up most of the caldera's steep south wall. To the southeast, Gilbert Peak is the highest point on the uplift, and beyond it lies the Long Valley lowland, site of white silt deposits of the middle Pleistocene caldera lake. To the east, 570-ka North dome is $6 \mathrm{~km}$ away, and $\sim 20 \mathrm{~km}$ away is the early Pleistocene Glass Mountain rhyolitic edifice (2.2-0.8 Ma), which is cut by the caldera's northeast wall. To the west is the 1350 C.E. Inyo chain and, beyond the west moat, the caldera wall consists of Paleozoic metasedimentary rocks overlain by a stack of 3.7-3.2 Ma trachybasalt lavas, which is capped in turn by 3.0-2.6 Ma domes and pyroclastic deposits of trachydacite. To the southwest is the Mammoth Mountain trachydacite edifice $(100-50 \mathrm{ka})$, which is banked against glaciated granite of the caldera's topographic wall (Stops 1-4 and 6-9).

To Stop 35 from Lookout Mountain (Stop 34), return to Highway 395 and turn right. In 3 miles, turn left on Deadman Creek Road (03255/41792). If not coming from Stop 34, follow the route described next. From the cloverleaf intersection of Highways 203 and 395, drive 8.2 miles north on 395 and (having passed the right turn for Owens River Road at 7.3 miles) turn left on Deadman Creek Road (03255/41792). Go southwest for $\sim 0.3$ mile and stop on the shoulder for a view westward.

Stop 35. Deadman Creek view of White Wing Mountain and Glass Creek flow. To the west, the rugged rhyolitic Glass Creek flow drapes the caldera wall (fig. 40), of which the forested segment to the right consists of Pliocene mafic lava flows. Beyond the barren draping coulee rises White Wing Mountain, a segment of the caldera wall that consists of Mesozoic granite heavily mantled by pumiceous fallout, most of which was 
ejected from the vent that subsequently extruded the Glass Creek flow. The flow banks against and covers the trace of the Hartley Springs Fault, a strand of the range-front fault system. The sagebrush flat beneath us is floored by an apron of 33-ka mafic lava flows that erupted at a scoria cone $\sim 8 \mathrm{~km}$ southwest of here.

Compositionally complex lava flows and pumiceous ejecta (70-74 percent $\mathrm{SiO}_{2}$ ) issued from three separate vents along a north-south dike that propagated southward along the fault zone to produce the 5-km-long Inyo Chain (Miller, 1985). To the north is the Obsidian flow and to the south the Deadman Creek flow and some phreatic vents named the Inyo Craters. The Glass Creek vent was the last of the three magmatic vents to open. It released $\sim 0.1 \mathrm{~km}^{3}$ of pumiceous fallout, as thick as $10 \mathrm{~m}$ proximally, that extends more than $190 \mathrm{~km}$ southward (Wood, 1977), the most widespread and voluminous explosive product of the sequence. Along the crest of White Wing Mountain, where fallout is $8 \mathrm{~m}$ thick, tree-ring study of logs and stumps killed by the eruption pinned the event to late summer of 1350 C.E. (Millar and others, 2006). The outburst was followed by extrusion of $\sim 0.1 \mathrm{~km}^{3}$ of lava as the blocky Glass Creek flow. From its vent on the caldera rim, the 700-to-900-m-wide flow spread $\sim 500$ m northward (to a steep northerly flow-front as high as $75 \mathrm{~m}$ ) as well as $\sim 1 \mathrm{~km}$ southward, descending $220 \mathrm{~m}$ in elevation to the foot of the caldera wall at Stop 36.

From Stop 35, continue southwest on Deadman Creek Road. At the end of the long straightaway, 1.2 miles from Highway 395, turn right toward Crestview guard station (White Wing Camp). Ignore the camp buildings on the right and drive 0.4 mile northwest toward the caldera wall. At a T-junction (032365/41786), turn left and go 0.3 mile uphill on a bumpy unpaved road. Where it levels out, pull carefully off the road to park on the apron of coarse ejecta near the terminus of the wall-draping Glass Creek coulee of 1350 C.E.

\section{Stop 36. Mingled rhyolites at the south margin of the Glass Creek flow (03229/417835). The blocky flow-front} breccia exposes limited mingling of contrasting rhyolites, one mostly black and phenocryst-poor ( $2-3$ percent crystals) and the other white or gray with $25-40$ percent crystals. The fluid behavior of the first (70-74 percent $\mathrm{SiO}_{2}$ ) contrasts with the more viscous to brittle behavior of the crystal-rich material (71.3 \pm 1 percent $\mathrm{SiO}_{2}$ ). The latter piled up over the vents of the Deadman Creek and Glass Creek flows late in their extrusive episodes and mingled (to a limited extent) locally with the

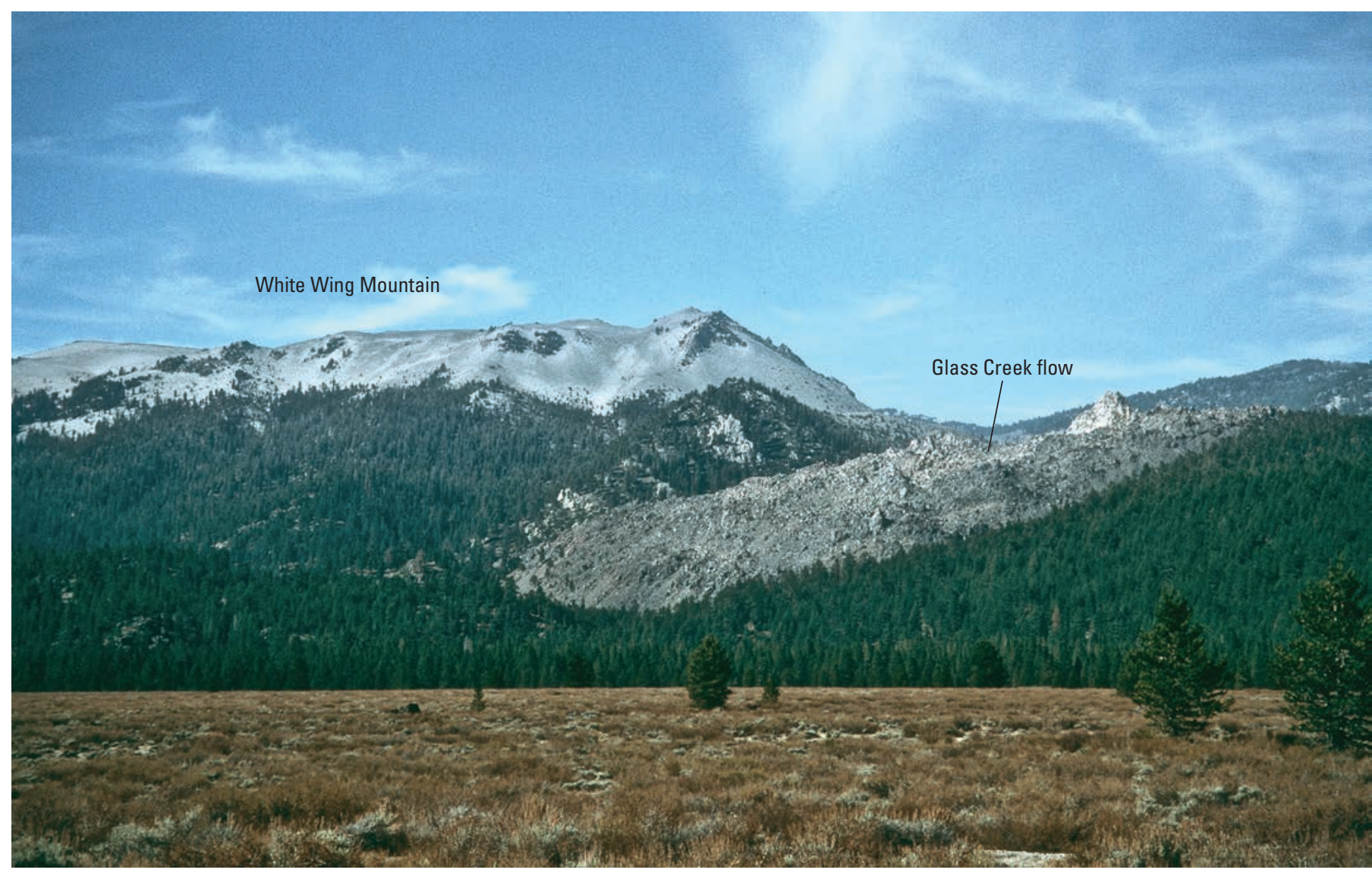

Figure 40. Photo of Glass Creek flow draping caldera's northwest wall, 3 km west of Highway 395 at Crestview. Rugged rhyolitic coulee covers trace of Hartley Springs Fault, which separates Pliocene intermediate lavas that form caldera wall at right from Mesozoic granite that forms wall at left. On skyline is granitic White Wing Mountain, thickly mantled with pumiceous fallout, much of it ejected from the nearby vent that subsequently extruded the Glass Creek flow. Tree-ring study of logs and stumps killed by the eruption atop White Wing Mountain pinned the event to late summer of 1350 C.E. (Millar and others, 2006). View west from Stop 35. 


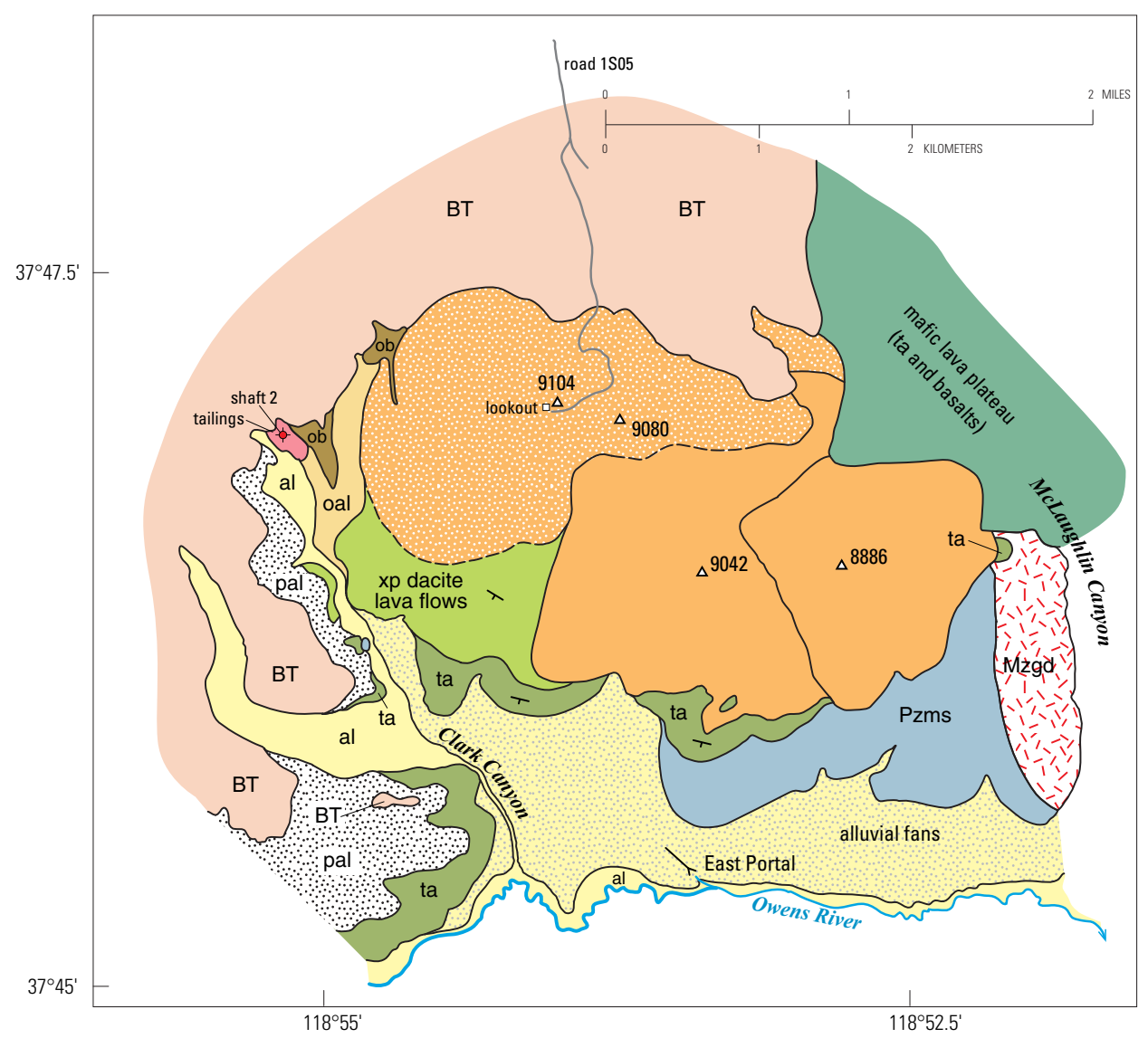

Figure 41. Sketch map of precaldera Bald Mountain complex on northcentral rim of Long Valley Caldera. All volcanic units are Pliocene except the Bishop Tuff (BT), the 767-ka calderaforming ignimbrite. Basement rocks are Paleozoic siliceous, pelitic, and calcsilicate hornfels (Pzms) and Mesozoic hornblende-biotite granodiorite (Mzgd). Oldest volcanic rocks exposed here are $\sim 3.7 \mathrm{Ma}$ trachyandesite lava flows (ta). Next oldest is a stack of phenocryst-poor (xp) trachydacite lava flows, overlain in turn by the set of three large hornblendebiotite trachydacite-trachyandesite domes. Summit dome 9104 (stippled) is crystal-rich; the other two, 9104 and 8888 , are crystal-poor. Youngest precaldera volcanic unit is olivine basalt (ob), which banks against Bald Mountain summit dome. Precaldera alluvium (pal) that underlies the Bishop Tuff is as thick as $150 \mathrm{~m}$ in vicinity of shaft 2 at head of Clark Canyon. Postcaldera alluvium: oal, Pleistocene; al, active. Tailings from shaft 2 are fluvial gravels of precaldera Owens River that were dumped during 1934-1939 driving of the Mono Craters tunnel (Jacques, 1940; Gresswell, 1940), the terminus of which is East Portal where Mono Basin water is released into the Owens River. coerupting crystal-poor magma. Evidently having been stored separately, the crystal-rich magma was $\sim 100{ }^{\circ} \mathrm{C}$ cooler and chemically unrelated to the crystal-poor one, which has much higher $\mathrm{K}, \mathrm{Rb}, \mathrm{Zr}$, Y, and REE (and lower $\mathrm{Ti}, \mathrm{Mg}, \mathrm{Ca}$, and $\mathrm{Sr}$ ) at equivalent $\mathrm{SiO}_{2}$ contents. In addition to the silicic magmas, andesitic enclaves $\left(\sim 60\right.$ percent $\left.\mathrm{SiO}_{2}\right)$ are present in the crystal-rich central parts of both flows (Varga and others, 1990).

The main crystal-poor magma was itself zoned (70-74 percent $\mathrm{SiO}_{2}$ ), yielding smoothly linear compositional arrays (for example, 1.3-2.6 percent $\mathrm{FeO}^{*}$ and 265-1,420 ppm $\mathrm{Ba})$, which are continuous but show an apparent tendency toward volumetric bimodalism (Sampson and Cameron, 1987; Vogel and others, 1989). To explain the arrays, Sampson and Cameron (1987) suggested back-mixing between two slightly zoned silicic magmas that had earlier fractionated at higher pressure, while Vogel and others (1989) called for mixing between dacitic and rhyolitic end-members. Bailey and others (1976) had suggested that the crystal-poor phase might be Mono Chain magma (which may be at least partly right) and that the crystal-rich phase is Long Valley magma (which appears to be wholly right). The compositional and petrographic similarity of the crystal-rich Inyo phase and the nearby Long Valley rhyolite of Deer Mountain was pointed out by Sampson and Cameron (1987). Moreover, Reid and others (1997) identified, in both the 1350 C.E. crystal-rich Inyo phase and 115-ka Deer Mountain lava, zircon populations with crystallization ages that cluster around $230 \mathrm{ka}$. Residual or thermally rejuvenated Long Valley magmatic mush is apparently implicated. The crystal-rich rhyolite is not present in the 1350 C.E. Obsidian flow, which is well outside the caldera. It was encountered only when the Inyo dike (Eichelberger and others, 1985), advancing southward along the range-front fault, approached and crossed the caldera margin.

Stop 37. Long drive to Bald Mountain summit. From Highway 395 near Deadman Summit, opposite the southwest turn for the Obsidian flow, take the Bald Mountain Road (1S05) northeastward. At a 3-way fork after 3.6 miles, take the middle fork, which bends right and remains road 1S05. At a fork 1.5 miles farther on, bear left on road 1S05, where road $2 S 09$ straight ahead is signed to Big Springs Campground. Ignoring several more major side roads, stay on road 1S05, which winds its way for $~ 6$ miles more to the Bald Mountain Lookout. On a clear day, this site provides the best overview of Long Valley Caldera and its surroundings.

Bald Mountain is a Pliocene trachydacite dome complex (fig. 41). The summit dome here is at an elevation of $2,775 \mathrm{~m}$, 
$\sim 630 \mathrm{~m}$ above the caldera's north moat. The dome is rich in hornblende, biotite, and plagioclase and has 66-68 percent $\mathrm{SiO}_{2}$. Three domes just southeast of the summit, however, are phenocryst-poor and have only 60-62 percent $\mathrm{SiO}_{2}$. The lower slopes of the edifice, eroded deceptively smooth, consist of stacks of phenocryst-poor lava flows with $\sim 64$ percent $\mathrm{SiO}_{2}$, which in turn overlie a 100-m-thick stack of trachyandesite lavas (55-57 percent $\mathrm{SiO}_{2}$ ) that rests on Paleozoic metasedimentary basement at the south toe of the edifice. Pliocene basalts and Bishop Tuff bank against the northwest side of the edifice at Clark Canyon and against the northeast side at McLaughlin Canyon. ${ }^{40} \mathrm{Ar} /{ }^{39} \mathrm{Ar}$ dating (unpub. data) has given us ages of $\sim 3.7 \mathrm{Ma}$ at the base and $\sim 3.5 \mathrm{Ma}$ at the top of the Bald Mountain andesite-dacite complex.

The summit provides a panoramic view of the whole caldera region. To the east, beyond a sagebrush-covered expanse of Pliocene basalts, is the forested Glass Mountain complex of early Pleistocene rhyolites. To the south, also forested, is the irregular highland of early rhyolite that was raised 400 $\mathrm{m}$ by postcaldera resurgence. To its left (east) lies the Long Valley lowland, site of the Pleistocene caldera lake. Mammoth Mountain rises high above the caldera's southwest margin, separating pre-Cenozoic rocks of the caldera's steep south wall from its west wall, where Pliocene basalts and dacites rest on Paleozoic and Mesozoic metamorphic rocks. To the northwest is the chain of Mono domes, many of them Holocene. To the north is Mono Basin, a Pleistocene structural depression that lies beyond a forested plateau of Bishop Tuff, which is heavily mantled by pumiceous fallout from the Mono chain.

Alternative return route from Bald Mountain: Instead of retracing the approach route, consider driving back by way of Mono Craters and Mono Lake. From the Bald Mountain Lookout, follow road 1S05 for about 4 miles north and turn right on road 1S12. After about 4.5 miles on this winding road, turn left on road 1S17. In another $\sim 1.5$ miles, you reach paved Highway 120. A left turn here takes you close to the North Coulee, Panum Crater, and other domes of the Mono Chain en route back to Highway 395. Most of the Mono Chain consists of domes, coulees, and voluminous pumiceous fallout, but only a few craters. The system has produced at least 30 eruptions since $\sim 60 \mathrm{ka}$, many of them in the Holocene and nearly all of high-silica rhyolite. Despite compositional and volcanological similarities to precaldera Glass Mountain, however, the Mono system is independent of Long Valley and Mammoth Mountain; and, thus, alas, it is not dealt with in this guidebook!

Stop 38. Devils Postpile and Rainbow Falls. Visiting these outstanding geological features along the Middle Fork San Joaquin River canyon would require at least half a day. The trip might best be taken after Stop 5 at Minaret Vista, which is on the divide overlooking the canyon. In summer months, you are required to take a shuttle bus down the narrow winding road to Devils Postpile National Monument (DPNM). Off-season (or if you arrange a group permit), you can drive down the 10-mile paved road, forks of which end at the DPNM ranger station and at the nearby trailhead for Rainbow Falls. The trail walk from the ranger station over Devils Postpile and back would take about two hours. The 2-mile trail downstream to Rainbow Falls would take an hour each way.

Devils Postpile is a spectacular colonnade in one of several glacially eroded remnants of a single intracanyon flow of phenocryst-rich basaltic trachyandesite (53.9-54.4 percent $\mathrm{SiO}_{2}$ ), which has been ${ }^{40} \mathrm{Ar} /{ }^{39} \mathrm{Ar}$ dated at $82 \pm 2 \mathrm{ka}$ at two widely separated locations (Hildreth and Fierstein, 2016a). Remnants extend discontinuously for $7 \mathrm{~km}$ along the canyon floor, directly overlying Cretaceous granite. The vent has not been identified, but it should not be confused with the scoria cone near Upper Soda Springs Campground, which is the source of a phenocryst-poor mafic lava flow dated at $121 \pm 2 \mathrm{ka}$. The iconic colonnade exhibits slender polygonal columns 15-20 m long, variously vertical, curved, inclined, or subhorizontal, as well as a remarkable postglacial talus of fallen columns and an icepolished polygonal mosaic on a bench atop the principal colonnade. Evidence for ice-contact emplacement is not observed and would not have been expected here at the interglacial time of eruption. Glacial plucking and polishing took place during MIS 2. Phenocrysts include 7-10 percent plagioclase, 2-3 percent olivine, and $\sim 1$ percent clinopyroxene. By coincidence, the 110-m original thickness of the flow is the same as that of 1959 Kilauea Iki lava lake (Hawaii), which took 20-25 years to solidify fully, while producing audible cracking as polygonal contraction joints advanced incrementally into the thickening crust (Peck and Minakami, 1968; Ryan and Sammis, 1978).

At Rainbow Falls, the Middle Fork drops $30 \mathrm{~m}$ vertically over the platy ledge of an intracanyon coulee of phenocrystpoor trachydacite (65.7-67.1 percent $\mathrm{SiO}_{2}$ ). Glaciated remnants of the flow extend $6 \mathrm{~km}$ downstream from Reds Meadow, where the 99-ka flow had apparently come down the canyon wall from a vent on the later site of Mammoth Mountain. Icescoured outcrops are 30-40 m thick in the north and as thick as $80 \mathrm{~m}$ in the south. The coulee filled paleochannels cut in Cretaceous granite, and its emplacement forced the river to cut a striking meander $250 \mathrm{~m}$ in amplitude, $\sim 800 \mathrm{~m}$ upstream from the falls. Where exposed atop granite, the basal zone includes vertical prismatic joints that locally form slender polygonal columns 3-8 $\mathrm{m}$ high, overlain by an abrupt transition to the flow interior, which almost everywhere is flow foliated and splits platy. Phenocrysts include 1-3 percent plagioclase, rare biotite, sparse orthopyroxene, and traces of Fe-Ti oxides, with or without sparse hornblende needles. Well exposed along the left-bank (south) rim of the gorge, adjacent to and downstream from the falls, the massive phenocryst-poor 97-ka trachyandesite of Mammoth Pass overlies the platy dacite. The contact is accessible on the stairway that descends to the base of the falls. 


\section{Recent Unrest In and Near Long Valley Caldera}

Geophysical unrest has attracted public and scientific attention here since 1980: principally (1) intermittent uplift of the Pleistocene resurgent dome in the west-central part of the caldera, totaling $83 \mathrm{~cm}$ by 2016 ; (2) cryptic emission of tree-killing $\mathrm{CO}_{2}$ around Mammoth Mountain, and (3) recurrent seismic swarms under Mammoth Mountain, along the caldera's south moat, and most energetically in the Sierran basement block just south of the caldera. In response to the unrest, the U.S. Geological Survey intensified its monitoring, installed a network of seismometers, geodetic instruments, and gas-monitoring equipment, and developed a response plan for potential future volcanic activity.

Here, we summarize the main episodes of unrest recorded to date, based on published contributions: Hill and others, 2002; Prejean and others, 2002; Langbein, 2003; Hill, 2006; Shelly and Hill, 2011; Montgomery-Brown and others, 2015; Shelly and others, 2015, 2016. We then discuss the varied interpretations and the many uncertainties concerning the causes of the unrest.

1978 M5.8 earthquake beneath Wheeler Crest in the Sierra $\sim 15 \mathrm{~km}$ south of the caldera marked the onset of intermittent seismicity (including a few events to M3 and M4) in the caldera's south moat and in the adjacent Sierra.

1980 Four M6 earthquakes in the Sierra (0-10 km south of the caldera, one of them at the caldera wall) initiated an extended interval of elevated seismicity in the Sierra and in the caldera's south moat (soon called the "South Moat Seismic Zone," SMSZ). Two of the four (plus the 1978 event) were shown to have had non-double-couple components.

1980-82 Levelling surveys along Highway 395 measured $25 \mathrm{~cm}$ intracaldera uplift between autumn 1979 and summer 1980. Abundant seismicity continued in the Sierra and the SMSZ, including numerous M3 to M4 events and one M5.9 event in the Sierra $\sim 3 \mathrm{~km}$ south of the caldera in September 1981. By late 1982 there had been $\sim 8 \mathrm{~cm}$ additional uplift.

1983 An intense swarm in the SMSZ that began in January included two M5.3 events and was accompanied by $7 \mathrm{~cm}$ additional uplift centered on the caldera's Pleistocene resurgent structure. Lesser swarms continued throughout 1983 and the first half of 1984. By mid-1983 there had been a total of $\sim 40 \mathrm{~cm}$ uplift since 1979 .

1984-89 Relatively quiescent interval. Low level of seismicity in Sierra and caldera. Uplift rate dropped to $<1 \mathrm{~cm} / \mathrm{yr}$, followed by slight $(1-2 \mathrm{~cm})$ subsidence in 1989 .

1989 Mammoth Mountain seismic swarm began in May and lasted for 11 months; thousands of small earthquakes at $1-10 \mathrm{~km}$ depths, but only three as energetic as $M 3$. Onset of LP (long-period) earthquakes at 10-25 km depths and presumed onset of elevated $\mathrm{CO}_{2}$ flux that became manifest in tree-kill areas by 1990. Both the deep LP activity and the $\mathrm{CO}_{2}$ emission have persisted through 2016. The SMSZ remained quiet and there was no additional uplift in the caldera before September 1989.

1989-96 Modest uplift resumed in autumn 1989, and earthquake swarms resumed in SMSZ in January 1990. About $25 \mathrm{~cm}$ more uplift was recorded by early 1997. Intermittent swarms included episodes in March 1991 (with 22 events $M>3$ ) and late 1993 (with two events M4.0 and M4.1). A brief swarm in late June 1992 (which included events as energetic as M3.7 in the Sierra and M3.4 in the SMSZ) was remotely triggered by the M7.3 Landers earthquake $400 \mathrm{~km}$ south. In 1994-95, seismicity in SMSZ dropped to a low level. In the Sierra, seismicity persisted throughout 1989-1996, with scores of earthquakes $M>3$; an August 1993 swarm had events up to M4.5, and a summer 1995 swarm had $>20$ events stronger than $M 3$, the most energetic at M3.7.

1996 A strong swarm in the SMSZ in March and April 1996 was the most energetic since January 1983. It included $\sim 24$ events of $M 3$ or greater, three of $M 4.0$ to 4.3, and >1,600 located earthquakes. No accompanying deformation was recorded, and uplift rate slowed to $<1 \mathrm{~cm} / \mathrm{yr}$ for 1994-97.

1997 During the first half of 1997, uplift and SMSZ seismicity were at low levels, while Sierran seismicity remained steady, including events of M4.2 and M4.1 just south of the caldera. Beneath Mammoth Mountain, the rate of mid-crustal LP earthquakes increased to $\sim 20$ events per week.

1997 In June, after a year of quiescence, the rates of uplift and SMSZ seismicity both increased strongly, peaking in November, and persisted for the rest of 1997, the most energetic intracaldera episode since January 1983. The entire 15-km-long SMSZ was seismically active at depths of 3-8 km. The episode included 120 events of $M>3$, eight of $M>4$, and $\sim 12,000$ of $M>1.2$. By March 1998, the center of the resurgent dome stood $\sim 10 \mathrm{~cm}$ higher than a year earlier; total uplift reached $\sim 75 \mathrm{~cm}$ since 1979. Mammoth Mountain, quiet since its 1989 swarm, had persistent seismicity at depths to $10 \mathrm{~km}$ from September to December 1997, the only episode in which a Mammoth Mountain swarm coincided with elevated intracaldera SMSZ seismicity. Mammoth Mountain is built on intact Sierran basement and is not in the caldera.

1998-2001 SMSZ seismicity declined to background levels by March 1998 and remained relatively quiescent for 13 years, through 2011. In 1998-2001, there was slight deflation of the resurgent dome. While the caldera was quiescent, the adjacent Sierran block continued to be seismically active, with $\sim 160$ events of $M>3$ from June 1998 through May 1999, the most energetic of which were M5.1, M5.1, and M5.6.

2002-03 Modest uplift resumed in early 2002, adding $\sim 3 \mathrm{~cm}$. The SMSZ remained relatively quiescent, with only seven earthquakes of $M \geq 3.0$. 
2003-11 Sierran seismicity declined but continued at a modest steady level, producing $\sim 50$ events of $3.0 \leq M \leq 4$.6. SMSZ seismicity remained low but steady, producing $\sim 10 M 1-M 2$ events per month; only six events were in the range $3.0 \leq M \leq 3$.8. A minor 3-month swarm in mid-2010 had 235 recorded events of $0.5 \leq M \leq 3.8$, mostly of $M<2.0$.

2011-15 Slow uplift resumed with an abrupt onset in late 2011, coinciding with low-level SMSZ seismicity only slightly above background. Additional uplift of $\sim 3 \mathrm{~cm}$ (centered on the Pleistocene resurgent structure) took place by the end of 2015, for a total of $\sim 83 \mathrm{~cm}$ since 1979. A minor swarm in the SMSZ had $\sim 200$ small events; the largest was M3.0.

2014 An extended five-month swarm of brittle-failure earthquakes southeast of the resurgent dome, including three of M3.5, was studied in detail by Shelly and others (2016). Precise locations for thousands of events recognized rapid upward migration of hypocenters from depths as great as $8 \mathrm{~km}$. The episode was interpreted to have been caused by sustained ascent of pressurized hydrous fluid through the seismogenic crust, weakening a family of cryptic faults within a preexisting fracture mesh.

Mammoth Mountain has had recurrent swarms of brittlefailure earthquakes in the upper $\sim 8 \mathrm{~km}$. A two-week swarm of brittle-failure earthquakes (February 2014), at 3-5 km depths beneath the eastern part of the Mammoth Mountain edifice, included >6,000 located events, most of them $M<1.5$; the largest was $M 3.1$. The swarm was interpreted to represent a transient fluid pressure pulse and concomitant faulting within a distributed fracture mesh (Shelly and others, 2015).

From $10-18 \mathrm{~km}$ beneath the edifice, brittle-failure events are rare, but LP events reflecting fluid ascent in the ductile regime are common (Pitt and others, 2002). Beneath the LP zone and extending southwest of the edifice, high-frequency brittlefailure events have taken place in short-lived swarms, three of which were recorded in 2006, 2008, and 2009 (Shelly and Hill, 2011). Beginning as deep as $31 \mathrm{~km}$ and migrating upward to as shallow as $19 \mathrm{~km}$, the $\sim 24$-hour swarms were interpreted as high-pressure fluid pulses in mafic lower crust.

\section{Long Valley Geophysical Puzzles}

Review and reconsideration of abundant geological and geophysical data led Hildreth (2004) to conclude that the Long Valley rhyolitic magma chamber, so active in the middle Pleistocene, is now moribund. Numerous tomographic attempts to identify a magma body beneath the caldera all failed, and few further attempts were made after 1998 when the Long Valley Exploratory Well (LVEW) corehole found the center of the resurgent dome to be isothermal at $100^{\circ} \mathrm{C}$ between depths of 2 and $3 \mathrm{~km}$.

Uplift of the Pleistocene resurgent area by $\sim 83 \mathrm{~cm}$, in several pulses since 1980, however, has been modelled by some as magmatic intrusion of a prolate spheroid, a textbook model, at a depth of $\sim 7 \mathrm{~km}$ (Langbein, 2003; MontgomeryBrown and others, 2015). Discussion of such an idea-recent ascent into the upper crust, inferred, modelled, or postulatedof a dike or intrusive body of specified or indeterminate shape, whether mafic or felsic, needs first to clarify its conceptual relation to (or distinction from) that of the extensive subcaldera magma chamber envisioned by most investigators prior to 1998. Is the uplift promoted by reactivation of residual magma of the Long Valley intracrustal chamber, by ascent of a new intrusion from great depth, or by pressurization of aqueous fluid?

The authors have restudied the geologic and eruptive history of Long Valley Caldera and its periphery in far greater detail than previous work, remapping the area at 1:24,000 scale and (with our Menlo Park USGS colleague Andrew Calvert) radioisotopically dating nearly all eruptive units (Hildreth and others, 2014, 2017; Hildreth and Fierstein, 2016a, b). There has never been a non-rhyolitic eruption inside the structural caldera, and the most recent rhyolitic ones were $\sim 330 \mathrm{ka}$ in the southeast moat and $\sim 100 \mathrm{ka}$ in the west moat. There has been no eruption on the resurgent dome in 500,000 years. The numerous mafic eruptions peripheral to Mammoth Mountain began $\sim 230 \mathrm{ka}$, issuing from vents outside the caldera's structural margin.

From Glass Mountain to the caldera to the early rhyolite to Mammoth Mountain, there has been a southwestward migration of eruptive foci for the past 2 m.y. Vents for the successive episodes are clustered, not scattered randomly. It would be unprecedented for a new intrusion today to backtrack to the mid-caldera beneath the resurgent dome. Mantle-derived mafic magma (basalt or trachyandesite) has not erupted on the site of the caldera for more than 2.5 m.y. The domain of mantle productivity that energized crustal melting and rhyolitic magmatism for nearly $2 \mathrm{~m}$.y. withdrew southwestward from Long Valley a quarter-million years ago.

The caldera's west moat is contiguous with the active Mammoth system, and we infer that the thermal contributions of mantle-derived Mammoth basalts that have intruded into or near the caldera's ring-fault zone have been responsible for delaying crystallization of the Long Valley rhyolite beneath the west moat. Rhyolitic eruptions took place in the west moat at approximately $150,115,110,100$, and $0.6 \mathrm{ka}$ (Hildreth and Fierstein, 2016a). Elsewhere in the caldera, the final eruptions were at 360-330 ka, exclusively rhyolitic. In and near the ringfault zone contiguous with the west moat, Mammoth system eruptions of basaltic to trachyandesitic magma took place at about 230-220, 190-180, 175, 172, 165, 164, 154, 160-150, $131,125,101,90,85,66,33$, and $17 \mathrm{ka}$ (Hildreth and Fierstein, 2016a). As there has been no late Pleistocene (130-11 ka) magmatism of any kind anywhere else in the caldera, it seems a strong inference that the extracaldera mafic Mammoth magmatism (230 ka to the present) has sustained or reactivated pods of Long Valley rhyolitic crystal mush in the contiguous west moat (and only in the west moat).

The geochronologically calibrated geological and volcanological history and the weakness of gas emission, seismicity, 
and thermal signal beneath the major part of the Pleistocene resurgent dome make us skeptical that the recent uplift there is caused by magmatic intrusion. Instead, evidence and inferences are developed here that the pressure source for ongoing uplift is low-viscosity aqueous fluid ascending from the remainder of the once voluminous, now moribund, rhyolitic magma chamber - as its residue finally crystallizes completely to granite and expels its residual volatiles by "second boiling."

In the following paragraphs, we outline the basis of our skepticism, and we suggest alternative perspectives about the ongoing unrest.

\section{Seismicity in the Sierra Nevada directly south of Long} Valley Caldera. During the interval 1980-2015, there were $\sim 720$ earthquakes greater than $M 3$ within the caldera and $\sim 1,140$ greater than $M 3$ in the adjacent Sierran block - within an area similar in size to that of the caldera. Cumulative seismic moments for the 35-year interval were $2.4 \times 10^{18} \mathrm{~N}-\mathrm{m}$ in the caldera and $8.7 \times 10^{18} \mathrm{~N}-\mathrm{m}$ in the Sierra. There have thus been $\sim 1.6$ times more $M>3$ events in the Sierra and $\sim 3.6$ times more seismic energy released in the Sierra than in the adjacent caldera. If Sierran seismicity reflects regional tectonic stresses and if intracaldera seismicity is largely mediated by pressurized geothermal or magmatic fluids (Prejean and others, 2002; Shelly and others, 2016), then, as most of the Pleistocene resurgent structure is seismically quiescent, is it not obvious that the prime mover is the extracaldera tectonic stress field?

Major seismicity in the adjacent Sierra started in 1978 and has persisted ever since, more continuously than the recurrent swarms in the SMSZ. Four M6 earthquakes in May 1980, three of which were in the Sierra and the other in the ring-fault zone, marked the onset of recurrent seismic swarms along the SMSZ. We infer that the Sierran earthquakes reactivated the directly contiguous segment of the steeply dipping ring-fault zone (which had been there since $767 \mathrm{ka}$ ), initiating what soon became known as the SMSZ. It was only this short segment of the ring-fault zone, shaken by the adjacent Sierran seismicity and subject in common to the same regional tectonic stress field (Prejean et al., 2002; Hill, 2006) that became seismically active in 1980 , not the other $300^{\circ}$ of the aseismic ring-fault zone, the $75-\mathrm{km}$-long circumference of which encircles the equally aseismic resurgent uplift.

Cumulative uplift of $\sim 83 \mathrm{~cm}$ since 1980 has been centered in the south-central part of the Pleistocene resurgent structure, which had been upwarped at least $400 \mathrm{~m}$ by early postcaldera resurgence (nearly all of its relative uplift prior to $570 \mathrm{ka}$ ). The ongoing uplift has been punctuated by short pulses of more rapid rise in 1980, 1982, 1983, 1989-90, and 1997-98 (Hill and others, 2002) plus a weak resumption of uplift since 2011 (Montgomery-Brown and others, 2015). Setting aside the question of which may have triggered which, all the pulses of uplift have overlapped in time with extended episodes of seismicity in both the Sierra and the caldera (fig. 7 of Hill, 2006). In the Sierran block, most focal depths are $5-15 \mathrm{~km}$, and in the caldera mostly $2-10 \mathrm{~km}$. Much of the 1989 seismicity and some of that in 1997 took place under
Mammoth Mountain, which is also in the Sierra Nevada on granitic basement, not in the caldera.

If intracaldera uplift, inboard of the ring-fault zone, were really the prime mover, why does this recurrent linkage occur and why are most of the earthquakes and most of the seismic moment in the extracaldera Sierra Nevada block?

2. South Moat Seismic Zone. Within the caldera, a vast number of earthquakes occurs at depths of 2-10 km in the SMSZ (Prejean and others, 2002), which extends about $12 \mathrm{~km}$ along the caldera's ring-fault zone, bounded by the Pleistocene resurgent dome to the north and the large contiguous seismogenic domain in the Sierra Nevada to the south. The Sierran and SMSZ areas of dense seismicity are continuous, not spatially discrete. Around most of the ring-fault zone and beneath most of the resurgent dome, seismicity is negligible.

SMSZ seismicity encroaches slightly northward under the southernmost fringe of the elsewhere aseismic Pleistocene resurgent structure, which had been domed $\sim 400 \mathrm{~m}$ by $570 \mathrm{ka}$. The seismically active southern fringe of the old uplifted area is coincident with the strip where fumaroles are a manifestation of geothermal fluids. Fumaroles and earthquakes are jointly most concentrated in two lobes - around Fumarole Valley and around the site of Casa Diablo Hot Springs. The seismically active fringe continues along the southeast foot of the uplift as far as "Blue Chert" (fig. 10) and Little Hot Creek, likewise areas of fumaroles and hot springs. These southeastern features are inferred to overlie a deeply buried north-trending precaldera fault that has little or no postcaldera surface displacement.

The geothermal aquifer is not sourced in the SMSZ or beneath the uplift but, instead, flows eastward above the seismically active strip from sources in the caldera's west moat (Sorey and others, 1991; Suemnicht and others, 2006). At its east end, the SMSZ terminates where much of the geothermal fluid vents to the surface, near and beyond Hot Creek. At its west end, the SMSZ terminates just south of Mammoth Knolls, one of the youngest (100 ka) rhyolite extrusions sourced inside the structural caldera. The SMSZ and the seismic southern fringe of the uplift are thus coextensive beneath the thermal aquifer that originates in the west moat.

Although the aquifer itself flows through the $2-3-\mathrm{km}-$ thick caldera fill, high-resolution hypocenter locations (Prejean and others, 2002; Shelly and others, 2016) demonstrate dense seismicity below the aquifer that defines sets of faults that extend to depths of 8-9 km beneath the SMSZ and to $7.5 \mathrm{~km}$ beneath the "Blue Chert" area (fig. 10) at the southeast fringe of the Pleistocene structural uplift. Seismicity beneath the aquifer in the SMSZ is within the caldera's ring-fault zone and presumably extends down along what was the still deeper sidewall of the precollapse magma reservoir. The earthquake swarms that define the north-trending cryptic fault set near "Blue Chert" (Shelly and others, 2016) may coincide with a concealed northern segment of the Hilton Creek Fault that was beheaded by caldera collapse. All the intracaldera seismicity involves migrating earthquake swarms that are thought to be 
activated by elevated fluid-pressure transients caused by rapid upward diffusion of low-viscosity aqueous fluid. The geothermally exploited aquifer is itself shallow, but the whole SMSZ appears to be underlain by pressurized aqueous fluids that pervasively ascend into the brittle crust from depths of at least $10 \mathrm{~km}$.

A source of such ascending fluid could be "second boiling" of the crystallizing residue of the former Long Valley rhyolitic magma reservoir at depths of $10 \mathrm{~km}$ or more, representing final expulsion of (dominantly aqueous, $\mathrm{CO}_{2}$-poor) volatile components as the moribund rhyolite solidifies to granite.

Neither the distribution of SMSZ earthquakes nor their focal mechanisms are consistent with the quasi-circular radial symmetry of the ongoing uplift recorded by geodetic data (Montgomery-Brown and others, 2015). Prejean and others (2002) concluded that the stresses promoting intracaldera inflation hardly affect the regional tectonic stress field that dominates the SMSZ seismicity. Moreover, inflation of the uplift could be expected to impart stresses that would impede the dextral slip inferred by Prejean and others (2002) along the SMSZ. If seismicity in both the Sierra and the SMSZ reflects regional tectonic stresses (as concluded by Prejean and others, 2002), and if SMSZ seismicity is mediated and modulated by pressurized geothermal fluids (Hill, 2006; Shelly and others, 2016), then, as most of the Pleistocene resurgent structure (and indeed most of the rest of the caldera) is seismically quiescent, is not the prime mover clearly the regional tectonic stress field?

We infer that Sierran earthquakes reactivated the directly contiguous segment of the steeply dipping ring-fault zone (which had been there since $767 \mathrm{ka}$ ), initiating what became known as the SMSZ. It was only this short segment of the ring-fault zone, shaken by the adjacent Sierran seismicity and subject in common to the same regional tectonic stressfield (Prejean and others, 2002; Hill, 2006) that became seismically active in 1980 , not the other $300^{\circ}$ of the aseismic ring-fault zone, the 75-km-long circumference of which encircles the equally aseismic resurgent uplift.

Earthquakes are rare beneath most of the resurgent structure as well as on its west, north, and northeast flanks, where geothermal fluids are unknown and, if present, have no surface manifestations. Beneath most of the Pleistocene resurgent uplift, there is no elevated heat flow (in many deep wells) and very little seismicity. Why would an ongoing intrusion under the old cold resurgent structure, as advocated by some, not be accompanied by earthquakes? Absence of brittle failure around the modeled inflation source (fig. 4 of MontgomeryBrown and others, 2015) seems more consistent with poroelastic fluid pressurization than with injection of magma.

\section{Resurgent dome: normal heat flow and low seismic-}

ity. Nearly all deep drillholes (shown in fig. 10) on or around the Pleistocene resurgent structure have thermal profiles that show reversals with depth, near-normal geothermal gradients beneath the reversals, and/or large isothermal segments at their bottoms (Sorey and others, 1991; Farrar and others, 2003;
Hurwitz and others, 2010). The Long Valley Exploratory Well (LVEW), centered on the resurgent uplift, displays a constant temperature of $\sim 100{ }^{\circ} \mathrm{C}$ from a depth of 2,000 $\mathrm{m}$ to its bottom at nearly $3,000 \mathrm{~m}$. At the Casa Diablo geothermal plant, well M-1 showed a sharp reversal beneath the geothermal aquifer, thus yielding a temperature of only $\sim 100^{\circ} \mathrm{C}$ at its $1,605-\mathrm{m}$ total depth. Well CP, at the eastern foot of the resurgent area, had a bottom-hole temperature of $148^{\circ} \mathrm{C}$ at a depth of 1,847 m. Well 13-26, at the southeastern foot of the resurgent area, had a bottom-hole temperature of $110^{\circ} \mathrm{C}$ at a depth of 1,186 m, and well 13-21, just north of Fumarole Valley, had $99^{\circ} \mathrm{C}$ at $1,111 \mathrm{~m}$. Three more wells on the west wall of Fumarole Valley have bottom-hole temperatures of 123$129^{\circ} \mathrm{C}$ at depths of $327-607 \mathrm{~m}$; their fluids were inferred by Hurwitz and others (2010) to reflect lateral hydrothermal flow eastward through the southern fringe of the resurgent uplift, from the caldera's west moat via Casa Diablo. They concluded that the modest temperatures, the deep isothermal segments, and the contrast of the warm seismic southern fringe of the resurgent structure with its cold aseismic major part are not consistent with the presence of upper-crustal magma beneath it.

Before drilling of LVEW demonstrated $100{ }^{\circ} \mathrm{C}$ isothermal conditions at depths of $2-3 \mathrm{~km}$, the rarity of earthquakes beneath most of the resurgent structure had been interpreted to suggest that the brittle-ductile transition could be as shallow as $5 \mathrm{~km}$ beneath the uplift, whereas seismicity nearby extends to depths of $10 \mathrm{~km}$ or more beneath the SMSZ (Hill, 1992). Just as likely, the brittle-ductile transition is even deeper than $10 \mathrm{~km}$ beneath the uplift, and there is simply no significant seismicity there at any depth. Moreover, aseismicity seems incompatible with ongoing magmatic intrusion, which is likely to be guided as dikes by upper-crustal fractures, steeply dipping strata, and extensional tectonic stress. If the pressure source were, however, enclosed within a thick ductile or viscoelastic envelope, would this be consistent with an uplift footprint that extends $10 \mathrm{~km}$ outside the caldera (figs. 7-10 of Savage and others, 1987)?

In defending a model of magmatic intrusion at depths of $6-8 \mathrm{~km}$ to account for the $\sim 83 \mathrm{~cm}$ of uplift since 1980 , proponents appeal to the slow rate of thermal conduction to explain the absence of a tell-tale thermal signal at depths of 1-3 km. How defensible, however, is appeal to purely conductive heat flow in an area semi-encircled by a fringe of manifestly vigorous convective heat flow? Heat transport is not merely lateral in the shallow geothermal aquifer but by fluids ascending steeply from depths at least as great as $10 \mathrm{~km}$ (Prejean and others, 2002; Shelly and others, 2016).

Hurwitz and others (2007) modelled conditions under which the poroelastic response to increasing fluid pressure and accompanying thermoelastic rock expansion could promote intracaldera uplift. They further noted that, under such conditions, either a dwindling of fluid ascent or an abrupt increase in permeability by hydrofracturing could induce subsidence, as recorded at other calderas. An episode of modest subsidence was indeed recorded at Long Valley 
in 1998-2002 (Langbein, 2003). The absence, so far, of larger subsidence episodes might be related to (1) the restricted, unilaterally southward, fluid-escape path; (2) an extended episode of recent fluid ascent from the large plutonic reservoir; or (3) the weakness of upper-crustal hydrothermal circulation beneath most of the uplift, in contrast to calderas at Yellowstone and Campi Flegrei where vigorous system-wide convection hastens cooling and subsidence.

4. Resurgence, magmatism, and ascending fluid. Intracaldera Bishop Tuff, more than 1,000 m thick beneath the uplift, was domed $>400 \mathrm{~m}$ upward, largely by intrusion of early rhyolite sills or laccoliths into the ignimbrite (McConnell and others, 1995 ) by the end of the early rhyolite episode (750-640 ka). Ice-rafted erratics from the Sierra Nevada were dropped or beached on 700-ka early rhyolite lavas and later raised $>250 \mathrm{~m}$ above nearby highstand shorelines of the caldera lake, confirming that most of the resurgent uplift took place in early postcaldera time (Hildreth and Fierstein, 2016b). The north slope of the resurgent uplift was already steep before a 570-ka moat rhyolite lava flow poured down it into the north moat.

Nonetheless, lesser amounts of uplift did take place later, probably episodically. Where it impinges on the resurgent structure, the northwest margin of the 333-ka Hot Creek rhyolite coulee was bent upward by $\sim 40 \mathrm{~m}$ (Hildreth and Fierstein, 2016a, b). Several mafic lavas $\left({ }^{40} \mathrm{Ar} /{ }^{39} \mathrm{Ar}\right.$-dated from $180 \mathrm{ka}$ to $125 \mathrm{ka}$ ) that flowed eastward from vents in or near the west moat are cut by graben faults that cross the uplift, but the vertical displacements are limited to only 10-30 m (Hildreth and Fierstein, 2016a); the faulting nonetheless indicates that intermittent increments of lesser uplift continued into the late Pleistocene, long after the final eruptions on or near the resurgent dome. After $500 \mathrm{ka}$, volcanism was limited to moats peripheral to the uplift, and nothing more erupted through the resurgent dome. The dome structure is older than $570 \mathrm{ka}$, but small increments of uplift, unrelated to eruption, have persisted intermittently.

The $\sim 83 \mathrm{~cm}$ of cumulative episodic uplift since 1980 probably likewise represents incremental structural accentuation of the longstanding domical flexure by pressurization from below, rather than a wholly new bending of the roof plate. Ongoing ascent of low-viscosity aqueous fluid sourced as deep as $10 \mathrm{~km}$ around the southern fringe of the uplift has been invoked to explain the consistently upward-propagating earthquake swarms in the SMSZ (Prejean and others, 2002; Shelly and others, 2016). The ascending fluid may also provide the principal pressure source centered beneath the Pleistocene uplift itself, whence some of the fluid escapes laterally to the SMSZ, there triggering and mediating the ascending swarms of earthquakes.

Collapse of the 25-km-wide Long Valley Caldera implies the presence at $767 \mathrm{ka}$ of a pluton-scale magma reservoir. That most of the $650 \mathrm{~km}^{3}$ of high-silica rhyolitic magma that erupted was crystal-poor implies that it was melt extracted from a granitic crystal-mush residue at least an order of magnitude larger. Subsequent extraction of $100 \mathrm{~km}^{3}$ of crystal-poor rhyolite melt as the early rhyolite (750-640 ka) and $\sim 2 \mathrm{~km}^{3}$ more melt as the Hot Creek flow and its satellites (360-330 ka) should further have depleted the crystallizing pluton. With no evidence in 500,000 years for mafic thermal replenishment (except adjacent to the west moat), it can be inferred that the Long Valley pluton progressed from crystal mush to a substantially solid body of granite. Exsolution and upward expulsion of $\mathrm{CO}_{2}$-poor aqueous fluid by second boiling of the granitic residue probably sustained recurrent episodes of minor roof-plate deformation throughout the late Pleistocene, continuing to the present.

The model of fluid-driven uplift requires that the updomed cauldron block (roof plate), most of which is aseismic, low in temperature, and devoid of fluid emissions, should be relatively impermeable, ductile at depth, and thick. Because most of the confining ring-fault zone is also aseismic and emission-free, it is inferred to be sealed and thus likewise impermeable, leaving ascending fluid no egress save the 12-km-long segment along the SMSZ.

Scrutiny of the 3-km-deep LVEW core by McConnell and others $(1995,1997)$ showed most components of the roof plate to be of low permeability. The Bishop Tuff is densely welded, devitrified, contains chlorite, pyrite, and pervasive calcite, with a dense groundmass mosaic of secondary quartz, clay minerals, and calcite. Intruding the Bishop Tuff are 10 sills of fine-grained aphanitic early rhyolite, the stack of which would alone provide an impermeable barrier. The thickest of the sills are 106, 43, 40, and $17 \mathrm{~m}$ thick, and their cumulative thickness is $330 \mathrm{~m}$. They are densely microcrystalline and argillized, containing illite, mixed-layer illite-smectite, and pervasive calcite and secondary quartz. The basement rocks include chlorite- and epidote-bearing metavolcanic rocks but are predominantly fine-grained laminated silicic and pelitic hornfels with subordinate quartzite and marble interbeds. Fractures are filled with quartz, calcite, pyrite, chlorite, epidote, and pervasive clay minerals. Most lithologies in the aseismic cauldron block are thus finegrained, non-granitic, dense, and dry. Low permeability of a thick roof plate is consistent with diversion of the pressurizing fluid toward the SMSZ from depths of 8-10 km.

\section{Structure of the Pleistocene resurgent uplift. At least} $400 \mathrm{~m}$ of total uplift of the resurgent dome was largely accomplished before $570 \mathrm{ka}$. No radial or concentric faults, as might be associated with domical uplift, are present. The fault system is dominated by north-northwest trends nearly parallel to those of rangefront faults north and south of the caldera and also parallel to the strike of steeply dipping structures and bedding in metamorphic basement rocks that make up most of the subsided caldera floor. The two grabens, Fumarole Valley and Smokey Bear Flat, are neither medial nor apical (as so often recited) but, instead, transect flanks of the uplifted region. The pattern of faults on the uplift is more congruous with Basin and Range extension than with the radially symmetrical ongoing inflation. 
In the context of the extensional tectonic regime and steeply bedded basement stratigraphy, one would expect an upper-crustal intrusion to be tabular. The radial symmetry of the ongoing uplift thus suggests that there is no such intrusion. Crystallizing rhyolite has long been present beneath Long Valley, as shallow as $5 \mathrm{~km}$ in precaldera time but by today probably stagnant and deeper than $10 \mathrm{~km}$. Highly crystalline rhyolitic magma is unlikely to ascend. More likely, the crystallizing residue eventually locked up into a rigid framework (fig. 18 of Hildreth and Wilson, 2007). Release of its remaining aqueous fluid by second boiling, however, is inevitable.

Although the resurgent uplift is roughly circular in plan view, it is structurally complex, and to think of it as a simple dome may prejudice interpretation of the recent unrest. The resurgent structure is more like the opposing pair of bulkhead doors on an elongate storm cellar. Grossly, the opposing limbs dip west-southwest and east-northeast, with multi-block complexity along both downset grabens. The total uplift since 1980 amounts to $\sim 0.2$ percent of the middle Pleistocene resurgent uplift. Unrest and resurgence are not the same.

6. Area of the current uplift. Since 1980, cumulative uplift of $\sim 83 \mathrm{~cm}$ has taken place in several episodes and was measured by a sequence of levelling, trilateration, EDM, GPS, and InSAR. Attention has been concentrated on the Pleistocene resurgent dome, an area $10 \mathrm{~km}$ in diameter, near the southcenter of which the recent uplift has been greatest (Savage and others, 1987; Langbein, 2003; Montgomery-Brown and others, 2015). The geodetic studies, however, describe a roughly symmetrical area of domical upwarping more than $30 \mathrm{~km}$ in diameter that extends far beyond the Pleistocene uplift and even well outside the caldera. Along Highway 395, 5-10 cm of the uplift extends as far northwest as June Lake Junction (10 km outside the caldera) and as far southeast as the Hilton Creek Fault ( $\sim 2 \mathrm{~km}$ outside the buried structural boundary of the caldera) (fig 4 of Savage and Lisowski, 1984; figs. 7-10 of Savage and others, 1987).

Rather than just bending the caldera's roof plate, the deformation impacts a region well outside the ring faults. If the regional tectonic stressfield is important in driving the uplift, why is the ongoing uplift radially symmetrical? On the other hand, if uplift broader than the caldera itself were caused by subcaldera processes alone, why are there no earthquakes along most of the ring-fault zone? Must one not infer that the ring-fault zone remains stably sealed everywhere except along its short south-moat segment where it has been reactivated adjacent to the seismically dynamic Sierran block? If radial symmetry of the recent uplift reflects a radially symmetrical pressure source, is it not more likely to represent a diffusive domain of excess fluid pore pressure rather than a magmatic intrusion, which might be guided by the steep bedding, numerous steep faults, and extensional stress field in the upper crust?

\section{Absence of $\mathrm{CO}_{2}$ flux beneath the area of ongoing uplift.} Following the 1989 earthquake swarm under Mammoth Mountain, onset of tree-killing magmatic $\mathrm{CO}_{2}$ emissions took place within 5-16 months (Cook and others, 2001). A deep swarm below Mammoth Mountain in 2009 was followed within one year by a doubling of $\mathrm{CO}_{2}$ emissions at the Horseshoe Lake tree-kill area (Lewicki and others, 2014). Werner and others (2014) pointed out that yet another pulse of $\mathrm{CO}_{2}$ emissions had taken place in 2000-2001, subsequent to Mammoth Mountain seismicity that had peaked in November 1997 , so within $\sim 3$ years. Total $\mathrm{CO}_{2}$ emission at Mammoth Mountain was estimated to be 1,200-1,300 metric tons/day (t/d) in the early 1990s (Farrar and others, 1995); $250 \mathrm{t} / \mathrm{d}$ in 1998 (Gerlach and others, 1999); 416 t/d in 2011 (Werner and others, 2014); and $311 \mathrm{t} / \mathrm{d}$ in 2013 (Lewicki and others, 2014). In contrast, total $\mathrm{CO}_{2}$ emissions for 13 tree-kill and bare-ground sites along the hydrothermally active south-flank fringe of the resurgent uplift was merely $8.7 \mathrm{t} / \mathrm{d}$ in 2003-2004 (Bergfeld and others, 2006). These authors concluded (a) that so weak a flux of $\mathrm{CO}_{2}$ was easily provided by the shallow geothermal aquifer (sourced in the west moat), (b) that there is virtually no $\mathrm{CO}_{2}$ emission along the south moat proper or from the main part of the resurgent uplift, and (c) that there is no evidence for input of magma or magmatic fluids beneath the caldera. Moreover, a carbon-isotope study of soil gas (Lucic and others, 2015) showed that the weak soil $\mathrm{CO}_{2}$ above the geothermal aquifer is of magmatic-hydrothermal origin (from the west moat) but that the meager soil $\mathrm{CO}_{2}$ along much of the south moat, elsewhere around the caldera floor, and on most of the resurgent uplift is predominantly biogenic.

If $\mathrm{CO}_{2}$ emission responds to seismic swarms under Mammoth Mountain within a year or two, why has there been no emission of magmatic $\mathrm{CO}_{2}$ on the resurgent structure in the 37 years since measured uplift started around 1980 - if the uplift were truly promoted by upper-crustal intrusion of new magma? There are numerous faults across and around the resurgent dome and steeply dipping bedding in the subsided roof plate beneath it that could have facilitated ascent of $\mathrm{CO}_{2}-$ had it actually been released into the subcaldera crust. The lack of $\mathrm{CO}_{2}$ emission essentially precludes mantle-derived mafic (or intermediate) magma as a pressure source for the ongoing uplift.

No magmatic gas, modest heat flow, and no seismicity compels the inference that there is no new magma beneath the area of uplift. Not all bulges are what they appear to be. If not a new intrusion, the most plausible and compelling alternative physical model is aqueous fluid being released by late-stage solidification and second boiling of Long Valley's formerly capacious rhyolite reservoir.

8. Helium emissions. Suemnicht and others (2015) summarized abundant He-isotope data for fumaroles, hot springs, and geothermal fluids across the caldera. They noted the absence of high-temperature fumaroles, absence of elevated $\mathrm{CO}_{2}$, $\mathrm{SO}_{2}$, and halogens, and general lack of magmatic signatures in Long Valley fluids. Values of ${ }^{3} \mathrm{He} /{ }^{4} \mathrm{He}$ around the resurgent dome are 2.7-4.9 $\mathrm{R}_{\mathrm{A}}$, but values in the range 4.5-6.1 are present farther east at Hot Creek and Little Hot Creek. They suggested that the higher values distal to the hydrothermal aquifer might reflect mantle contributions rising along strands of the 
buried (precaldera) Hilton Creek fault zone. For central and southern parts of the caldera, however, including the SMSZ and the resurgent structure, they concluded that modest heat flow and negligible magmatic signatures in the fluids weigh strongly against any new injection of magma into the crust.

At Mammoth Mountain, however, the association of seismic swarms, mid-crustal LP earthquakes, elevated $\mathrm{CO}_{2}$ emissions, and episodes during which ${ }^{3} \mathrm{He} /{ }^{4} \mathrm{He}$ has risen to values as high as $6.7 \mathrm{R}_{\mathrm{A}}$ implicates intracrustal ascent and degassing of basalt (Sorey and others, 1993; Shelly and Hill, 2011). The lack of such associations accompanying the SMSZ swarms and lack of any such signals at all beneath the resurgent dome is strong evidence against recent subcaldera intrusion of basalt or release of gas therefrom.

9. The Hilton Creek Fault strikes N. $20^{\circ}$ W. along the east side of the seismically active Sierran block, which forms the south wall of the caldera. The down-to-the-east normal fault, inferred to have been active since early Quaternary time, controls a great scarp with $\sim 1,100 \mathrm{~m}$ relief that provides an eastern free face for the Sierran block. Although it produced $\sim 17 \mathrm{~m}$ of postglacial normal displacement on MIS-2 moraines at McGee Creek, the Hilton Creek Fault has not been seismically active during any of the 1980-2016 earthquake episodes nearby. Within the Sierran block, belts of diffuse seismicity have been recurrently active (Hill and others, 2002), and highresolution relocations have associated these belts with several cryptic fault zones within the block (Prejean and others, 2002; Hill, 2006). Focal mechanisms indicate sinistral slip for the cryptic Sierran faults but dextral slip for those in the SMSZ. Two of the sinistral Sierran faults strike into the Hilton Creek Fault obliquely, and a third (dextral SNB4 of Prejean and others, 2002) crosscuts and terminates the reach of the beheaded Hilton Creek Fault that remained active in postcaldera time south of the caldera. Although the Hilton Creek Fault has commonly been depicted as continuing into the caldera, there is no evidence of postcaldera slip north of its apparent truncation by the cryptic fault SNB4 (fig. 6 of Prejean and others, 2002), which coincides here with the ring-fault zone.

Several of the cryptic faults in the south moat share with extracaldera fault SNB4 dextral focal-plane solutions, west-northwest strikes, and steep north-northeast dips (table 2 of Prejean and others, 2002). Moreover, only a 3-km-wide gap, covered by till and alluvium, separates SNB4 from the apparent end of the great Round Valley Fault, which also locally strikes west-northwest and has a large dextral component to its major transtensional displacement (Hildreth and Fierstein, 2016b; Phillips and Majkowski, 2011). That the dextral component is currently being extended from the Round Valley Fault into the caldera's south moat is further evidence of the dominance of regional tectonic stress on intracaldera seismicity.

The SMSZ, along which dextral focal-plane solutions predominate (Prejean and others, 2002), has been called a "leaky transform fault" by Hill and Montgomery-Brown (2015). However, there have been no "leaks" (eruptions) along the south moat since the Hot Creek flow at $333 \mathrm{ka}$. Moreover, although the ring-fault zone has been there since $767 \mathrm{ka}$, no surface displacements are recognized. The south moat is floored by several mafic lava flows, all of which yield ${ }^{40} \mathrm{Ar} /{ }^{39} \mathrm{Ar}$ ages between 180 and $92 \mathrm{ka}$ (Hildreth and others, 2014), but none of them is faulted, dextrally or otherwise, within the SMSZ (Hildreth and Fierstein, 2016a). The cryptic dextral faults modeled by Prejean and others (2002) may be of very recent origin, perhaps as young as 1980 .

None of the cryptic faults, seismically relocated in either the Sierra or the caldera, is known to have surface expression, so all may be of relatively recent origin. How can the dominant seismicity in the area, including at least 12 events of M5.0-M6.1 (Prejean and others, 2002), located only 0-8 km west of the Hilton Creek Fault, take place without activating that great free-standing block-bounding fault itself? Why should east-northeast/west-southwest extension induce sinistral slip within the Sierran block (as a complement to dextral slip in the SMSZ) rather than reactivating normal slip on the adjacent Hilton Creek Fault?

10. Four belts of seismicity ("limbs" of Hill, 2006), relocated as fault zones in the Sierran block by Prejean and others (2002), have the following strikes and dips: (a) $359^{\circ}$ at $64^{\circ} \mathrm{E}$, $12-\mathrm{km}$ long and forming the western boundary of abundant Sierran seismicity; (b) $21^{\circ}$ at vertical, $9 \mathrm{~km}$ long, sinistral; (c) $26^{\circ}$ at vertical, $5.6 \mathrm{~km}$ long, sinistral; and (d) $298^{\circ}$ at $60^{\circ} \mathrm{NE}$., $5 \mathrm{~km}$ long, dextral. These seismic belts crosscut at high angles the structure of the Mount Morrison pendant, in which the Paleozoic strata strike roughly $330^{\circ}$ and are typically disposed near the vertical (dipping 50 $50^{\circ}-90^{\circ}$; Rinehart and Ross, 1965; Greene and Stevens, 2002). The Sierran seismicity extends from near the surface to depths of $12-15 \mathrm{~km}$ (deeper than in the SMSZ), depths at which the steeply dipping pendant (or septum) strata may (or may not) be rooted in more massive plutonic rocks. Nonetheless, is it not remarkable that the several arrays of Sierran-block earthquakes are completely unaffected by the north-northwest regional trend of the steeply dipping basement strata? Or by the north-northwest trend of the main rangefront faults near Long Valley?

11. Published models of sources of ongoing uplift. Several source models have been proposed to account for the recent deformation at Long Valley, nearly all assuming magmatic intrusion beneath the resurgent dome. Geodetic models have included plutons, sills, point sources, spherical bodies, and prolate ellipsoids - pipelike or squat, single or paired, vertical or inclined, deep or shallow, and with or without a viscoelastic shell.

Deformation data through 1985 were modelled as the product of two Mogi point sources of inflation at depths of 5 and $10 \mathrm{~km}$ beneath the resurgent dome, spaced $\sim 5 \mathrm{~km}$ apart laterally, along with dextral slip in the south moat (Langbein and others, 1987; Langbein, 1989). Renewed uplift in 19891991 was attributed to a single Mogi point source centered beneath the resurgent dome at $6-8 \mathrm{~km}$ depth, with little contribution from other sources; a revised model was said to account 
for most of the deformation accumulated since 1979 (Langbein and others, 1993). Completion of a new levelling survey in 1992 and its combination with extensive trilateration data led to another new model that replaced spherical point source models with a pair of prolate ellipsoidal sources - one as shallow as $5.5 \mathrm{~km}$ beneath the resurgent dome and another (less well defined) said to plunge northeast at 10-20 km beneath the south moat (Langbein and others, 1995). Renewed inflation in 1997-1999 led Langbein (2003) to minor modifications - a near-vertical prolate spheroid as the principal pressure source under the resurgent dome at 6-7 km depth, dextral slip in the south moat, and a mid-crustal inflation source at $12-20 \mathrm{~km}$ beneath the south moat. Analysis of InSAR data, however, led Thatcher and Massonnet (1997) and Fialko and others (2001) to model only a single pressure source (under the resurgent dome); the latter study favored a prolate spheroid at a depth of $7.2 \mathrm{~km}$. Using the EDM and levelling data for the 1988-1992 interval, on the other hand, Tiampo and others (2000) compared spherical Mogi and prolate spheroidal models for two inferred pressure sources - a larger one at 9-10 km beneath the resurgent dome and a lesser one at 7-12 $\mathrm{km}$ beneath the south moat. Battaglia and others (2003a) combined GPS data with levelling and EDM measurements to model a pressure source beneath the resurgent dome as a vertically elongate prolate spheroid with an aspect ratio between 0.25 and 0.65 , at a depth between 4.9 and $7.5 \mathrm{~km}$, and representing a volume change between 0.06 and $0.13 \mathrm{~km}^{3}$. Clearly, none of these models is unique.

Nearly all models assumed the upper crust to behave as a homogeneous, isotropic, purely elastic solid, which it obviously is not. The $2-3 \mathrm{~km}$ of postcaldera fill consists of subhorizontally disposed strata, broadly arched and faulted by middle Pleistocene resurgence, that range in lithology (and thus widely in density) from lake silt to tuff to rhyolite to basalt. In contrast, the subsided roof plate consists of subvertical Paleozoic metasedimentary strata intruded locally by subordinate bodies of granodiorite. Such steeply dipping strata probably also underlie whatever crystalline residue remains of the Bishop Tuff and early rhyolite magma body. If a recent upper-crustal intrusion were indeed the pressure source for intracaldera uplift, its shape is likely to have been influenced by its host-rock layering, whether horizontal, vertical, or otherwise. If emplaced within the steeply dipping basement strata of the roof plate at 2-8 km depths, such a conjectured intrusion could be expected to be steeply tabular and to strike north-northwest.

Newman and others (2006) did not consider the host-rock structure, but they avoided the elastic approximation by modelling a vertical prolate spheroid at $6 \mathrm{~km}$ depth encased within a viscoelastic shell $0.5-1 \mathrm{~km}$ thick. This, they argued, would increase the effective volume of the pressure source, would greatly lower the pressure needed for a given surface deformation, and would sustain uplift well after the peak pressure episode had passed. They were thinking in terms of a magmatic intrusion, but their scenario seems equally applicable to ascending pulses of slowly dispersing near-solidus granitederived aqueous pore fluid.

Source models that combine microgravity data for Long Valley with the varied geodetic measurements were pioneered by Battaglia and others (1999). For the interval 1982-1998, they measured decreases in gravity throughout the caldera that were as great as $-107 \pm 6 \mu \mathrm{Gal}$ over the resurgent dome. After trying to correct for uplift and loosely estimated watertable fluctuations, residual gravity changes were calculated to be positive at most stations and as great as $+64 \pm 15 \mu \mathrm{Gal}$ locally on the resurgent dome. Assuming a point-source intrusion, they estimated a depth of 10.0-13.8 km, mass increase of $7.4 \times 10^{11} \mathrm{~kg}$, and volume increase of $0.16-0.32 \mathrm{~km}^{3}$, from which they calculated the density of the intrusion to be in the range $2,700-4,100 \mathrm{~kg} / \mathrm{m}^{3}$, leading them to infer a basaltic intrusion. This is inconsistent with lack of $\mathrm{CO}_{2}$ and $\mathrm{He}$ signals, as discussed above.

Accumulating geodetic data and an expanded microgravity survey in 1999 led Battaglia and others (2003a, b) to revise their model. They next proposed a vertically prolate spheroidal intrusion with an aspect ratio of 0.475 at a depth of 4.9-7.5 km under the resurgent dome, where its volume was estimated to be $0.105-0.187 \mathrm{~km}^{3}$ and its density in the range $1,180-2,330 \mathrm{~kg} / \mathrm{m}^{3}$, leading them to infer a hybrid magma+fluid intrusive mass. Using much the same data, Battaglia and Vasco (2006) explored a more general threedimensional distribution of inflation, estimating fractional volume changes in $\sim 5,000$ grid blocks beneath the resurgent dome. The exercise calculated a principal inflation volume at 5-7 km depth, elongate west-to-east, extending for $10 \mathrm{~km}$ beneath the southern third of the resurgent dome. A secondary inflation volume, $2.5 \times 3.5 \mathrm{~km}$ across but likewise 5-7 km deep, was modeled beneath Gilbert Peak, centered $\sim 6 \mathrm{~km}$ north of the first.

Using the same 1982-1999 microgravity data, Tizzani and others (2009) added 1992-2000 InSAR imagery and EDM data for many baselines to propose a revised model of the intrusive source, the geometry of which they assumed had not changed over the two decades concerned. They then modelled a prolate spheroid with an aspect ratio of $0.56-0.84$ that plunges $30^{\circ}-77^{\circ} \mathrm{SW}$. at a depth of $6.6-8.7 \mathrm{~km}$, and they recalculated its density to lie in the range $2,192-3,564 \mathrm{~kg} / \mathrm{m}^{3}$. The volume change was said to be $0.682 \mathrm{~km}^{3}$, which is four to seven times greater than the earlier estimates that used the same gravity data.

This summary should make obvious that the gravity inversions are far from unique and that estimates of depth, volume, density, and shape of any inferred intrusive source are highly uncertain and overinterpreted. Scrutiny of the residual gravity pattern (figure 4B of Tizzani and others, 2009) reveals extremely erratic distribution. The peak amplitude of the change in residual gravity (on the east side of the resurgent dome), $66 \pm 11 \mu \mathrm{Gal}$, is matched by values of $64 \pm 20 \mu \mathrm{Gal}$ outside the resurgent dome to the northwest and $63 \pm 33 \mu \mathrm{Gal}$ in the lowland near the airport. Another outboard station, on undeformed lakebeds northeast of the Hot Creek 
flow, gives $52 \pm 22 \mu \mathrm{Gal}$, another positive residual gravity change where there is no uplift. Moreover, within the western half of the resurgent dome, one station actually shows a decrease in residual gravity at $-3 \pm 22 \mu \mathrm{Gal}$. The erratic gravity pattern may in part reflect large uncertainties in water-table fluctuations, in statistical interpolation of free-air corrections, and in porosity and density variations in lithologically complex sections underlying the gravity stations. In any case, the adjusted residual data (figure 4B of Tizzani and others, 2009) were severely cherry-picked to arrive at the model advanced.

Contrary to the assertion by Tizzani and others (2009) that magma is "unambiguously" the cause of Long Valley unrest, the weakness of the gravity models shows that the material nature of the inflation source and the very existence of an intrusive body remain unproven.

\section{Disparity between modeled pressure source and} its volume increase. A recent comprehensive model of the location and dimensions of the inflation source (Montgomery-Brown and others, 2015) appears to fit all the relevant geodetic data. They favored a vertical ellipsoid $\sim 6 \mathrm{~km}$ high and $3.5 \mathrm{~km}$ in diameter with its centroid at a depth of $7.2 \mathrm{~km}$, dimensions that yield a volume of $\sim 38 \mathrm{~km}^{3}$. They reasoned that the same pressure-source domain had been the host for the entire series of discrete inflation events since 1980. The volume increase for the 2011-2014 uplift increment was calculated to be $\sim 0.023 \mathrm{~km}^{3}$. The model thus suggests that the material introduced (or expanding in place) occupied only 0.06 percent of the ellipsoid volume. Similar, if less extreme, mismatches attend previously published estimates of pressure sources for uplift since 1980. They acknowledged that the northern two-thirds of the caldera, which remains aseismic, is subject to the same inflation stresses as the SMSZ, which is clearly affected by both pore-pressure transients and regional tectonic stresses. Their model for the location and dimensions of the inflation source is well constrained, but what substance provides the volume increments?

Their analysis suggests that the centroid and the ellipsoid as a whole has been stationary, showing no evidence of ascent during the decades of geodetic measurements and modeling. The radial symmetry of the ongoing uplift is thought to be inconsistent with intrusion of a tabular dike or sill. The modeled ellipsoid may never have been an ascending body at all, but, instead, a porous or fractured domain suffused with fluid ascending from the secularly crystallizing Long Valley pluton below. Expansion of a distributed mobile interstitial phase would pressurize the ellipsoid from within. The very small volume fraction within the $38-\mathrm{km}^{3}$ inflating domain modeled is more consistent with introduction and poroelastic expansion of low-viscosity fluid - either interstitial or within a distributed fracture network - than with a tiny fraction of interstitial rhyolitic melt. The most reasonable geologic agent is low- $\mathrm{CO}_{2}$ aqueous fluid expelled from ultimate crystallization of the granitic residue of the formerly great Long Valley rhyolitic reservoir, by second boiling.

\section{Tomographic images of the moribund granitic residue?} Renewed tomographic searches for magma beneath the caldera were published by Seccia and others (2011) and Lin (2015). The former team inferred a low-velocity volume $\sim 20 \mathrm{~km}$ wide and 8-14 km deep, underlying much of the caldera. On the basis of $V p$ reduction of $\sim 5$ percent and greater $V s$ reduction, they speculated that the anomalous region might contain abundant partial melt, but Lin's (2015) results conflict with that suggestion. She found the anomalous domain of Seccia and others (2011) to have low $V p / V s$ values, "inconsistent with the presence of partial melt" (Lin, 2015, p. 28). The deep low- $V p / V s$ region may instead represent pressurized gas-bearing rock with high fluid compressibility.

The rhyolitic magma body that released $100 \mathrm{~km}^{3}$ of early rhyolite and last erupted in mid-caldera $\sim 330$ ka should by now, with no apparent basaltic thermal sustenance, have reached an advanced stage of crystallization, solidifying into a granitic pluton. Although at least 20 tomographic experiments have been undertaken at Long Valley, no magma body has ever been convincingly imaged. The caldera-wide low-velocity domain at $8-14 \mathrm{~km}$ depth imaged by Seccia and others (2011) and Lin (2015), however, is what the magmatic history of Long Valley would predict for the present-day moribund plutonic residue and its superjacent fluid halo.

After completion of this guide's text, a journal article was published that examines in detail the ongoing geophysical unrest and "puzzles" (Hildreth, 2017).

\section{Acknowledgments}

We are grateful to Bernard Chouet, Phil Dawson, Bill Ellsworth, Dave Hill, Shaul Hurwitz, Emily Montgomery-Brown, and Stephanie Prejean for helping us grapple with the geophysical puzzles. The geochronological contributions of Andy Calvert, and of Brent Dalrymple and Marvin Lanphere before him, have been essential to working out the region's volcanic history. Geologists always benefit from the fieldwork of those who have gone before. At Long Valley, admirable contributions were made by Roy Bailey, John Eichelberger, Bill Evans, Chris Farrar, Charles M. Gilbert, King Huber, Steve Lipshie, Gail Mahood, Larry Mastin, Vicki McConnell, Jenny Metz, Bill Putnam, Dean Rinehart, Don Ross, Mike Sheridan, Mike Sorey, Gene Suemnicht, and Colin Wilson. Thanks to David Fierstein, Juliet Ryan-Davis, and Mae Marcaida for help with the illustrations. The hospitality and companionship of Sally and Bob Drake of Old Mammoth have been a mainstay of our recent decade of fieldwork at Long Valley. Thanks for helpful manuscript reviews by Steve Lipshie and Allen Glazner, both of them old Long Valley hands. 


\section{References Cited}

Bailey, R.A., 1989, Geologic map of Long Valley caldera, Mono-Inyo Craters volcanic chain, and vicinity, eastern California: U.S. Geological Survey Map I-1933, 11 p., 2 sheets, scale 1:62,500.

Bailey, R.A., 2004, Eruptive history and chemical evolution of the precaldera and postcaldera basalt-dacite sequences, Long Valley, California-Implications for magma sources, current seismic unrest, and future volcanism: U.S. Geological Survey Professional Paper 1692, 75 p.

Bailey, R.A., Dalrymple, G.B., and Lanphere, M.A., 1976, Volcanism, structure, and geochronology of Long Valley caldera, Mono County, California: Journal of Geophysical Research, v. 81, no. 5, p. 725-744.

Bateman, P.C., 1965, Geology and tungsten mineralization of the Bishop District, California: U.S. Geological Survey Professional Paper 470, 208 p.

Bateman, P.C., 1992, Plutonism in the central part of the Sierra Nevada batholith, California: U.S. Geological Survey Professional Paper 1483, 186 p.

Battaglia, M., Roberts, C., and Segall, P., 1999, Magma intrusion beneath Long Valley Caldera confirmed by temporal changes in gravity: Science, v. 285, p. 2119-2112.

Battaglia, M., Segall, P., Murray, J., Cervelli, P., and Langbein, J., 2003a, The mechanics of unrest at Long Valley caldera, California-1., Modeling the geometry of the source using GPS, leveling and two-color EDM data: Journal of Volcanology and Geothermal Research, v. 127, p. 195-217.

Battaglia, M., Segall, P., and Roberts, C., 2003b, The mechanics of unrest at Long Valley caldera, California-2.

Constraining the nature of the source using geodetic and micro-gravity data: Journal of Volcanology and Geothermal Research, v. 127, p. 219-245.

Battaglia, M., and Vasco, D.W., 2006, The search for magma reservoirs in Long Valley Caldera-Single versus distributed sources, in Troise, C., DeNatale, G., and Kilburn, C.R.J., eds., Mechanisms of activity and unrest at large calderas: Geological Society of London Special Publication 269, p. 173-180.

Benioff, H., and Gutenberg, B., 1939, The Mammoth "Earthquake Fault" and related features in Mono County, California: Seismological Society of America Bulletin, v. 29, p. 333-340.
Berger, W.H., Bickert, T., Schmidt, H., and Wefer, G., 1993, Quaternary oxygen isotope record of pelagic foraminifersSite 806, Ontong Java Plateau, in Berger, W.H., Kroenke, L.W., Mayer, L.A., eds., Proceedings of the Ocean Drilling Program, scientific results: College Station, Texas, Ocean Drilling Program, v. 130, p. 381-395.

Bergfeld, D., Evans, W.C., Howle, J.F., and Farrar, C.D., 2006, Carbon dioxide emissions from vegetation-kill zones around the resurgent dome of Long Valley caldera, eastern California, USA: Journal of Volcanology and Geothermal Research, v. 152, p. 140-156.

Berra, Y., 2001, When you come to a fork in the road, take it: New York, Hyperion, 175 p.

Blackwelder, E., 1931, Pleistocene glaciation in the Sierra Nevada and Basin Ranges: Geological Society of America Bulletin, v. 42, p. 865-922.

Carle, S.F., 1988, Three-dimensional gravity modeling of the geologic structure of Long Valley caldera: Journal of Geophysical Research, v. 93, no. B11, p. 13,237-13,250.

Chamberlain, K.J., Wilson, C.J.N., Wallace, P.J., and Millet, M.-A., 2015, Micro-analytical perspectives on the Bishop Tuff and its magma chamber: Journal of Petrology, v. 56, p. 605-640.

Cook, A.C., Hainsworth, L.J., Sorey, M.L., and Evans, W.C., 2001, Radiocarbon studies of plant leaves and tree rings from Mammoth Mountain, CA-A long-term record of magmatic $\mathrm{CO}_{2}$ release: Chemical Geology, v. 177, p. $117-131$.

Curry, R.R., 1968, Quaternary glacial history of the Mammoth Lakes region, Sierra Nevada, California-Section II of Quaternary climatic and glacial history of the Sierra Nevada, California: Berkeley, University of California, Ph.D. dissertation, $108 \mathrm{p}$.

Curry, R.R., 1971, Glacial and Pleistocene history of the Mammoth Lakes Sierra - a geologic guidebook: University of Montana Department of Geology, Geological Series Publication No. 11, 49 p.

Davies, G.R., and Halliday, A.N., 1998, Development of the Long Valley rhyolitic magma system-Strontium and neodymium isotope evidence from glasses and individual phenocrysts: Geochimica et Cosmochimica Acta, v. 62, p. 3561-3574.

Dixon, T.H., Miller, M., Farina, F., Wang, H., and Johnson, D., 2000, Present-day motion of the Sierra Nevada block and some tectonic implications for the Basin and Range province, North American Cordillera: Tectonics, v. 19, p. 1-24.

Doell, R.R., Dalrymple, G.B., and Cox, A., 1966, Geomagnetic polarity epochs - Sierra Nevada data, 3: Journal of Geophysical Research, v. 71, p. 531-541. 
Eichelberger, J.C., Lysne, P.C., Miller, C.D., and Younker, L.W., 1985, Research drilling at Inyo domes, California-1984 results: Eos, v. 66, p. 186-187.

Eichelberger, J.C., Vogel, T.A., Younker, L.W., Miller, C.D., Heiken, G.H., and Wohletz, K.H., 1988, Structure and stratigraphy beneath a young phreatic vent- South Inyo Crater, Long Valley Caldera, California: Journal of Geophysical Research, v. 93, p. 13,208-13,220.

Evans, B.W., Hildreth, W., Bachmann, O., and Scaillet, B., 2016, In defense of magnetite-ilmenite thermometry in the Bishop Tuff and its implications for gradients in silicic magma reservoirs: American Mineralogist, v. 101, p. 469-482.

Farrar, C.D., Sorey, M.L., Evans, W.C., Howle, J.F., Kerr, B.D., Kennedy, B.M., King, C.-Y., and Southon, J.R., 1995, Forest-killing diffuse $\mathrm{CO}_{2}$ emission at Mammoth Mountain as a sign of magmatic unrest: Nature, v. 376, p. 675-678.

Farrar, C.D., Sorey, M.L., Roeloffs, E., Galloway, D.L., Howle, J.F., and Jacobson, R., 2003, Inferences on the hydrothermal system beneath the resurgent dome in Long Valley caldera, east-central California, USA, from recent pumping tests and geochemical sampling: Journal of Volcanology and Geothermal Research, v. 127, p. 305-328.

Fialko, Y., Simons, M., and Khazan, Y., 2001, Finite source modelling of magmatic unrest in Socorro, New Mexico, and Long Valley, California: Geophysical Journal International, v. 146, p. 191-200.

Fierstein, J., and Hildreth, W., 1992, The plinian eruptions of 1912 at Novarupta, Katmai National Park, Alaska: Bulletin of Volcanology, v. 54, p. 646-684.

Fiske, R.S., and Tobisch, O.T., 1994, Middle Cretaceous ash-flow tuff and caldera-collapse deposit in the Minarets Caldera, east-central Sierra Nevada, California: Geological Society of America Bulletin, v. 106, p. 582-593.

Fournier, R.B., 1989, Lithology, mineralogy, and paleontology of Quaternary lake deposits in Long Valley caldera, California: U.S. Geological Survey Open-File Report 89-413, 95 p.

Gerlach, T.M., Doukas, M.P., McGee, K.A., and Kessler, R., 1999, Airborne detection of diffuse carbon dioxide emissions at Mammoth Mountain, California: Geophysical Research Letters, v. 26, no. 24, p. 3661-3664.

Greene, D.C., and Stevens, C.H., 2002, Geologic map of Paleozoic rocks in the Mount Morrison Pendant, eastern Sierra Nevada, California: California Division of Mines and Geology Map Sheet 53, scale 1:24,000.

Gresswell, W.K., 1940, Short report on geological formations encountered in driving the Mono Craters tunnel: California Division of Mines and Geology Bulletin, v. 36, p. 199-204.
Halliday, A.N., Fallick, A.E., Hutchinson, J., and Hildreth, W., 1984, A Nd, Sr, and O isotopic investigation into the causes of chemical and isotopic zonation in the Bishop Tuff, California: Earth and Planetary Science Letters, v. 68, p. 379-391.

Heumann, A., 1999, Timescales of processes within silicic magma chambers: Amsterdam, The Netherlands, Vrije Universiteit, Ph.D. dissertation, $200 \mathrm{p}$.

Heumann, A., and Davies, G.R., 1997, Isotopic and chemical evolution of the post-caldera rhyolitic system at Long Valley, California: Journal of Petrology, v. 38, p. 1661-1678.

Heumann, A., Davies, G.R., and Elliott, T., 2002, Crystallization history of rhyolites at Long Valley, California, inferred from combined U-series and $\mathrm{Rb}-\mathrm{Sr}$ isotope systematics: Geochimica et Cosmochimica Acta, v. 66, no. 10, p. 1821-1837.

Hildreth, E.W., 1977, The magma chamber of the Bishop Tuff-Gradients in temperature, pressure, and composition: Berkeley, University of California, Ph.D. dissertation, 328 p.

Hildreth, W., 1979, The Bishop Tuff-Evidence for the origin of compositional zonation in silicic magma chambers: Geological Society of America Special Paper, v. 180, p. 43-75.

Hildreth, W., 2004, Volcanological perspectives on Long Valley, Mammoth Mountain, and Mono Craters - several contiguous but discrete systems: Journal of Volcanology and Geothermal Research, v. 136, p. 169-198.

Hildreth, W., 2017, Fluid-driven uplift at Long Valley Caldera, California - geologic perspectives: Journal of Volcanology and Geothermal Research, v. 341, p. 269-286.

Hildreth, W., and Fierstein, J., 2012, The Novarupta-Katmai eruption of 1912 - Largest eruption of the Twentieth Century-Centennial Perspectives: U.S. Geological Survey Professional Paper 1791, $260 \mathrm{p}$.

Hildreth, W., and Fierstein, J., 2016a, Eruptive history of Mammoth Mountain and its mafic periphery: U.S. Geological Survey Professional Paper 1812, 128 p., 2 sheets, scale $1: 24,000$.

Hildreth, W., and Fierstein, J., 2016b, Long Valley Caldera lake and reincision of Owens River Gorge: U.S. Geological Survey Scientific Investigations Report 2016-5120, 63 p.

Hildreth, W., Fierstein, J., and Calvert, A., 2017, Early postcaldera rhyolite and structural resurgence at Long Valley caldera, California: Journal of Volcanology and Geothermal Research, v. 335, p. 1-34. 
Hildreth, W., Fierstein, J., Champion, D, and Calvert, A., 2014, Mammoth Mountain and its mafic periphery-A late Quaternary volcanic field in eastern California: Geosphere, v. 10 , no. 6 , p. $1315-1365$.

Hildreth, W., and Mahood, G.A., 1986, Ring-fracture eruption of the Bishop Tuff: Geological Society of America Bulletin, v. 97, p. 396-403.

Hildreth, W., and Wilson, C.J.N., 2007, Compositional zoning of the Bishop Tuff: Journal of Petrology, v. 48, p. 951-999.

Hill, D.P., 1976, Structure of Long Valley caldera, California, from a seismic refraction experiment: Journal of Geophysical Research, v. 81, p. 745-753.

Hill, D.P., 1992, Temperatures at the base of the seismogenic crust beneath Long Valley Caldera, California, and the Phlegrean Fields Caldera, Italy, p. 432-461 in Gasparini, P., Scarpa, R., and Aki, K., eds., Volcanic seismology: IAVCEI Proceedings in Volcanology, v. 3, Berlin, Springer Verlag.

Hill, D.P., 2006, Unrest in Long Valley Caldera, California, 1978-2004, in Troise, C., De Natale, G., and Kilburn, C.R.J., eds., Mechanisms of activity and unrest at large calderas: Geological Society of London Special Publication 269, p. 1-24.

Hill, D.P., Dzurisin, D., Ellsworth, W.L., Endo, E.T., Galloway, D.L., Gerlach, T.M., Johnston, M.J.S., Langbein, J., McGee, K.A., Miller, C.D., Oppenheimer, D., and Sorey, M.L., 2002: Response plan for volcano hazards in the Long Valley caldera and Mono Craters region, California. U.S. Geological Survey Bulletin 2185, 57 p.

Hill, D.P., Kissling, E., Luetgert, J.H., and Kradolfer, U., 1985, Constraints on the upper crustal structure of the Long Valley-Mono Craters volcanic complex, eastern California, from seismic refraction measurements: Journal of Geophysical Research, v. 90, p. 11135-11150.

Hill, D.P., and Montgomery-Brown, E., 2015, Long Valley caldera and the UCERF depiction of Sierra Nevada range-front faults: Bulletin of the Seismological Society of America, v. 105 , no. 6, p. 3189-3195.

Huber, N.K., and Rinehart, C.D., 1965, Geologic map of the Devils Postpile quadrangle, Sierra Nevada, California: U.S. Geological Survey Map GQ-437, scale 1:62,500.

Hurwitz, S., Christiansen, L.B., and Hsieh, P.A., 2007, Hydrothermal fluid flow and deformation in large calderas-Inferences from numerical simulations: Journal of Geophysical Research, v. 112, B02206, doi:10.1029/2006JB004689.

Hurwitz, S., Farrar, C.D., and Williams, C.F., 2010, The thermal regime in the resurgent dome of Long Valley caldera, California-Inferences from precision temperature logs in deep wells: Journal of Volcanology and Geothermal Research, v. 198, p. 233-240.
Izett, G.A., Obradovich, J.D., and Mehnert, H.H., 1988, The Bishop ash bed (middle Pleistocene) and some older (Pliocene and Pleistocene) chemically and mineralogically similar ash beds in California, Nevada, and Utah: U.S. Geological Survey Bulletin 1675, 37 p.

Jacques, H.L., 1940, Mono Craters tunnel construction problems: Journal of the American Water Works Association, v. 32 , no. 1, p. $43-56$.

Kelleher, P.C., and Cameron, K.L., 1990, The geochemistry of the Mono Craters-Mono Lake Islands volcanic complex, eastern California: Journal of Geophysical Research, v. 95, p. 17643-17659.

Kesseli, J.E., 1941, Studies in the Pleistocene glaciation of the Sierra Nevada, California: University of California Publications in Geography, v. 6, no. 8, p. 315-362.

Langbein, J., 1989, Deformation of the Long Valley Caldera, Eastern California from mid-1983 to mid-1988-Measurements using a two-color geodimeter: Journal of Geophysical Research, v. 94, B4, p. 3833-3849.

Langbein, J.O., 2003, Deformation of the Long Valley caldera, California-Inferences from measurements from 1998 to 2001: Journal of Volcanology and Geothermal Research, v. 127 , p. $247-267$.

Langbein, J., Linker, M., and Tupper, D., 1987, Analysis of two-color geodimeter measurements of deformation within the Long Valley caldera—June 1983 to October 1985: Journal of Geophysical Research, v. 92, B9, p. 9423-9442.

Langbein, J., Hill, D.P., Parker, T.N., and Wilkinson, S.K., 1993, An episode of reinflation of the Long Valley Caldera, eastern California - 1989-1991: Journal of Geophysical Research, v. 98, B9, p. 15851-15870.

Langbein, J., Dzurisin, D., Marshall, G., Stein, R., and Rundle, J., 1995, Shallow and peripheral volcanic sources of inflation revealed by modelling two-color geodimeter and leveling data from Long Valley caldera, California, 1988-1992: Journal of Geophysical Research, v. 100, B7, p. 12487-12495.

LeBas, M.J., Lemaitre, R.W., Streckeisen, A., And Zanettin, B., 1986, A chemical classification of volcanic rocks based on the total alkali-silica diagram: Journal of Petrology, v. 27 , p. $745-750$.

Lewicki, J.L., Hilley, G.E., Shelly, D.R., King, J.C., McGeehin, J.P., Mangan, M., and Evans, W.C., 2014, Crustal migration of $\mathrm{CO}_{2}$-rich magmatic fluids recorded by tree-ring radiocarbon and seismicity at Mammoth Mountain, CA, USA: Earth and Planetary Science Letters, v. 390, p. 52-58.

Liddicoat, J.C., 1993, Matuyama/Brunhes polarity transition near Bishop, California: Geophysical Journal International, v. 112, p. 497-506. 
Liddicoat, J.C., Coe, R.S., and Glen, J.M., 1998, Record of the younger part of the Pringle Falls excursion at Long Valley, California: Geophysical Journal International, v. 135, p. 663-670.

Lin, G., 2015, Seismic velocity structure and earthquake relocation for the magmatic system beneath Long Valley Caldera, eastern California: Journal of Volcanology and Geothermal Research, v. 296, p. 19-30.

Lipman, P.W., 1997, Subsidence of ash-flow calderas-Relation to caldera size and magma chamber geometry: Bulletin of Volcanology, v. 59, p. 198-218.

Lisiecki, L.E., and Raymo, M.E., 2005, A Pliocene-Pleistocene stack of 57 globally distributed $\delta^{18} \mathrm{O}$ records: Paleoceanography, v. 20, PA 1003, doi:10.1029/2004PA001071.

Lucic, G., Stix, J., and Wing, B., 2015, Structural controls on the emission of magmatic carbon dioxide gas, Long Valley caldera, USA: Journal of Geophysical Research, Solid Earth, v. 120, p. 2262-2278, doi:10.1002/2014JB011760.

Mahood, G.A., Ring, J.H., Manganelli, S., and McWilliams, M.O., 2010, $\mathrm{New}{ }^{40} \mathrm{Ar} /{ }^{39} \mathrm{Ar}$ ages reveal contemporaneous mafic and silicic eruptions during the past 160,000 years at Mammoth Mountain and Long Valley caldera, California: Geological Society of America Bulletin, v. 122, p. 396-407.

Mankinen, E.A., Grommé, C.S., Dalrymple, G.B., Lanphere, M.A., and Bailey, R.A., 1986, Paleomagnetism and K-Ar ages of volcanic rocks from Long Valley, California: Journal of Geophysical Research, v. 91, no. B1, p. 633-652.

Manley, C.R., Glazner, A.F., and Farmer, G.L., 2000, Timing of volcanism in the Sierra Nevada of California-Evidence for Pliocene delamination of the batholithic root?: Geology, v. 28 , no. 9 , p. $811-814$.

Mastin, L.G., 1991, The roles of magma and groundwater in the phreatic eruptions at Inyo Craters - Long Valley Caldera, California: Bulletin of Volcanology, v. 53. p. 579-596.

McConnell, V.S., Shearer, C.K., Eichelberger, J.C., Keskinen, M.J., Layer, P.W., and Papike, J.J., 1995, Rhyolite intrusions in the intracaldera Bishop Tuff, Long Valley caldera, California: Journal of Volcanology and Geothermal Research, v. 67, p. 41-60.

Metz, J.M., and Bailey, R.A., 1993, Geologic map of Glass Mountain, Mono County, California: U.S. Geological Survey Map I-1995, scale 1:24,000.

Metz, J.M., and Mahood, G.A., 1985, Precursors to the Bishop Tuff eruption - Glass Mountain, Long Valley, California: Journal of Geophysical Research, v. 90, p. 11121-11126.
Metz, J.M., and Mahood, G.A., 1991, Development of the Long Valley, California, magma chamber recorded in precaldera rhyolite lavas of Glass Mountain: Contributions to Mineralogy and Petrology, v. 106, p. 379-397.

Millar, C.I., King, J.C., Westfall, R.D., Alden, H.A., and Delany, D.L., 2006, Late Holocene forest dynamics, volcanism, and climate change at White Wing Mountain and San Joaquin Ridge, Mono County, Sierra Nevada, CA, USA: Quaternary Research, v. 66, p. 273-287.

Miller, C.D., 1985, Holocene eruptions at the Inyo volcanic chain, California-Implications for possible eruptions in the Long Valley caldera: Geology, v. 13, p. 14-17.

Montgomery-Brown, E.K., Wicks, C.W., Cervelli, P.F., Langbein, J.O., Svarc, J.L., Shelly, D.R., Hill, D.P., and Lisowski, M., 2015, Renewed inflation of Long Valley caldera, California (2011 to 2014): Geophysical Research Letters, v. 42, doi:10.1002/2015GL064338.

Moore, J.G., and Dodge, F.C.W., 1980, Late Cenozoic volcanic rocks of the southern Sierra Nevada, California, I., Geology and petrology: Geological Society of America Bulletin, v. 91, no. 9 part II, p. 1995-2038.

Muttoni, G., Carcano, C., Garzanti, E., Ghielmi, M., Piccin, A., Pini, R., Rogledi, S., and Sciunnach, D., 2003, Onset of major Pleistocene glaciations in the Alps: Geology, v. 31, no.11, p. 989-992.

Nagorsen-Rinke, S., Lee, J., and Calvert, A., 2013, Pliocene sinistral slip across the Adobe Hills, eastern Californiawestern Nevada - Kinematics of fault slip transfer across the Mina Deflection: Geosphere, v. 9, no. 1, p. 37-53.

Nawotniak, S.E.K., and Bursik, M., 2010, Subplinian fall deposits of Inyo Craters, California: Journal of Volcanology and Geothermal Research, v. 198, p. 433-446.

Newman, A.V., Dixon, T.H., and Gourmelen, N., 2006, A fourdimensional viscoelastic deformation model for Long Valley Caldera, California, between 1995 and 2000: Journal of Volcanology and Geothermal Research, v. 150, p. 244-269.

Oldow, J.S., Geissman, J.W., and Stockli, D.F., 2008, Evolution and strain reorganization within late Neogene structural stepovers linking the central Walker Lane and northern Eastern California Shear Zone, western Great Basin: International Geology Review, v. 50, p. 270-290.

Peck, D.L., and Minakami, T., 1968, The formation of columnar joints in the upper part of Kilauean lava lakes, Hawaii: Geological Society of America Bulletin, v. 79, p. 1151-1166.

Phillips, F.M., and Majkowski, L., 2011, The role of low-angle normal faulting in active tectonics of the northern Owens Valley, California: Lithosphere, v. 3, no. 1, p. 22-36. 
Pinter, N., Keller, E.A., and West, R.B., 1994, Relative dating of terraces of the Owens River, northern Owens Valley, California, and correlation with moraines of the Sierra Nevada: Quaternary Research, v. 42, p. 266-276.

Pitt, A.M., Hill, D.P., Walter, S.W., and Johnson, M.J.S., 2002, Midcrustal, long-period earthquakes beneath northern California volcanic areas: Seismological Research Letters, v. 73, no. 2, p. 144-152.

Prejean, S., Ellsworth, W., Zoback, M., and Waldhauser, F., 2002, Fault structure and kinematics of the Long Valley caldera region, California, revealed by high-accuracy earthquake hypocenters and focal mechanism stress inversions: Journal of Geophysical Research, v. 107, no. B12, 2355, doi:10.1029/2001JB001168.

Reid, M.R., Coath, C.D., Harrison, T.M., and McKeegan, K.D., 1997, Prolonged residence times for the youngest rhyolites associated with Long Valley caldera; ${ }^{230} \mathrm{Th}-{ }^{238} \mathrm{U}$ ion microprobe dating of young zircons: Earth and Planetary Sciences Letters, v. 150, p. 27-39.

Rinehart, C.D., and Ross, D.C., 1957, Geology of the Casa Diablo Mountain quadrangle, California: U.S. Geological Survey Map GQ-99, scale 1:62,500.

Rinehart, C.D., and Ross, D.C., 1964, Geology and mineral deposits of the Mount Morrison quadrangle, Sierra Nevada, California: U.S. Geological Survey Professional Paper 385, 106 p., 7 plates, scale 1:62,500.

Ryan, M.P., and Sammis, C.G., 1978, Cyclic fracture mechanisms in cooling basalt: Geological Society of America Bulletin, v. 89, p. 1295-1308.

Sampson, D.E., and Cameron, K.L., 1987, The geochemistry of the Inyo volcanic chain-Multiple magma systems in the Long Valley region, eastern California: Journal of Geophysical Research, v. 92, no. B10, p. 10403-10421.

Sarna-Wojcicki, A.M., Reheis, M.C., Pringle, M.S., Fleck, R.J., Burbank, D., Meyer, C.E., Slate, J.L., Wan, E., Budahn, J.R., Troxel, B., and Walker, J.P., 2005, Tephra layers of Blind Spring Valey and related upper Pliocene and Pleistocene tephra layers, California, Nevada, and UtahIsotopic ages, correlation, and magnetostratigraphy: U.S. Geological Survey Professional Paper 1710, 63 p.

Savage, J.C., and Clark, M.M., 1982, Magmatic resurgence in Long Valley caldera, California-Possible cause of the 1980 Mammoth Lakes earthquakes: Science, v. 217, p. 531-533.

Savage, J.C., and Lisowski, M., 1984, Deformation in the White Mountain Seismic Gap, California-Nevada, 1972-1982: Journal of Geophysical Research, v. 89, B9, p. 7671-7687.
Savage, J.C., Cockerham, R.S., Estrem, J.E., and Moore, L.R., 1987, Deformation near the Long Valley Caldera, eastern California, 1982-1986: Journal of Geophysical Research, v. 92, B3, p. 2721-2746.

Seccia, D., Chiarabba, C., DeGori, P., Bianchi, I., and Hill, D.P., 2011, Evidence for the contemporary magmatic system beneath Long Valley Caldera from local earthquake tomography and receiver function analysis: Journal of Geophysical Research, v. 116, B12314, doi:10.1029/2011JB008471.

Shelly, D.R., Ellsworth, W.L., and Hill, D.P., 2016, Fluidfaulting evolution in high definition-Connecting fault structure and frequency-magnitude variations during the 2014 Long Valley Caldera, California, earthquake swarm: Journal of Geophysical Research, Solid Earth, v. 121, doi:10.1002/2015JB012719.

Shelly, D.R., and Hill, D.P., 2011, Migrating swarms of brittlefailure earthquakes in the lower crust beneath Mammoth Mountain, California: Geophysical Research Letters, v. 38, L20307, doi:10.1029/2011GL049336.

Shelly, D.R., Taira, T., Prejean, S.G., Hill, D.P., and Dreger, D.S., 2015, Fluid-faulting interactions-Fracture-mesh and fault-valve behavior in the February 2014 Mammoth Mountain, California, earthquake swarm: Geophysical Research Letters, v. 42, doi:10.1002/ 2015GL064325.

Sheridan, M.F., 1970, Fumarolic mounds and ridges of the Bishop Tuff, California: Geological Society of America Bulletin, v. 81, p. 851-868.

Simon, J.I., Weis, D., DePaolo, D.J., Renne, P.R., Mundil, R., and Schmitt, A.K., 2014, Assimilation of preexisting Pleistocene intrusions at Long Valley by periodic magma recharge accelerates rhyolite generation - rethinking the remelting model: Contributions to Mineralogy and Petrology, v. 167:955, 35 p.

Smith, R.L., and Bailey, R.A., 1968, Resurgent cauldrons: Geological Society of America Memoir 116, p. 613-662.

Snow, J.K., and Wernicke, B.P., 2000, Cenozoic tectonisn in the central Basin and Range-Magnitude, rate, and distribution of upper crustal strain: American Journal of Science, v. 300, p. 659-719.

Sorey, M.L., Evans, W.C., Kennedy, B.M., Farrar, C.D., Hainsworth, L.J., and Hausback, B., 1998, Carbon dioxide and helium emissions from a reservoir of magmatic gas beneath Mammoth Mountain, California: Journal of Geophysical Research, v. 103, no. B7, p. 15303-15323. 
Sorey, M.L., Kennedy, B.M., Evans, W.C., Farrar, C.D., and Suemnicht, G.A., 1993, Helium isotope and gas discharge variations associated with crustal unrest in Long Valley Caldera, California, 1989-1992: Journal of Geophysical Research, v. 98, B9, p. 15871-15889.

Sorey, M.L., Suemnicht, G.A., Sturchio, N.C., and Nordquist, G.A., 1991, New evidence on the hydrothermal system in Long Valley caldera, California, from wells, fluid sampling, electrical geophysics, and age determinations of hot-spring deposits: Journal of Volcanology and Geothermal Research, v. 48 , p. $229-263$.

Stevens, C.H., Stone, P., and Blakely, R.J., 2013, Structural evolution of the East Sierra Valley System (Owens Valley and vicinity), California-A geologic and geophysical synthesis: Geosciences, v. 3, p. 176-215.

Stockli, D.F., Dumitru, T.A., McWilliams, M.O., and Farley, K.A., 2003, Cenozoic tectonic evolution of the White Mountains, California and Nevada: Geological Society of America Bulletin, v. 115, p. 788-816.

Suemnicht, G.A., 1987, Results of deep drilling in the western moat of Long Valley, California: Eos, v. 68, no. 40, p. 785, 798.

Suemnicht, G.A., Kennedy, B.M., and Evans, W.C., 2015, Helium isotope systematics of Long Valley Caldera, California: Proceedings, World Geothermal Congress 2015, Melbourne, Australia, p. 1-6.

Suemnicht, G.A., Sorey, M.L., Moore, J.N., and Sullivan, R., 2006, The shallow hydrothermal system of Long Valley caldera, California: Geothermal Resources Council Transactions, v. 30, p. 465-469.

Suemnicht, G.A., and Varga, R.J., 1988, Basement structure and implications for hydrothermal circulation patterns in the western moat of Long Valley caldera, California: Journal of Geophysical Research, v. 93, no. B11, p. 13191-13207.

Thatcher, W., and Massonnet, D., 1997, Crustal deformation at Long Valley Caldera, eastern California, 1992-1996, inferred from satellite radar interferometry: Geophysical Research Letters, v. 24, no. 20, p. 2519-2522.

Tiampo, K.F., Rundle, J.B., Fernandez, J., and Langbein, J.O., 2000, Spherical and ellipsoidal volcanic sources at Long Valley caldera, California, using a genetic algorithm inversion technique: Journal of Volcanology and Geothermal Research, v. 102, p. 189-206.

Tizzani, P., Battaglia, M., Zeni, G., Atzori, S., Berardino, P., and Lanari, R., 2009, Uplift and magma intrusion at Long Valley caldera from InSAR and gravity measurements: Geology, v. 37, p. 63-66.
Varga, R.J., Bailey, R.A., and Suemnicht, G.A., 1990, Evidence for 600-year-old basalt and magma mixing at Inyo Craters volcanic chain, Long Valley caldera, California: Journal of Geophysical Research, v. 95, no. B13, p. 2144121450 .

Vogel, T.A., Eichelberger, J.C., Younker, L.W., Schuraytz, B.C., Horkowitz, J.P., Stockman, H.W., and Westrich, H.R., 1989, Petrology and emplacement dynamics of intrusive and extrusive rhyolites of Obsidian Dome, Inyo Craters Volcanic Chain, eastern California: Journal of Geophysical Research, v. 94, p. 17,937-17,956.

Vogel, T.A., Woodburne, T.B., Eichelberger, J.C., and Layer, P.W., 1994, Chemical evolution and periodic eruption of mafic lava flows in the West Moat of Long Valley Caldera, California: Journal of Geophysical Research, v. 99, no. B10, p. 19829-19842.

Wallace, P.J., Anderson, A.T., Jr., and Davis, A.M., 1999, Gradients in $\mathrm{H}_{2} \mathrm{O}, \mathrm{CO}_{2}$, and exsolved gas in a large-volume silicic magma system - Interpreting the record preserved in melt inclusions from the Bishop Tuff: Journal of Geophysical Research, v. 104, p. 20097-20122.

Warner Holt, E., and Taylor, H.P., Jr., $1998,{ }^{18} \mathrm{O} /{ }^{16} \mathrm{O}$ mapping and hydrogeology of a short-lived ( $\sim 10$ years) fumarolic $\left(>500^{\circ} \mathrm{C}\right)$ meteoric-hydrothermal event in the upper part of the 0.76 Ma Bishop Tuff outflow sheet, California: Journal of Volcanology and Geothermal Research, v. 83, p. $115-139$.

Werner, C., Bergfeld, D., Farrar, C.D., Doukas, M.P., Kelly, P.J., and Kern, C., 2014, Decadal-scale variability of diffuse $\mathrm{CO}_{2}$ emissions and seismicity revealed from long-term monitoring (1995-2013) at Mammoth Mountain, California, USA: Journal of Volcanology and Geothermal Research, v. 289, p. 51-63.

Wilson, C.J.N., and Hildreth, W., 1997, The Bishop TuffNew insights from eruptive stratigraphy: Journal of Geology, v. 105, p. 407-439.

Wilson, C.J.N., and Hildreth, W., 1998, Hybrid fall deposits in the Bishop Tuff, California-A novel pyroclastic depositional mechanism: Geology, v. 26, p. 7-10.

Wilson, C.J.N., and Hildreth, W., 2003, Assembling an ignimbrite-Mechanical and thermal building blocks in the Bishop Tuff, California: Journal of Geology, v. 111, p. 653-670.

Wood, S.H., 1977, Distribution, correlation, and radiocarbon dating of late Holocene tephra, Mono and Inyo craters, eastern California: Geological Society of America Bulletin, v. 88, p. $89-95$. 


\section{A Refreshing Overview of the Bishop Tuff}

By Wes Hildreth 


\title{
A Refreshing Overview of the Bishop Tuff
}

\author{
By Wes Hildreth
}

\section{Abstract}

The Bishop Tuff, pyroclastic product of the 767-ka caldera-forming eruption at Long Valley, represents evacuation of $\sim 650 \mathrm{~km}^{3}$ of rhyolite magma from a unitary zoned chamber in 5-6 days. Here I give concise summaries of (1) the original distribution of the eruptive products, (2) the continuity and duration of the eruption, (3) the sequence of concurrent fall and flow deposits, (4) the migration of ring vents and resulting sectorial array of ignimbrite, (5) progressive change of proportions in the eruptive mixture of pumice clasts of contrasting texture, composition, and crystallinity, and (6) continuity of bulk composition, melt composition, and compositions of unzoned phenocryst species - comprehensive zonation that was established prior to late-stage injection of less evolved rhyolite of slightly higher temperature. Zonation in melt composition reflected secular assembly of countless batches of rhyolitic melt that separated from a pluton-scale reservoir of granitic crystal mush. Each batch rose to its appropriate level in the melt-buoyancy gradient, which was largely imposed by gradients in dissolved water and exsolved gas bubbles and which sustained the compositional gradient against convective homogenization. Crystallization of quartz, sanidine, plagioclase, biotite, allanite, ilmenite, magnetite, apatite, and zircon followed establishment of the gradients in melt composition and buoyancy but preceded injection of the higher-temperature late-stage batches of less-evolved rhyolite. Compared to resident rhyolite magma, the late injections were enriched in $\mathrm{Ti}, \mathrm{Ba}, \mathrm{Sr}$, and $\mathrm{CO}_{2}$, and they principally affected deeper levels of the chamber that were tapped relatively late during the caldera-forming eruptive sequence. The late injections introduced pyroxene phenocrysts, induced marginal resorption of quartz and sanidine, and (after decay of the thermal pulse) promoted rim overgrowths on quartz, sanidine, and zircon. Based on gas-saturated $\mathrm{H}_{2} \mathrm{O}-\mathrm{CO}_{2}$ solubility relations, melt inclusions within the late-stage quartz rims yield entrapment pressures as much as 1 kilobar greater than do melt inclusions from early parts of the eruptive sequence, consistent with $2-3 \mathrm{~km}$ of subsidence of the caldera's roof plate. Compositions of melt inclusions inboard of the late-stage overgrown rims on the reheated quartz crystals, however, appear to have been modified and are thus unrepresentative of their entrapment conditions or compositions. Fe-Ti oxide equilibria yield a thermal gradient of 700 to $850{ }^{\circ} \mathrm{C}$ within the magma reservoir evacuated, about two-thirds of which (700 to $\sim 780^{\circ} \mathrm{C}$ ) was present before the late-stage injections.

\section{Introduction}

The Bishop Tuff (fig. 1) is the pyroclastic product of $\sim 650 \mathrm{~km}^{3}$ of rhyolitic magma that erupted explosively during collapse of Long Valley Caldera at $\sim 767 \mathrm{ka}$. Owing to its good preservation, exposure, and accessibility, to extensive stratigraphic and petrologic data, and to fascinating inferences from those data about eruptive and pre-eruptive processes, the Bishop Tuff has attracted global attention as a paradigmatic model of a caldera-forming eruptive unit. Following the early studies by Gilbert (1938), Sheridan (1970), and Hildreth (1977, 1979, 1981), there have been (through 2016) more than 75 published articles concerning aspects of the Bishop Tuff. Most of these are cited in papers by Wilson and Hildreth (1997), Hildreth and Wilson (2007), Chamberlain and others (2014a, b, 2015), and Evans and others (2016).

\section{Well-Established Characteristics of the Bishop Tuff}

Distribution. Half the $\sim 650 \mathrm{~km}^{3}$ magma volume that erupted was trapped within the subsiding caldera; one-third flowed 40-70 km radially as ignimbrite outflow sheets; and about one-sixth was dispersed continentally as plinian and coignimbrite fallout (Hildreth and Wilson, 2007). Ignimbrite outflow blanketed roughly twice the area exposed today; distal ignimbrite, now eroded or buried, initially covered Adobe Valley, Chalfant-Benton Valley, and much of Mono Basin, as well as south into Owens Valley at least as far as Big Pine. Because of glacial erosion in the Sierra Nevada, the volume of Bishop Tuff along the Middle Fork canyon of the San Joaquin River has been underappreciated; ash flows poured over Minaret Summit and Mammoth Crest, ponded in the canyon to welded thicknesses as great as $200 \mathrm{~m}$, and covered at least $70 \mathrm{~km}^{2}$ there.

Fall Deposition Continuity. Deposition of plinian fallout was contemporaneous with emplacement of the sequence of 11 ignimbrite packages (fig. 2) defined by Wilson and Hildreth (1997) on the basis of distinguishable populations of lithic and pumice types. Each temporally and geographically defined package was emplaced as a series of pulses or ash-flow units with similar pumice and lithic suites (but independent of welding zonation). There was no discernible interruption in accumulation of the fallout sequence, which was divided into nine conformable layers (F1-F9). A slight pause in deposition 


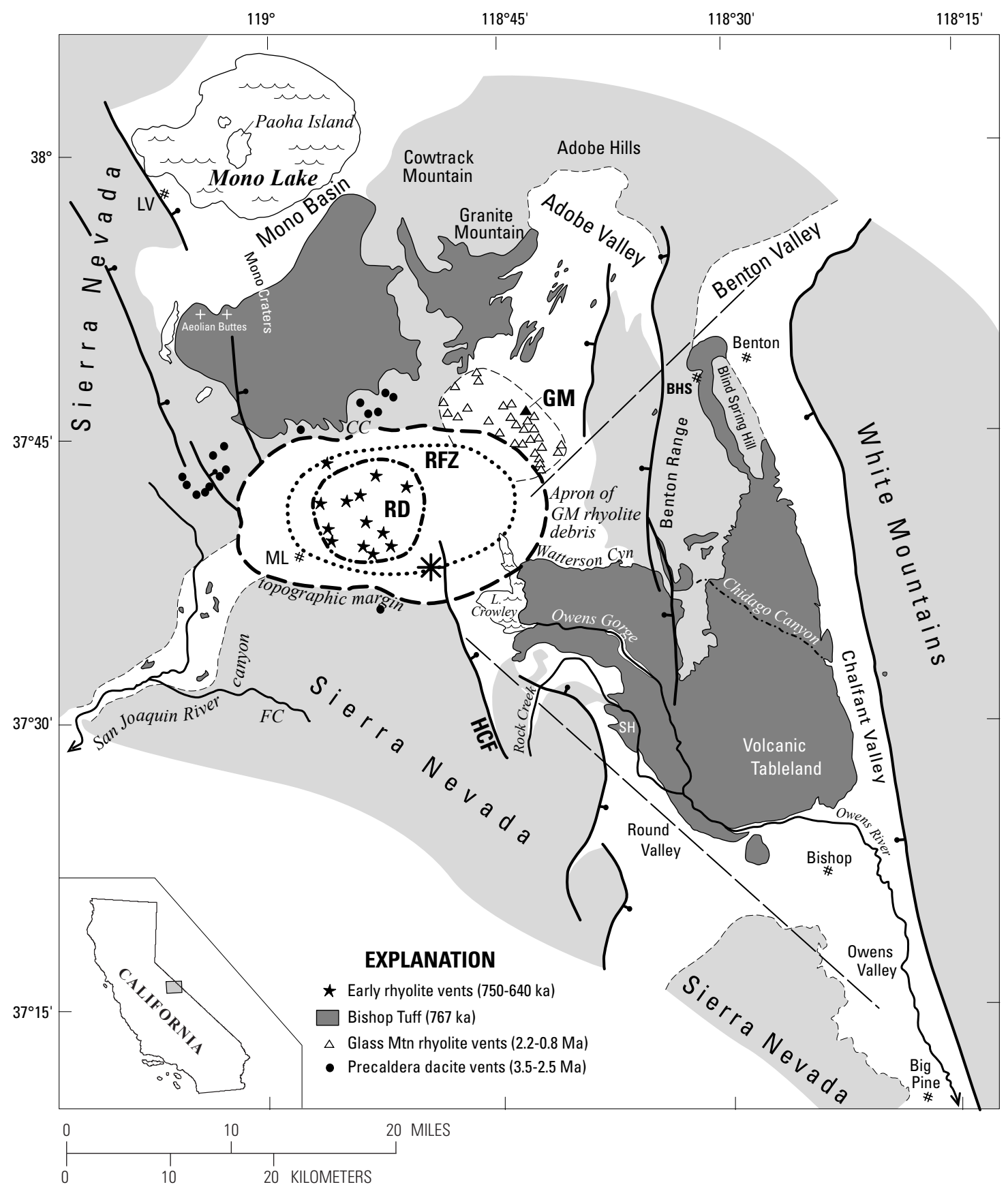

Figure 1. Outline map of Long Valley Caldera and distribution of the Bishop Tuff (dark gray shading), straddling the transition from extended Basin-and-Range Province to Sierra Nevada microplate. Shown for the caldera are its topographic margin (heavy dashed line), ring-fault zone (RFZ; dotted), and limit of structurally uplifted resurgent dome (RD; dash-dot). Exposed vents for precaldera dacites, precaldera Glass Mountain (GM) rhyolites, and postcaldera early rhyolite are identified in legend (Bailey, 1989; Metz and Bailey, 1993). Drilling has shown subsurface Bishop Tuff to extend northwest beneath Paoha Island in Mono Lake, southeast beneath Big Pine, and to be as thick as 1,500 m beneath the caldera floor. Before erosion and burial, Bishop Tuff ignimbrite probably covered all of Mono Basin, Adobe Valley, Benton Valley, Chalfant Valley, Owens Valley at least as far south as Big Pine, and the canyon of the San Joaquin River as far as $50 \mathrm{~km}$ downstream. The dark-shaded areas of present-day outcrops thus represent only about half the original ignimbrite distribution. Plinian pumice-fall deposits are preserved only within the easterly sector confined by the two long-dash lines, though primary plinian ashfall is also found outside this sector as far as Owens Lake (160 km southeast) and Friant Dam (110 km southwest). Large asterisk indicates initial vent site (for most of Ig1 and most plinian fallout) as inferred by Hildreth and Mahood (1986). Place-name abbreviations are: BHS, Benton Hot Springs; CC, Clark Canyon; FC, Fish Creek; HCF, Hilton Creek Fault; LV, town of Lee Vining; ML, town of Mammoth Lakes; SH, Sherwin Hill. 

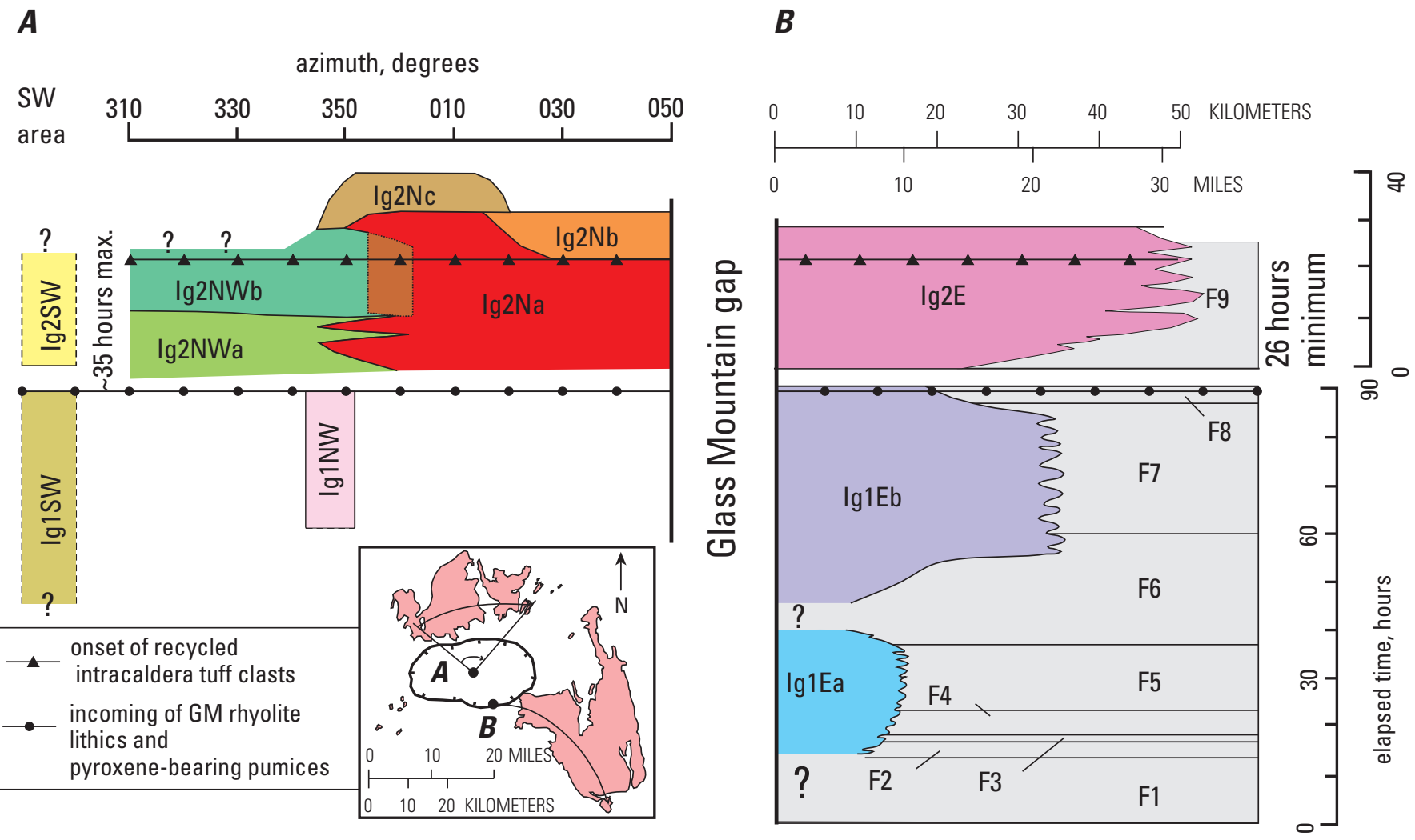

Figure 2. Summary diagram of stratigraphic relations and estimated emplacement durations of Bishop Tuff fall units (F) and ignimbrite packages (Ig), updated from Wilson and Hildreth (1997). "Glass Mountain gap" represents the gap in information northeast of Glass Mountain, where all Bishop deposits have been removed by erosion. Vertical distances are scaled to a composite timescale, which is separated by a short time break between F8 and F9. Left-hand side $(A)$ shows a hypothetical west-to-east section along an arc from $310^{\circ}$ to $050^{\circ}$ (relative to grid north, as projected from an arbitrary origin in the center of Long Valley Caldera; see inset map), with the northern ignimbrite subpackages drawn to represent their projected dispersal sectors (horizontal scale) and relative stratigraphic positions (vertical scale). Right-hand side $(B)$ illustrates a section from proximal to distal areas, roughly along the line of Owens River Gorge; horizontal axis is distance from the initial vent area (Hildreth and Mahood, 1986). Fall deposits are shaded gray and labeled F1 through F9. The two sides of the figure are linked by a pair of inferred time-marker planes: (1) the first appearances of both Glass Mountainderived (GM) rhyolite lithics (eastern ignimbrite and Ig2N) and pyroxene-bearing pumice (both sides); and (2) the first appearance of clasts of recycled intracaldera Bishop Tuff ignimbrite that itself contains rhyolite lithics. On inset map, cluster of small outcrops southwest of caldera are remnants of packages $\lg 1 \mathrm{SW}$ and $\lg 2 \mathrm{SW}$ along glaciated canyon of San Joaquin River.

of plinian pumice is represented by a conformable layer of fines-bearing ashfall, $1-3 \mathrm{~cm}$ thick, that separates F8 and F9 and may have taken an hour or so to accumulate. Layers of fallout, many partially scoured, are widely intercalated within and between packages of ignimbrite. Beyond the distal reach of ash flows, the F1-F9 fallout sequence is uninterruptedly conformable.

Eruption Duration. By comparing accumulation rates of historic plinian eruptions with thickness and lithic-dispersal characteristics similar to those of each of the Bishop Tuff fall units, it was estimated that the F1-F8 sequence took $\sim 90$ hours and F9 an additional 26 hours (Wilson and Hildreth, 1997, tables 3, 4; updated in Hildreth and Wilson, 2007). The earliest ignimbrite package (Ig1Ea) rests on all or part of F2, so emplacement of ash flows is inferred to have begun near the end of the first day of eruption. The final ignimbrite packages were contemporaneous with F9 but could have outlasted it.
Since Ig1 was coeval with F1-F8 and Ig2 with F9, the entire eruptive sequence took no more than 5-6 days.

Initial Ignimbrites. The earliest ignimbrite packages (Ig1Ea, Ig1NW, Ig1SW) contain similar proportions of pumice types (fig. 3) and are exposed along the Middle Fork San Joaquin River, in Owens River Gorge, at Lake Crowley, and to the north at Clark Canyon, where precaldera Owens River had entered what became the site of the caldera (and crossed it on its way to precaldera Owens Gorge; Hildreth and Fierstein, 2016). The earliest ash flows thus spread to the southwest, north, east, and southeast. No Bishop Tuff remnants have been found in the glaciated Sierra Nevada terrain that forms the south wall of the caldera, but ash flows of Ig1SW did cross the similarly elevated southwest wall at Mammoth Crest on the way toward Fish Creek and the Middle Fork.

Progressive Compositional Complexity. Package $\mathrm{Ig} 1 \mathrm{~Eb}$ is more voluminous and more heterogeneous in pumice 
contents (increasing proportions of crystal-rich pumice and the minor variant pumice types) compared to the earliest packages (fig. 3). It spread extensively to the southeast, east, and northeast, where ash flows evidently crossed the southern slope of the precaldera Glass Mountain center.

Migration of Ring-Vent Segments. Ig1 packages and F1-F8 are characterized by (1) a suite of lithic fragments derived from basement rocks in the south-central part of the caldera, by (2) absence of pyroxene-bearing pumice, and by (3) initial scarcity of phenocryst-rich pumice. The transition to Ig2 packages (including late subpackages of Ig1Eb) was marked by increasing fractions of crystal-rich pumice (fig. 3 ), by entry of a small, subsequently increasing, fraction of pyroxene-bearing pumice, and by lithic suites torn from other sectors of the caldera perimeter.

After days of eruption from a limited vent area in the south-central part of the caldera, onset of roof-plate subsidence led to the opening and propagation of new vents (inferred to have been fissure-dominated) along segments of the developing ring-fault zone. Ig1 packages and F1-F8 together make up at least two-thirds of the eruptive volume emplaced outside the caldera. The greatest compositional range and abundance of less evolved material, however, occurs within the Ig2 packages, the last quarter of the eruption, which is distributed to the southwest, northwest, north, east, and southeast. Because the large volume of intracaldera Bishop Tuff is everywhere deeply buried (and altered in drillcores), the proportions of Ig1 and Ig2 material within it are unknown.

Sectorial Sequence of Ignimbrite Outflow Packages. Lithic suites in the Ig2 packages to the southeast, east, northeast, and north are dominated by rhyolitic felsite and obsidian from the precaldera Glass Mountain edifice and the extensive pyroclastic aprons that flank it. The southern apron of rhyolitic pyroclastic material extends from Glass Mountain as far as Lake Crowley at the caldera's southeast margin. Lithics in package Ig2SW along Fish Creek and the Middle Fork San Joaquin River are predominantly granitoids and metamorphic rocks (along with minor basalt), representing the basement on that side of the caldera, as well surface debris entrained by ash flows that descended terrain steep and rugged. Lithics in Ig2NW are mostly mafic lavas and metamorphic rocks typical of caldera-wall rocks in that sector, whereas lithics in $\mathrm{Ig} 2 \mathrm{~N}$ also include large fractions of rhyolite from Glass Mountain (Hildreth and Mahood, 1986), the west ridge of which the Ig2N ash flows traversed. Interfingering of the Ig2NW and Ig2N lithologies shows contemporaneity and continuity of emplacement as well as a progression of vent-segment openings from west to east across the caldera's north margin (fig. 2; figs. 15-18 of Wilson and Hildreth, 1997). The sectorial sequence of ring-vent propagation is well established by the contrasting populations of lithic fragments.

Bulk Compositional Continuum. Compositional arrays (fig. 4), representing analyses of $>400$ individual pumice clasts from all subunits of the Bishop Tuff, are continuous, showing neither compositional gaps nor bimodality (figs. 9-14 of Hildreth and Wilson, 2007, give many more such plots). The main suite of normal white pumice (fig. 3), which accounts for $>90$ percent of the Bishop Tuff, is zoned continuously from $<1$ to $\sim 25$ weight percent crystals and has ranges of 73.4-77.9 percent $\mathrm{SiO}_{2}, 0.40-1.40$ percent $\mathrm{FeO}, 0.42-1.61$ percent $\mathrm{CaO}$, 0.08-0.25 percent $\mathrm{TiO}_{2}, 71-154$ parts per million (ppm) $\mathrm{Zr}$, 7-30 ppm Nb, 75-195 ppm Rb, 9-185 ppm Sr, and 2-614 ppm $\mathrm{Ba}$.

Melt Composition Continuum. Matrix glass in normal white pumice (crystal-poor through crystal-rich; fig. 3) is likewise zoned continuously in major and trace elements across the sequence of emplacement units (Roberge and others, 2013; figs. 8, 9 of Chamberlain and others, 2015). It is thus well established that both bulk and melt zonation developed prior to late-stage injection of batches of slightly less evolved, higher temperature rhyolite (discussed below) that promoted marginal resorption (and subsequent rim overgrowths) on quartz, sanidine, and zircon.

Minor Pumice Types. Subordinate variant pumice (the dark and swirly types of Hildreth and Wilson, 2007) makes up $\sim 5$ percent of the total pumice population (fig. 3). They are rhyolitic but poor in phenocrysts and have matrix glass that is less homogeneous than that of the dominant normal pumice. The minor pumice clasts share the compositional arrays of the main suite but also extend them (fig. 4) to 71 percent $\mathrm{SiO}_{2}, 2.6$ percent $\mathrm{FeO}, 2.6$ percent $\mathrm{CaO}, 0.27$ percent $\mathrm{TiO}_{2}, 260$ ppm Sr, and 850 ppm Ba (fig. 14 of Hildreth and Wilson, 2007).

Ubiquity of All Pumice Varieties. All the different pumice types are present throughout the eruptive sequence (fig. 3). The dark and swirly variants and the crystal-rich ( $>12$ weight percent) normal pumice make up small fractions of the earlyerupted packages, which are dominated by crystal-poor pumice (fig. 3). The abundances of the three increase with eruption progress at the expense of crystal-poor pumice. The increases characterize outflow packages to the east and southeast $(\operatorname{Ig} 1 \mathrm{E}$, Ig2E), as well as those in the Middle Fork San Joaquin River (Ig1SW, Ig2SW) and those to the north and northwest of the caldera (Ig1NW, Ig2NW, Ig2N). The pattern of progressive change in proportions of different pumice types (fig. 3) thus applies to ash flows sequentially deposited in all sectors around the caldera and was evidently intrinsic to magma withdrawal from a common reservoir. The observed mingling of the several pumice types in irregular proportions, most variably during the Ig1/Ig2 transition (fig. 3), suggests localized streamlines of transient withdrawal toward successive ring-vent segments, rather than uniform drawdown of the zoned reservoir.

Zonation Preceded Crystallization. Much of the bulk compositional zonation was established before growth of the phenocrysts. Within each sample, sanidine, plagioclase, biotite, apatite, zircon, and Fe-Ti oxide crystals grew virtually unzoned (in major elements and in backscattered-electron imagery), but each of these mineral species exhibits a clear trend toward less evolved compositions across the eruption sequence, thus reflecting the pre-eruptive gradient in composition of the melt (Hildreth, 1977, 1979; Chamberlain and others, 2015), from which they had crystallized in situ, without subsequent sinking or scrambling. Before the late-stage injection of hotter, 


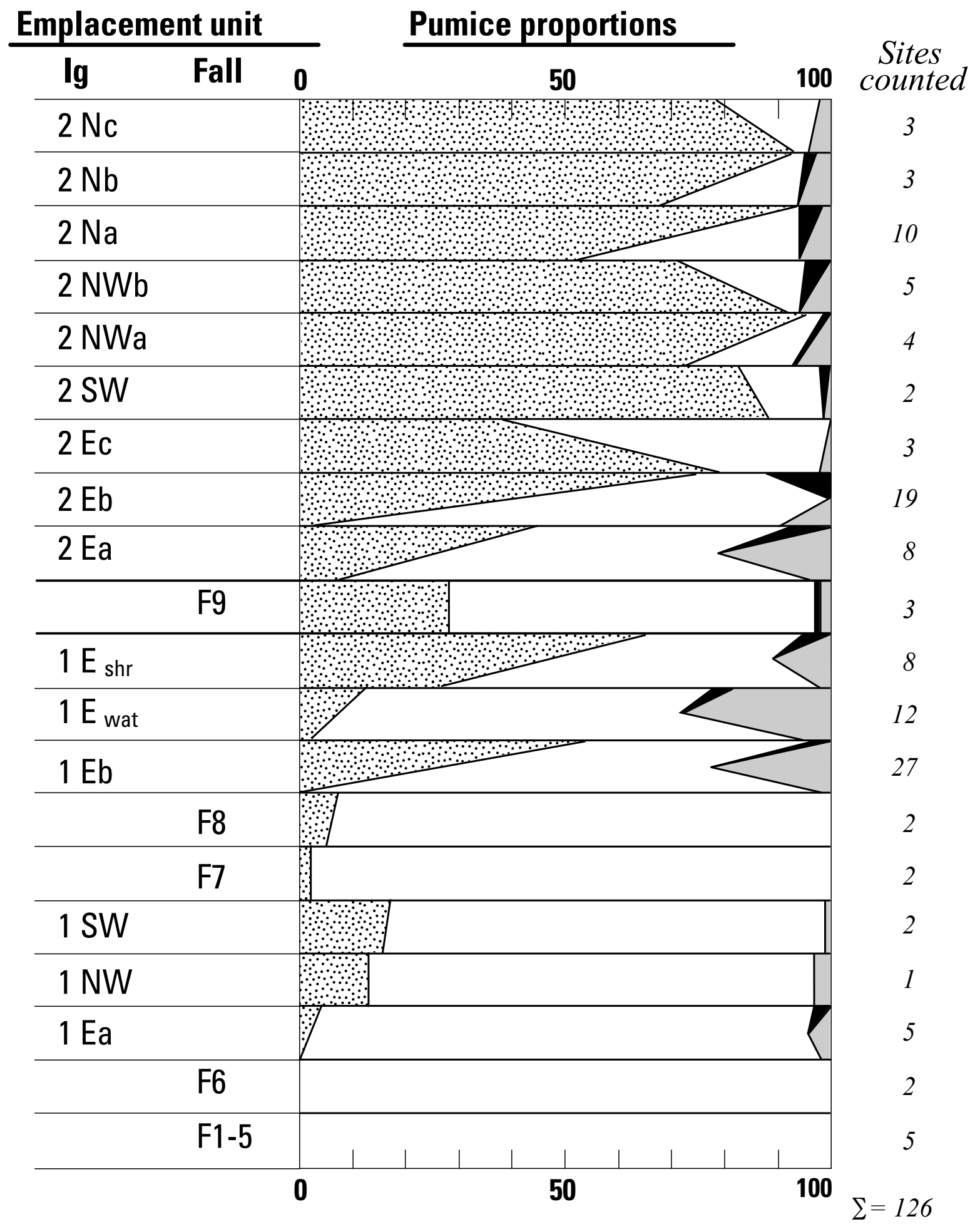

Figure 3. Pumice clast proportions for Bishop Tuff emplacement units of figure 2. Clasts were counted at indicated number of field sites for each unit. Sherwin (shr) and Watterson (wat) subpackages related to Ig1Eb were counted separately (Hildreth and Wilson, 2007). Black, dark-grey pumice; grey, swirly crystal-poor pumice; stipple, normal highsilica pumice with $\geq 12$ percent crystals; unornamented white, normal high-silica pumice with $0.5-12$ percent crystals. Diagonal lines indicate ranges of within-unit variability as counted at different sites. 

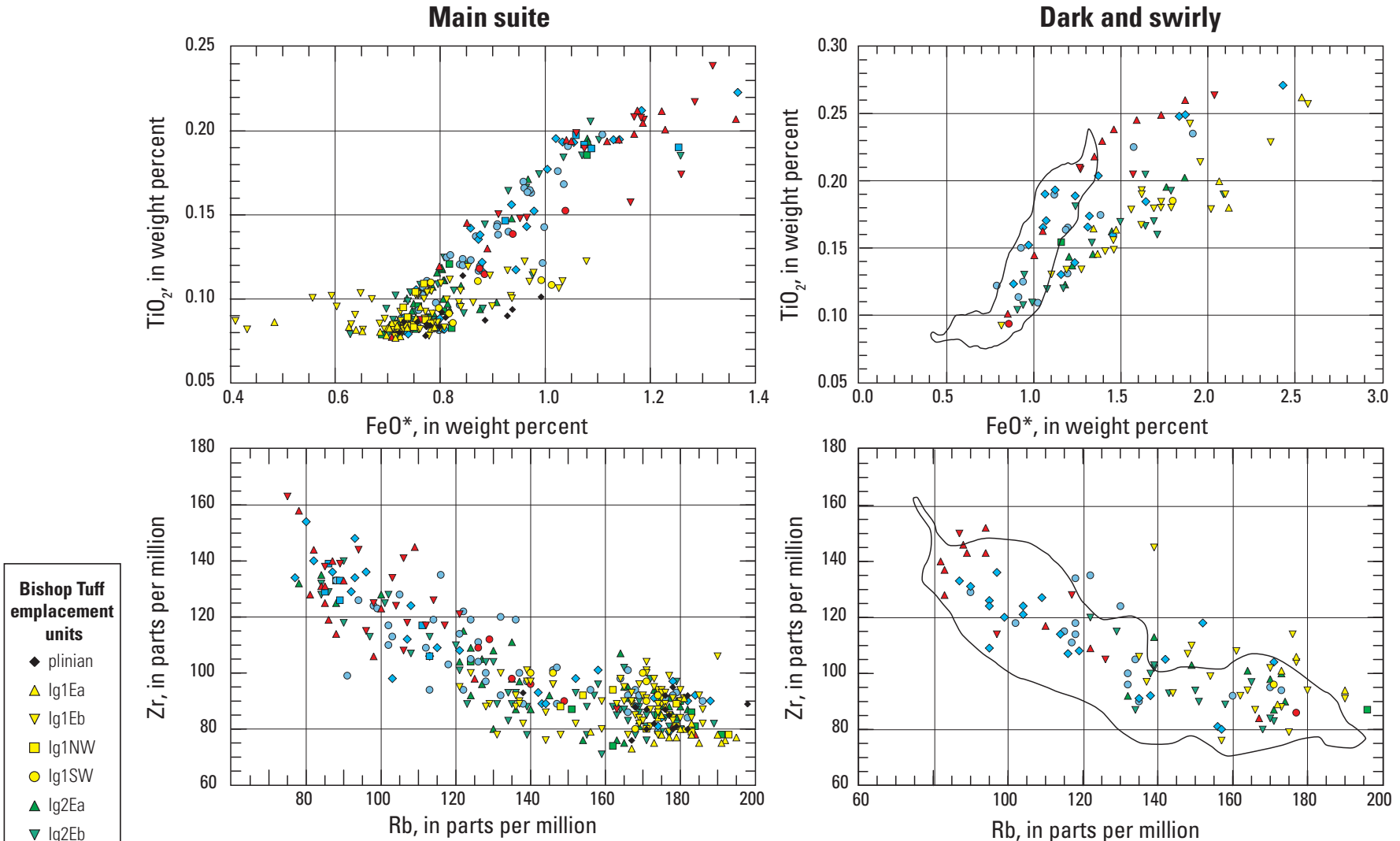

$\nabla \lg 2 \mathrm{~Eb}$

- $\lg 2 \mathrm{Na}$

$\diamond \lg 2 \mathrm{Nb}$

$\square \lg 2 \mathrm{Nc}$

$\nabla$ Ig2NWa

$\Delta \lg 2 \mathrm{NWb}$

- Ig2SW
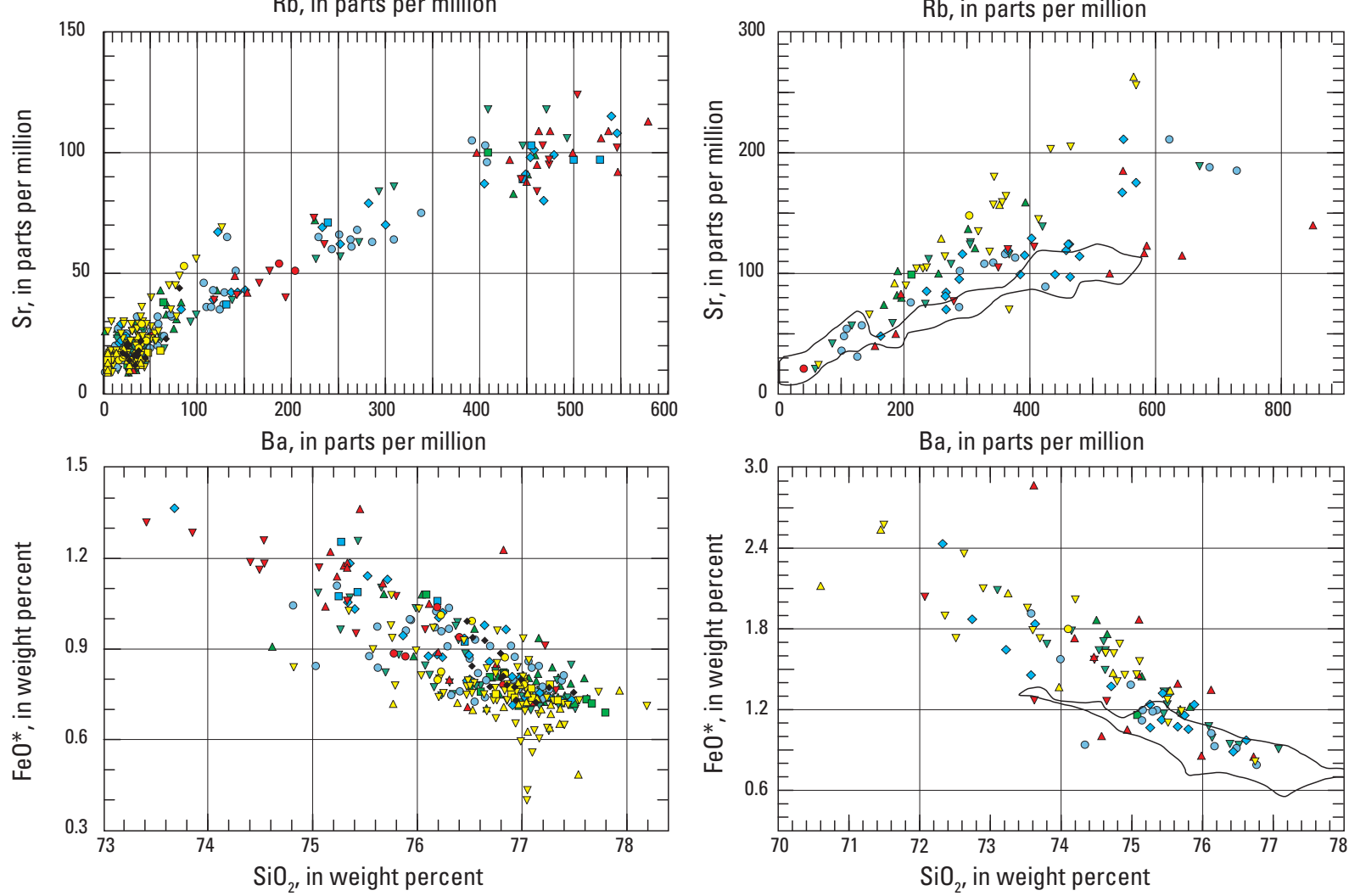

Figure 4. Plots showing compositional variations with eruption progress. Ranges of $\mathrm{SiO}_{2^{\prime}} \mathrm{FeO}^{*}$, and $\mathrm{TiO}_{2}$ and $\mathrm{Zr}$, $\mathrm{Ba}$, $\mathrm{Sr}$, and $\mathrm{Rb}$ for each emplacement unit as shown in figure 2; symbols identified in inset. For clarity, paired panels separate the main suite of normal white pumice from the suite of subordinate dark and swirly pumice (as plotted in figure 3). To facilitate comparison, the field outlines of the former are reproduced in panels of the latter. 
less-evolved magma batches that led to "bright-rim" overgrowths, some sanidines had weak zoning in Ba, but plagioclase, biotite, allanite, and other species showed no systematic differences between cores and rims (Hildreth, 1977, 1979; Chamberlain and others, 2015).

Late-Stage Injection of Batches of "Bright-Rim Magma." Deep parts of the zoned magma volume that subsequently erupted had been injected by batches of slightly hotter rhyolite that was relatively richer in $\mathrm{Ti}, \mathrm{Sr}, \mathrm{Ba}$, and $\mathrm{CO}_{2}$ than the resident magma. Their arrival took place after establishment of the compositional zonation and after still-later growth of the main phenocryst suite. The ensuing mixing promoted marginal resorption of resident phenocrysts and, after modest cooling, overgrowth of "bright rims" (in cathodoluminescence or backscattered-electron imagery) on those crystals - rims richer in Ti on quartz, richer in $\mathrm{Ba}$ and $\mathrm{Sr}$ on sanidine, and poorer in $\mathrm{U}, \mathrm{Th}$, and REE on zircon (Hervig and Dunbar, 1992; Peppard and others, 2001; Wark and others, 2007; Hildreth and Wilson, 2007; Chamberlain and others, 2014a, b, 2015, and references therein). The mixing and reversely zoned rim growths most extensively affected the deeper magma that produced Ig2 and F9, but small amounts of "bright-rim magma" also mixed into the shallower levels that produced Ig1.

Although themselves modified by mixing, the crystalpoor dark and swirly pumice clasts (present throughout Ig1 and Ig2; fig. 3) represent the principal products of the latestage higher-temperature injections. Injection of magma that produced rare crystal-rich dacite pumice clasts present in Ig2 (Hildreth and Wilson, 2007) could also have contributed to the marginal resorption and subsequent "bright-rim" overgrowths on resident crystals.

Pyroxene Phenocrysts. Orthopyroxene and clinopyroxene are euhedral, unresorbed, unzoned (or unsystematically slightly heterogeneous; Chamberlain and others, 2015), and compositionally nearly identical in all samples. Each is sparsely present in F9 and throughout Ig2, where they occur in some (not all) crystal-rich normal pumice and in the dark and swirly pumice clasts. Mineral inclusions (zircon, apatite, Fe-Ti oxides) within both pyroxenes are compositionally similar to coexisting free crystals and to equivalent inclusions in other phases. Both pyroxenes are in oxygen-isotope equilibrium with coexisting quartz, titanomagnetite, and zircon (Bindeman and Valley, 2002). They are in mutual Fe-Mg exchange equilibrium, but not so with the coexisting biotite and Fe-Ti oxides (Evans and Bachmann, 2013). Frost and Lindsley (1992) calculated equilibration at $824 \pm 15^{\circ} \mathrm{C}$ by two-pyroxene thermometry. Similar temperatures were determined for equilibration of $\mathrm{Fe}-\mathrm{Ti}$ oxide pairs in dark pumice (Hildreth and Wilson, 2007). The pyroxenes are clearly not xenocrysts, nor are they un-reequilibrated antecrysts - crystals inherited from a rhyolitic or rhyodacitic precursor. Instead, they were apparently introduced and dispersed unevenly into deep parts of the magma volume that later erupted, by late-stage ascent of recharge batches from otherwise unerupted levels of the reservoir, where they had already crystallized as true phenocrysts.
The presence of pyroxenes is broadly coextensive with crystal-rich normal pumice, with ample amounts of dark and swirly pumice, with abundance of "bright rims" on quartz, sanidine, and zircon, and with the higher-temperature third of the magma volume erupted (Hildreth and Wilson, 2007; see next paragraph below). Chamberlain and others (2015) suggested that some clinopyroxene may have already been a resident phenocryst in deep parts of the chamber when recharge batches introduced the orthopyroxene. Compositional and thermal contrasts $\left(10-30{ }^{\circ} \mathrm{C}\right)$ between the deep, crystal-rich, resident magma and the crystal-poor recharge rhyolites were modest. Slight but unsystematic compositional heterogeneity of some pyroxenes may reflect modification in the actively mixing magma. Concurrently, biotite, ilmenite, and magnetite reequilibrated quickly to their changing host environment, whereas plagioclase was hardly affected, while quartz, sanidine, and zircon underwent marginal resorption, followed by rim overgrowth. The pyroxenes were indigenous to the greater Bishop Tuff reservoir but were initially limited to the deepest parts of it.

Fe-Ti Oxides. Coexisting ilmenite and titanomagnetite, many of them touching pairs, indicate a continuous temperature range of $703-833^{\circ} \mathrm{C}$ (mostly $717-818^{\circ} \mathrm{C}$ ) (fig. 15 of Hildreth and Wilson, 2007), recalculated as $700-850^{\circ} \mathrm{C}$ by the modified calibration of Ghiorso and Evans (2008). The range is corroborated by $\Delta^{18} \mathrm{O}$ (quartz-magnetite) thermometry, which gave a range of $715-815^{\circ} \mathrm{C}$ (Bindeman and Valley, 2002). Two-feldspar thermometry using cores of sanidine inclusions in plagioclase (and vice versa) gave a range of $720-820^{\circ} \mathrm{C}$ (fig. 2 of Chamberlain and others, 2014b) for the zoned Bishop Tuff reservoir prior to any excess thermal pulse caused by injection of the "bright-rim magma." Crystals of both titanomagnetite and ilmenite are euhedral, and the fresh pairs analyzed show no sign of dissolution, corrosion, or oxyexsolution. Titanomagnetite and ilmenite each show wide ranges in minor-element contents $(\mathrm{Al}, \mathrm{Mg}, \mathrm{Mn}, \mathrm{V}, \mathrm{Co}, \mathrm{Cr}, \mathrm{Zn}$, $\mathrm{Sc}, \mathrm{La}, \mathrm{Ta}$ ) that correlate with the temperature gradient they indicate (Hildreth, 1977). Hildreth and Wilson (2007) gave data for 201 pairs that satisfy the $\mathrm{Mn} / \mathrm{Mg}$ partitioning test of Bacon and Hirschmann (1988) and yield a smooth temperature-oxygen fugacity $\left(\mathrm{T}-\mathrm{fO}_{2}\right)$ curve. There are systematic ten-fold decreases in $\mathrm{Mn} / \mathrm{Mg}$ ratio for both titanomagnetite and ilmenite across the $700-850{ }^{\circ} \mathrm{C}$ range, as plotted in figure 6 of Evans and others (2016). Doubts about the validity of the Fe-Ti oxide thermometry, which had arisen principally from the unequilibrated coexisting pyroxenes (introduced by the "bright-rim magma" batches) and in part from the positive $\mathrm{T}-\mathrm{fO}_{2}$ slope, were laid to rest by Evans and others (2016 and references therein). They demonstrated the accuracy of the two-oxide thermometry in recording the Bishop Tuff thermal gradient, which, in part, reflects the rapid reequilbration of the Fe-Ti oxide pairs to the thermal pulse caused by injection of the "bright-rim magma" into deep parts of the reservoir.

Trace Elements in Melt Inclusions. Trace-element data for $>250$ quartz-hosted melt inclusions (MI; Roberge and others, 2013; Wallace and others, 1999) showed that MI 
are compositionally similar to or slightly less evolved than enclosing matrix glass for the first half or more of the eruptive sequence, suggesting that minor in situ crystallization continued after MI entrapment. For crystal-rich magma of the northerly Ig2 packages, the opposite is true, indicating that the enclosing melt became less evolved than the MI, evidently by incremental intermixing of new lower-silica rhyolitic melt batches after quartz entrapment of the highly evolved melt in the MI. For transitional middle parts of the eruptive sequence (Ig2E and some Ig1Eb), these opposing MI/matrix relations coexist, suggesting either spatially nonuniform upward penetration of melt increments in the pre-eruptive chamber, interlayer mixing, or syneruptive scrambling. MI trapped within the "bright rim" quartz overgrowths share with coexisting matrix glass the least evolved rhyolitic compositions of all, relatively enriched in $\mathrm{Ti}, \mathrm{Ba}$, and $\mathrm{Sr}$.

Gradients in $\mathrm{H}_{2} \mathrm{O}$ and $\mathrm{CO}_{2}$ Measured in Melt Inclusions. Measurements by Fourier transform infrared spectroscopy of the same quartz-hosted MI (Roberge and others, 2013; Wallace and others, 1999) yielded wide ranges in $\mathrm{H}_{2} \mathrm{O}$ and $\mathrm{CO}_{2}$ concentration, indicating significant intra-chamber gradients in both. Despite variations within packages, within pumice clasts, and even within quartz grains, and despite suggestions of diffusive loss of a little $\mathrm{H}_{2} \mathrm{O}$ from some MI, most MI from the early emplacement units contain $\sim 5-6$ weight percent $\mathrm{H}_{2} \mathrm{O}$ and $10-200 \mathrm{ppm} \mathrm{CO}_{2}$, whereas most MI from the crystal-rich pumice that dominates the northerly packages have 3.5-5.0 weight percent $\mathrm{H}_{2} \mathrm{O}$ and $150-1,085 \mathrm{ppm}$ $\mathrm{CO}_{2}$ (fig. 10 of Roberge and others, 2013). The MI within the "bright-rim" overgrowths have the highest $\mathrm{CO}_{2}$ concentrations of all, as well as elevated $\mathrm{Ba}, \mathrm{Sr}$, and Ti. Experimentally determined $\mathrm{H}_{2} \mathrm{O}-\mathrm{CO}_{2}$ solubility relations inform calculation of vapor-saturation pressures at times of MI entrapment in the range 150-200 MPa at the top of the pre-eruptive chamber and 200-280 MPa at the level of late MI entrapment in the "bright-rim" overgrowths (fig. 10 of Wallace and others, 1999; fig. 10a of Roberge and others, 2013). Inverse correlation between concentrations of $\mathrm{CO}_{2}$ and incompatible trace elements in MI confirms that the magma was gas-saturated during crystallization, with $\mathrm{CO}_{2}$ and $\mathrm{Cl}$ partitioning into the gas phase (Wallace and others, 1999). They calculated a steep pre-eruptive gradient in exsolved gas bubbles, ranging from $\sim 1$ weight percent at the deepest levels sampled to $\sim 6$ weight percent near the top, which is similar to the mass fraction of $\mathrm{H}_{2} \mathrm{O}$ that was concurrently dissolved in the melt near the top. The gradients in exsolved gas and in dissolved water stabilized the chamber against convective rehomogenization. Decline in activity of water with depth, owing to less dissolved water and more dissolved $\mathrm{CO}_{2}$, explains the equilibrium crystallization of the quartz-sanidine-plagioclase assemblage at $\sim 70{ }^{\circ} \mathrm{C}$ near the roof and at $\sim 800^{\circ} \mathrm{C}$ at depth (Hildreth, 1979; Wallace and others, 1999; Evans and others, 2016).

Wide Range in Crystal Contents. The mass fraction of phenocrysts in individual pumice clasts ranges widely in the Bishop Tuff (Hildreth and Wilson, 2007). Most plinian and Ig1 pumice contains $<10$ weight percent crystals, many with as little as $1-5$ weight percent. Most pumice in Ig2 contain 10-25 weight percent, except that transitional package Ig2E and late subpackages of Ig1Eb contain abundant pumice of all types (fig. 3). Dark and swirly variant pumice clasts are nearly all crystal-poor. For the continuous array of normal white pumice with 1-25 weight percent crystals, quantitative mineral separation documented a rough correlation between phenocryst content and pumice composition (fig. 7 of Hildreth and Wilson, 2007). Together with the gradients in composition of unzoned phenocrysts, this correlation confirms that the chamber (prior to injection of the "bright-rim" magma) was compositionally zoned prior to crystallization, that the $\mathrm{H}_{2} \mathrm{O}$ gradient governed the extent of crystallization, and that crystal accumulation was not a significant compositional control. Deeper, highertemperature domains of the chamber had crystallized more extensively than shallow domains because of the gradients in $\mathrm{H}_{2} \mathrm{O}$ and $\mathrm{CO}_{2}$ just discussed.

\section{Misconceptions and Misinterpretations}

Use and Misuse of "Early" and "Late." Predominance of highly evolved crystal-poor pumice early in the eruptive sequence and of less evolved crystal-rich pumice later in the sequence has lured some investigators into simplifying their analysis into comparison of small data sets that were thought to represent "Early Bishop Tuff" (EBT) and "Late Bishop Tuff" (LBT). Such oversimplification ignores the minority of crystal-rich (and even sparse "bright-rim") material that erupted early, the subordinate but abundant crystal-poor pumice that erupted late, and the abundance of all types of pumice in transitional packages Ig1E and Ig2E (fig. 3). I introduced use of EBT/LBT (or simply E/L) as a device to plot the compositional extremes of the continuous chemical zonation (Hildreth, 1977, 1979), and it was never intended to suggest a bimodality that does not in fact exist (fig. 4). "Early" and "Late" have been variously used by others to signify (1) the relative sequence of heterogeneous emplacement units (figs. 2,3) withdrawn from the chamber, (2) the relative time of entrapment of melt inclusions during crystal growth, (3) processes before versus during and after the late-stage addition of the "bright-rim magma" that led to crystal resorption and overgrowths, (4) absence or presence of pyroxene phenocrysts, or (5), most simplistically of all, crystal-poor versus crystal-rich pumice. There is thus a conceptually critical distinction in use of the temporal terms "Early" and "Late" between the sequence of heterogeneous eruptive packages and the sequence of precaldera processes in the magma chamber. My preference is that "Early" and "Late" be limited to (1); some petrologists may prefer (3); but, whatever the choice, one should specify it clearly.

A few commentators have simplified the Early versus Late discussion to comparison of a handful of samples from an accessible quarry in the plinian fall deposit with those 
from an outcrop or two in Ig2NW, without acknowledging the ranges of composition, texture, and crystal content coexisting at these and all other sites. Such oversimplifications have distorted some stratigraphic and petrologic discussions toward misapprehension of a nonexistent Early/Late compositional bimodality.

Sectorial Distribution of Outflow Sheets from a Unitary Chamber. Relatively large fractions of crystal-rich pumice in most of the northerly ignimbrite packages and of crystal-poor pumice in some southeasterly packages has fed cursory suggestions that a pair of laterally independent magma bodies erupted concurrently. Abundant evidence against such an idea and the evidence supporting a unitary zoned chamber was elaborated on pages 977-979 of Hildreth and Wilson (2007). All types and compositions of pumice occur in all geographic sectors and in all ignimbrite packages (fig. 3), including the dark and swirly variants and pumice containing "bright-rimmed" crystals. Quartz resorption and Ti-rich rim overgrowths in all sectors and packages is hard to reconcile with separate chambers. There is no evidence for separate distribution patterns of plinian fallout that might reflect eruptioninitiating outbreaks from different chambers. Propagation of ring faults along opposite sides of the collapsing caldera produced a single ovoid depression, elongate east-west (not north-south), with a smoothly continuous margin, consistent with subsidence of a unitary roof plate. The precaldera Glass Mountain rhyolitic edifice is outside the structural caldera. As a topographic barrier, it directed ash flows eastward over its southern pyroclastic apron and northward over its western rhyolite ridge, but it had no bearing on evacuation of the Bishop Tuff magma reservoir. Ignimbrites in all directions contain the full array, in highly varied proportions, of pumice and crystal types, while both northern and southeastern sectors are rich in lithic fragments of Glass Mountain rhyolite.

Lifetime of the Bishop Magma Chamber. Previous estimates of the precaldera time span that elapsed during assembly and growth of the melt-dominant magma chamber ranged from more than a million years to only a few thousand, as reviewed by Chamberlain and others (2014a). Ion microprobe $\mathrm{U}-\mathrm{Pb}$ ages for hundreds of Bishop Tuff zircons representing all packages range continuously from $\sim 845$ to $767 \mathrm{ka}$, suggesting a longevity of $\sim 80,000$ years (Chamberlain and others, 2014a). As zircon was the earliest phase to crystallize, occurring as inclusions in all other phenocryst species, it is unlikely that the upper-crustal magma body significantly predated $845 \mathrm{ka}$. The texturally coherent suite of 845 to $767 \mathrm{ka}$ Bishop Tuff zircons was readily distinguished from sparse zircons inherited from Glass Mountain and from Mesozoic roof rocks. The magmatic history of 100-km³ Glass Mountain (Metz and Mahood, 1985, 1991), including $\sim 35$ eruptions of rhyolite nearly identical to the Bishop Tuff during the 400,000-year interval 1.2-0.8 Ma, suggests that assembly of the $650-\mathrm{km}^{3}$ Bishop Tuff magma volume in only several thousand years is unlikely.

Late-stage intrusion and mixing of batches of the slightly hotter "bright-rim magma" (enriched in $\mathrm{Ti}, \mathrm{Ba}, \mathrm{Sr}$, and $\mathrm{CO}_{2}$ ) began as long as 10,000 years before eruption, as indicated by
$\mathrm{U}-\mathrm{Pb}$ ages of bright rims and contiguous interiors in zircons (Chamberlain and others, 2014a). Textural and compositional effects of the "bright-rim" magma injections have sometimes been conflated with features attending formation of the chamber itself. Such recharge and mixing may have continued until $\sim 500$ years or less before eruption, as suggested by diffusion chronometry on "bright rims" in sanidine (Chamberlain and others (2014b).

Confusion about Melt Inclusions. Based on compositions of melt inclusions (MI) in the interior of quartz grains, Gualda and Ghiorso (2013) suggested that crystallization of early and late parts of the Bishop Tuff sequence took place from melts of similar composition at essentially the same temperature and pressure. All such MI were entrapped prior to late-stage introduction of the less evolved, higher temperature, "bright-rim" magma, which caused marginal resorption of quartz and sanidine and subsequent overgrowth of rims that are enriched in $\mathrm{Ti}, \mathrm{Ba}$, and $\mathrm{Sr}$ and that contain $\mathrm{MI}$ enriched in those elements and $\mathrm{CO}_{2}$. Models based on the compositions of $\mathrm{MI}$ in quartz cores ignores data from $\mathrm{MI}$ in their own rims. The elevated $\mathrm{CO}_{2}$ of "bright-rim" MI, mostly (but not exclusively) in later-erupted Ig2 packages, requires higher entrapment pressures than for $\mathrm{CO}_{2}$-poor $\mathrm{MI}$ in early and middle parts of the eruptive sequence (Wallace and others, 1999; Roberge and others, 2013). See section, above, on $\mathrm{H}_{2} \mathrm{O}$ and $\mathrm{CO}_{2}$ gradients. Because some "bright rims" are as thick as $300 \mu \mathrm{m}$, amounting to as much as half the crystal volume, the rims are unlikely to have grown rapidly, as discussed by Chamberlain and others (2014b) and Evans and others (2016). Because resorption surfaces, inboard of the "bright rims," indicate reheating of interior MI, their compositions were probably modified. Indeed, a strong case has been made (Wallace and others, 1999; Roberge and others, 2013) that such inboard MI, within "bright-rimmed" crystals, gained $\mathrm{SiO}_{2}$ from their hosts and lost $\mathrm{Na}, \mathrm{Li}$, and $\mathrm{H}$ (thus $\mathrm{H}_{2} \mathrm{O}$ ) diffusively. The interior $\mathrm{MI}$ are thus unreliable for estimating entrapment pressure, and only the unmodified, post-reheating MI in the rims themselves record conditions during entrapment.

Incremental Assembly of the Zoned Chamber. After failure of earlier speculative models (Hildreth, 1979, 1981) that sought to explain the compositional zoning of the Bishop Tuff magma reservoir, decades of work far more extensive than my thesis reconnaissance (Hildreth, 1977, 1979) led me to elaborate upon the model of secular incremental growth of the chamber (Hildreth, 2004; Hildreth and Wilson, 2007). It is now widely accepted that caldera-related, great volumes of high-silica rhyolitic melt must have separated from a subjacent pluton-scale reservoir of granitic (quartz-feldspar) crystal mush at least an order of magnitude more voluminous than the melt extracted, as depicted in figure 7 of Hildreth (2004) and figure 18 of Hildreth and Wilson (2007).

Analogous to leucogranitic melts segregating as dikes from mushy granitoid plutons, it was proposed that countless batches of crystal-poor rhyolitic melt ascended one by one from melt lenses that segregated within a large underlying reservoir of granitic crystal mush, contiguous with the 
melt-dominant chamber. During progressive growth of the upper-crustal chamber, each melt batch should have risen to its appropriate level in the melt-buoyancy gradient, which was controlled principally by gradients in dissolved water and exsolved gas bubbles and which was gravitationally stable and thus self-sustaining against convective homogenization.

The range in melt compositions so assembled would have been produced by crystal-melt fractionation, not in the chamber but in the subjacent mush reservoir by episodic extraction of variably evolved batches. It was within the compositionally zoned melt column, secularly assembled as the subcaldera chamber, that the vertically zoned suite of unzoned phenocrysts crystallized, resulting in a crystallinity gradient from phenocryst-poor, water-rich magma above to phenocryst-rich magma with less water and more $\mathrm{CO}_{2}$ below. The late-stage "bright-rim" magma batches continued the same process, though by then the new batches consisted of slightly hotter, less evolved rhyolite (richer in $\mathrm{Ti}, \mathrm{Ba}, \mathrm{Sr}$, and $\mathrm{CO}_{2}$ ) that ascended as plumes from deeper in (or perhaps from beneath) the mush reservoir, introducing pyroxene phenocrysts and promoting marginal resorption of resident quartz and sanidine. Although some "bright rim" batches apparently mingled with zoned resident magma (leading to inhomogeneous swirly pumice), arrival of the many later batches took place soon enough before the caldera-forming eruption that at least some failed to blend smoothly into the secularly organized gradient.

Suggestions have been made recently that some compositionally heterogeneous caldera-forming eruptions could represent evacuation of laterally discrete magma bodies or of several variably connected melt lenses stored vertically or laterally within a partially to fully crystalline framework (Cashman and Giordano, 2014; and references therein). The stacked model is feasible for mafic sill complexes and possibly for storage beneath stratovolcanoes of intermediate composition, but I am not aware of any voluminous caldera-forming ignimbrite eruption for which a withdrawal model tapping discrete silicic magma lenses is convincing.

Among Long Valley rhyolites, there were several episodes during which a series of melt lenses may have segregated within and ascended from large reservoirs of granitic crystal mush. (1) During the first half of the Glass Mountain activity (2.2-1.3 Ma), about 24 eruptions of crystal-poor, high-silica rhyolite were spread widely in time and varied unsystematically in trace-element composition (Metz and Mahood, 1985, 1991). Their total volume may have been as much as $\sim 50 \mathrm{~km}^{3}$, but few individual eruptions were as big as $1 \mathrm{~km}^{3}$. (2) The later interval at Glass Mountain (1.2-0.8 Ma) produced $\sim 35$ crystal-poor, high-silica rhyolite, eruptive units that were all mutually similar in trace- and major-element composition. These 35 units were also almost identical to the early-erupted, crystal-poor pumice of the Bishop Tuff, and they could have represented episodic tapping of a growing upper-crustal chamber rather than sporadic extracts directly from deep plutonic mush. (3) An unknown number of batches of crystal-poor, compositionally varied, high-silica rhyolite ascended to the upper crust ( 845-767 ka; Chamberlain and others, 2014a) to assemble the Bishop Tuff chamber $\left(>650 \mathrm{~km}^{3}\right)$, construction of which produced a gradient in melt composition and, later, a gradient in crystallinity. (4) The early postcaldera rhyolite consists of at least 14 batches of crystal-poor highsilica rhyolite that erupted episodically over a 110-k.y. interval (750-640 ka). Total volume is $\sim 100 \mathrm{~km}^{3}$, but most of the units exposed are only $0.5-2 \mathrm{~km}^{3}$. The 14 exposed batches are nearly identical in major-element composition, but they range widely in trace-element composition (Hildreth and others, 2017). (5) The nearby Mono Craters chain provides yet another example: about 30 modest batches of phenocryst-poor, high-silica rhyolite, varied in trace elements, segregated from a pluton-scale granitic reservoir, ascended, and erupted episodically over the past 60 k.y.

Each of these rhyolitic sequences involved numerous batches of nearly aphyric minimum melt that were almost identical in major-element composition but had unsystematic variations in trace-element composition. All episodes were spread out over tens of thousands of years or much longer. None brought up significant amounts of refractory or xenocrystic crystals, let alone any clots or fragments of crystalline septa that might have enveloped stacked melt lenses. The Bishop Tuff (and perhaps late-stage Glass Mountain) represented melt-separation episodes when successively ascending rhyolitic melt batches were assembled into an upper-crustal chamber, rather than erupting piecemeal as in the other episodes cited.

It is hard to reconcile $2-3 \mathrm{~km}$ of roof-plate subsidence, a smoothly bounded elliptical caldera, a single unbroken fallout sequence, systematic evacuation of a reservoir graded in composition and crystal content, a smooth positive $\mathrm{T}-\mathrm{fO}_{2}$ curve, and absence of fragments of crystalline envelopes with a reservoir model of discretely distributed or stacked melt lenses. The recent work of Chamberlain and others (2014a, b; 2015) reaffirmed the unitary nature of the zoned Bishop Tuff magma chamber as worked out by Hildreth and Wilson (2007). Numerous melt lenses indeed fed growth of the chamber, but not the eruption.

\section{Acknowledgments}

My bedrock gratitude remains to the late great Ian Carmichael for motivating my petrologic investigation of the Bishop Tuff, which in 1973-1977 we considered a detailed study but which turned out to be a pioneering reconnaissance. Partnering with Colin Wilson in the 1990s stretched us both and transformed understanding of the Bishop Tuff. Geologists always benefit from the work of those who have gone before, so I am pleased to acknowledge seminal work on the Bishop Tuff by Charles M. Gilbert, Paul Bateman, and Mike Sheridan. Important recent contributions were made by Fred Anderson, Katy Chamberlain, Bernard Evans, Gail Mahood, Vicki McConnell, Jenny Metz, and Paul Wallace. Judy Fierstein has been an integral and indispensable part of my field investigations for 37 years. The hospitality and companionship of Sally and Bob 
Drake of Old Mammoth have been mainstays of our latest decade of fieldwork at Long Valley. Helpful reviews by Allen Glazner, Anita Grunder, Erik Klemetti, and Claire Landowski improved the presentation.

\section{References Cited}

Bacon, C.R., and Hirschmann, M. M., 1988, Mg/Mn partitioning as a test for equilibrium between coexisting $\mathrm{Fe}-\mathrm{Ti}$ oxides: American Mineralogist, v. 73, p. 57-61.

Bailey, R.A., 1989, Geologic map of Long Valley caldera, Mono-Inyo Craters volcanic chain, and vicinity, eastern California: U.S. Geological Survey Map I-1933, 2 sheets, scale 1:62,500, pamphlet $11 \mathrm{p}$.

Bindeman, I.N., and Valley, J.W., 2002, Oxygen isotope study of the Long Valley magma system, California-Isotope thermometry and convection in large silicic magma bodies: Contributions to Mineralogy and Petrology, v. 144, p. 185-205.

Cashman, K.V., and Giordano, G., 2014, Calderas and magma reservoirs: Journal of Volcanology and Geothermal Research, v. 288, p. 28-45.

Chamberlain, K.J., Morgan, D.J., and Wilson, C.J.N., 2014b, Timescales of mixing and mobilisation in the Bishop Tuff magma body - Perspectives from diffusion chronometry: Contributions to Mineralogy and Petrology, v. 168, no. 1, p. $1-24$.

Chamberlain, K.J., Wilson, C.J.N., Wooden, J.L., Charlier, B.L.A., and Ireland, T.R., 2014a, New perspectives on the Bishop Tuff from zircon textures, ages, and trace elements: Journal of Petrology, v. 55, p. 395-426.

Chamberlain, K.J., Wilson, C.J.N., Wallace, P.J., and Millet, M.-A., 2015, Micro-analytical perspectives on the Bishop Tuff and its Magma Chamber: Journal of Petrology, v. 56, no. 3 , p. $605-640$.

Evans, B.W., and Bachmann, O., 2013, Implications of equilibrium and disequilibrium among crystal phases in the Bishop Tuff: American Mineralogist, v. 98, p. 271-274.

Evans, B.W., Hildreth, W., Bachmann, O., and Scaillet, B., 2016, In defense of magnetite-ilmenite thermometry in the Bishop Tuff and its implication for gradients in silicic magma reservoirs: American Mineralogist, v. 101, p. 469-482.

Frost, B.R., and Lindsley, D.H., 1992, Equilibria among Fe-Ti oxides, pyroxenes, olivine, quartz, Part II, Application: American Mineralogist, v. 77, p. 1004-1020.
Ghiorso, M.S., and Evans, B.W., 2008, Thermodynamics of rhombohedral oxide solid solutions and a revision of the Fe-Ti two-oxide geothermometer and oxygen-barometer: American Journal of Science, v. 308, no. 9, p. 957-1039.

Gilbert, C.M., 1938, Welded tuff in eastern California: Geological Society of America Bulletin, v. 49, p. 1829-1862.

Gualda, G.A.R., and Ghiorso, M.S., 2013, The Bishop Tuff giant magma body - an alternative to the standard model: Contributions to Mineralogy and Petrology, v. 166, p. 755-775.

Hervig, R.L., and Dunbar, N.W., 1992, Cause of chemical zoning in the Bishop (California) and Bandelier (New Mexico) magma chambers: Earth and Planetary Science Letters, v. 111, p. $97-108$.

Hildreth, W., 1977, The magma chamber of the Bishop TuffGradients in pressure, temperature, and composition: Berkeley, University of California, Ph.D. dissertation, 328 p.

Hildreth, W., 1979, The Bishop Tuff-Evidence for the origin of compositional zonation in silicic magma chambers in Chapin, C.E., and Elston, W.E., eds., Ash-flow tuffs: Geological Society of America Special Paper, v. 180, p. 43-75.

Hildreth, W., 1981, Gradients in silicic magma chambers: implications for lithospheric magmatism: Journal of Geophysical Research, v. 86, p. 10153-10192.

Hildreth, W., 2004, Volcanological perspectives on Long Valley, Mammoth Mountain, and Mono Craters-several contiguous but discrete systems: Journal of Volcanology and Geothermal Research, v. 136, p. 169-198.

Hildreth, W., and Fierstein, J., 2016, Long Valley Caldera lake and reincision of Owens River Gorge: U.S. Geological Survey Scientific Investigations Report 2016-5120, 63 p.

Hildreth, W., Fierstein, J., and Calvert, A., 2017, Early postcaldera rhyolite and structural resurgence at Long Valley caldera, California: Journal of Volcanology and Geothermal Research, v. 335, p. 1-34.

Hildreth, W., and Mahood, G.A., 1986, Ring-fracture eruption of the Bishop Tuff: Geological Society of America Bulletin, v. 97 , p. $396-403$.

Hildreth, W., and Wilson, C.J.N., 2007, Compositional zoning of the Bishop Tuff: Journal of Petrology, v. 48, p. 951-999.

Metz, J.M., and Bailey, R.A., 1993, Geologic map of Glass Mountain, Mono County, California: U.S. Geological Survey Map I-1995, scale 1:24,000.

Metz, J.M., and Mahood, G.A., 1985, Precursors to the Bishop Tuff eruption-Glass Mountain, Long Valley, California: Journal of Geophysical Research, v. 90, p. 11121-11126. 
Metz, J.M., and Mahood, G.A., 1991, Development of the Long Valley, California, magma chamber recorded in precaldera rhyolite lavas of Glass Mountain: Contributions to Mineralogy and Petrology, v. 106, p. 379-397.

Peppard, B.T., Steele, I.M., Davis, A.M., Wallace, P.J., and Anderson, A.T., 2001, Zoned quartz phenocrysts from the rhyolitic Bishop Tuff: American Mineralogist, v. 86, p. 1034-1052.

Roberge, J., Wallace, P.J., and Kent, A.J.R., 2013, Magmatic processes in the Bishop Tuff rhyolitic magma based on trace elements in melt inclusions and pumice matrix glass: Contributions to Mineralogy and Petrology, v. 165, no. 2, p. 237-257.

Sheridan, M.F., 1970, Fumarolic mounds and ridges of the Bishop Tuff, California: Geological Society of America Bulletin, v. 81, p. 851-868.

Wallace, P.J., Anderson Jr., A.T., and Davis, A.M., 1999, Gradients in $\mathrm{H} 2 \mathrm{O}, \mathrm{CO} 2$, and exsolved gas in a large-volume silicic magma system - interpreting the record preserved in melt inclusions from the Bishop Tuff: Journal of Geophysical Research, v. 104, B9, p. 20097-20122.

Wark, D.A., Hildreth, W., Spear, F.S., Cherniak, D.J., and Watson, E.B., 2007, Pre-eruption recharge of the Bishop magma system: Geology, v. 35, p. 235-238.

Wilson, C.J.N., and Hildreth, W., 1997, The Bishop TuffNew insights from eruptive stratigraphy: Journal of Geology, v. 105, p. 407-439. 



\section{Concealed Ring-Fault Zone of Long Valley Caldera}

By Wes Hildreth 


\title{
Concealed Ring-Fault Zone of Long Valley Caldera
}

\author{
By Wes Hildreth
}

\section{Abstract}

The steep topographic wall of Long Valley Caldera is commonly mistaken for its structural boundary. The ringfault zone, within which the roof plate of the evacuating magma chamber subsided, lies $1-4 \mathrm{~km}$ inboard of the wall and encloses an area only half as large as the modern physiographic depression. Because the ring faults are everywhere buried by postcaldera fill, it is natural to ask where the structural boundary actually lies. Here we review evidence provided by geophysical surveys, drillhole data, landslide masses, seismically defined cryptic fault planes, and locations of postcaldera volcanic vents to help locate the circum-subsidence ring-fault zone. Sets of nested ring faults, generally inclined steeply inboard, are inferred. Improved definition of the width and dip of the ring-fault zone could be gained by further drilling, which uniquely provides hard evidence about the unexposed subsurface. The complex stratigraphy and structure beneath the caldera's west moat are significantly reinterpreted.

\section{Introduction}

Long Valley Caldera is an elliptical depression 17 by $31 \mathrm{~km}$ across (fig. 1) that collapsed during the 767-ka eruption of $650 \mathrm{~km}^{3}$ of rhyolite magma that formed the Bishop Tuff. Evacuation of the magma chamber resulted in $2-3 \mathrm{~km}$ subsidence of a roof plate that consisted of Paleozoic metasedimentary strata and subordinate Mesozoic granitoid plutons (Bailey, 1989). The caldera straddles the rangefront boundary between the Sierra Nevada microplate and the extended terrain of the Basin-and-Range Province. The rhyolite magma body had accumulated at a $15-\mathrm{km}$ left-stepping offset in the Sierran rangefront fault system, which we infer on tectonostratigraphic evidence to have initiated around Long Valley at about 2.5 Ma. In drillholes, the intracaldera Bishop Tuff is widely as thick as $1-1.5 \mathrm{~km}$, and it has been covered by $0.5-1 \mathrm{~km}$ of younger fill-principally lake sediments, tuffs, and lavas.

The caldera wall is well defined everywhere except along the low southeast margin where postcaldera sediment has filled the caldera to its rim. The precaldera Glass Mountain edifice on the northeast (Metz and Bailey, 1993) and the Morrison block of the Sierra Nevada on the south (Greene and Stevens, 2002) still display imposing caldera walls more than $1,000 \mathrm{~m}$ high. The north wall, which consists of precaldera volcanic rocks atop pre-Cenozoic basement, is $800 \mathrm{~m}$ high in the east, gradually declining westward to $\sim 300 \mathrm{~m}$ between
Clark Canyon and Crestview, where precaldera streams had flowed south into the later site of the caldera (Hildreth and Fierstein, 2016b). The west wall is $500 \mathrm{~m}$ high at granitic White Wing Mountain and maintains a 400-500-m-high scarp of Pliocene volcanic rocks atop basement rocks as far south as a low saddle at Minaret Summit. From there, the caldera wall climbs southeastward beneath the late Pleistocene Mammoth Mountain volcanic edifice toward a 500-m caldera-wall scarp of basement rocks near Mammoth Rock (fig. 1).

Uplift of the west-central part of the caldera raised a 10-km-wide resurgent structure by more than $400 \mathrm{~m}$ (fig. 1). Structural resurgence began after intracaldera eruption of much of the multiphase $100-\mathrm{km}^{3}$ early rhyolite $(750-640 \mathrm{ka})$, overlapped in time with its final eruptions, and outlasted it. Most of the uplift was complete by $570 \mathrm{ka}$, having taken place over 100 kyr (Hildreth and others, 2017). Raising of the intracaldera swell left an annular lowland moat surrounding it. Separating the domical uplift from the caldera walls, the moat is where the ring-fault zone is concealed by younger caldera fill.

In contrast to the clearly defined topographic walls, the structural ring-fault zone is nowhere exposed. It is important to locate the buried ring-fault zone in order to (1) avoid exaggeration of the area of structural subsidence; (2) more accurately estimate volumes of intracaldera Bishop Tuff and younger fill; (3) site wells to be drilled for scientific or geothermal exploration; and (4) distinguish postcaldera ring vents from others. The caldera depression owes its modern dimensions and the physiography of its walls to large-scale syneruptive slumping (Lipman, 1997; Suemnicht and others, 2006) and to subsequent erosion. Inferences based on gravity surveys, drillholes, seismic refraction profiles, and postcaldera vent distribution inform our estimates of ring-fault location (Kane and others, 1976; Hill, 1976; Hill and others, 1985; Carle, 1988; Suemnicht and Varga, 1988; Bailey, 1989; Hildreth, 2004; Hildreth and Fierstein, 2016a), none of which is fully satisfactory. Such estimates approximate the area of deep structural collapse as an oval 12 by $22 \mathrm{~km}$ across $\left(\sim 210 \mathrm{~km}^{2}\right)$, which is only half of the $\sim 420-\mathrm{km}^{2}$ floor of the topographic caldera depression (fig. 1). The step-faulted ring-fault zone itself underlies $30-40$ percent of the area, whereas $\sim 10-15$ percent of the basin floor lies outside it (fig. 1). The magma chamber is likely to have been at least a little wider than the roof plate that sank into it.

The following discussion reexamines the evidence for ring-fault location and presents a revised analysis of the complex subsidence structure concealed beneath the caldera's west moat. 


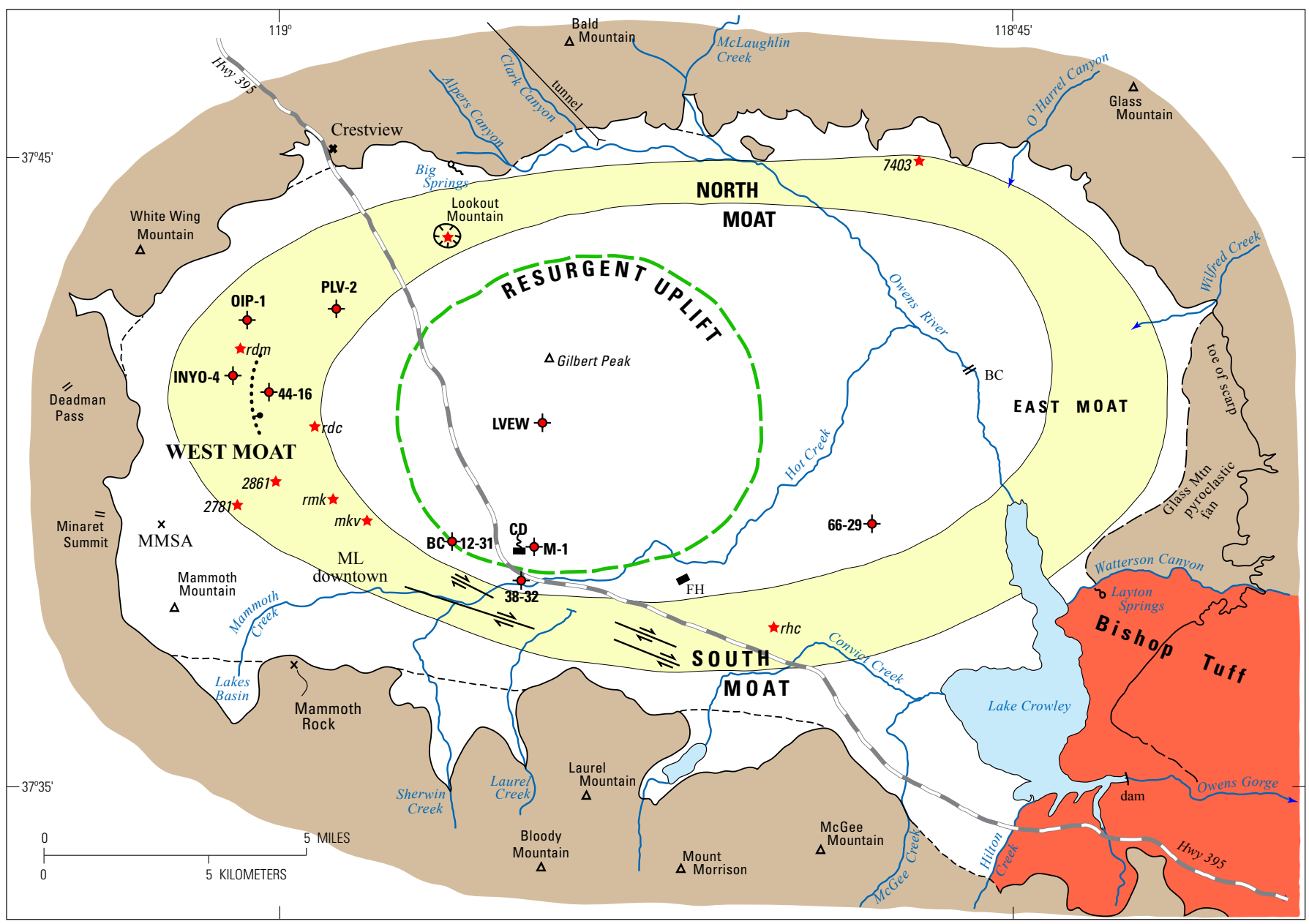

Figure 1. Outline map of Long Valley Caldera, emphasizing its topographic wall, resurgent uplift, and structural ring-fault zone (yellow) between them. Precaldera rocks (brown), Cambrian to Pleistocene, form steep walls around 90 percent of the caldera periphery. To the southeast, Bishop Tuff ignimbrite outflow (red) filled the wide valley of precaldera Owens River, which had drained across the eastern part of the subsequent site of the caldera, from Clark Canyon into Neogene Owens River Gorge. Dashed lines crossing caldera-wall embayments are meant to suggest continuity of basement rocks concealed beneath modern surficial deposits. Four concealed faults in south moat were inferred from seismicity (Prejean and others, 2002). Star symbols mark vents for selected postcaldera eruptive units, conduits of which may have been influenced by the ring-fault zone: mkv, andesite of Knolls Vista; rdc, Dry Creek dome; rdm, Deer Mountain; rhc, Hot Creek flow; rmk, Mammoth Knolls dome; and Domes 2861, 2781, and 7403. Nine drillholes are identified: in south moat, M-1, 38-32, and BC 12-31 penetrated large slide masses of caldera-wall basement rocks that rest on intracaldera Bishop Tuff. In 3 -km-deep LVEW, $1.2 \mathrm{~km}$ of Bishop Tuff is overlain by $622 \mathrm{~m}$ of younger rocks and has been updomed $\sim 400 \mathrm{~m}$ by structural resurgence (Hildreth and others, 2017). In 66-29, $>1.5 \mathrm{~km}$ of Bishop Tuff is overlain by $700 \mathrm{~m}$ of tuffaceous lake sediment. Wells 44-16, Inyo-4, 0IP-1, and PLV-2 are also discussed in text (and in Hildreth and Fierstein, 2016a). Abbreviations: BC, Benton Crossing road bridge; CD, Casa Diablo geothermal plant; FH, fish hatchery; ML, town of Mammoth Lakes; MMSA, Mammoth Mountain Ski Area (Main Lodge). Lake Crowley is a reservoir, dating from closure of Long Valley Dam in 1941, not a remnant of the middle Pleistocene caldera lake, which ultimately overflowed through the same outlet into Owens River Gorge (Hildreth and Fierstein, 2016b). 


\section{Constraints on Locations of the Ring- Fault Zone}

\section{North Moat}

The foot of the north wall trends straight east-west for $13 \mathrm{~km}$ from O'Harrel Canyon to Clark Canyon (fig. 1). Granitic and metasedimentary rocks crop out almost continuously along the base of the wall. A few granitic spurs that extend south from the foot of the wall and a few granitic knolls surrounded by alluvial fan gravels indicate that the ring-fault zone begins at least $1 \mathrm{~km}$ south of the topographic escarpment. Dome 7403 (2,256 m; 68 percent $\mathrm{SiO}_{2}$; hornblende-plagioclase rhyodacite), which is younger than $150 \mathrm{ka}$ (Hildreth and Fierstein, 2016b), was extruded only slightly inboard of the noses of two of the prominent granitic spurs that flank the dome (fig. 1). Its conduit is likely to have taken advantage of the ring-fault zone, rather than intruding basement rocks just outboard of it. A north-south cross section through a three-dimensional gravity model (fig. 8 of Carle, 1988) shows nested ring faults beginning directly beneath Dome 7403 , downstepping the caldera floor, first by $\sim 1 \mathrm{~km}$ and then, $2 \mathrm{~km}$ farther inboard (south), by as much as $3 \mathrm{~km}$, where the fill reaches its maximum thickness. Seismic refraction data were likewise interpreted to suggest an inboarddipping ring-fault zone $\sim 2 \mathrm{~km}$ wide along the north moat. A north-south refraction profile just south of Bald Mountain, $10 \mathrm{~km}$ west of Dome 7403, portrays the caldera floor downstepped only $1.4 \mathrm{~km}$ (fig. 12 of Hill and others, 1985), whereas in another profile $\sim 2 \mathrm{~km}$ still farther west, near Alpers Canyon, the 2-km-wide inward-dipping fault zone was thought to step down the caldera-floor basement rocks by as much as $3 \mathrm{~km}$ (fig. 8 of Hill, 1976).

\section{East Moat}

From O'Harrel Canyon southeast to Wilfred Canyon, a 7-km stretch of the caldera's steep east wall consists of the Glass Mountain rhyolite edifice (2.2-0.8 Ma) with a few small granitic exposures along its toe. From Wilfred Canyon south to Lake Crowley, the next 9-km-long reach of the wall consists of the Glass Mountain pyroclastic apron and minor Pliocene basalt, both overlying Mesozoic granodiorite. A large apron of alluvial fans extends 3-4 km west from the toe of the wall, lapping out over silty lakebeds of the middle Pleistocene caldera lake and obscuring any surface evidence that might help locate the ring-fault zone. The array of small faults depicted by Bailey (1989) across the alluvial apron cannot be verified, and there are no postcaldera volcanic vents in the eastern Long Valley lowland to constrain ringfault location. Gravity models for the east moat (figs. 9, 10 of Carle, 1988) depict (beneath the alluvial apron) a ring-fault zone 3-4 km wide in which nested faults step the caldera floor down beneath fill thicknesses as great as $2.5-3 \mathrm{~km}$. Likewise, a refraction profile across the concealed structural margin west of Watterson Canyon (fig. 7 of Hill, 1976) depicts a 4-km-wide ring-fault zone and westward tilting of the subsided roof plate, such that the caldera floor is deepest and the fill thickest $(2.5-3 \mathrm{~km})$ as far as $6 \mathrm{~km}$ inboard. Extracaldera Bishop Tuff is exposed at Layton Springs and along the southeastern shore of Lake Crowley, so the concealed ring faults must cross beneath the north arm of Lake Crowley (fig. 1). From there, the ring-fault zone apparently swings southwestward toward the vent for the Hot Creek rhyolite coulee (unit rhc, fig. 1), which lies $3 \mathrm{~km}$ inboard of the caldera's topographic wall below McGee Mountain.

The southeast bight of the Long Valley lowland, which is now occupied by Lake Crowley reservoir, is not a structural scallop of the caldera margin, as most of it is bounded and floored shallowly by Bishop Tuff. Only a few kilometers farther north, the Bishop Tuff is buried by $700 \mathrm{~m}$ of intracaldera sediments. Uniquely around the caldera perimeter, no topographic wall is exposed at Lake Crowley because the lake occupies the precaldera valley of the Owens River, which flowed from the modern site of Mono Basin southeast across the later site of the caldera into Neogene Owens River Gorge (Hildreth and Fierstein, 2016b).

\section{South Moat}

The concealed ring-fault zone is better located along the south moat (fig. 2) thanks to four independent lines of evidence. The steep gravity gradient begins abruptly $\sim 1 \mathrm{~km}$ north of the toe of the topographic wall (figs. 6-8 of Carle, 1988), and it slopes or steps steeply inboard (northward). Brecciated landslide masses of caldera-wall basement rocks, 40-120 m thick and now covered by $325-625 \mathrm{~m}$ of younger fill, rest directly upon the Bishop Tuff in three different drill holes near and west of the Casa Diablo geothermal plant (Suemnicht and others, 2006). The drill sites are 2.5-3 km north of the topographic wall, and the slide masses lie inboard of the ring-fault zone where the intracaldera Bishop Tuff abruptly thickens to $>1,000 \mathrm{~m}$. High-resolution hypocenter relocations for thousands of earthquakes identified two pairs of (unexposed) steeply north-dipping dextral strike-slip faults beneath the south moat (fig. 1) - one pair near Casa Diablo, the other $\sim 5 \mathrm{~km}$ east, south of the fish hatchery (figs. 5, 6 of Prejean and others, 2002). The earthquakes are distributed continuously from 2 to $9 \mathrm{~km}$ deep, the faults trend west-northwest, and the outboard member of each pair defines the south limit of seismicity in the south moat, 1.5-2.5 km north of the exposed toe of the basement rocks in the caldera wall. Ongoing tectonically driven shear, modulated by hydrothermal fluid pressure, is probably making use of the kilometer-wide ring-fault shear zone and its deeper extension along what had been the precaldera south wall of the Bishop Tuff magma reservoir. The west-northwest trend thus inferred for the south moat ring-fault zone projects eastward toward the vent of the 333-ka 


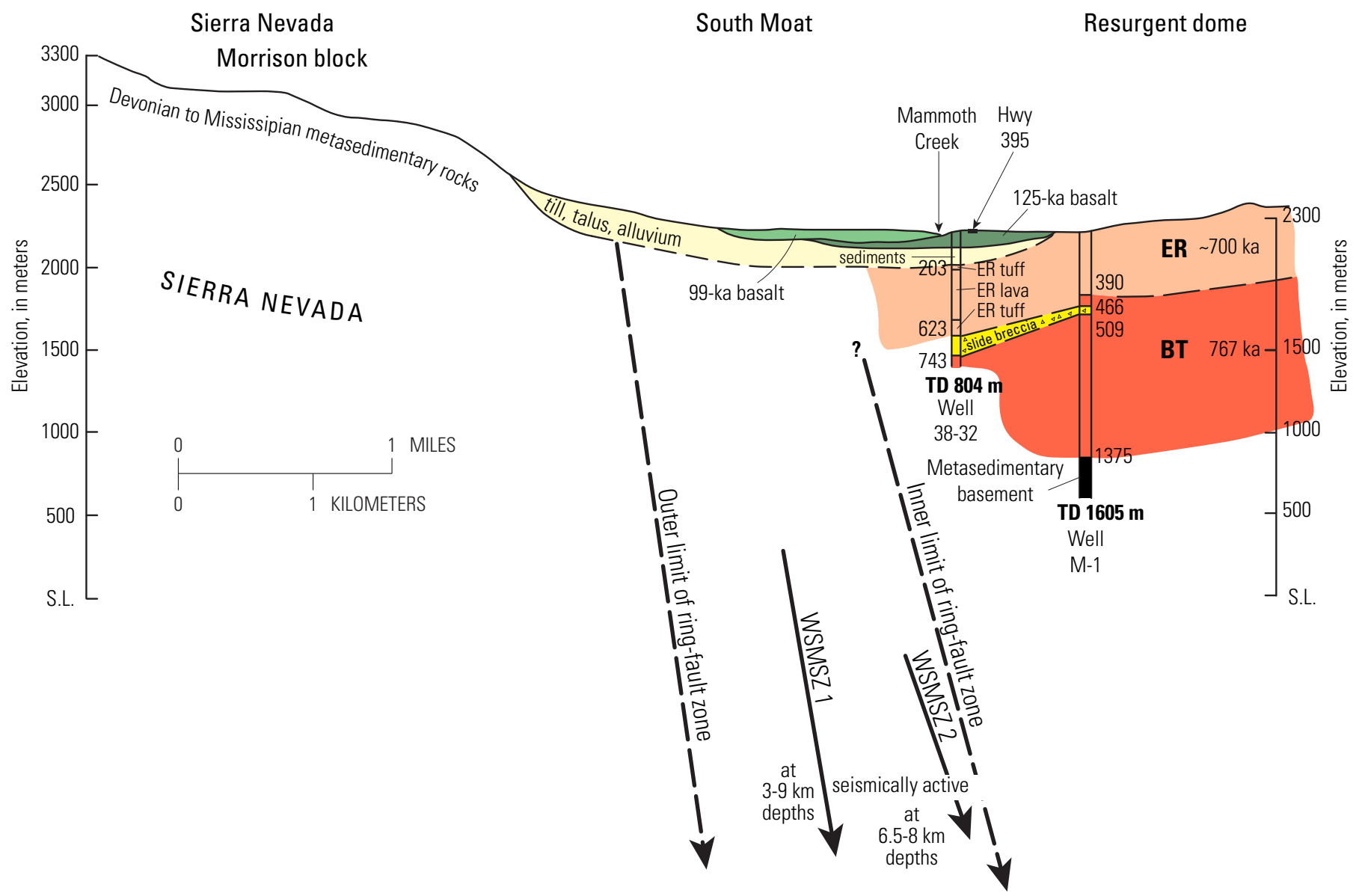

Figure 2. Generalized north-south interpretive section across south moat of Long Valley Caldera, between Casa Diablo geothermal area and Sierran slope of Laurel Mountain, inferred from seismic and drillcore data. Vertical exaggeration $x$ 1.2. Geothermal exploration well $\mathrm{M}-1$ is within the compound of the operating geothermal plant. Well 38-32 is on the north side of Mammoth Creek. TD, total depth of wells; elevations of some contacts in the cores are shown. Probable limits of south moat ring-fault zone are shown, as are a pair of cryptic fault planes (WSMSZ 1 and 2) within the zone that were defined by high-resolution relocation of thousands of recent earthquakes by Prejean and others (2002). Both faults are most active at depths greater than the section, and the outer one provides the southern limit of intense south moat seismicity in recent decades. Arrows indicate that the faults extend to depths far greater than the diagram. Both the intracaldera Bishop Tuff (BT) and the overlying early postcaldera rhyolite (ER) were domed at least $400 \mathrm{~m}$ upward between $\sim 700$ and $\sim 570 \mathrm{ka}$. Present-day surface of the structural uplift extends to an elevation as high as 2,619 $\mathrm{m}$ a few kilometers north of the south moat. For a section of the entire resurgent structure, see figure 15 of Hildreth and others (2017).

Hot Creek rhyolite flow (unit rhc, fig. 1) and westward toward the 160-85 ka vent cluster (fig. 1) that includes Knolls Vista (mkv), Mammoth Knolls (rmk), and the off-edifice Mammoth Mountain system Domes 2861 and 2781 (Hildreth and Fierstein, 2016a).

\section{Mammoth Mountain}

The 4- $\mathrm{km}^{3}$ trachydacite center called Mammoth Mountain consists of 25 separate eruptive units (63-71 percent $\mathrm{SiO}_{2}$ ), most of which piled up to build a 900-m-high edifice that banks against an inward-sloping glaciated wall of basement rocks (Hildreth and others, 2014). The edifice is outside the ring-fault zone, but two off-edifice domes of similar trachydacite apparently extruded from conduits within the zone.
Domes 2781 and 2861 (fig. 1), a few kilometers northeast of the edifice, are the oldest (100-87 ka) of the 25 Mammoth Mountain eruptive units exposed. The other 23 that built the edifice have ${ }^{40} \mathrm{Ar} /{ }^{39} \mathrm{Ar}$ ages that extend from $87 \mathrm{ka}$ to $50 \mathrm{ka}$. Previous publications have referred to Mammoth Mountain as located on the caldera's southwest margin, so it needs to be clarified that the edifice is banked against the recessional topographic margin but lies well outside the structural (ringfault) margin.

\section{West Moat}

In contrast to the south moat, seismicity in the west moat is minimal. The few exposed faults that cut the west moat fill are generally north-striking and have observable 
displacements of at most a few meters (Bailey, 1989; Hildreth and Fierstein, 2016a). Inferences from drillhole data and from the caldera's overlap with the precaldera rangefront fault system, however, suggest that complex structures are buried beneath the west moat.

Well data show that the thickness of early postcaldera rhyolite beneath the caldera's west moat ranges widely, from only $342 \mathrm{~m}$ in Inyo- 4 to $537 \mathrm{~m}$ in $44-16$ (fig. 3). The base of the early rhyolite lies at elevations of $1,809 \mathrm{~m}$ asl in Inyo-4, and at $1,535 \mathrm{~m}$ asl in 44-16. In two additional wells nearby, the base of the early rhyolite lies at intermediate depths, at $1,739 \mathrm{~m}$ asl in OIP-1 and deeper than 1,722 $\mathrm{m}$ asl in PLV-2 (fig. 1; Hildreth and Fierstein, 2016a). Basal elevations of the early rhyolite thus differ by $274 \mathrm{~m}$ in wells less than $1 \mathrm{~km}$ apart (fig. 3). More surprising, the Bishop Tuff was found to be only $253 \mathrm{~m}$ thick in well 44-16, compared to $>1,000 \mathrm{~m}$ farther east, and it was not found at all in wells Inyo-4 and OIP-1, both of which, as logged, appeared to have bottomed in what were presumed to be pre-Cenozoic basement rocks, which were encountered at elevations of 1,746 $\mathrm{m}$ and 1,736 $\mathrm{m}$ asl, respectively (fig. 3; Hildreth and Fierstein, 2016a). The unexpectedly thin intracaldera ignimbrite in well 44-16 was first reported by Suemnicht (1987), who inferred that the Bishop Tuff had draped over significant caldera-floor topography.

On the basis of the well data, mapping of surface faults and lineaments, and inference of a precaldera embayment in the left-stepping rangefront, Suemnicht and Varga (1988) offered a complex hypothetical model of west moat structure. They emphasized that the top of the pre-Cenozoic basement in well 44-16, at an elevation of $816 \mathrm{~m}$ asl, is $930 \mathrm{~m}$ deeper than it appears to be in nearby Inyo-4. They also pointed out that the base of a thick stack of Pliocene volcanic rocks beneath the Bishop Tuff in 44-16 (fig. 3) is 1.5-1.9 km lower in elevation than the same horizon on the caldera's west wall, only 4 $\mathrm{km}$ away. They inferred (and we concur) that only part of this vertical displacement resulted from caldera subsidence and that part of it represents precaldera rangefront faulting (which our mapping [Hildreth and Fierstein, 2016a] indicates began in the Long Valley area $\sim 2.5 \mathrm{Ma}$ ).

The most detailed gravity map (Carle, 1988) indicates an abrupt contact between caldera fill and a steep basement wall at the west side of the caldera (which there trends northsouth). This main gravity-defined wall passes $2.8 \mathrm{~km}$ west of well 44-16, and a lesser fault block apparently extends $\sim 1 \mathrm{~km}$ farther west, nearly to the base of the exposed topographic wall (fig. 4; fig. 10 of Carle, 1988). A nearby refraction profile (fig. 12d of Hill and others, 1985) shows inboard-thickening caldera-fill units extending from near the topographic wall to a thickness of $\sim 1.4 \mathrm{~km}$ near well $44-16$, which is in accord with the gravity model and close to the $1.6-\mathrm{km}$ thickness of fill actually penetrated in 44-16 (fig. 3).

The steepest gravity gradient is $\sim 1.8 \mathrm{~km}$ west of the Inyo Craters (site of well Inyo-4; fig. 1) and $\sim 2 \mathrm{~km}$ east of the present-day (erosionally retreating) topographic wall. If the steep gravity gradient represents the main outer limit of a complexly nested ring-fault zone, deeply buried by early postcaldera rhyolite and younger basalts, then the zone could include outer faults that influenced the eruptive site of 115-ka Deer Mountain rhyolite (unit rdm, fig. 1), a median fault that governed the 274-m vertical offset of the base of the early rhyolite between wells 44-16 and Inyo-4 (fig. 3), and faults still farther inboard that influenced vent sites for the other west-moat rhyolites (fig. 1) and for the Lookout Mountain edifice (fig. 3 of Hildreth, 2004). Such a nested pattern need not conflict with more complex block faulting, as advocated by Suemnicht and Varga (1988), including potential relay ramps associated with the precaldera left stepover in the rangefront fault system.

We think, however, that a different explanation is required to account for the apparent absence of Bishop Tuff beneath thick early postcaldera rhyolite flows in wells Inyo- 4 and OIP-1 and to account for the supposed 930-m difference in basement elevation between well 44-16 on the one hand, and wells Inyo-4 and OIP-1 on the other. All three wells first penetrated stacks of mafic lava flows $240-370 \mathrm{~m}$ thick $\left({ }^{40} \mathrm{Ar} /{ }^{39} \mathrm{Ar}\right.$ dated at 230-66 ka; Hildreth and others, 2014). Beneath a few tens of meters of fluvial sand and gravel, the wells then passed through several hundred meters of early rhyolite (750-640 ka), which includes a coulee that is $\sim 170 \mathrm{~m}$ thick in Inyo- 4 and $\sim 250 \mathrm{~m}$ thick in 44-16 (Eichelberger and others, 1988). Beneath the coulee, the stratigraphic records diverge (fig. 3). In Inyo-4, the coulee is underlain successively by $\sim 115 \mathrm{~m}$ of early rhyolite pyroclastics and $\sim 63 \mathrm{~m}$ of diamict previously interpreted as glacial till, which rests at a depth of $779 \mathrm{~m}$ on basement rocks dominated by brecciated quartzite (fig. 3 ). In $44-16$, the coulee is underlain successively by $250 \mathrm{~m}$ of nonwelded early rhyolite tuff, $253 \mathrm{~m}$ of welded Bishop Tuff, $\sim 60 \mathrm{~m}$ of Sherwin Till (fig. 6 of Eichelberger and others, 1988), and $>400 \mathrm{~m}$ of Pliocene volcanic rocks, which, at a depth of 1,634 $\mathrm{m}(816 \mathrm{~m}$ asl), rest on metasedimentary basement rocks (fig. 3). The surface elevation of Inyo-4 is $75 \mathrm{~m}$ higher than that of 44-16, so the presumed basement in Inyo-4 is $930 \mathrm{~m}$ shallower than basement in 44-16, which is sited only $1 \mathrm{~km}$ east-southeast. In well OIP-1, the presumed basement in which drilling terminated was entered at an elevation similar to that in Inyo-4 (1,746 m asl), $920 \mathrm{~m}$ shallower than in well 44-16 (figs. 13, 14 of Hildreth and others, 2017).

The contrasting sections (fig. 3) were cited as evidence for a buried fault scarp with $\sim 900 \mathrm{~m}$ of down-to-the-east basement displacement somewhere between wells 44-16 and Inyo-4 (and OIP-1) (Suemnicht, 1987; Eichelberger and others, 1988; Suemnicht and Varga, 1988; Bailey, 1989; Hildreth, 2004). Problems with that interpretation include the following.

(1) How did an early rhyolite coulee (170-250 m thick) surmount a major fault scarp between the wells but show only a modest change in thickness? Even if Bishop Tuff and precoulee early rhyolite tuff had banked high against the scarp, the base of the coulee (fig. 3 ) is still $\sim 150 \mathrm{~m}$ lower in elevation in 44-16 than in Inyo-4 (Eichelberger and others, 1988). Why did the flow not pond against the scarp if all or part of the scarp relief had originated during caldera collapse? An alternative would be that there has been $\sim 150 \mathrm{~m}$ of post-early rhyolite 


\section{SE 2,525 $\mathrm{m}$ asl}

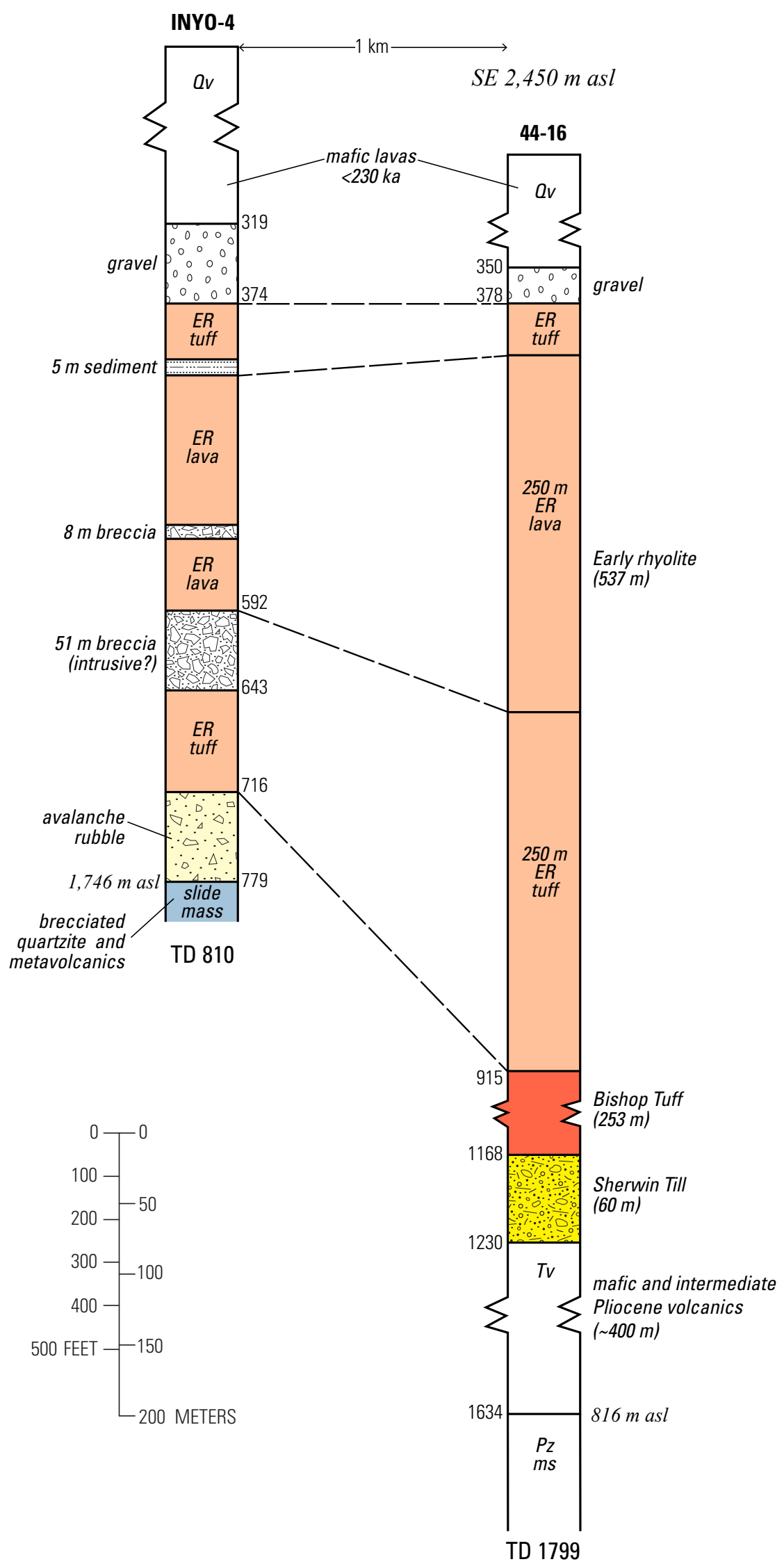

Figure 3. Comparative drillhole stratigraphy of Inyo-4 and 44-16, spudded $\sim 1 \mathrm{~km}$ apart in the west moat of Long Valley Caldera, adapted from Suemnicht (1987) and Eichelberger and others (1988). Vertical depths in meters below surface, recalculated from inclined depths in Inyo-4. Columns in diagram are positioned so that tops of early rhyolite (ER; 750-640 ka) are adjacent. SE, surface elevation of drill sites in meters above sea level ( $m$ asl). TD, total depth of drillholes. Early rhyolite (orange) is less than two thirds as thick in Inyo-4 as in 44-16. Bishop Tuff (red) is $253 \mathrm{~m}$ thick in 44-16 but was not penetrated in Inyo-4. Pliocene volcanic rocks, $\sim 400 \mathrm{~m}$ thick in 44-16, where downfaulted $>1.5 \mathrm{~km}$ vertically inside the caldera, are similar in thickness where still exposed on the present-day caldera rim $\sim 4 \mathrm{~km}$ west (fig. 4). Beneath the early rhyolite in Inyo-4, a 63-m-thick diamict was originally called glacial till but is here reinterpreted as avalanche rubble from the west wall, consisting of precaldera volcanic, granitic, and metamorphic rocks with many angular fragments of each. Inyo-4 bottomed in brecciated quartzite intruded by subordinate chloritized andesite laced with sulfide-carbonate-epidote fracture fillings; all of these lithologies are exposed on the caldera's west wall. Multilithologic breccias within the early rhyolite contain basement and Pliocene basaltic clasts and were therefore interpreted as intrusive by Eichelberger and others (1988) but might, alternatively, be deposits of renewed avalanches from the steep caldera wall up to tens of thousands of years after caldera collapse. $0 v$, Pleistocene lavas and scoria (230-66 ka), mostly basaltic. Tv, Pliocene volcanic rocks. $\mathrm{Pz} \mathrm{ms}$, Paleozoic metasedimentary rocks, downfaulted intracaldera equivalents of those cropping out on west wall (fig. 4). 
down-to-the-east displacement of the coulee on the fault system that reaches the surface near South Inyo Crater (fig. 15 of Hildreth and Fierstein, 2017), where observed surface displacement is no more than $14 \mathrm{~m}$ (Hildreth and Fierstein, 2016a).

(2) How could Bishop Tuff ash flows not have surmounted the scarp and blanketed the moat farther west when such ash flows concurrently poured over the nearby crest of the San Joaquin Ridge, $1.5 \mathrm{~km}$ higher in elevation, and flowed on for tens of kilometers down the Middle Fork San Joaquin River (fig. 4), depositing welded tuff thicker than $200 \mathrm{~m}$ along the canyon floor?

(3) Pliocene basalts and dacites are $\sim 405 \mathrm{~m}$ thick in well $44-16$ and are still $\sim 400 \mathrm{~m}$ thick where they have long been exposed on the caldera rim $4 \mathrm{~km}$ to the west, but they are missing from the Inyo-4 section in between. The base of the Pliocene volcanic section is $1.9 \mathrm{~km}$ lower in well 44-16 than on the caldera wall. The down-to-the-east displacement can be partitioned between caldera subsidence and precaldera rangefront faulting, but complete erosion of so thick a stack of Pliocene lavas from the west-moat floor beneath well Inyo-4 is implausible.

(4) Early rhyolite tuff rests directly on Bishop Tuff in well $44-16$ but in well Inyo-4 it overlies a 63 -m-thick clastic deposit previously interpreted as glacial till (Eichelberger and others, 1988, p. 13,211). Elsewhere in Long Valley Caldera, numerous radioisotopic ages show that early rhyolite erupted in early postcaldera time (750-640 ka; Hildreth and others, 2017). If the Bishop Tuff had been deposited in the west moat beneath the site of Inyo-4, as seems unavoidable, how could it have been completely and rapidly eroded away before emplacement of the early postcaldera rhyolite tuff (which is nonwelded and was not eroded)? Marine Isotope Stage (MIS) 18 ( 712 to $676 \mathrm{ka}$ ), which is not known to have been an especially long or intense cold interval (Lisiecki and Raymo, 2005), took place during deposition of the early rhyolite. Because Inyo- 4 is only $4 \mathrm{~km}$ east of several small cirques on the caldera wall, the diamict beneath the early rhyolite tuff could conceivably have been deposited by cirque glaciers during MIS 18, but such local cirque advances are unlikely to have stripped hundreds of meters of welded Bishop Tuff from the west moat. No Bishop Tuff clasts were reported in the diamict (Eichelberger and others, 1988). A compelling alternative is that the diamict is not glacial.

(5) The supposed basement rocks in which the Inyo-4 well bottomed were reported to consist dominantly of brecciated quartzite, which is cut by altered "porphyritic andesitic hypabyssal intrusives" (Eichelberger and others, 1988). Both rock types crop out on the caldera wall $\sim 3.5 \mathrm{~km}$ west of Inyo- 4 (fig. 4), but neither is brecciated there. Nor are the metasedimentary basement rocks near the bottom of well 44-16 reported to be brecciated (Suemnicht, 1987).

(6) In the caldera's south moat, three wells passed through avalanche masses at or near the top of the Bishop

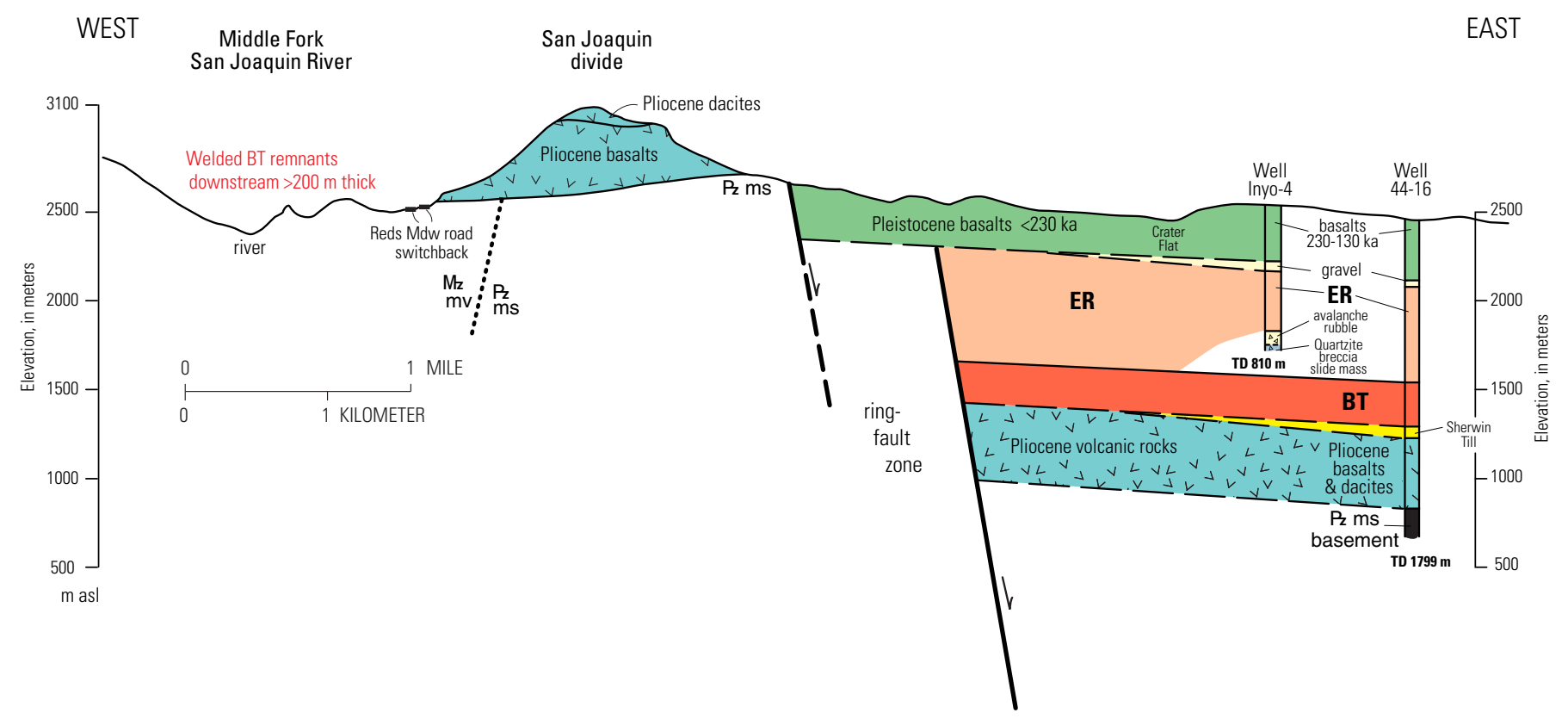

Figure 4. Generalized west-east interpretive section across western margin of Long Valley Caldera. Vertical exaggeration $x$ 1.2. Double ring fault is inferred from stepwise interpretation of gravity profile (fig. 10 of Carle, 1988). Wells Inyo-4 and 44-16 are depicted in more detail in figure 3. TD, total depth; $\mathrm{m}$ asl, meters above sea level. Pliocene volcanic section, $\sim 400 \mathrm{~m}$ thick on the San Joaquin divide and in 44-16, is likely to extend continuously to the ring-fault zone, as is the syncollapse Bishop Tuff (BT) and the postcaldera early rhyolite (ER). During the caldera-forming eruption, Bishop Tuff ash flows crossed the high divide into the Middle Fork San Joaquin River, flowed downstream for tens of kilometers, and left >200 $\mathrm{m}$ of welded tuff on the canyon floor. Pz ms, Paleozoic metasedimentary rocks; Mz mv, Mesozoic metavolcanic rocks. 
Tuff (figs. 1, 2; Suemnicht and others, 2006). The brecciated sheets, which are 43-117 m thick, consist of metasedimentary and granitic rocks from the caldera's south wall, clearly spalled from oversteepened scarps created by ring-fault subsidence during eruption of the Bishop Tuff. In all three wells (M-1, 38-32, and BC 12-31; fig. 1), the avalanche deposit is directly or closely overlain by the base of the early postcaldera rhyolite (fig. 2), again suggesting that little time had elapsed between the caldera-forming eruption of the Bishop Tuff and the onset of early rhyolite eruptions. Similar avalanching of the caldera's west wall seems an appropriate model for the emplacement of the brecciated quartzite formerly interpreted as basement in wells Inyo-4 and OIP-1. Eichelberger and others (1988) recognized the possibility that the brecciated quartzite might be a slide mass rather than basement, but logistical problems dissuaded them from drilling deeper. The 63-m-diamict, previously interpreted as till, that rests on the brecciated quartzite is likely to be an additional sheet of avalanche debris (fig. 3). It was described as containing striated, angular to subrounded blocks as big as $2 \mathrm{~m}$ of Pliocene volcanic rocks, granitoids, and metamorphic rocks in an unconsolidated fines-rich matrix. These are the main rocks that crop out on the caldera wall 3-4 km west of the drill site.

(7) Temperature profiles for wells Inyo-4 and 44-16 were very similar from the surface to depths of $\sim 600 \mathrm{~m}$. The maximum temperature in Inyo- $4\left(80^{\circ} \mathrm{C}\right)$ was recorded at a depth of $490 \mathrm{~m}$, within the early rhyolite coulee, beneath which temperature declined to $\sim 65^{\circ} \mathrm{C}$ in the quartzite breccia at the bottom of the hole. In well 44-16, temperature also increased regularly to $\sim 80{ }^{\circ} \mathrm{C}$ at a depth of $\sim 500 \mathrm{~m}$, likewise in the early rhyolite coulee, then underwent a reversal to $\sim 65^{\circ} \mathrm{C}$ before climbing regularly to a maximum of $214^{\circ} \mathrm{C}$ in the Bishop Tuff at depths of 900-1,100 m, beneath which temperature again declined in the Pliocene volcanic section. Sorey and others (1991) cited the similarity of thermal profiles to depths of at least $600 \mathrm{~m}$ as evidence for hydrologic connection between the sites of the two wells. If the quartzite breccia is an avalanche mass rather than basement, then it would be a reasonable expectation to find welded Bishop Tuff and an increasing thermal profile beneath the breccia. If several subparallel ring faults constitute the caldera's western structural margin, as suggested above, then relay ramps between them may provide the permeable pathways for present-day ascent of Long Valley's high-temperature geothermal fluids, long known to originate in the west moat (Suemnicht, 1987; Sorey and others, 1991).

As well as increasing thermal profiles beneath the slide mass in Inyo-4 (and OIP-1), we expect that deeper drilling farther west in the moat would encounter hundreds of meters of Bishop Tuff and Pliocene volcanic rocks before entering truly intact basement rocks.

\section{Summary}

The deeply subsided structural caldera underlies only about half the area of the Long Valley topographic-hydrographic depression. A concealed zone of multiply nested ring faults that steps the roof plate downward is $2-4 \mathrm{~km}$ wide and underlies an additional third of the caldera floor. Some faults in the zone may be vertical, but most are thought to dip steeply inward. Several postcaldera rhyolites, dacites, and mafic lavas erupted from conduits that penetrated the ring-fault zone. The only postcaldera eruptions inboard of the ring-fault zone were rhyolitic (750-330 ka; Bailey, 1989; Hildreth and others, 2017). Beneath the west moat, the Bishop Tuff and the thick subjacent Pliocene volcanic section, both concealed by a syncaldera landslide mass, are inferred to extend much farther west than previously recognized.

\section{Acknowledgments}

Judy Fierstein, Mae Marcaida, and Gene Suemnicht made contributions important to production of this note. David John and David Boden provided thoughtful reviews that improved the manuscript.

\section{References Cited}

Bailey, R.A., 1989, Geologic map of Long Valley caldera, Mono-Inyo Craters volcanic chain, and vicinity, eastern California: U.S. Geological Survey Map I-1933, pamphlet 11 p., 2 sheets, scale 1:62,500.

Carle, S.F., 1988, Three-dimensional gravity modeling of the geologic structure of Long Valley caldera: Journal of Geophysical Research, v. 93, p. 13237-13250.

Eichelberger, J.C., Vogel, T.A., Younker, L.W., Miller, C.D., Heiken, G.H., and Wohletz, K.H., 1988, Structure and stratigraphy beneath a young phreatic vent-South Inyo Crater, Long Valley Caldera, California: Journal of Geophysical Research, v. 93, p. 13208-13,220.

Greene, D.C., and Stevens, C.H., 2002, Geologic map of Paleozoic rocks in the Mount Morrison pendant, eastern Sierra Nevada, California: California Division of Mines and Geology Map Sheet 53; scale 1:24,000.

Hildreth, W., 2004, Volcanological perspectives on Long Valley, Mammoth Mountain, and Mono Craters - several contiguous but discrete systems: Journal of Volcanology and Geothermal Research, v. 136, p. 169-198. 
Hildreth, W., and Fierstein, J., 2016a, Eruptive history of Mammoth Mountain and its mafic periphery: U.S. Geological Survey Professional Paper 1812, 128 p., 2 plates, scale 1:24,000.

Hildreth, W., and Fierstein, J., 2016b, Long Valley Caldera lake and reincision of Owens River Gorge: U.S. Geological Survey Scientific Investigations Report 2016-5120, 63 p.

Hildreth, W., Fierstein, J., and Calvert, A., 2017, Early postcaldera rhyolite and structural resurgence at Long Valley caldera, California: Journal of Volcanology and Geothermal Research, v. 335, p. 1-34.

Hildreth, W., Fierstein, J., Champion, D., and Calvert, A., 2014, Mammoth Mountain and its mafic periphery-A late Quaternary volcanic field in eastern California: Geosphere, v. 10 , p. $1315-1365$.

Hill, D.P., 1976, Structure of Long Valley caldera, California, from a seismic refraction experiment: Journal of Geophysical Research, v. 81, p. 745-753.

Hill, D.P., Kissling, E., Luetgert, J.H., and Kradolfer, U., 1985, Constraints on the upper crustal structure of the Long Valley-Mono Craters volcanic complex, eastern California, from seismic refraction measurements: Journal of Geophysical Research, v. 90, p. 11135-11150.

Kane, M.F., Mabey, D.R., and Brace, R.-L., 1976, A gravity and magnetic investigation of the Long Valley Caldera, Mono County, California: Journal of Geophysical Research, v. 81, p. $754-762$.

Lipman, P.W., 1997, Subsidence of ash-flow calderas: Relation to caldera size and magma chamber geometry: Bulletin of Volcanology, v. 59, p. 198-218.

Lisiecki, L.E., and Raymo, M.E., 2005, A Pliocene-Pleistocene stack of 57 globally distributed $\delta^{18} \mathrm{O}$ records: Paleoceanography, v. 20, PA 1003, doi:10.1029/2004PA001071.

Metz, J.M., and Bailey, R.A., 1993, Geologic map of Glass Mountain, Mono County, California: U.S. Geological Survey Map I-1995, scale 1:24,000.

Prejean, S., Ellsworth, W.L., Zoback, M., and Waldhouser, F., 2002, Fault structure and kinematics of the Long Valley caldera region, $\mathrm{CA}$, revealed by high-accuracy earthquake hypocenters and focal mechanism stress inversions: Journal of Geophysical Research, v. 107, B12, ESE 9, p. 1-19.

Sorey, M.L., Suemnicht, G.A., Sturchio, N.C., and Nordquist, G.A., 1991, New evidence on the hydrothermal system in Long Valley caldera, California, from wells, fluid sampling, electrical geophysics, and age determinations of hot-spring deposits: Journal of Volcanology and Geothermal Research, v. 48 , p. $229-263$.
Suemnicht, G.A., 1987, Results of deep drilling in the western moat of Long Valley, California: Eos, v. 68, no. 40, p. 785, 798.

Suemnicht, G.A., Sorey, M.L., Moore, J.N., and Sullivan, R., 2006, The shallow hydrothermal system of Long Valley caldera, California: Geothermal Resources Council Transactions, v. 30, p. 465-469.

Suemnicht, G.A., and Varga, R.J., 1988, Basement structure and implications for hydrothermal circulation patterns in the western moat of Long Valley caldera, California: Journal of Geophysical Research, v. 93, B11, p. 13191-13207. 


\section{Overview of the Long Valley Hydrothermal System After Decades of Study}

By William C. Evans 


\title{
Overview of the Long Valley Hydrothermal System After Decades of Study
}

\author{
By William C. Evans
}

\section{Abstract}

The hydrothermal system in the Long Valley Caldera represents a classic example of lateral outflow, where a near-horizontal aquifer conveys hot water to steam vents and thermal springs 5-20 kilometers downgradient from the deep geothermal reservoir. This reservoir, located beneath the caldera's west moat, supplies 370 kilograms per second $(\mathrm{kg} / \mathrm{s})$ of water at $220^{\circ} \mathrm{C}$ to the eastward flowing plume. Within the lateral aquifer, the thermal fluid is progressively diluted, cooled, and chemically altered through reactions with the host rocks, but water-rock equilibration is not achieved due to the high fluid velocity, estimated at $\sim 400$ meters per day from isobutane tracer results. Mixing relations among $\mathrm{B}, \mathrm{Cl}, \delta \mathrm{D}$, and $\delta^{18} \mathrm{O}$ are consistent with a scenario in which (1) thermal wells and springs on and around the resurgent dome tap water from the deep, west moat reservoir, variably diluted in the lateral outflow aquifer; (2) the diluting water is predominantly old groundwater recharged in the eastern part of the caldera;

(3) other thermal or non-thermal waters are not present in significant amounts; (4) the $\mathrm{B}$ and $\mathrm{Cl}$ predominantly derive from metasedimentary host rocks of the deep reservoir, with some possible magmatic input.

Isotopes of carbon and helium show magmatic signatures. Both the heat transport (350 megawatts) and the total $\mathrm{CO}_{2}$ output $\left(\sim 3.3 \times 10^{10}\right.$ grams per year $)$ of the hydrothermal system could be supplied by cooling and degassing of basaltic magma at an intrusion rate of $\sim 0.0025 \mathrm{~km}^{3} / \mathrm{yr}$. A potent magmatic heat source is required to sustain the hydrothermal system over its proposed 40,000-year existence.

Geothermal wells produce $\sim 850 \mathrm{~kg} / \mathrm{s}$ of $160-180^{\circ} \mathrm{C}$ water from the lateral aquifer and feed a binary cycle power plant with an installed capacity of 40 megawatts electrical (MWe). The cooled water is injected below the production depth to minimize breakthrough, but reduced pressure support and aquifer cooling have resulted in local subsidence and expansion of hot ground into surrounding forest. Hydrologic effects of development are monitored, and the monitoring protocol is being updated in response to proposed expansion of the production wellfield.

\section{Acknowledgements}

Comments on the manuscript from Deb Bergfeld, Dave Boden, Chris Farrar, Wes Hildreth, Jim Howle, Shaul Hurwitz, Mike Sorey, and Gene Suemnicht are greatly appreciated. Jim Howle kindly contributed the updated thermal water discharge record from Hot Creek gorge. Various staff members from the Ormat-owned geothermal plant and the Mammoth Community Water District are thanked for their aid in sampling efforts and in providing access to useful hydrologic information over many years.

\section{Introduction}

For the past 50 years, the hydrothermal system in Long Valley Caldera has been the focus of studies having many different motivations. Interest in geothermal power production fueled early investigations of the physical and chemical characteristics of the hydrothermal reservoir; worrisome uplift of the caldera's resurgent dome in the 1980s led to studies of the potential role of hydrothermal fluids in deformation. Hydrothermal alteration has produced economic mineral deposits in the caldera; selected hot springs are used as bathing and recreation sites; thermal springs support a fish hatchery; and, ultimately, the hydrothermal discharge is a significant source of $\mathrm{As}, \mathrm{B}, \mathrm{Cl}$ and other dissolved species into surface waters that serve multiple downstream users. Research on all of these individual topics has led to a greater understanding of the hydrothermal system as a whole.

The state of knowledge about the hydrothermal system has been periodically reviewed in special issues or sections of journals focused on Long Valley (for example, Muffler and Williams, 1976; Blackwell, 1985; Sorey, 1985; Sorey and others, 1991, 2003), and these collections offer an informative and evolving understanding of the system. Some features of the hydrothermal system are now well constrained, such as the recharge area, the source reservoir location and temperature, and the total outflow of hot water. On the other hand, some questions that arose in the early studies are still 
unanswered with certainty, such as exactly what and where is the heat source; what is the source of the solutes; how does mixing with non-thermal groundwater occur; and what are the possible effects of geothermal power production? Both the understood and the uncertain aspects of the hydrothermal system will be discussed in this overview.

Long Valley Caldera comprises a 17- by $32-\mathrm{km}$ ovalshaped topographic depression, a ring-fault zone well inboard of the present topographic boundary, and a resurgent dome that forms a central highland (Bailey, 1989). The caldera floor around the resurgent dome is referred to as a moat, which, for discussion, is divided into west, east, and south sectors (fig. 1). Surface manifestations of the geothermal system, hot springs and pools, are mostly located in the south and east moats.
Chemical similarities among the hot springs pointed to a common deep reservoir for all of the springs (Mariner and Willey, 1976), but reservoir location was not initially obvious. Early geothermal exploration wells (M-1 at Casa Diablo, 66-29 in the east moat) tended to concentrate around the hot springs. Water temperatures up to $175^{\circ} \mathrm{C}$ were encountered, but a deep, source reservoir was not. Wells instead showed temperature reversals with depth, many bottoming out at temperatures near $100{ }^{\circ} \mathrm{C}$ (for example, well M-1, fig. 2). Although hydrothermal outflow plumes, where hot water flows laterally for a considerable distance from the deep, source reservoir to discharge points, were described as early as 1973 (Healy and Hochstein, 1973), the common occurrence of such features was probably not fully appreciated until the 1980s (Goff and

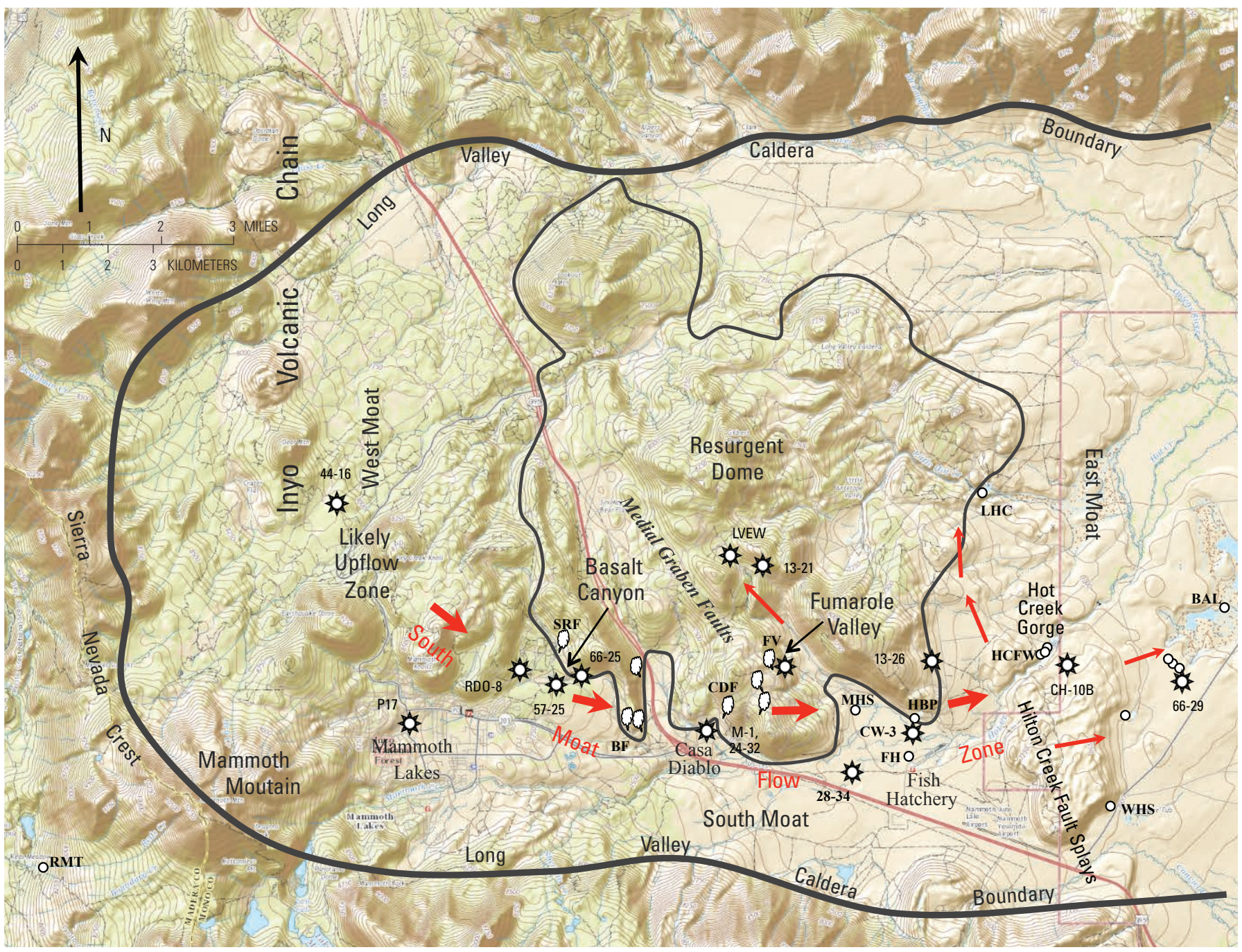

Base map data from The National Map,

U.S. Geological Survey, National Geospatial Program

Figure 1. Map showing the topographic boundary of the 760-ka Long Valley Caldera, resurgent dome, moat, and other major features. The Holocene Inyo volcanic chain cuts north-south across the northwest caldera rim. Red arrows show inferred lateral flow-path of thermal water (through the south moat flow zone) from an upflow area near the Inyo volcanic chain to downgradient wells and hot springs. Selected wells (stars), hot springs (circles), and steam vents (clouds) mentioned in this report are labeled. Abbreviations, from west to east are: RMT, Reds Meadow Tub; SRF, Shady Rest Fumarole; BF, Basalt Fumarole; CDF, Casa Diablo Fumarole; FV, Fumarole Valley; MHS, Meadow Hot Spring; FH, Fish Hatchery spring; HBP, Hot Bubbling Pool; LHC, Little Hot Creek springs; HCFW, Hot Creek far west; WHS, Whitmore Hot Spring; BAL, Big Alkali Lake spring. 
others, 1988; Ingebritsen and Sorey, 1985). Eventually, test wells drilled in the caldera's west moat in the 1980s encountered permeable zones with water temperatures exceeding $200{ }^{\circ} \mathrm{C}$ (fig. $2 A, B$ ).

Chemical geothermometry, mineral equilibration calculations, isotopic ratios, and the temperature profile in a deep test well (44-16) are all consistent with a $\sim 220{ }^{\circ} \mathrm{C}$ source reservoir located in metamorphic basement rocks beneath the west moat, near the eruptive features of the Inyo volcanic chain (fig. 1). Hot water rising from this reservoir encounters permeable zones hundreds of meters below land surface and flows laterally to the southeast through the Casa Diablo geothermal wellfield to discharge points in Hot Creek gorge and isolated thermal springs farther east. Alternative upflow areas that were once thought viable, beneath the resurgent dome or Mammoth Mountain, now seem unlikely, though these areas may host isolated reservoirs that minimally interact with the main flow system.

\section{Volcanic/Tectonic Setting}

The tectonic setting and volcanic history of Long Valley have been discussed by many workers (for example, Bailey and others, 1976; Hill and others, 1985; Suemnicht and Varga, 1988; Hildreth, 2004). Situated in a zone of crustal extension at the western boundary of the Basin and Range Province, the Long Valley region has been volcanically active since about 4.5 Ma. Focusing of mafic intrusions led to eruptions of andesites and dacites beginning about $3.5 \mathrm{Ma}$ in the area that is now the northwestern rim of the Long Valley Caldera. The focus of intrusion shifted eastward to produce the 2.2-0.79-Ma rhyolitic Glass Mountain complex that now forms the northeastern rim of the caldera. The 760-ka eruption that formed the Long Valley Caldera deposited the Bishop Tuff on top of a rapidly subsiding caldera floor. Over the next 100 $\mathrm{ka}$, eruptions within the caldera produced the lavas and pyroclastic deposits of the early postcaldera rhyolite that makes up much of the resurgent dome (fig. 1). Rhyolite continued to erupt sporadically within the caldera until about $100 \mathrm{ka}$ but at considerably smaller volume and with generally greater crystallinity (Hildreth, 2004).

Eruptions of dacitic lavas beginning $100 \mathrm{ka}$ constructed Mammoth Mountain (fig. 1) on the southwest topographic rim of the Long Valley Caldera (Hildreth and others, 2014). This conspicuous edifice is several kilometers outside of the caldera ring fault, and is evidence of another shift in the focus of mafic intrusion. Another new locus of mafic intrusion began in the Mono basin $20 \mathrm{~km}$ north of the caldera about $100 \mathrm{ka}$ (Vasquez and Lidzbarski, 2012), and led to volcanism along the Mono Craters chain, which eventually erupted several $\mathrm{km}^{3}$ of rhyolitic magma, much of it during Holocene time (Bursik and Sieh, 1989). Southern extension of this volcanism formed
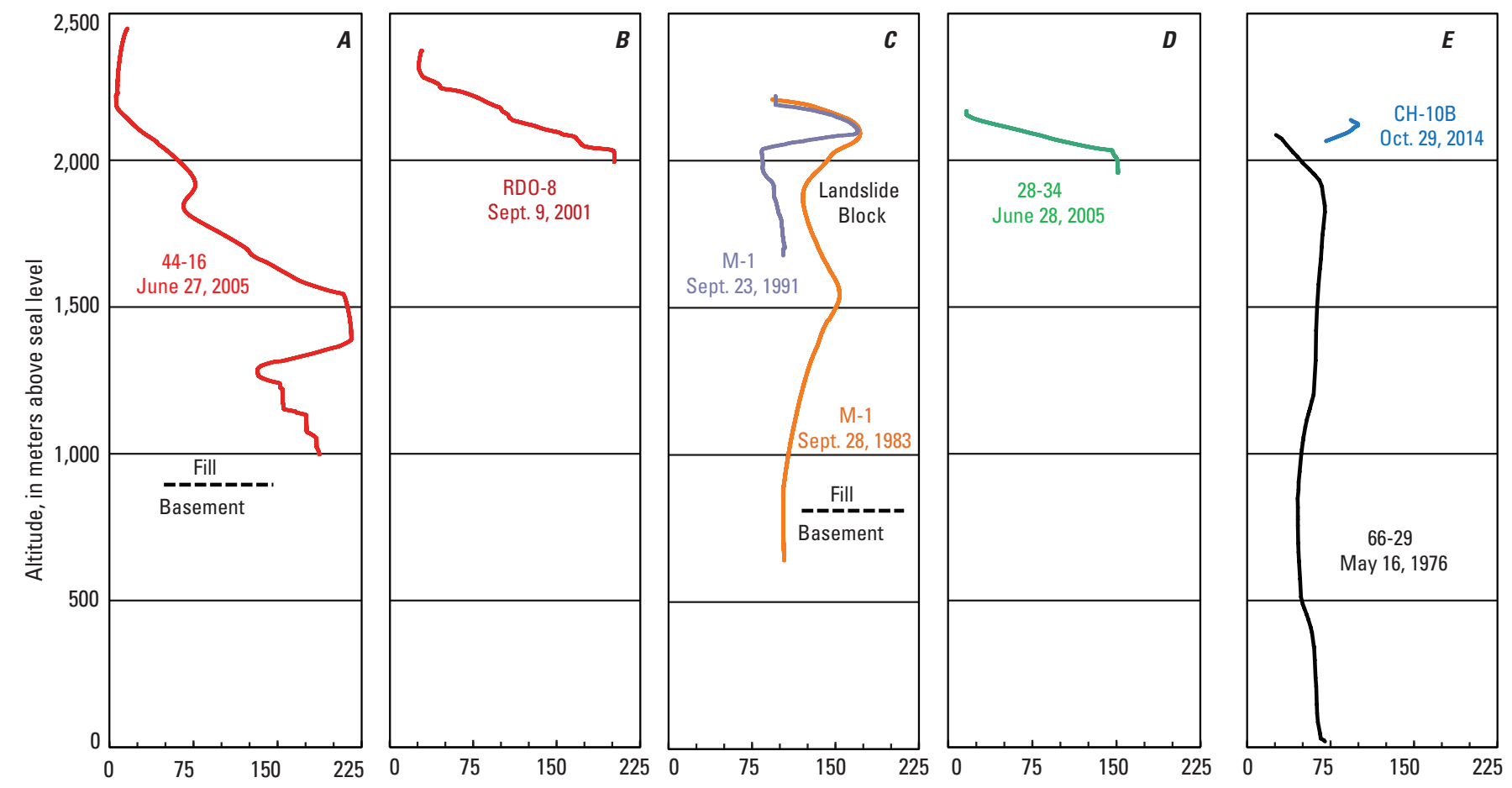

Temperature, in degrees Celsius

Figure 2. Well temperature profiles as a function of altitude above sea level. $A$, well 44-16; $B, \operatorname{RD0}-8 ; C, M-1$ (a deep abandoned well at Casa Diablo geothermal power plant); $D, 28-34 ; E, C H-10 B$ and $66-29$ (a deep abandoned well in the east moat). See figure 1 for well locations. Profiles start at or near the top of casing and, as plotted, show the west-to-east drop in ground surface. Depth to basement is shown where known. All data from the compilation by Farrar and others (2010). 
the Holocene Inyo volcanic chain, and Holocene eruptions of basalt formed the Red Cones $\sim 6 \mathrm{~km}$ south of Mammoth Mountain (Eichelberger and others, 1985; Bursik and others, 2003; Hildreth and others, 2014).

Thus, for several million years, mafic intrusions in the region have been common enough to support several silicic magma chambers at shallow crustal depths where deeply circulating meteoric waters can extract the heat. Other aspects of the volcanic/tectonic setting of significance to the hydrothermal system are as follows. Ongoing deformation and seismicity no doubt create fracture systems that provide connected permeability, favoring the existence of a large and long-lived hydrothermal system. Uneven collapse of the caldera floor during eruption and simultaneous deposition of the Bishop Tuff and subsequent offsets between collapse blocks produced near-vertical pathways to basement in the west moat/ring-fault area, facilitating deep fluid convection (Suemnicht and Varga, 1988). At the same time, fractured zones of high permeability in the caldera fill have lateral continuity within blocks, allowing near-horizontal flow of hot water for many kilometers eastward. The caldera fill is generally $1-2 \mathrm{~km}$ thick, and only a few deep wells penetrate the underlying metamorphic basement.

\section{The Hydrothermal System}

\section{Water Chemistry}

Compilations of temperature and chemistry data for springs and wells in Long Valley Caldera can be found in Mariner and Willey (1976), Shevenell and others (1987), Sorey (1985), Farrar and others (2003), and in appendix A of Brown and others (2013). Well-temperature maxima decrease from $\geq 200{ }^{\circ} \mathrm{C}$ in the west moat to $\sim 100{ }^{\circ} \mathrm{C}$ near Hot Creek gorge (fig. 2), where boiling hot springs discharge. Thermal waters that are not heavily diluted have $\sim 1,500 \mathrm{mg} / \mathrm{L}$ of total dissolved solids, mainly comprising a few hundred $\mathrm{mg} / \mathrm{L}$ each of $\mathrm{Na}, \mathrm{Cl}, \mathrm{HCO}_{3}$, and $\mathrm{SiO}_{2}$, and $\sim 100 \mathrm{mg} / \mathrm{L}$ of $\mathrm{SO}_{4}$. In terms of dissolved species, concentrations of $\mathrm{B}$ and $\mathrm{F}(\geq 10 \mathrm{mg} / \mathrm{L})$ and of As (1-2 $\mathrm{mg} / \mathrm{L}$ ) probably represent the biggest environmental concern.

\section{Recharge Area}

The isotopic composition of precipitation varies greatly across the Long Valley Caldera; for example, typical $\delta \mathrm{D}$ values decrease from -110 per mil on the western rim to about -130 per mil on the eastern rim. White and others (1990) attribute this change to caldera location on the leeward side of the Sierra Nevada crest and to a deep canyon on the windward side of the crest, which exposes the crest more directly to storms from the Pacific Ocean. Waters from the hottest west moat wells have $\delta \mathrm{D}$ values near -110 per mil (fig. 3), confirming that the source of cold water that feeds the deep geothermal reservoir is on the caldera's western rim. Because the western rim is an area of heavy winter snowfall, the hydrothermal reservoir has an abundant supply of cold recharge water.

\section{Reservoir and Fluid Upflow}

The hottest well in the caldera (44-16) penetrated metamorphic basement beneath the west moat, but the highest temperature $\left(214^{\circ} \mathrm{C}\right)$ was encountered in the overlying volcanic fill (fig. $2 A$ ). Nonetheless, evidence from $\mathrm{B} / \mathrm{Cl}$ ratios (Shigeno, 1986) and Sr isotopes (Goff and others, 1991) pointed to a reservoir within basement containing metasedimentary rocks, and it was concluded from the temperature reversal that 44-16

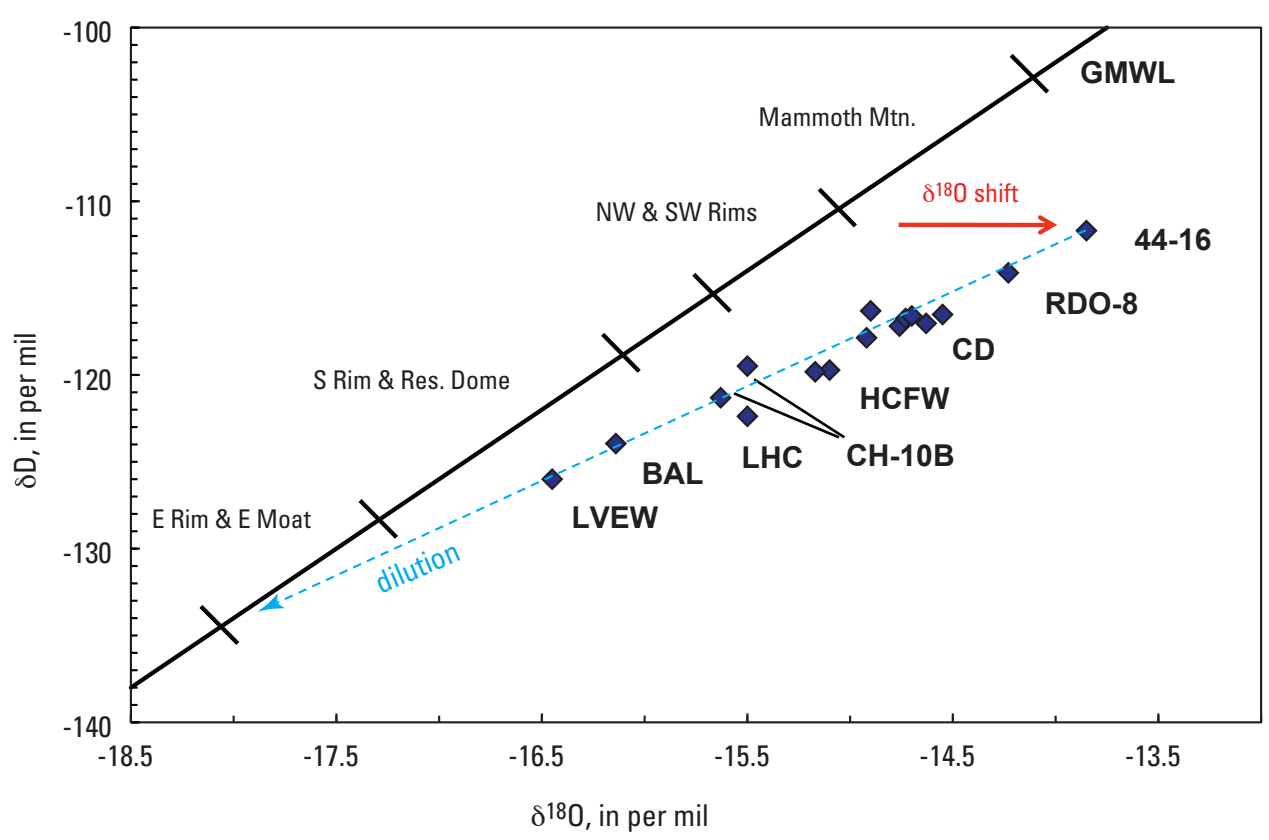

Figure 3. Stable isotope values of Long Valley thermal waters (collected without boiling) compared to the global meteoric water line (GMWL) of Craig (1961) and to the isotopic compositions of cold water in various parts of the caldera, which plot along the global meteoric water line between the tick marks shown (adapted from Sorey and others, 1991). Water from well 44-16 shows an oxygen isotope shift of $\sim 1.5$ per mil from the composition of precipitation on the caldera's western rim; the oxygen isotope shift in other hot waters reflects subsequent dilution of well 44-16 water during eastward flow by isotopically light, non-thermal water. Sites labeled as on figure 1 except that "CD" is data from several wells at Casa Diablo. Data from Brown and others (2013) except LVEW from Farrar and others (2003). 


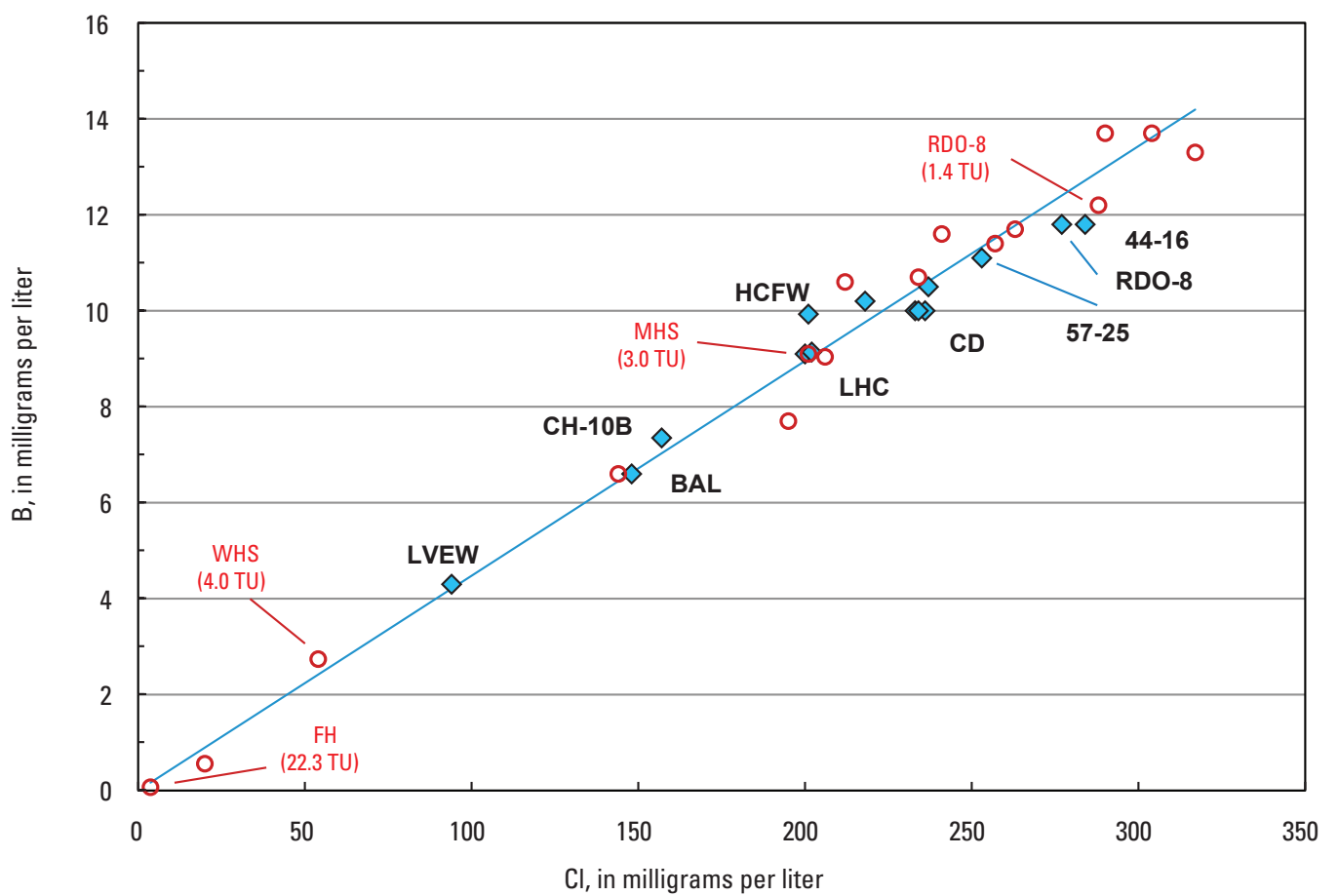

Figure 4. Boron and chloride concentrations at selected sites sampled $\sim 20$ years apart: red circles, early data from Shevenell and others (1987); blue diamonds, recent data from Brown and others (2013) except LVEW from Farrar and others (2003). Tritium concentrations (in tritium units, TU) from Shevenell and others (1987) are shown for the sites with $>1$ TU. Wells RD0-8 and 44-16 indicate a boron concentration of $12 \mathrm{mg} / \mathrm{L}$ for the endmember thermal fluid; higher values in early dataset were from Casa Diablo hot spring samples concentrated by boiling. See figure 1 for site locations and names. was drilled close to, but not directly within, the upflow zone for reservoir fluid (Sorey and others, 1991). Recent threedimensional magnetotelluric imaging reveals a robust conductive body 4-8 km deep beneath the west moat, purportedly the geothermal reservoir, with a connection to the surface near well 44-16 (Peacock and others, 2016). Suemnicht and Varga (1988) proposed that a faulted area of rhyolitic extrusion just south of well 44-16 was the likely zone of thermal water upflow (fig. 1). Although well 44-16 provides the best constraints on the temperature and chemistry of deep reservoir fluid, it is important to note that it does not denote the exact location of upflow.

Sorey and others (1991) considered two other areas where upflow could occur: beneath Mammoth Mountain, or beneath the west side of the resurgent dome. Subsequent studies showed that fumarolic and diffuse gas emissions from Mammoth Mountain contain a distinctive non-atmospheric $\mathrm{N}_{2}$ component, which is not found in geothermal gases within the caldera, pointing to separate thermal sources for the two areas (Sorey and others, 1998). Completion of the 3-km deep Long Valley Exploration Well (LVEW) into basement beneath the resurgent dome found a maximum temperature of only $103^{\circ} \mathrm{C}$ (Farrar and others, 2003). Thus neither of these two areas is a likely zone of upflow from a reservoir in the west moat. Interestingly, the early thermal modeling of Casa Diablo wells had led Blackwell (1985) to propose that the lateral flow of thermal water began 4-6 km to the west, compatible with the upflow location now favored.

\section{Lateral Outflow-The South Moat Flow Zone}

The Bishop Tuff and early postcaldera rhyolite contain permeable zones that allow the hot water to flow eastward beneath the caldera floor (Sorey and others, 1991). Along the flowpath, the ground surface elevation drops enough that water can boil by decompression and discharge at the surface. In the natural, pre-development state, this occurred at Casa Diablo (fig. 1), where neutral-Cl hot springs and a geyser were a tourist attraction in the 1920s. Hot springs and pools issue downgradient for many $\mathrm{km}$ to the east; the main group of hot springs is located inside the Hot Creek gorge. Thermal springs extend farther eastward nearly to the shore of Lake Crowley. For simplicity, this $\sim 20-\mathrm{km}$ long flow system is referred to herein as the "south moat flow zone" even though it begins in the west moat, ends in the east moat, and consists in some places of depth-distributed aquifers.

A few weak steam vents (for example, "SRF" and "BF," fig. 1) occur west of Casa Diablo (Sorey and others, 1993a), and these can be interpreted as locations where the combined pressure of steam and dissolved gas in the south moat flow zone exceeds the confining pressure of overlying groundwater and a permeable flowpath for steam and gas extends upward to the ground surface. Little significance was initially attached to these features, because interest in geothermal development remained focused on hot spring areas such as Casa Diablo. However, gas samples from these steam vents provide an opportunity to study gas geochemistry of the thermal water far 
upgradient from the vigorously boiling, and now commercially disturbed, area at Casa Diablo.

The flow rates and boron concentrations of the various thermal springs were measured and compiled prior to geothermal development (Mariner and Willey, 1976; Sorey, 1985; Shevenell and others, 1987). Boron concentrations were observed to decrease from west to east because the thermal water was increasingly diluted by non-thermal water. As the boron concentration in the deep reservoir became better constrained (at $12 \mathrm{mg} / \mathrm{kg}$ ) by data from the deepest and hottest wells in the west moat (fig. 4), the amount of dilution could be determined, allowing the total flow of reservoir water discharged by the various hot springs to be calculated at $370 \mathrm{~kg} / \mathrm{s}$ (Sorey and others, 1991). This calculation assumes that boron is conservative in solution and that all of the boron is derived from the reservoir; none is leached from the rocks of the south moat flow zone or derived from non-thermal water input. The correlation line with $\mathrm{Cl}$ that extends to the origin (fig. 4) supports this assumption.

In a $\sim 3-\mathrm{km}^{2}$ area around Casa Diablo, the south moat flow zone is split into two depth intervals by a low-permeability landslide block encountered in a few wells (fig. 2C). This unit represents a section of the southern caldera wall that collapsed soon after deposition of the Bishop Tuff and was subsequently covered by flows of the early rhyolite (Suemnicht and others, 2006). The upper flow zone interval, in early rhyolite, is the warmer at $\sim 175^{\circ} \mathrm{C}$, while the lower interval, in Bishop Tuff, is about $25^{\circ} \mathrm{C}$ cooler (see $1983 \mathrm{M}-1$ profile in fig. 2C). Suemnicht and others (2006) credit this landslide block with isolating the early rhyolite aquifer from underlying cooler water, maintaining the aquifer at a temperature useful for geothermal power production.

\section{Geothermometry}

Various chemical geothermometers have been used to constrain reservoir temperature. Mariner and Willey (1976) used silica and cation geothermometers to yield a best estimate of $220^{\circ} \mathrm{C}$, but allowed that higher temperatures were possible. Fournier and others (1979) proposed a maximum reservoir temperature of $282{ }^{\circ} \mathrm{C}$, based on enthalpy-chloride-silica relations and the ${ }^{18} \mathrm{O}$ values of sulfate and water. As more chemical data from newer, hotter wells became available, Sorey and others (1991) calculated a reservoir temperature range of 214- $248{ }^{\circ} \mathrm{C}$ - the lower value based on the measured temperature in well 44-16; the upper value based on the assumption of anhydrite saturation in the reservoir.

The initial samples from well 44-16 were collected using air lift and were slightly contaminated by drilling fluids, heavily degassed, and therefore not ideal for chemical geothermometry (Sorey and others, 1991). Between 2005 and 2007, a suite of pressurized samples was collected from many of the hot wells, including 44-16. These samples, reported in appendix A of Brown and others (2013), allow for determination of down-hole $\mathrm{pH}$ and can be used to calculate mineral saturation states as well as geothermometer temperatures. Figure $5 \mathrm{~A}$ compares temperatures calculated by various geothermometers to the maximum measured downhole temperatures in each well in the form of a west-to-east transect along the south moat flow zone. Mineral saturation indices were also calculated for each well at maximum down-hole temperatures (fig. $5 B$ ) using the geochemical code SOLMINEQ.88 (Kharaka and others, 1988).

At a temperature of $220^{\circ} \mathrm{C}$, water in well $44-16$ is very close to saturation with anhydrite, fluorite, and quartz, as expected for a geothermal reservoir. In fact, the calculated ion activity products for several common minerals are within one $\log$ unit of equilibrium at this temperature, the slight oversaturation in calcite being the only unexpected indicator of disequilibrium (fig. 5B). Most common geothermometers are also consistent with a reservoir temperature of $220^{\circ} \mathrm{C}$ (fig. $5 A$ ), and only the Na-Li geothermometer indicates an appreciably higher value. The water from well 44-16 thus appears to be a good representation of the deep reservoir fluid that feeds into the south moat flow zone.

\section{Physical/Chemical Processes in the South Moat Flow Zone}

The dilution that occurs in the south moat flow zone, clearly seen in decreasing $\mathrm{Cl}$ and $\mathrm{B}$ concentrations (fig. 4), is widely acknowledged, but the water-rock interactions that also occur are less frequently discussed. The importance of these reactions is demonstrated in figure $5 \mathrm{C}$, which shows the concentration changes for several species over a large part of the flowpath. While $\mathrm{Cl}$ concentrations drop 46 percent in a fairly continuous manner, $\mathrm{HCO}_{3}$ and $\mathrm{Na}$ show higher concentrations toward the beginning and end of the flowpath. Potassium follows the $\mathrm{Cl}$ trend but shows a larger overall percentage of decline. Calcium variations show no clear relation to any other solute, and Mg concentrations (not shown) are $<0.02$ millimolar in all these waters.

Evans and others (2013) invoked $\mathrm{CO}_{2}$-driven dissolution of albite to account for increases in $\mathrm{Na}$ and $\mathrm{HCO}_{3}$ in the early part of the flow path. Large-scale loss of $\mathrm{CO}_{2}$, mainly due to surface degassing (Bergfeld and others, 2006), maintains calcite saturation and low $\mathrm{Ca}$ concentrations in solution until east of well 24-32 at Casa Diablo (fig. 5B). Dissolution of previously formed calcite down gradient from Casa Diablo was proposed to account for a significant change in ${ }^{44} \mathrm{Ca}$ values in waters east of that point (Brown and others, 2013). Tempel and others (2011) conducted mass balance modeling of the system between RDO-8 in the west and Casa Diablo in the east. Their results also show dissolution of albite and precipitation of quartz as the dominant processes but differ with respect to calcite behavior. The discrepancy may reflect differences in their assumed in-situ $\mathrm{pH}$ from the $\mathrm{pH}$ values calculated from downhole data (Brown and others, 2013). Regardless, decreasing temperature, and to a minor extent, dilution between wells 44-16 and $\mathrm{CH}-10 \mathrm{~B}$ drive the fluid composition further from 

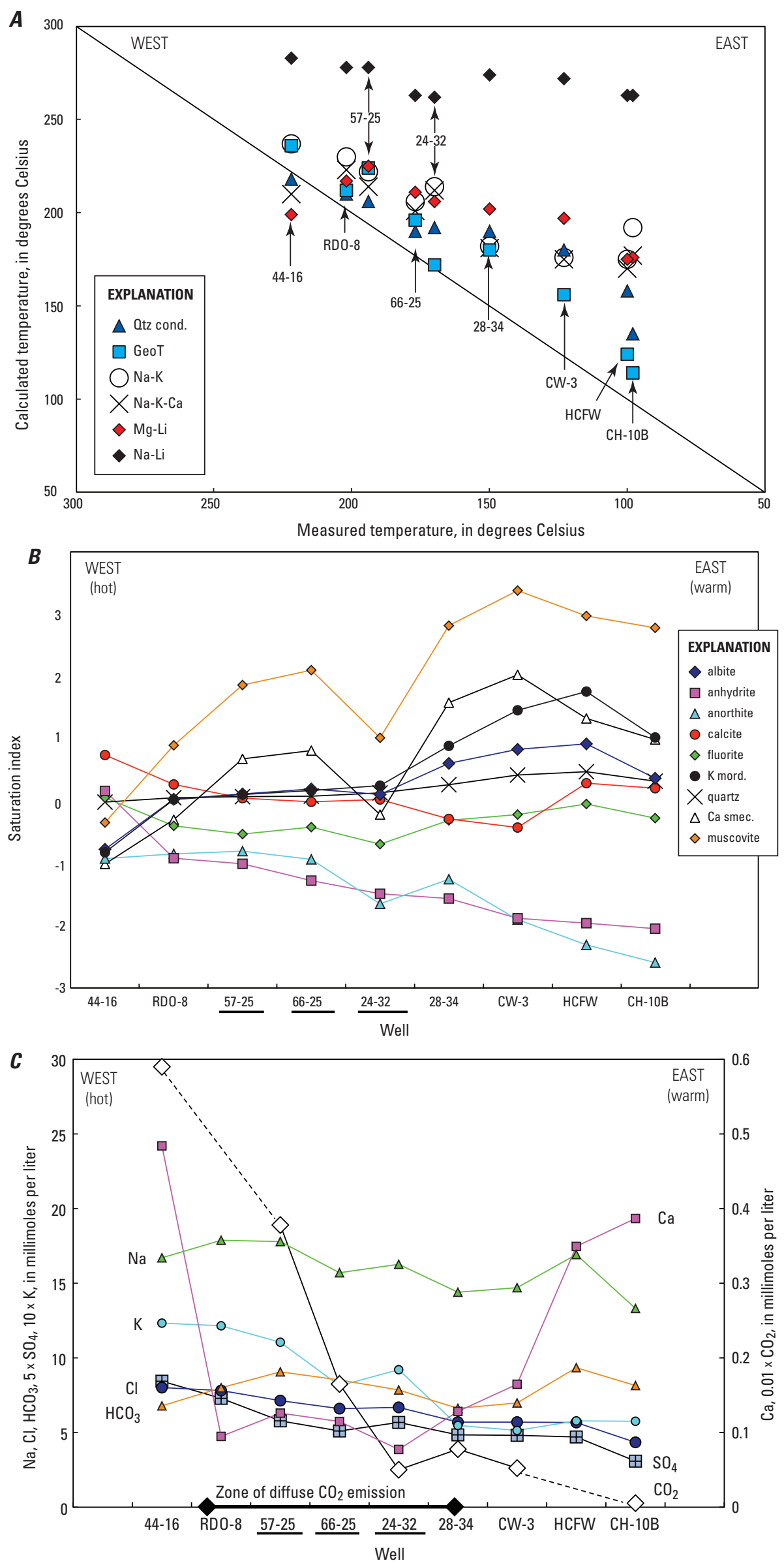

Figure 5. West-to-east transects (not scaled to distance) of chemical properties, modified from Evans and others (2013) based on data in Brown and others (2013). See figure 1 for well locations and names. $A$, Temperatures calculated for various chemical geothermometers plotted against maximum measured downhole temperature (discharge temperature for spring HCFW). Geothermometers selected were quartz conductive, sodium-potassium, sodium-potassium calcium, magnesium-lithium, and sodium-lithium; temperatures were calculated using the equations in SOLMINE0.88 (Kharaka and others, 1988). The GeoT code of Spycher and others (2014) was also used to calculate temperature. Black line denotes perfect agreement between measured and calculated values. $B$, Mineral saturation indices (log of activity product divided by equilibrium constant) for various minerals calculated using SOLMINEO.88 at maximum measured downhole temperatures. Geothermal production wells are underlined. $C$, Plots of concentration of selected chemical species; $\mathrm{CO}_{2}$ values from pressurized samples. Wells associated with a zone of diffuse $\mathrm{CO}_{2}$ emissions are marked on $\mathrm{x}$-axis. Geothermal production wells are underlined. In order to plot all species together, $\mathrm{SO}_{4}$ concentrations are multiplied by $5, \mathrm{~K}$ is multiplied by 10 , and $\mathrm{CO}_{2}$ is multiplied by 0.01 . 
equilibrium with aquifer mineralogy (fig. $5 B$ ). Water-rock interactions occur but are not fast enough to restore equilibrium. Thus, geothermometer temperatures do decline from west to east but not as fast as downhole temperatures (fig. $5 A$ ). The fact that the water-rock reaction rates are too slow to keep pace with the dropping temperature is an indication of high fluid velocity in the south moat flow zone.

\section{Remaining Uncertainties}

\section{Age and Flow Characteristics of the Hydrothermal System}

Stream drainage from Long Valley Caldera flows southward through the Owens River under natural conditions into a series of lakes, where evaporation concentrates the dissolved salts. Smith (1976) recognized that the salt layers at Searles Lake, $250 \mathrm{~km}$ south of Long Valley, preserved a long-term record of thermal water discharge, and proposed that the current hydrothermal system has been active for $30,000-40,000$ years. Calculations of boron leaching rates led Sorey (1985) to further conclude that the system had been active at near-present-day rates for 40,000 years. In contrast, Blackwell (1985) used thermal modeling of well temperature profiles to argue that hot water flow in the shallow lateral aquifer began only 500-700 years ago, reinvigorating a waning hydrothermal system that had cooled to $<120^{\circ} \mathrm{C}$.

$\mathrm{A}^{230} \mathrm{Th} /{ }^{234} \mathrm{U}$ disequilibrium date for sinter near Casa Diablo of $31 \pm 9$ ka (Sorey and others, 1991) eventually supported the 40,000-year age for the present-day hydrothermal system, seemingly disproving the low background temperature conditions assumed by Blackwell (1985). However, the difficulties Blackwell (1985) points out in reconciling the fine-scale complexities in some of the well temperature profiles with steady flow conditions for 40,000 years remain. Martini (2002) notes that high-temperature alteration minerals related to the early phases of the current system can be found in the western caldera, and Suemnicht and others (2006) suggest that the current pattern of outflow to lower elevations may have been caused by subsequent fracturing and fault movements. A scenario in which episodic changes in fluid flow paths occur somewhat frequently over the life of the system, even as total outflow might remain constant, can certainly be envisioned and might reconcile the conflicting ages proposed by Blackwell (1985) and Sorey and others (1991).

\section{Heat Constraints}

The heat output associated with $370 \mathrm{~kg} / \mathrm{s}$ of water at $220{ }^{\circ} \mathrm{C}$ is $\sim 350 \mathrm{MW}$ (slightly lower values in previous studies [for example, Sorey, 1985] were based on different flowrates and temperatures). This is an order of magnitude higher than expected for background conductive heat flow over the area of the caldera floor (Lachenbruch, 1976a; Blackwell, 1985), and many authors have noted the need for a substantial amount of magmatic heat to drive such a system over millennial timescales. Residual melt in the silicic magma chamber that produced the caldera could have supported much of the heat extracted into an earlier, more extensive, and highertemperature hydrothermal system that peaked $\sim 300 \mathrm{ka}$ and persisted to perhaps $130 \mathrm{ka}$ (Lachenbruch and others, 1976a, 1976b; Sorey, 1985; Sorey and others, 1991; McConnell and others, 1997; Suemnicht and others, 2006), but the present-day Long Valley magma chamber is thought to have crystallized and cooled (Hildreth, 2004). Although many geophysical studies have invoked magmatic intrusion deep beneath the resurgent dome as the cause of recent uplift (for example, Langbein, 2003), the low temperature (of $100{ }^{\circ} \mathrm{C}$ ) in the $3-\mathrm{km}$ deep LVEW shows that any such intrusion is an unlikely heat source for a present-day hydrothermal system (Farrar and others, 2003; Fischer and others, 2003).

The heat source for the present-day system is often linked to renewed intrusive activity beneath the Inyo volcanic chain within the west moat. Sorey (1985) calculated that the heat required to sustain the present-day system for 40,000 years equates to crystallization and cooling, from $800{ }^{\circ} \mathrm{C}$ to $300{ }^{\circ} \mathrm{C}$, of $100 \mathrm{~km}^{3}$ of silicic magma $\left(0.0025 \mathrm{~km}^{3} / \mathrm{yr}\right)$. He noted that this volume could be cut in half by assuming basaltic intrusion and cooling from $1,100{ }^{\circ} \mathrm{C}$ to $300{ }^{\circ} \mathrm{C}$. However, compositional and petrographic studies of the most recent Inyo chain eruption $\sim 700$ years ago suggest that basaltic intrusions have reactivated the northwest part of the silicic Long Valley magma chamber (Bailey, 1989; Varga and others, 1990; Reid and others, 1997; Hildreth, 2004). In that case, the basaltic magmas might only cool to $\sim 800{ }^{\circ} \mathrm{C}$, and an intrusion rate of $0.0025 \mathrm{~km}^{3} / \mathrm{yr}$ is still required to supply the heat output (Bergfeld and others, 2015a).

Numerous basalts have erupted in the west moat and around Mammoth Mountain over the past $160 \mathrm{ka}$, and within the past few million years, the rate of basaltic intrusion has been high enough to induce the formation of large silicic magma chambers on fairly short timescales (Hildreth, 2004). Thus, a basaltic intrusion rate of $0.0025 \mathrm{~km}^{3} / \mathrm{yr}$ at the present time seems reasonable. Emplacing $100 \mathrm{~km}^{3}$ of basalt beneath the west moat at shallow enough depths (for example, subjacent to the silicic chamber) to supply the heat for a 40,000 year-old hydrothermal system is geometrically challenging. Evidence suggesting that the hydrothermal system has been active for 40,000 years at its present state is largely based on mass transfers-leaching of boron from source rocks, accumulation of boron in the Searles Lake salts, and so on. Estimates of the hot water discharge, and therefore heat output, are not so well constrained by such data. For example, if boron concentrations in the thermal water were much higher early in the lifespan of the hydrothermal system, due to, for example, more efficient leaching, then export of boron from the caldera at present-day rates would occur at much lower rates of hot-water 
discharge. This scenario would allow the integrated volume of intruded basalt to be substantially less than $100 \mathrm{~km}^{3}$, but some tens of cubic kilometers would likely be required. The recent three-dimensional magnetotelluric imaging that appears to show the hydrothermal reservoir does not clearly delineate a large body of underlying magma (Peacock and others, 2016). The depths, volumes, and precise locations of magmatic intrusions that could serve as a potent heat source are still a major source of uncertainty.

\section{Solute Sources}

While models of water-rock interaction demonstrate release of certain solutes (like sodium) from minerals in the aquifer in the south moat flow zone (Tempel and others, 2011; Evans and others, 2013), uncertainties about the sources of some solutes can be difficult to resolve. For example, White and Peterson (1991) argued that the metasedimentary basement rocks were not capable of sourcing the boron in the hydrothermal fluids. They developed a mass-balance approach to suggest that the boron and chloride discharged by Long Valley thermal fluids over 40,000 years could be derived from leaching rhyolitic rocks of the volcanic fill, though they acknowledge a possible contribution of magmatic boron and chloride as well.

In contrast, Sorey and others (1991) argued that the volume of volcanic fill flushed by the current system was far too small to fit the model of White and Peterson (1991). In addition, the volcanic fill would likely have been depleted in boron and chloride during the earlier ( $\sim 300 \mathrm{ka})$ period of hydrothermal activity. Magmatic and metasedimentary sources remain possible.

Views on the source of carbon in the hydrothermal system range from "predominantly magmatic" (Hilton, 1996) to "more likely" derived from metasedimentary basement rocks (White and others, 1990). The latter authors point out that $\delta^{13} \mathrm{C}$ values in various Paleozoic metasedimentary units that surround Long Valley and are likely to be present in the caldera basement range from 0.0 to -11.9 per mil, encompassing the range of -3 to -7 per mil for $\mathrm{CO}_{2}$ gas in the hydrothermal features. However, some of the variability in carbon isotopes across the caldera no doubt results from fractionation effects such as gas loss during lateral flow and during bubble formation within the spring vents (Brown and others, 2013; Hilton, 1996). Sorey and others (1998) noted that $\delta^{13} \mathrm{C}$ values in $\mathrm{CO}_{2}$ were all near -4 per mil in the steam vents west of Casa Diablo (for example, SRF and BF), features that represent the first instances of gas loss from the reservoir fluid.

Bergfeld and others (2015a) compared these steam vents to similar vents on and $1 \mathrm{~km}$ southeast of Mammoth Mountain and to vents atop the Mono Craters chain $\sim 20-\mathrm{km}$ north of the caldera and found remarkable commonalities in their average gas compositions: $\delta^{13} \mathrm{C}=-4.3 \pm 0.5$ per mil; ${ }^{3} \mathrm{He} /{ }^{4} \mathrm{He}=4.5 \pm 1.4$ times the air ratio $\left(\mathrm{R}_{\mathrm{A}}\right)$; He concentration $=28 \pm 12$ parts per million by volume (ppmv); $\mathrm{CO}_{2}{ }^{\beta} \mathrm{He}=0.84 \pm 0.07 \times 10^{10}$. They noted that carbon derived from a range of basement rocks spread over this large area would be unlikely to have such a small range in $\delta^{13} \mathrm{C}$ values, and propose that the carbon is mostly derived from basaltic intrusions that share a common carbon isotopic value across the region.

The combined sum of $\mathrm{CO}_{2}$ and $\mathrm{HCO}_{3}$ concentrations in well $44-16$ is $0.065 \mathrm{M}$ (fig. $5 C$ ), and the $370 \mathrm{~kg} / \mathrm{s}$ outflow of the hydrothermal fluid represents a $\mathrm{CO}_{2}$ output of $\sim 3.3 \times 10^{10} \mathrm{~g} / \mathrm{yr}$. Complete degassing of $0.0024 \mathrm{~km}^{3} / \mathrm{yr}$ of basalt with an initial $\mathrm{CO}_{2}$ content of 0.5 weight percent would be needed to supply this amount of $\mathrm{CO}_{2}$ (Bergfeld and others, 2015a). This degassing rate is similar to the intrusion rate needed to account for the convective heat output of the hydrothermal system as calculated above, and thus the argument for a mainly magmatic carbon source is reasonable.

\section{Fluid Velocity}

White and Peterson (1991) derived a residence time underground of 1,300 years for the thermal fluid, using their massbalance model described above. Relatively high fluid velocities of $100-200 \mathrm{~m} / \mathrm{yr}$ in the south moat flow zone were estimated from thermal modeling by Blackwell (1985). Together, these values suggest that most of the underground residence time would be spent in the deep reservoir, and that flow through the south moat flow zone (from the upflow zone to Hot Creek) would require about 100 years. Important assumptions made in both models - the rhyolitic source of boron and chloride assumed by White and Peterson (1991), and the recent onset of hydrothermal activity assumed by Blackwell (1985) —were called into question by Sorey and others (1991), and the results should be viewed as qualitative.

A series of inadvertent injections of isobutane into the lower (Bishop Tuff) aquifer at the Casa Diablo geothermal plant began in January 1993, and isobutane was detected within 4 years at the thermal springs in Hot Creek, $8 \mathrm{~km}$ down gradient (fig. 6). Tracer-front velocities in this part of the flow system are thus near $2 \mathrm{~km} / \mathrm{yr}$, and an average fluid velocity (particle velocity) of $\sim 400 \mathrm{~m} / \mathrm{yr}$ was estimated (Evans and others, 2004). High fluid velocities are in agreement with water-rock disequilibrium in the south moat flow zone, as discussed above.

\section{Mixing and Dilution}

The source of the non-thermal water that mixes with the thermal water during its eastward flow through Long Valley Caldera is something of a puzzle. The plot of $\delta \mathrm{D}$ and $\delta^{18} \mathrm{O}$ in figure 3 and plots of those isotopes versus $\mathrm{Cl}$ or B (fig. 7) are all consistent with a single source of non-thermal water having a $\delta \mathrm{D}$ value near -135 per mil and a $\delta^{18} \mathrm{O}$ value near -18 per mil, which are the values at the intersection point of the dilution line with the global meteoric water line (fig. 3). Because such light isotopic values could not be found in non-thermal groundwaters of the western or central caldera, a source in the eastern part of the caldera was proposed and led to the model of a westward 

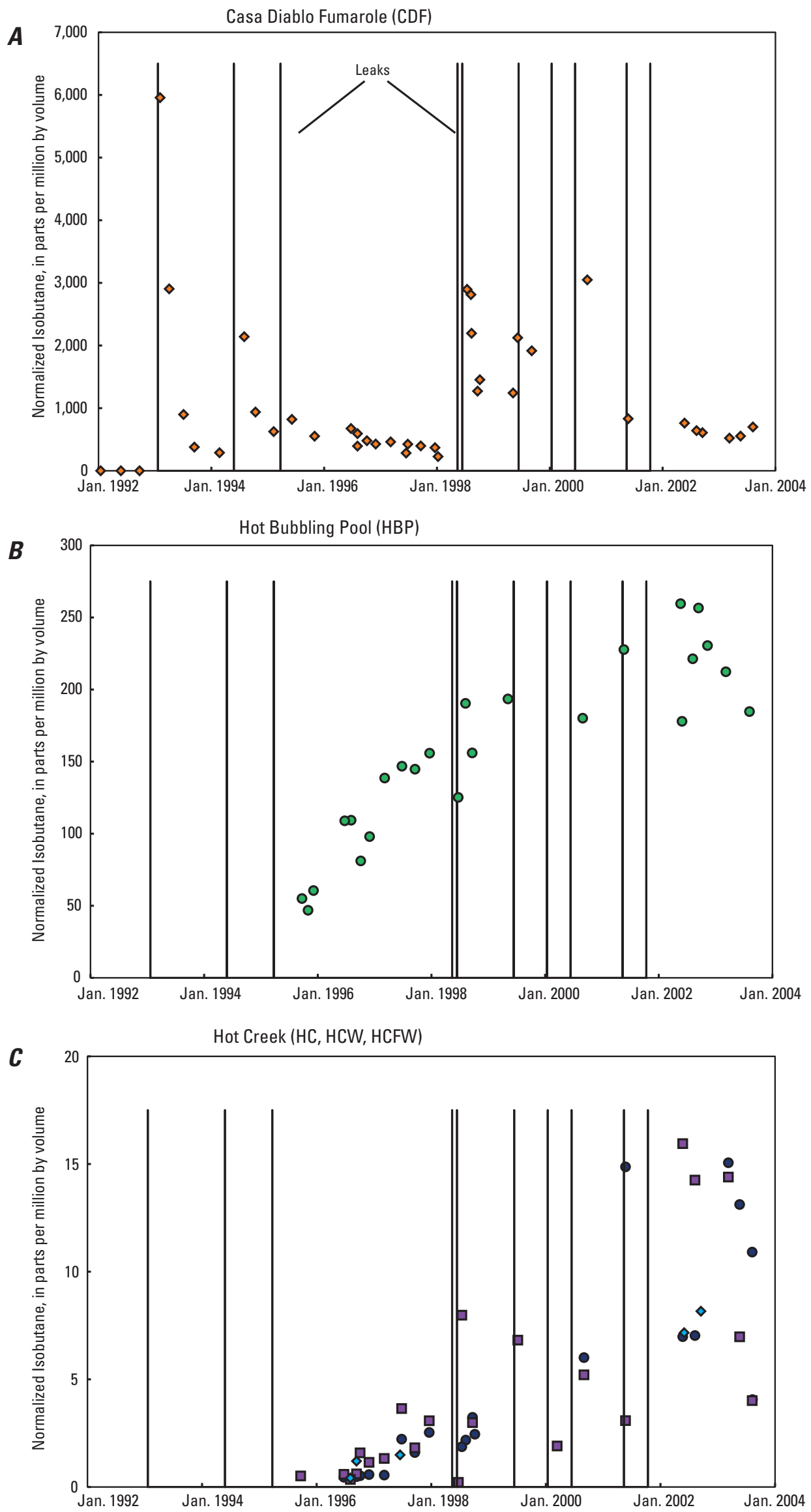

Figure 6. Isobutane concentration, in parts per million by volume (ppmv), between 1992 and 2004 (modified from Evans and others, 2004). All values normalized to an air-free composition to remove the variable effects of air contamination. Vertical lines show dates of known leaks in the heat exchangers at Casa Diablo geothermal plant beginning in January 1993. $A$, Immediate response to leaks observed in steam vent (CDF) at Casa Diablo; $B$, arrival of isobutane after $\sim 2$ years at HBP, 4 km down gradient; $C$, arrival after $\sim 4$ years at Hot Creek gorge, $8 \mathrm{~km}$ down gradient, as measured in three springs in the gorge: $\mathrm{HC}$ (squares); HCW (circles); and HCFW (diamonds). See figure 1 for site locations and names. 

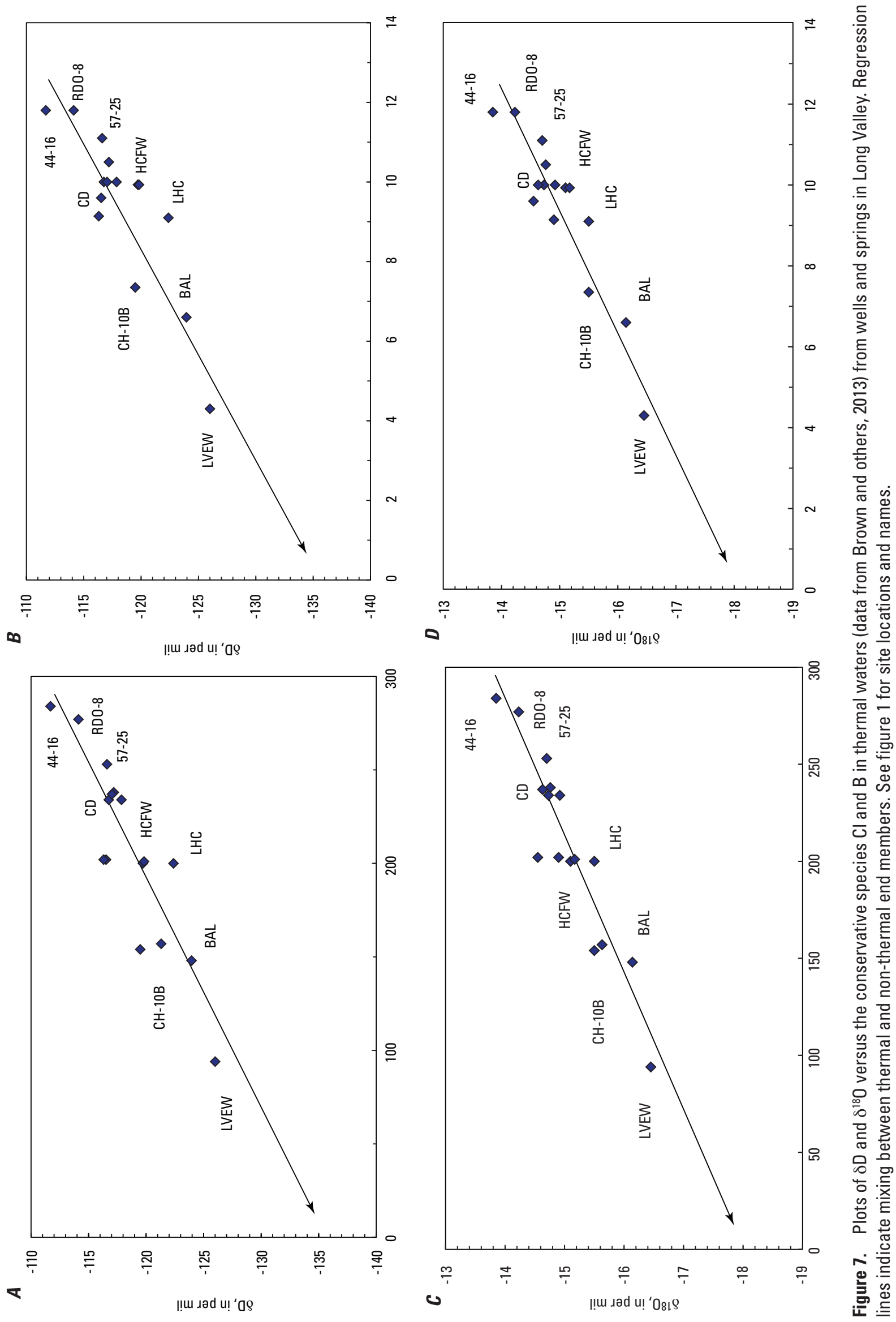


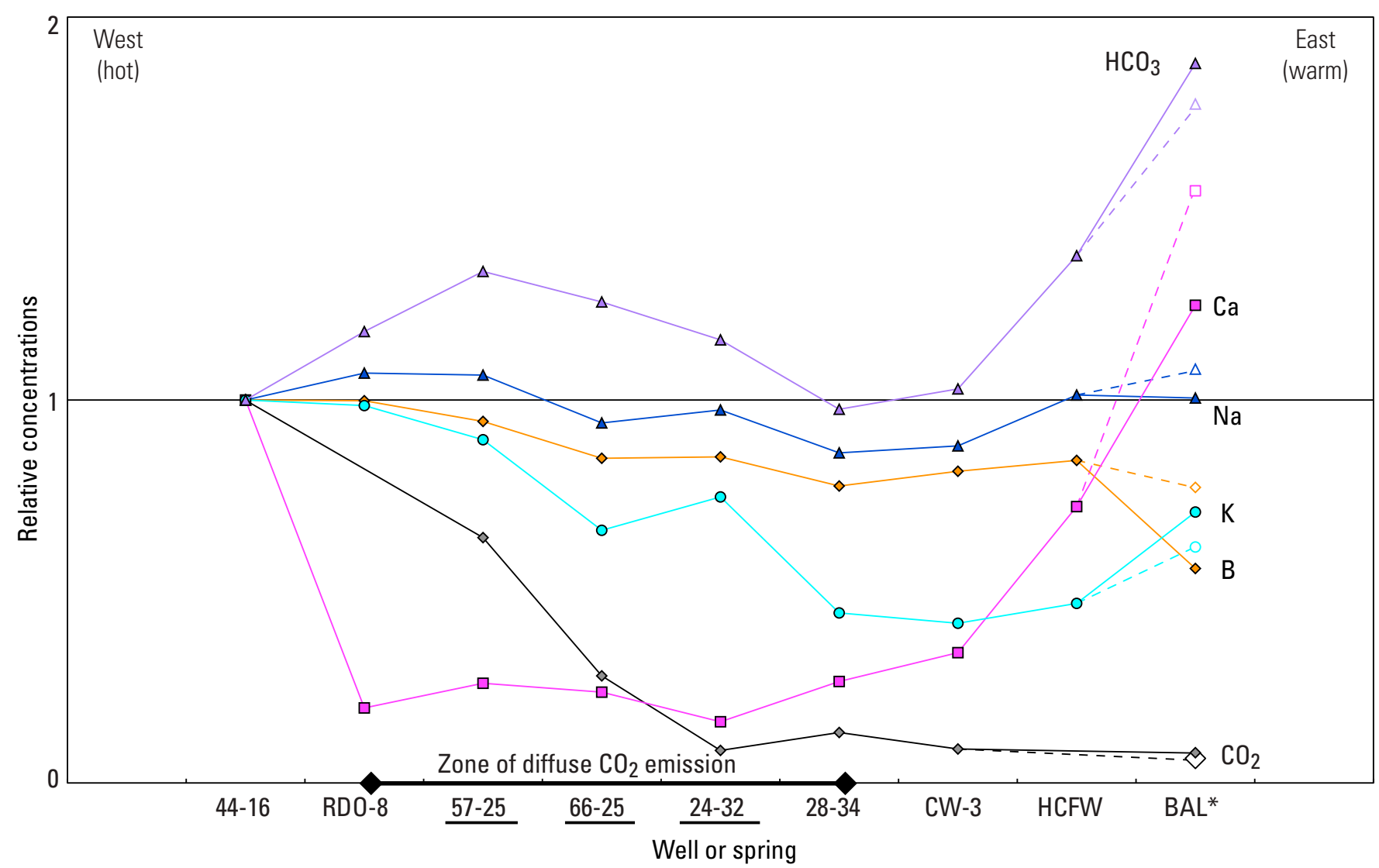

Figure 8. Plot showing changes in several major species during west-to-east flow to the Big Alkali Lake (BAL) spring (filled symbols) or to the Little Hot Creek (LHC) spring (open symbols in the BAL* column. Concentrations of all species from Brown and others (2013) are normalized to the concentrations in well 44-16. See figure 1 for site locations and names.

counterflow of cool water underneath the eastward flowing hot water, proposed by several workers (for example, Shevenell and others, 1987).

White and others (1990) pointed out that these isotope values for $\delta \mathrm{D}$ and $\delta^{18} \mathrm{O}$ are too light to match present-day precipitation even on the eastern caldera rim, and they proposed that the caldera was largely filled with water recharged during colder climatic times of $1.2-1.5 \mathrm{ka}$, when isotopic ratios in precipitation were several per mil lighter. This stored paleowater was considered to be the diluting water. Shevenell and others (1987) found low tritium and low ${ }^{36} \mathrm{Cl}$ values in nearly all of the caldera thermal waters, even ones with $\mathrm{B}$ and $\mathrm{Cl}$ concentrations indicative of $>50$ percent dilution. As a group, the thermal waters did not show any correlation between tritium and ${ }^{36} \mathrm{Cl}$, or between either of these isotopes and conservative chemical species such as $\mathrm{Cl}$ and $\mathrm{B}$, findings that, in general, preclude a young age for the diluting water (Shevenell and others, 1987). Sorey and others (1991) argued that an inverse correlation between tritium and $\mathrm{Cl}$ in fact exists, and that the diluting water is therefore modern. These authors suggest a complex dilution scheme whereby thermal waters west of Casa Diablo are diluted by groundwater that has a $\delta \mathrm{D}$ value near -118 per mil. To account for dilution east of Casa Diablo, they invoke a source external to the caldera, such as Round Valley $\sim 8 \mathrm{~km}$ southeast of the caldera rim.
The four tritium values $>1$ tritium unit (TU) in the dataset of Shevenell and others (1987) are shown on figure 4. The sample with 1.4 TU from well RDO-8 was collected soon after drilling and thought to contain some drilling fluid. The high tritium value (22.3 TU) in the fish hatchery spring ("FH" on fig. 1) demonstrates dilution by local precipitation that recharged after 1953. Only two other thermal features contained tritium at $>1$ TU. Some modern (post-1953) groundwater must be in the mix at these sites, but may not necessarily be a large fraction of the total fluid, given the high tritium values in precipitation in the 1950s-1970s. The inverse relation between tritium and Cl highlighted by Sorey and others (1991, their figure 4) appears to be a case of minor dilution of just a few features by modern groundwater.

The west moat mixing line involving dilute water with a $\delta$ D value near -118 per mil (Sorey and others, 1991, their figure 3) relied on a sample from well 44-16 that was collected using air-lift, a process involving steam loss and possible isotopic fractionation. Figures 3 and 7 show isotopic data for samples from 44-16 (and RDO-8) collected under pressurized conditions. These data show no evidence of a distinct "westmoat" mixing line, and instead are reasonably consistent with dilution by water with a $\delta \mathrm{D}$ value near -135 per mil throughout the hydrothermal system.

Complexities no doubt exist, as suggested by Sorey and others (1991), and probably account for the scatter about 
the mixing lines in figures 3 and 7, as well as the occasional tritium presence (fig. 4), but the general scenario involving a single diluting water, possibly paleo-water, throughout the south moat flow zone (White and others, 1990) seems reasonable. Deep wells in the caldera are typically sampled in the zone of highest temperature, and sampling lower temperature zones that frequently underlie these hot zones could provide isotopic data to resolve this issue. The deep wells that bottom in basement rocks mostly find water temperatures near $100^{\circ} \mathrm{C}$, leading Farrar and others (2003) to speculate that a spatially extensive $\sim 100{ }^{\circ} \mathrm{C}$ convection system circulates within the basement. This convection system could consist predominantly of the water that dilutes the thermal fluid. To refer to this water as "cold" would then be incorrect, and it is likely to be much less dilute than the typical cold groundwater in the region.

\section{Connections Between Hydrothermal Features at Long Valley}

Some early studies (for example, Sorey, 1985) discussed a possible connection between the caldera hydrothermal system and Reds Meadow tub (RMT) warm spring at the western base of Mammoth Mountain (fig. 1), but its low $\mathrm{Cl}$ concentration, high $\mathrm{Ca}$ concentration, and high tritium contents show that this warm spring is an isolated feature with shallow circulation (Shevenell and others, 1987, Sorey and others, 1998). Some warm waters in the east moat were linked by Sorey (1985) to a separate convection system involving recharge on the northeast caldera rim, though temperature modeling by Blackwell (1985) suggests otherwise, and the issue remains unresolved.

A question of some importance to the thermal state of the resurgent dome is whether the hot springs at Little Hot Creek (LHC), a few kilometers north of Hot Creek gorge (fig. 1), are connected to the south moat flow zone. Sorey (1985) speculated that they might be fed by a part of this flow system that passed under the southern edge of the resurgent dome (and see Sorey and others, 1991, their figure 15). Based on newly acquired well-temperature profiles, Hurwitz and others (2010) concluded that flow from Casa Diablo progressed beneath the resurgent dome at least to wells in Fumarole Valley, but could not identify an obvious continuation of this flow in the temperature profiles from wells (13-21, 13-26) farther east on the dome. Temperature anomalies exist in these wells, but they likely reflect fossil fluid flow paths, according to Hurwitz and others (2010). Thus, eastward flow of thermal water beneath the resurgent dome apparently stops at Fumarole Valley, where it is forced to the southeast.

Farrar and others (2003) proposed that the Little Hot Creek (LHC, fig. 1) springs represent a separate flow system that receives recharge on the south caldera rim, flows northward at depth, and is first encountered in LVEW. They also speculated that water-rock interaction at $\sim 150{ }^{\circ} \mathrm{C}$ during flow to LHC accounts for the higher total dissolved solids, boron, and chloride relative to LVEW. The isotopic values in the LVEW fluid match those in precipitation on the south rim (fig. 3), but the fact that LVEW and LHC plot on or near the mixing lines in figures 3, 4, and 7 hardly seems coincidental: the water from the south rim (or any other recharge area) would have to acquire the exact amount of $\mathrm{B}, \mathrm{Cl}$, and ${ }^{18} \mathrm{O}$ to fit on or near these mixing lines, a highly unlikely occurrence. Separate northward flows along isolated north-trending faults (graben faults and splays of the Hilton Creek Fault), as suggested by Farrar and others (2003), could nevertheless supply fluid to both LVEW and LHC without invoking a distinct source of precipitation or heat.

The chemical and isotopic compositions of fluids at LVEW and LHC can be well explained by northward flow of a minor amount of thermal water from the south moat flow zone. Figure 8 shows the changes in water chemistry that occur during west-to-east flow and is analogous to figure $5 C$, except that continued flow to Big Alkali Lake spring (BAL) is represented, and the concentrations of all species are normalized to their concentrations in well 44-16, at the start of the flowpath. Figure 8 highlights the increase in $\mathrm{HCO}_{3}$ and cations $(\mathrm{Na}, \mathrm{K}$, and $\mathrm{Ca}$ ) toward the eastern end of the flowpath, especially in BAL. This increase reflects water-rock interactions and occurs despite continued dilution, as shown by a decrease in B. The composition of the water at LHC is shown as open symbols for comparison with BAL (fig. 8), and the compositional similarity suggests that subsurface flow of thermal water in the Hot Creek area splits to reach both features, as indicated by the thin red arrows in figure 1. Water composition at LVEW can be attributed to comparable changes in chemistry during northward flow of thermal water resembling that in well CW3. Thus, the heat and magmatic He and C in LVEW and LHC likely reflect fluid transport from the south moat flow zone, and do not demonstrate an independent source of heat or magmatic volatiles beneath the resurgent dome at the present time.

\section{An Additional Source of Magmatic Helium}

While all the fluids in the south moat flow zone can be chemically linked to a single source of thermal water derived from a deep reservoir near well 44-16, some additional input of magmatic helium must occur to account for higher ${ }^{3} \mathrm{He} /{ }^{4} \mathrm{He}$ ratios in thermal springs in the eastern part of the flowpath (fig. 9A). Suemnicht and others (2015) suggest that the ${ }^{3} \mathrm{He} /{ }^{4} \mathrm{He}$ ratio in well $44-16$ is a relatively low, $\sim 4 \mathrm{R}_{\mathrm{A}}$, because ${ }^{4} \mathrm{He}$ is readily scavenged from the old metamorphic basement rocks that constitute the deep reservoir and ${ }^{4} \mathrm{He}$ dilutes the magmatic He component. A similar ratio $\left(\sim 4 \mathrm{R}_{\mathrm{A}}\right)$ is characteristic of the thermal fluid as far east as Hot Bubbling Pool (HBP, fig. 1) and LVEW (3.7 $\mathrm{R}_{\mathrm{A}}$ ), giving no indication of additional magmatic $\mathrm{He}$ inputs over this part of the flowpath. The ${ }^{3} \mathrm{He} /{ }^{4} \mathrm{He}$ ratios increase to values of 5-6 $\mathrm{R}_{\mathrm{A}}$ in $\mathrm{HC}, \mathrm{LHC}$, and BAL as the south moat flow zone reaches splays of the Hilton Creek Fault. This fault is a major tectonic feature that could allow magmatic volatiles to migrate upward from great 


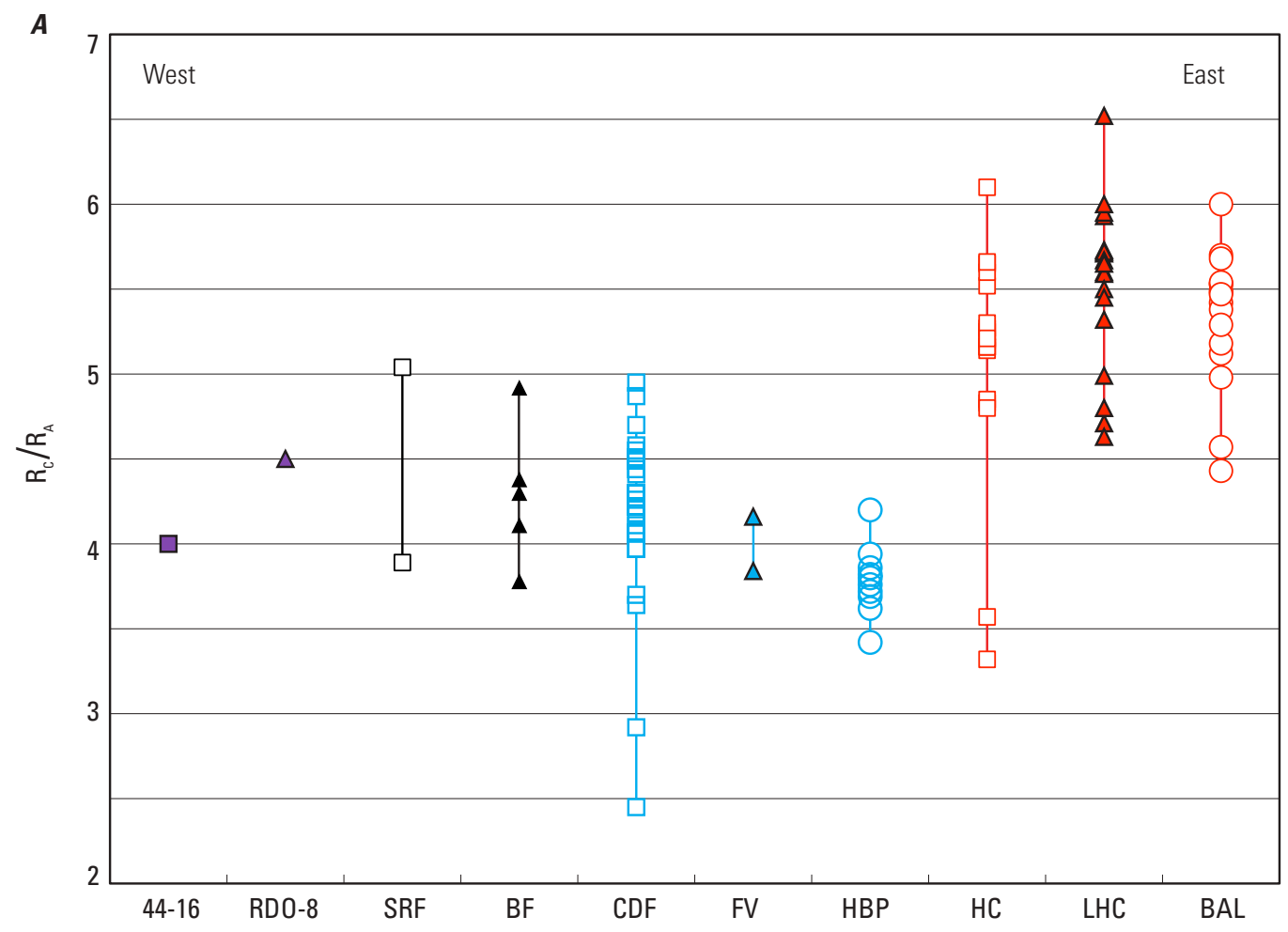

Well or spring

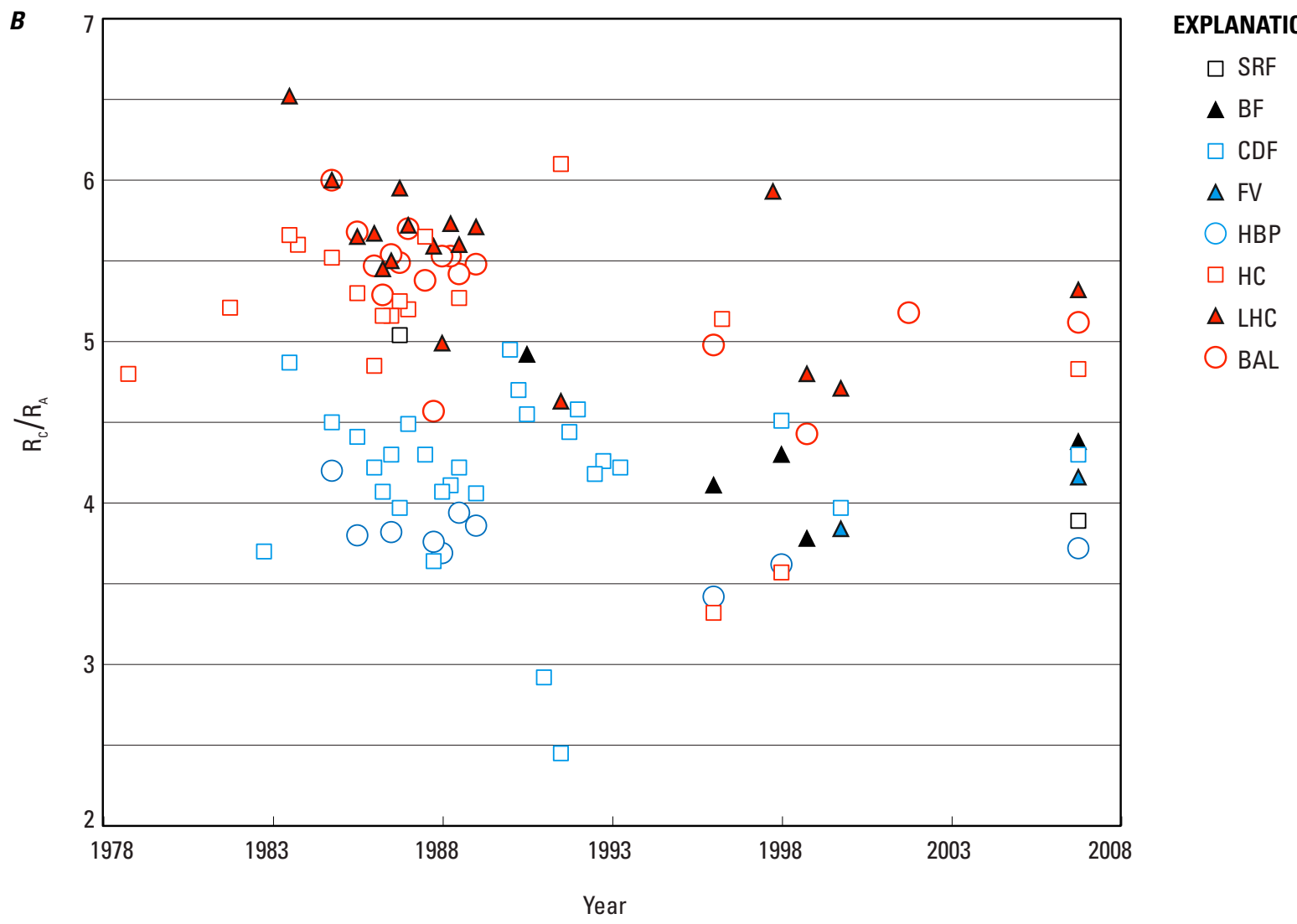

Figure 9. Ratios of ${ }^{3} \mathrm{He} /{ }^{4} \mathrm{He}$ in thermal features (from Suemnicht and others, 2015). Ratios are corrected for air contamination (denoted as $R_{C}$ ) and are expressed in units of $R_{A^{\prime}}$ where $R_{A}$ is the ratio of ${ }^{3} \mathrm{He} /{ }^{4} \mathrm{He}$ in air. " $H C$ " refers to several hot springs in Hot Creek gorge, including HCFW. See figure 1 for site locations and names. $A, R_{C} / R_{A}$ values obtained between 1978 and 2008 at several sites, plotted from west to east. $B, R_{C} / R_{A}$ values from steam vents and hot springs sampled multiple times between 1978 and 2008. 
depth without traversing a high-temperature reservoir hosted in ${ }^{4} \mathrm{He}$-rich basement rocks (Suemnicht and others, 2015).

The lack of evidence for magmatic He inputs to the south moat flow zone west of Hot Creek gorge is curious because geodetic and seismic data are consistent with an inflation source beneath the south moat in the general vicinity of Casa Diablo (Langbein, 2003; Sorey and others, 2003), and Hill and others (2003) attribute a seismic swarm of 1997-1998 in particular to fluid movement associated with this source. Further, water level changes in hot well CW-3, adjacent to HBP, have been attributed to intrusion of magma or magmatic brines to within a few kilometers of the surface in the south moat (Roeloffs and others, 2003). If such events bring magmatic volatiles to the surface, they seem to have little long-term influence on the He isotope distribution in the south moat flow zone. Sampling for He isotopes, however, is relatively infrequent, and short-term responses to seismicity, intrusion, and other perturbations could easily be hidden in the record shown in figure $9 B$.

\section{Geothermal Development}

\section{History of Development and Current Operations}

Geothermal development has focused on the Casa Diablo area, in part to take advantage of the shallow depth of the south moat flow zone at this location. A temperature of $175^{\circ} \mathrm{C}$ could be reached at $<200 \mathrm{~m}$ depth (see the M-1 temperature profile from 1983 in figure 2C). Efficient power generation using water at this temperature requires a binary power plant in which hot water is pumped up and routed through heat exchangers, where the heat is transferred to a working fluid (isobutane) that drives the turbines. The water is kept under pressure throughout the process, preventing loss of gas and steam, and is pumped back into the ground (injected) at a temperature of about $85^{\circ} \mathrm{C}$.

Initial production and injection wells ranged from 125 to $324 \mathrm{~m}$ deep, and the first power plant to come online in January 1985 used $\sim 200 \mathrm{~kg} / \mathrm{s}$ of $175^{\circ} \mathrm{C}$ water to produce 10 MWe (gross) of electric power. Two more plants were added in 1990 to boost the installed capacity to $40 \mathrm{MWe}$ (gross) by using $\sim 850 \mathrm{~kg} / \mathrm{s}$ of hot water. Injection wells were deepened to $\sim 600$ $\mathrm{m}$ to counteract increasing breakthrough of cooled water into the production zone. Thus, the production zone in the early rhyolite was separated from the injection zone in Bishop Tuff by the low-permeability landslide block discussed by Suemnicht and others (2006).

Temperatures in the production zone gradually cooled by $10{ }^{\circ} \mathrm{C}$ or so during the years of production (EGS, Inc., 2012). In 2006, the geothermal plant began to pipe in water from two new wells, 57-25 and 66-25, located $3 \mathrm{~km}$ west of Casa Diablo in Basalt Canyon (fig. 1). Water at $\sim 180^{\circ} \mathrm{C}$ from these wells is mixed into the flow stream to support the needed temperature and supply rate for efficient power production; all injection presently occurs at Casa Diablo. More geothermal wells proposed for Basalt Canyon would increase power production by tens of MWe. Under current plans, additional water produced from Basalt Canyon wells will be piped back and injected there.

\section{Changes Associated with Development}

Withdrawal of fluid from the shallow aquifer at Casa Diablo led to drawdown in water levels and local subsidence of the ground surface, as discussed in detail by Howle and others (2003). Subsidence near the production wellfield was attributed by Sorey and others (1993b) to compaction within and above the production zone, as well as cooling-induced contraction in the injection zone (see the 1991 M-1 temperature profile in figure 2C). By 1997, subsidence totaled $31 \mathrm{~cm}$ at Casa Diablo relative to the surrounding area and spread to the faults that bound the wellfield (Howle and others, 2003). High-Cl hot springs at Casa Diablo disappeared and were replaced by steam vents within the first year of production (Sorey and others, 1993b), and these steam vents became more vigorous in 1991 as pumping from production wells and the depth of injection were increased. As of 2000, the water level in the production zone at Casa Diablo had declined by $\sim 30 \mathrm{~m}$ relative to pre-1991 conditions, but continued rates of decline were small, suggesting stabilization of the system (Howle and others, 2003).

Steam upflow, enhanced by water level drawdown and induced boiling, caused ground heating at the power plant and resulted in the closure of certain areas and facilities. Zones of hot ground and dying vegetation spread away from the power plant along faults of various orientations (Howle and others, 2003). Areas of vegetation kill eventually spread a few kilometers east and west of Casa Diablo in a band overlying the south moat flow zone (fig. 1). Interestingly, patches of thermal ground spread over the ridge from Casa Diablo to Fumarole Valley, but did not continue farther east. Gas boiled out of the thermal fluid accompanied the steam, and diffuse emissions of $\mathrm{CO}_{2}$ were detected and monitored in the vegetation-kill areas by Bergfeld and others (2006). The total diffuse emission of $\mathrm{CO}_{2}$ ( $\sim 24$ metric tons/day) could explain about half of the decrease in $\mathrm{CO}_{2}$ concentration in well fluids along this part of the flowpath (fig. $5 \mathrm{C}$ ). Additional areas of $\mathrm{CO}_{2}$ emission likely escape detection.

Fluid withdrawal from the two Basalt Canyon wells beginning in 2006, with concomitant injection of that fluid at Casa Diablo, led to an immediate water level rise in wells near the plant and in downgradient wells to the east, including well 28-34 (EGS, Inc., 2012). Over time, some vegetation in areas near the power plant appeared to recover/reestablish. However, water levels declined in Basalt Canyon near the new producing wells (EGS, Inc., 2012), and local vegetation kills expanded (Bergfeld and Evans, 2011).

While these local impacts of development have been obvious, impacts in the far field, other than water level 


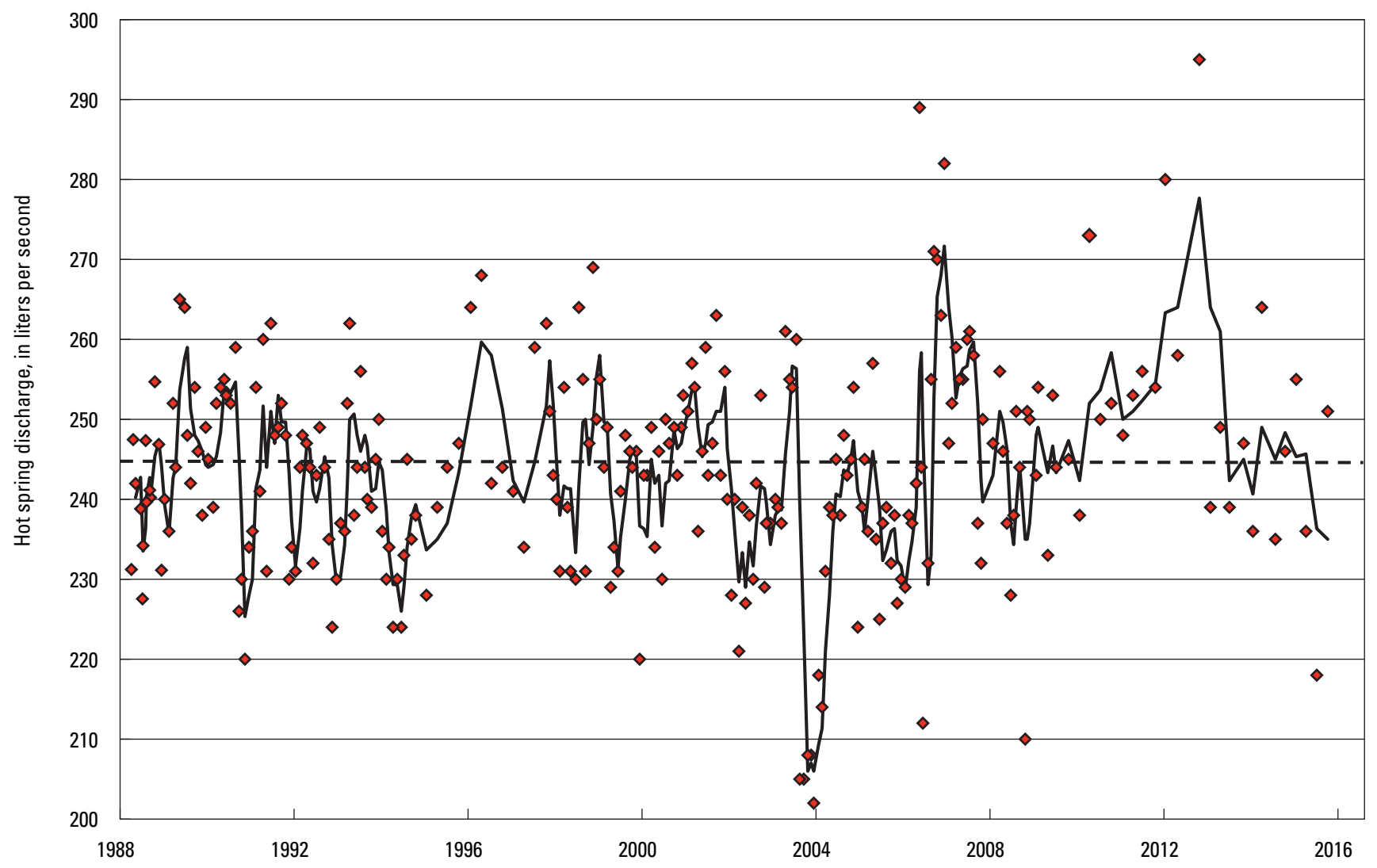

Figure 10. Plot of total hot spring discharge (red diamonds) in Hot Creek gorge between 1988 and 2016, as determined from the increase in boron and chloride concentration at a streamflow gage below the springs compared to an upstream gage (Jim Howle, written commun., 2016). Solid line is a three-point running average, and dashed line shows median value of 245 liters per second for the period of record.

changes in some thermal wells and in Hot Bubbling Pool (HBP), have been hard to demonstrate. Hurwitz and others (2010) found slight temperature decreases over time in the Fumarole Valley wells that could plausibly reflect heat extraction at Casa Diablo, but transient temperature increases have also been observed in other wells like CH-10B. Flowtemperature relations in the Fish Hatchery spring (FH) have changed with time (Sorey and others, 1993b), but distinguishing the effect of geothermal development is difficult given that climate/precipitation characteristics or even seismic unrest may be the main drivers behind some of the changes (Sorey and Sullivan, 2006). Some hot springs in Hot Creek gorge suddenly began to geyser in 2006, but this activity predated the startup of the Basalt Canyon wells and could not be related to any obvious human-induced cause (Farrar and others, 2007). The total discharge of the hot springs in Hot Creek gorge has been monitored for nearly the entire period of geothermal development and appears to show only small random variations about a mean value of $245 \mathrm{~L} / \mathrm{s}$ (fig. 10).

\section{Future Monitoring}

In the early days of geothermal development at Casa Diablo, a hydrologic monitoring program was put into place to detect negative effects such as declines in the thermal water component in the Fish Hatchery springs (FH, fig. 1) or in the vigor and scenic quality of the springs in Hot Creek gorge. With planned wellfield expansion, this monitoring will certainly continue. For example, geothermal consultants estimate a 17 percent decline in the thermal water supply to the Fish Hatchery springs (EGS, Inc., 2012), but, given that these springs apparently respond in a complex way to several drivers (Sorey and Sullivan, 2006), the actual effects of wellfield expansion can only be verified through measurement. Additional monitoring is also needed. The Basalt Canyon area is close to the town of Mammoth Lakes and is partially within the town's groundwater basin. Although the Mammoth Community Water District (MCWD) obtains its groundwater from supply wells several kilometers southwest of Basalt Canyon, thermal water is known to underlie the northwestern part of the groundwater basin where some of these supply wells are located. At least one MCWD supply well (P17, fig. 1) appears to contain about 2 percent thermal water, based on elevated B and $\mathrm{Cl}$ concentrations of 0.23 and $5.2 \mathrm{mg} / \mathrm{L}$, respectively, and a level of As that exceeds the standard for domestic use (Mammoth Community Water District, 2005).

The increased production from Basalt Canyon is planned to be balanced by proximal injection, in theory buffering water 
levels against major changes. However, a production/injection scheme that provides adequate pressure support for production wells without rapid breakthrough of injectate usually requires some trial and error, and can be difficult to achieve. The MCWD is concerned that a water level rise in the production zone could increase the amount of arsenic and other unwanted constituents in their supply wells. A water level drop could draw shallow groundwater down into the thermal zone and result in reduced supply. Under present conditions, the isotopic data (fig. 3) show no evidence for western caldera groundwater mixing into the thermal fluid, but potential connectivity between thermal and overlying cold groundwater cannot be ruled out. To obtain evidence of problematic changes in water level or chemistry at an early state, new multi-level monitoring wells have been drilled between Basalt Canyon and the MCWD supply wells.

Geothermal consultants consider a small, additional water level drop of a few meters to be the most likely outcome of increased production from Basalt Canyon, and predict minimal impacts (EGS, Inc., 2012). However, steam and gas upflow already occurs in the Basalt Canyon area, and any further water level drawdown could lead to increased upflow, with the possible development of new vegetation kills or objectionable diffuse emission of low concentrations of $\mathrm{H}_{2} \mathrm{~S}$ in a populated area. Ground-based monitoring of soil temperatures and diffuse gas emissions will continue into the future, and a program to identify heated ground from the air using nighttime thermal infrared imagery has been put into place for the early stages of wellfield production (Bergfeld and others, 2015b).

\section{Summary}

Recent data and analysis continue to support the general model of the Long Valley Caldera hydrothermal system as delineated by Sorey and others (1991). Below is a synthesis of the model that includes aspects from other works (for example, from Farrar and others, 2003; Hurwitz and others, 2010; Brown and others, 2013; Suemnicht and others, 2015) and inferences from the data and discussion above. This synthesis describes the hydrothermal system in its pre-development state (except as noted) and is probably applicable to most of the past 40,000 years, even though variations in some of the parameters (flow rates, temperatures, aquifer depths) and specific features (spring vents) are certain to have occurred over this time.

Snowmelt on the west rim of the caldera infiltrates to several kilometers depth and feeds into a hydrothermal reservoir in permeable basement rocks beneath the west moat. Heat and magmatic volatiles are acquired from deep basaltic intrusions that appear to have rejuvenated the northwestern edge of the Long Valley silicic magma chamber. Residence time in the reservoir is sufficiently long (centuries?) that mineral equilibration at $\sim 220^{\circ} \mathrm{C}$ is achieved, a positive oxygen isotope shift of $\sim 1.5$ per mil occurs, and enough radiogenic ${ }^{4} \mathrm{He}$ is leached from the rocks to dilute the magmatic ${ }^{3} \mathrm{He}$ and yield $a^{3} \mathrm{He} /{ }^{4} \mathrm{He}$ ratio of $\sim 4 \mathrm{R}_{\mathrm{A}}$. Nearly all of the boron and chloride that discharge from the Long Valley hydrothermal system are acquired at this time from an unknown mix of basement and magmatic sources.

Upflow from the reservoir occurs in the west moat near well 44-16, probably just south of the well, where major normal faults intersect and provide a flowpath. The $370 \mathrm{~kg} / \mathrm{s}$ upflow encounters permeable zones within the volcanic fill and flows eastward through the south moat, with most of the water discharging from boiling springs in Hot Creek gorge some $15 \mathrm{~km}$ away. Flow velocity in this "south moat flow zone" is so rapid ( $\geq 400 \mathrm{~m} / \mathrm{yr}$ ) that the water can only partially re-equilibrate with aquifer minerals, and leaching of additional $\mathrm{B}, \mathrm{Cl}$, and ${ }^{4} \mathrm{He}$ is insignificant. Dilution from below by non-thermal water that is isotopically very light, and possibly a paleo-water, occurs over the entire flow path. Some of the dissolved gases (mostly $\mathrm{CO}_{2}$ ) and steam escape west of Casa Diablo as the land surface drops, and decreasing depth to water allows some boiling to occur. However, the chemical and isotopic data from wells and springs can be satisfactorily explained without invoking any other water or gas sources, beyond some young (tritiated) groundwater in a few features, until the flow zone reaches the east moat.

A distinctive increase in ${ }^{3} \mathrm{He} /{ }^{4} \mathrm{He}$ ratios by about $1 \mathrm{R}_{\mathrm{A}}$ in features HCFW and BAL in the east moat (fig. 1) suggests that magmatic gases flow up from depth through splays of the Hilton Creek Fault. A high ${ }^{3} \mathrm{He} /{ }^{4} \mathrm{He}$ ratio in LHC and water chemistry comparisons suggest that this feature is fed by minor northward flow of thermal water from the vicinity of Hot Creek gorge, following a splay of the Hilton Creek Fault. No separate source of heat and magmatic gas beneath the resurgent dome is required to explain the chemistry and ${ }^{3} \mathrm{He} /{ }^{4} \mathrm{He}$ ratio in LHC. Similarly, fault-controlled northward flow of a small amount of thermal water from the Fumarole Valley or HBP area may feed into the deep fluid encountered in LVEW.

Geothermal development has led to local land-surface subsidence and increased boiling in the vicinity of production wells, and this, in turn, has led to new areas of hot ground, diffuse degassing, and vegetation kill. Significant effects far from the wellfield have not been demonstrated, but rapid hydrologic connections through most of the south moat flow zone have been demonstrated by correlated water level changes in thermal wells and tracer (isobutane) transport results. Proposed additional geothermal power development will need to be monitored to mitigate any potential adverse impacts, such as altered spring flows, increased steam upflow, gaseous emissions, and vegetation kill zones. 


\section{References}

Bailey, R.A., 1989, Geologic map of Long Valley Caldera, Mono-Inyo Craters volcanic chain, and vicinity, Mono County, California: U.S. Geological Survey Miscellaneous Investigations Map I-1933, scale 1:62,500.

Bailey R. A., Dalrymple G. B., Lanphere M. A., 1976, Volcanism, structure and geochronology of the Long Valley caldera, Mono County, California. Journal of Geophysical Research, v. 81, p. 725-744.

Bergfeld, D., Evans, W.C., 2011, Monitoring $\mathrm{CO}_{2}$ emissions in tree kill areas near the resurgent dome at Long Valley Caldera, California: U.S. Geological Survey Scientific Investigations Report 2011-5038, 22 p.

Bergfeld, D., Evans, W.C., Howle, J.F., Hunt, A.G., 2015a, Magmatic gas emissions at Holocene volcanic features near Mono Lake, California, and their relation to regional magmatism: Journal of Volcanology and Geothermal Research, v. 292 , p. $70-83$.

Bergfeld, D., Evans, W.C., Howle, J.F., Farrar C.D., 2006, Carbon dioxide emissions from vegetation-kill zones around the resurgent dome of Long Valley Caldera, eastern California, USA: Journal of Volcanology and Geothermal Research, v. 152, no. 1-2, p. 140-156.

Bergfeld, D., Vaughan, R.G., Evans, W.C., Olsen, E., 2015b, Monitoring ground-surface heating during expansion of the Casa Diablo production well field at Mammoth Lakes, California: Geothermal Resources Council Transactions, v. 39, p. 1007-1013.

Blackwell, D.D., 1985, A transient model of the geothermal system of the Long Valley caldera, California: Journal of Geophysical Research, v. 90, no. B13, p. 11,229-11,241.

Brown, S.T., Kennedy, B.M., DePaolo, D.J., Hurwitz, S., Evans, W.C., 2013, Ca, Sr, O and D isotope approach to defining the chemical evolution of hydrothermal fluids: example from Long Valley, CA, USA: Geochimica et Cosmochimica Acta, v. 122, p. 209-225.

Bursik, M., Sieh, K., 1989, Range front faulting and volcanism in the Mono Basin, eastern California: Journal of Geophysical Research, v. 94, no. B11, p. 15,587-15,609.

Bursik, M., Renshaw, C., McCalpin, J., Berry, M., 2003, A volcanotectonic cascade: activation of range front faulting and eruptions by dike intrusion, Mono Basin-Long Valley Caldera, California: Journal of Geophysical Research, v. 108, no. B8, http://dx.doi.org/10.1029/2002JB002032.

Craig, H., 1961, Isotopic variations in meteoric waters: Science, v. 133, p. 1702-1703.
EGS, Inc., 2012, Technical geologic overview of Long Valley Caldera for the Casa Diablo IV geothermal development project, Appendix D, http://www.blm.gov/style/medialib/ blm/ca/pdf/bishop/casa_diablo_40.Par.26444.File.dat/cd4_ final_eir_volume_2_appendices_a-f.pdf.

Eichelberger, J.C., Vogel, T.A., Younker, L.W., Miller, C.D., Heiken, G.H., Wohletz, K.H., 1985, Structure and Stratigraphy beneath a young phreatic vent: South Inyo Crater, Long Valley Caldera, California: Journal of Geophysical Research, v. 93, no. B11, p. 13,208-13,220.

Evans, W.C., Hurwitz, S., Bergfeld, D., Lewicki, J.L., Huebner, M.A., Williams, C.F., Brown, S.T., 2013, Water-rock interaction in the Long Valley Caldera (USA): Procedia Earth and Planetary Science, v. 7, p. 252-255, doi: 10.1016/j.proeps.2013.03.186.

Evans, W.C., Lorenson, T.D., Sorey, M.L., Bergfeld, D., 2004, Transport of injected isobutane by thermal groundwater in Long Valley Caldera, California, USA, in Wanty, R.B. and Seal II, R.R. eds., Water-Rock Interaction-11, Saratoga Springs, Balkema, p. 125-129.

Farrar, C., DeAngelo, J., Clor, L., Murphy, F., Williams, C., Grubb, F., and Hurwitz, S., 2010, Temperature data from wells in Long Valley Caldera, California (ver. 2.0, January 2015): U.S. Geological Survey Data Series 523, http://pubs. usgs.gov/ds/523/.

Farrar, C.D., Evans, W.C., Venezky, D.Y., Hurwitz, S., Oliver, L.K., 2007, Boiling water at Hot Creek - the dangerous and dynamic thermal springs in California's Long Valley Caldera: U.S. Geological Survey Fact Sheet 2007-3045, 4p.

Farrar, C.D., Sorey, M.L., Roeloffs, E.R., Galloway, D.L., Howle, J.F., Jacobsen, R., 2003, Inferences on the hydrothermal system beneath the resurgent dome in Long Valley caldera, east-central California, USA, from pumping tests and geochemical sampling: Journal of Volcanology and Geothermal Research, v. 127, p. 305-328.

Fischer, M., Roller, K., Kuster, M., Stockhert, B., McConnell, V.S., 2003. Open fissure mineralization at $2600 \mathrm{~m}$ depth in Long Valley exploratory well (California) - insight into the history of the hydrothermal system: Journal of Volcanology and Geothermal Research, v. 127, p. 347-363.

Fournier, R.O., Sorey, M.L., Mariner, R.H., Truesdell, A.H., 1979 , Chemical and isotopic prediction of aquifer temperatures in the geothermal system at Long Valley, California: Journal of Volcanology and Geothermal Research, v. 5, p. 17-34.

Goff F., Wollenberg H. A., Brookins D. C., Kistler R. W., 1991, A Sr-Isotopic comparison between thermal waters, rocks and hydrothermal calcites, Long Valley caldera, California: Journal of Volcanology and Geothermal Research, v. 48 , p. $265-281$. 
Goff, F., Shevenell, L., Gardner, J.N., Vuataz, F.-D., Grigsby, C.O., 1988, The hydrothermal outflow plume of Valles Caldera, New Mexico, and a comparison with other outflow plumes: Journal of Geophysical Research, v. 93, no. B6, p. 6041-6058.

Healy, J., Hochstein, M.P., 1973, Horizontal flow in hydrothermal systems: Journal of Hydrology (New Zealand): v. 12, p. 71-82.

Hildreth, W., Fierstein, J., Champion, D., Calvert, A., 2014, Mammoth Mountain and its mafic periphery - A late Quaternary volcanic field in eastern California: Geosphere, v. 10, p. 1315-1365.

Hildreth, W., 2004, Volcanological perspective on Long Valley, Mammoth Mountain, and Mono Craters: several contiguous but discrete systems: Journal of Volcanology and Geothermal Research, v. 136, p. 169-198.

Hill, D.P., Langbein, J.O., Prejean, S., 2003, Relations between seismicity and deformation during unrest in Long Valley Caldera, California, from 1995 through 1999: Journal of Volcanology and Geothermal Research, v. 127, p. 175-193.

Hill, D.P., Bailey, R.A., Ryall, A.S., 1985, Active tectonic and magmatic processes beneath Long Valley caldera, eastern California: an overview: Journal of Geophysical Research, v. 90 , p. $11,111-11,120$.

Hilton, D.R., 1996, The helium and carbon isotope systematics of a continental geothermal system: results from monitoring studies at Long Valley Caldera (California, U.S.A.): Chemical Geology, v. 127, p. 269-295.

Howle, J.F., Langbein, J.O., Farrar, C.D., Wilkinson, S.K., 2003, Deformation near the Casa Diablo geothermal well field and related processes Long Valley caldera, Eastern California, 1993-2000: Journal of Volcanology and Geothermal Research, v. 127, p. 365-390.

Hurwitz S., Farrar C. D., Williams C. F., 2010, The Thermal regime in the resurgent dome of Long Valley Caldera, California-Inferences from precision temperature logs in deep wells: Journal of Volcanology and Geothermal Research, v. 198, p. 233-240.

Ingebritsen, S. E., Sorey, M. L., 1985, A quantitative analysis of the Lassen hydrothermal system, north-central California: Water Resources Research, v. 21, p. 853-868.

Kharaka, Y.K., Gunter, W.D., Aggarwal, P.K., Perkins, E.H., DeBraal, J.D., 1988, SOLMINEQ.88: A Computer Program for Geochemical Modeling of Water-Rock Interactions: U.S. Geological Survey Water Resources Investigations Report $88-4227,420$ p.
Lachenbruch, A.H., Sass, J.H., Munroe, R.J., Moses Jr., T.H., 1976a, Geothermal setting and simple heat conduction models for the Long Valley caldera: Journal of Geophysical Research, v. 81, no. 5, p. 769-784.

Lachenbruch, A.H., Sorey, M.L., Lewis, R.E., Sass, J.H., 1976b, The near-surface hydrothermal regime of Long Valley caldera: Journal of Geophysical Research, v. 81, p. 763-768.

Langbein, J.O., 2003, Deformation of the Long Valley caldera, California: inferences from measurements from 1988 to 2001: Journal of Volcanology and Geothermal Research, v. 127 , p. 247-267.

Mammoth Community Water District, 2005, Groundwater management plan for the Mammoth Basin watershed: http:// www.mcwd.dst.ca.us/assets/final-gwmp.pdf

Mariner, R.H., Willey, L.M., 1976, Geochemistry of thermal waters in Long Valley, Mono County, California: Journal of Geophysical Research, v. 81, no. 5, p. 792-800.

Martini, B.A., 2002, New insights into the structural, hydrothermal and biological systems of Long Valley caldera using hyperspectral imaging: PhD Thesis, University of California Santa Cruz, 291 p.

McConnell V. S., Valley J. W., Eichelberger J. C., 1997, Oxygen Isotope composition of intracaldera rocks: hydrothermal history of the Long Valley Caldera, California: Journal of Volcanology and Geothermal Research, v. 76, p. 83-109.

Muffler, L.J.P., Williams, D.L., 1976, Geothermal investigations of the U.S. Geological Survey in Long Valley, California, 1972-1973: Journal of Geophysical Research, v. 81, p. 721-724.

Peacock, J.R., Mangan, M.T., McPhee, D., Wannamaker, P.E., 2016, Three-dimensional electrical resistivity model of the hydrothermal system in Long Valley Caldera, California, from magnetotellurics: Geophysical Research Letters, v. 43, p. 7953-7962.

Reid, M.R., Coath, C.D., Harrison, T.M., McKeegan, K.D., 1997, Prolonged residence times for the youngest rhyolites associated with Long Valley Caldera: ${ }^{230} \mathrm{Th}-{ }^{238} \mathrm{U}$ ion microprobe dating of young zircons: Earth and Planetary Science Letters, v. 150, p. 27-39.

Roeloffs, E., Sneed, M., Galloway, D.L., Sorey, M.L., Farrar, C.D., Howle, J.F., Hughes, J., 2003, Water-level changes induced by local and distant earthquakes at Long Valley caldera, California: Journal of Volcanology and Geothermal Research, v. 127, p. 269-303. 
Shevenell, L., Goff, F., Grigsby, C.O., Janik, C.J., Trujillo Jr., P.E., Counce, D., 1987, Chemical and isotopic characteristics of thermal fluids in the Long Valley caldera lateral flow system, California: Geothermal Resources Council Transactions, v. 11, p. 195-201.

Shigeno, H., 1986, Chemical indications of a deep hydrothermal system in metasedimentary rocks in Long Valley caldera, California: in Sorey, M.L., Farrar, C.D., and Wollenberg, H.A., eds. Proceedings of the Second Workshop on Hydrologic and Geochemical Monitoring in the Long Valley Caldera, July 15-17, 1986. Lawrence Berkeley Laboratory, Report LBL-22852, p. 34.

Smith, G.I., 1976, Origin of lithium and other components in the Searles Lake evaporates, California: U.S. Geological Survey Professional Paper 1005, p. 92-103.

Sorey, M.L., 1985, Evolution and present state of the hydrothermal system in Long Valley caldera: Journal of Geophysical Research, v. 90, no. B13, p. 11,219-11,228.

Sorey, M.L., Evans, W.C., Kennedy, B.M., Farrar, C.D., Hainsworth, L.J., Hausback, B., 1998, Carbon dioxide and helium emissions from a reservoir of magmatic gas beneath Mammoth Mountain, California: Journal of Geophysical Research, v. 103, no. B7, p. 15303-15323.

Sorey, M.L., Farrar, C.D., Marshall, G.A., 1993b, Hydrologic and topographic changes in Long Valley caldera, California, induced by geothermal development 1985-1992: Proceedings 15th New Zealand Geothermal Workshop 1993, p. 149-154.

Sorey, M.L., Kennedy, B.M., Evans, W.C., Farrar, C.D., Suemnicht, G.A., 1993a, Helium isotope and gas discharge variations associated with crustal unrest in Long Valley Caldera, California, 1989-1992: Journal of Geophysical Research, v. 98, no. B9, p. 15871-15889.

Sorey, M.L., McConnell, V.S., Roeloffs, E., 2003, Summary of recent research in Long Valley Caldera, California: Journal of Volcanology and Geothermal Research, v. 127, p. 165173 .

Sorey, M.L., Suemnicht, G.A., Sturchio, N.C., Nordquist, G.A., 1991, New evidence on the hydrothermal system in Long Valley Caldera, California, from wells, fluid sampling, electrical geophysics, and age determinations of hot-spring deposits: Journal of Volcanology and Geothermal Research, v. 48 , p. 229-263.

Sorey, M.L., Sullivan, R., 2006, Quantitative analyses of warm spring waters at the Hot Creek Fish Hatchery, Mammoth Lakes, California: Geothermal Resources Council Transactions, v. 30, p. 947-951.
Spycher, N., Peiffer, L., Sonnenthal E., 2014, GeoT user's guide, A computer program for multicomponent geothermometry and geochemical speciation, version 1.5: Lawrence Berkeley National Laboratory Report 6172E (revised), http://esd.lbl.gov/technology/geot/.

Suemnicht, G.A., Kennedy, B.M., Evans, W.C., 2015, Helium isotope systematics of Long Valley Caldera, California: Proceedings World Geothermal Congress 2015, Melbourne Australia, 19-25 April 2015, http:/www.geothermal-energy. org/pdf/IGAstandard/WGC/2015/14014.pdf.

Suemnicht, G.A., Sorey, M.L., Moore, J.N., Sullivan, R., 2006, The shallow hydrothermal system of Long Valley caldera: Geothermal Resources Council Transactions, v. 30, p. 465-469.

Suemnicht, G.A., Varga, R.J., 1988, Basement structure and implications for hydrothermal circulation patterns in the western moat of Long Valley caldera, California: Journal of Geophysical Research, v. 93, no. B11, p. 13191-13207.

Tempel R. N., Sturmer D. M., Schilling J., 2011, Geochemical modeling of the near-surface hydrothermal system beneath the southern moat of Long Valley Caldera, California: Geothermics, v. 40, p. 91-101.

Varga, R.J., Bailey, R.A., Suemnicht, G.A., 1990, Evidence for 600- year-old basalt and magma mixing at Inyo Craters volcanic chain, Long Valley, California: Journal of Geophysical Research, v. 95, no. B13, p. 21441-21450.

Vazquez, J.A., Lidzbarski, M.I., 2012, High-resolution tephrochrononolgy of the Wilson Creek Formation (Mono Lake, California) and Laschamp event using ${ }^{238} \mathrm{U}-{ }^{230} \mathrm{Th}$ SIMS dating of accessory mineral rims: Earth and Planetary Science Letters, v. 357-358, p. 54-67.

White A. F., Peterson M. L., 1991, Chemical equilibrium and mass balance relationships associated with the Long Valley hydrothermal system, California, USA: Journal of Volcanology and Geothermal Research, v. 48, p. 283-302.

White, A.F., Peterson, M.L., Wollenberg, H., and Flexser, S., 1990, Sources and fractionation processes influencing the isotopic distribution of $\mathrm{H}, \mathrm{O}$, and $\mathrm{C}$ in the Long Valley hydrothermal system, California, USA: Applied Geochemistry v. 5, p. 571-585. 

Menlo Park Publishing Service Center, California

Manuscript approved April 21, 2017

Edited by Claire Landowski

Design and layout by Vivian Nguyen 


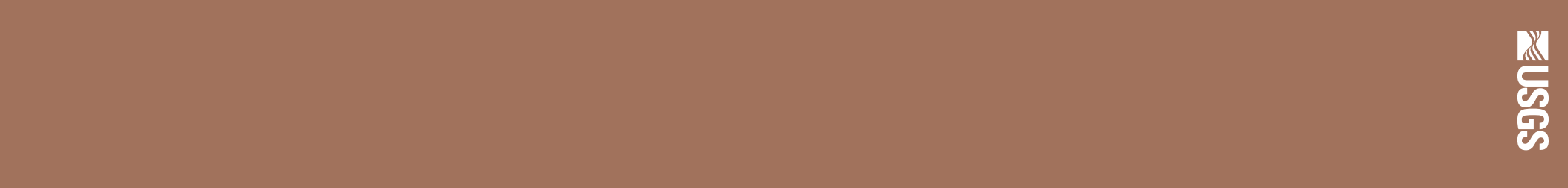

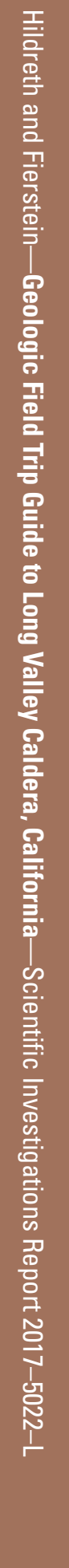

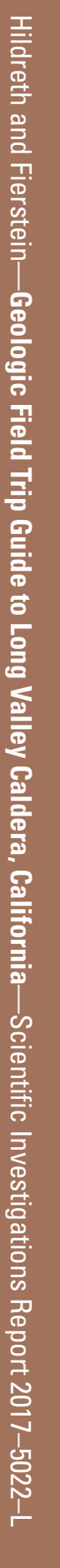
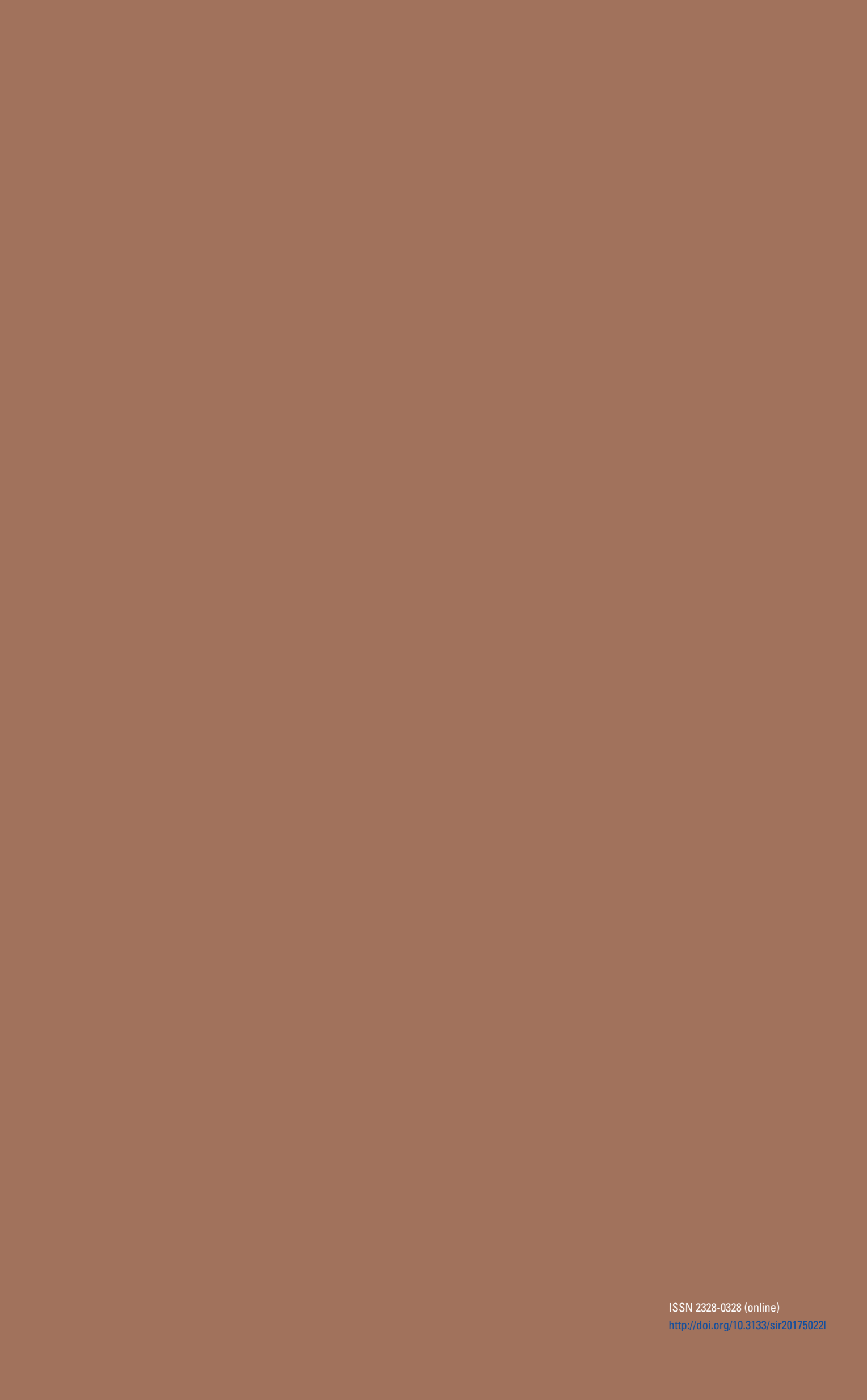

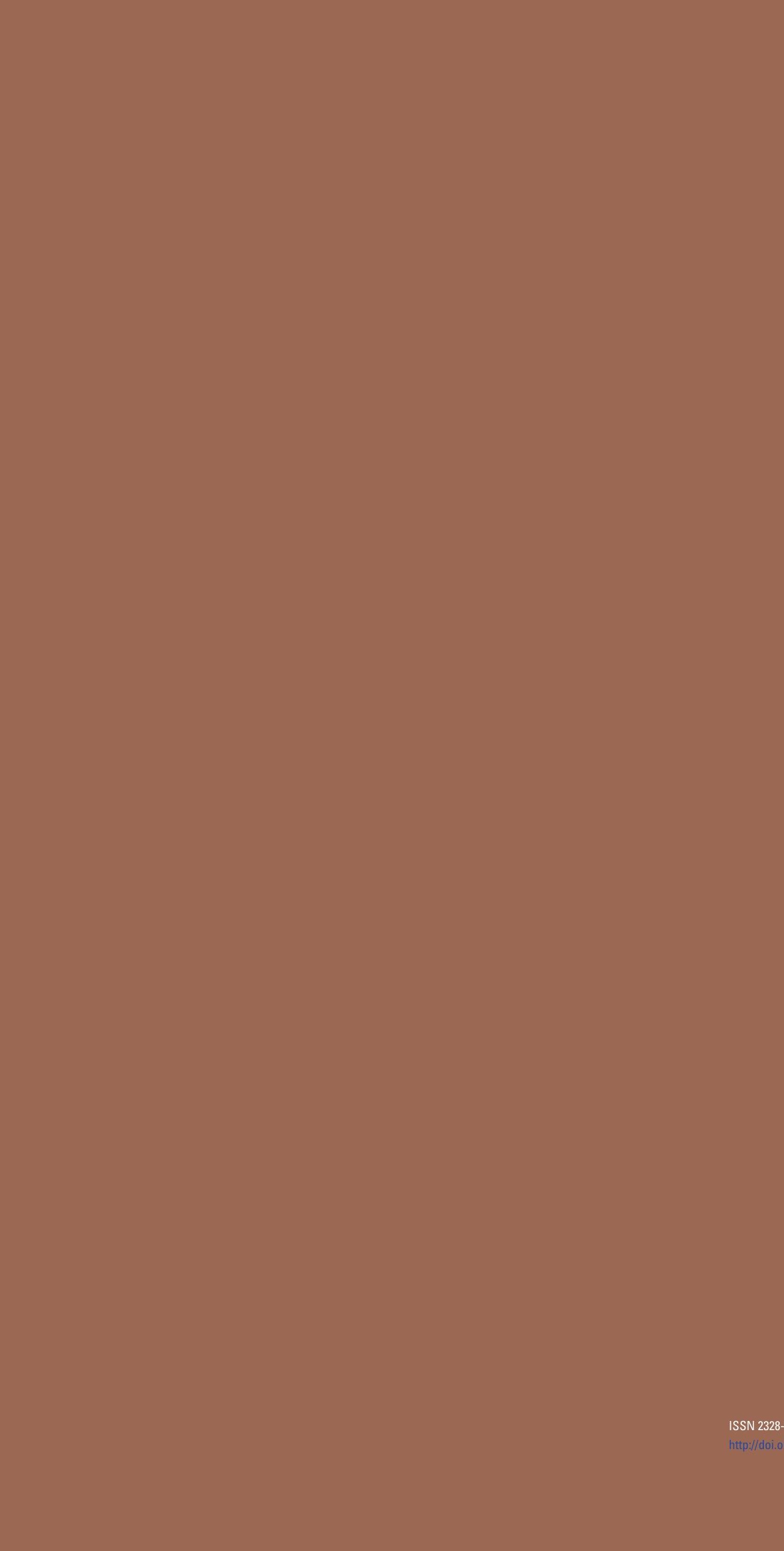

ISSN 2328-0328 (online) 